THE DRESS

\title{
OF WORDS
}

Essays on Restoration and

Eighteenth Century Literature

in Honor of

RICHMOND P. BOND

Edited by Robert B. White, Jr.

University of Kansas Libraries 
University of Kansas Publications

Library Series, 42 
"Condemned to Petticoats"

(C) 1978 by Robert Halsband

All other material

(C) 1978 by the University of Kansas Libraries.

Printed by the University of Kansas Printing Service, Lawrence, Kansas, U.S.A. 
For

Richmond P. Bond

teacher, scholar, critic, and friend

in whose honor

these essays

have been written

and collected 


\section{Contents}

ENGLISH LITERATURE AND CULTURE

Samson Agonistes: Justice and Reconciliation

by FREDSON BOwERS

The Subscription List for Pope's lliad, 1715

25

by MatTHEW J. C. HodgarT

"Condemned to Petticoats": Lady Mary Wortley Montagu

as Feminist and Writcr

35

by RoBert HalsBand

"A Turn of Thinking": Benjamin Franklin, Cotton Mather,

and Daniel Defoe on "Doing Good"

53

by GILBERT D. McEwEN

Man and Yahoo: Dialectic and Symbolism in Gulliver's

"Voyage to the Country of the Houyhnlnnms"

by JAMES E. GILE

Dr. Johnson and Cookery

by Giles Barber

Antisentimentalism in Goldsmith's The Good Natur'd Man:

The Limits of Parody

105

by Oliver W. Fencuson

A House Party at Stowe

by W. S. Lewis

Harlequin Intrudes: William Cowper's Venture into the Satiric Mode .... by Lodwick HARTLEY

127

\section{THE PERIODICAL}

The Contributions of Abel Boyer as Whig Journalist

and Writer of the Protestant Post-Boy

by HeNRY L. SNYDER

Dunton's Post-Angel: Messenger of Remarkable Providences

151

by ANNTEEL JENKINS

Steele and his Answerers: May 1709-February 1714

by Edward A. Bloom and Lillian D. Bloom

"A Truly Elegant Work": The Contemporary Reputation of

Hawkesworth's Adventurer

by Philip Makone Griffith

A Latc-Century Spectatorial Essayist and His Personae

by EDWARD P. WhLLEY

List of Contributors 


\section{Samson Agonistes: Justice and Reconciliation}

By Fredson Bowers

In his first invocation to the muse in Paradise Lost, and again in subsequent invocations, Milton quite definitely sets himself up against all previous epic writers as one who is determined to outgo them. His stated reliance is on his Christian theme that contains revealed truth unknown to the ancients and is therefore automatically superior to any subject they could have chosen for treatment. At the same time, Milton strove to outgo his classical models not alone in theme but also in the art of literary composition. That is, he deliberately invited comparison with Homer and Virgit in his utilization of their structural and rhetorical devices, but always with a difference. The initial invocation is greatly extended and splendidly deepened, and, uniquely, other and even more personal pleas for enlightenment and support are voiced at crucial intervals. The epic similes are enlarged in scope as forms of prolepsis, irony, and characterization, and they are carefully shaped to achieve a previously unenvisaged coherence of elements in the two parts of the extended comparisons. Obviously, the formulas of epics needed to be enlarged to do justice to Milton's great subject. Yet as a literary artist he deliberately invited the reader's attention to the vitality and meaningfulness with which he had infused these traditional formulas that in lesser hands would have been palely imitative.

In the last paragraph of his preface to Samson Agonistes, also, he implicitly invites a comparison of his achievement with the dramas of Aeschylus, Sophocles, and Euripides by challenging only those readers to judge him who are acquainted with these "three 'Tragic Poets unequall'd yet by any, and the best rule to all who endeavour to write Tragedy." Milton would not have been Milton if he had failed to believe that in the view of judicious readers he would come off from the comparison not without honor. In matching himself against the Greek tragic writers Milton would again have trusted to his theme, which by the support of religious truth could not in his mind fail to surpass the dramatic subjects of the pagan world, its heroic history and its gods. But as he bad done in Paradise Lost, one would expect Milton in Samson to adapt the various conventions of Greek tragedy to the superior grandeur of his theme and to inform them with new life, not alone from the influence of his biblical subject but also by means of his own artistic invention finding new and more meaningful variations on the formulas of tragic drama.

Milton's preface to Samsan Agonistes is morc respectful to the tragedy of 
the Greeks than the comparisons of his own work with classical epic in Paradise Lost. It is not inappropriate to speculate that his admiration for ancient drama was higher than for ancient epic: we must not forget that when contemplating a work that would in effect justify his life of preparation, his first thoughts had turned to tragedy. At any rate, I take it that we do not observe in Samson so many of the technical innovations in traditional form that had marked Paradise Lost. Instead, we find within a framework of almost exact parallelism in external structure a conscious deepening of the significance, a new light on the means by which Greek conventions could be adapted to shadow forth the high significance of his theme, the relations of God to man in the working out of divine purpose. I suggest that in the end the new charge of energy that in Samson Agonistes runs through the old formulaic conventions transforms this dramatic structure by a sea-change in no less innovative a manner than the more technical alterations of epic formula with which he bad experimented in Paradise Lost. Indeed, I am bold to assert that in its Christian vitalizing of ancient tragic form Samson Agonistes produced a greater and more original triumph than the Christian epic of Paradise Lost.

Two related problems face any critic of Samson Agonistes. The first is the precise nature of the misunderstanding that Samson and the other characters have of God's purpose for him, a purpose not finally manifested until the catastrophe. The second is the exact mears, as dramatically represented, by which the misunderstanding is eliminated and a reconciliation is brought about.

One minority group of critics, perhaps basing their thesis on Dr. Johnson's famous pronouncement that Samson Agonistes is a play without a middle, sees Samson as another Promethets, the victim of extreme punishment, whose virtue is stoic or heroic suffering, simple endurance on the model of Job, until he recognizes the possibility for action offered by the feast of Dagon, seizes it, and achieves a mighty revenge for the indignities the Philistines had heaped upon him. Obviously, if this summary were true, the play would merely mark time by celebrating the virtues of stoic endurance up to the moment that Milton was ready to introduce what would have been the unmotivated catastrophe. That the ways of God to men would have been any further elarified by this dramatic program than in the relatively primitive and non-redemptive old Testament ethos of the story of Job is doubtful, and that Milton would have engaged himself to such a theme that controverts the message of Paradise Lost and then had the effrontery to claim for it the reader's "new acquist of true experience from this great event" is scarcely to be credited.

Fortunately it is more often held that Samson earns his way back to a reconciliation with God and that the action dramatizes this reconciliation as 
the central theme of the play. This view makes of Samson Agonites a redemptive tragedy not on the Greek but on the Shakespearean model, in which the hero after his tragic error wins through to a death in victory that justifies such a trust as Horatio's that flights of angels will sing Hamlet to his rest. Redemptive tragedy has its own special dramatic structure. However, at the moment the question is the nature of the misunderstanding that is turned to understanding in the reconciliation. That in the catastrophe God rescinds his estrangement and Samson once again becomes the champion of God and of Israel is certainly Milton's intention, one finally understood by Manoa and the Chorus and through them communicated to the audience in the magnificent close of the tragedy. What does not seem to be so clear to critics are the special terms of the reconciliation and the reason why these special terms impose the penalty of death on Samson.

The intention of Samson Agonistes does not differ from that of Paradise Lost in centering on the justification of the ways of God to men, a familiar quotation that can be read in two complementary ways: to make clear the justice of God's ways in dealing with man and to make clear to man the fact that God's ways are just. The lesson of Paradise Lost is that God's will cannot be controverted by Satan or by Adam. Since God's will is to good, what seems to be thwarting of that will by the success of evil is not a true thwarting. At best it is permitted and it is temporary, since the effect of evil is always to promote the good that obliterates the specific cvil of the Fall and its effects on mankind up to the ultimate healing of the breach of faith in the Last Judgment when good will reign forever and evil be permanently imprisoned. Samson Agonistes has a more concentrated aim: to dramatize a concrete and derived example of Adarn's disobedience and fall and the estrangement that follows. But the apparent thwarting by human means of God's Providence is there concluded in the triumphant demonstration that God always turns evil to good in a reconciliation with repentant man and in the resulting action that fulfills God's original purpose. As the first disobedience of Adam is a paradigm for Samson, so Samson may serve as a paradigm for any individual in the audience who must necessarily face the same problems of $\sin$, punishment, and reconciliation.

In this paradigm there is a crucial element that mystifies man. This is the apparent severity of the punishment that is linked with estrangement when man fails in his mission of fulfilling God's purposes. Actually, it is not the severity of the punishment itself for failure so much as the harsh estrangement that puzzles man's understanding of the paradoxical ways of a loving God. Specifically, the estrangement appears to confirm God's abandonment of His 
purpose along with the rejection of His agent. If this is so, then of course no punishment could be too severe for a man who had failed in his high mission through willful and avoidable human weakness and thus prevented the success of God's plan for good. But if God abandons this fallen agent and seeks for another through whom he may work to the same end, punishment represents only retributive justice-retaliation for no other end than destruction. Man may admit the justice of this retaliation for having failed the Almighty, but uncomfortable problems are raised which. Milton does not hesitate to face in Samson. If the Almighty selected an agent who in His forcknowledge $\mathrm{He}$ recognizes would fail so that the project had to be abandoned or a substitute put into the breach, the efficiency of such a system for getting the world's work done may well come in question, as well as the nutter of equity in the exccssive nature of the punishment that always sccms to follow on the failure that, after all, had been foreseen even though not predestinated.

The only reason that Samson represents a special case is that he had been chosen for a specific mission, unlike the general run of mankind whose destiny is to serve by standing and waiting. Milton's great theme was that good always overcomes evil, that no special agent can ever thwart God's purpose in employing him, even though he may initially seem to fail and to be discarded. God's ultimate plan is immutable, although the means by which it is carried out are conditional. The days of miracles being past, according to Protestant thinking, only rarely does God intervene dircetly in buman affairs but instead indirectly by the appointment of agents, who may be called His ministers. It is through them that He works to carry out His spccific intentions within His Providential view for mankind. The mission may be to see that justice is done in buman affairs, as in Hamlet's duty to bring justice to the murderer of his father, a concealed crime that the law was helpless either to detect or to punish. Or, as with Samson, some great step forward in the freeing of God's clyosen people from servitude may be proposed, a mission that Milton also believed had been given to Cromwell. Through such agents the slow process of justice is built up in the world that will eventually culninate in a redemption and restoration in the person of Christ on the Day of Judgment.

In this process two great ends are served. First, the world is prepared by experience for its final apotheosis. Second, as a part of that experience the lesson is given that although man must strive for his perfection within the framework of God's Providence, he cannot fully succeed by his own efforts but only through Christ. The blindness of the Israelites in Samson Agonistes lies in some part in their expectation that Samson, although manifestly a divine agent, but also an inheritor of original sin, could achieve a physical loosening 
of their boncls without working in them a corresponding spiritual frecing which the Messiah alone was destined to provide. The nature of spiritual freedom may thus be exemplified as much in human failure as in human success; and over the long course of history man may be taught that although he must continually strive, the only possible fulfillment lies in Christ. In this manner the world may be prepared for its ultimate redemption by the cumulative understanding of the real nature of perfection. Within this context retributive or conclign justice-meaning punishment with no other end in view but retaliation-was taken to be the fate of mankind in Old Testament days to break its stubborn spirit and prepare it for the acceptance of the salvation that was to be offered after the coming of the Messiah. In New Testament days the principle of salvation operates, since by exemplary, or redemptive, justice applied to error, each man may be taught to follow in the footsteps of Christ, which for Milton meant perfect obedience to the will of God. The purpose of punishment under the system of equity-mercy added to justice-that governs redemptive justice is to lead man to an understanding of the will of God when his own will has crossed divine purpose and alienated him from the supporting signs of grace. That man, so taught, can return to God's favor is the healing message of Samson Agonistes and its justification of the ways of God to man.

We may believe, then, that Samson Agonistes is a redemptive tragedy, that in pulling down the temple Samson once more became God's champion and -although in death-won victory, indeed a victory that on the analogy of the Fortunate Fall may be taken to be greater than he would have achieved if he had not fallen. God's will thus has not been turned aside by the human weakness of His chosen minister. The justice of Samson's blinding and enslavement has proved redemptive, not retributive as originally believed by all characters in the play.

It is true that the general blindness of Samson and the others rests on the misapprehension that his fault has caused God to abandon him, and that the purpose for which he had been selected as minister is now aborted. So long as this doctrine of despair holds, reconciliation is impossible, for Samson will not have the understanding to perform lis share of the reconciliation. The root of the misunderstanding spreads from the wrong interpretation of the evidence. No one in the play conceives of an alternative to Samson's return to his championship except on the original terms. Since an enslaved and blinded man, even though his strength is returning, is impossible to fit into the mold of the Sarnson who slew the Philistines with no other weapon than the jawbone of an ass, the present facts deny his championship; and any return in the future to his original role is envisaged only in terms of the restoration of his eyesight. 
In Milton's view, of course, what needs restoration is not the outer but the inner light that will support him in a new role. The whole basis for the theme of the blindness to the ways of God that permeates the tragedy is the belief that reconciliation must come only from God, and not mainly from Samson, and that it must result in a return to the original conditions of Samson's mission. In these terms the only subject for debate is by necessity the question whether Samson's sin was so heinous that God cannot be expected to relax His punishment, or whether--like Apollo in Oedipus at Colonus-He will arbitrarily at some future time accept Samson's suffering as payment and, not without some degree of self-interest, restore him as he was before his fall.

'This blindness illustrates the total lack of the Israelites' comprehension of God's ways in the balance between justice and mercy but particularly in the operations of His Providence in human affairs. Mercy is wrongly taken to be a total forgiveness that will restore Samson to the exact position he held before his sin. Paradise Lost demonstrates the opposite. Once sin enters and a minister falls by placing his own will in disobedience above that of God's, a conditional divine decree begins its operation that modifies the mission according to the changed conditions resulting from the fall. In Paradise Lost man is predestined to salvation, and mercy finds the means to achieve this great end in Christ's mediatory sacrifice. But Adam cannot work out his new destiny within the confines of the Garden of Eden as if the original sin that has now entered him were not. Spiritual death-which would be the utter condemnation of retributive justice-will be removed by Christ so that through the gateway of temporal death mankind will in the end be restored to a state of good that surpasses the state he would have achieved if he had never fallen. But the rules have changed. Although conditionally predestined for eternal life, just as if he had never sinned, man must first suffer the death that sin has brought. An Adam who will die has no place in the eternal perfection of the Garden of Eden. The original plan for his future, conditional upon his continued obedience, is now no longer operative and will never operate again on the same terms. Mercy that would wipe the slate clean and remove all consequences of sin without the satisfaction of the law is a sentimental and unrealistic proposition that controverts justice, in Milton's opinion. The road to Adam's restoration must now be trudged under very different conditions, even though the end will be his acceptance into glory, as before. That sin, although it will be forgiven, must first be punished according to the law, and that no agent of God who sins in disobedience will ever be restored to the exact terms of his original mission is the heart of Milton's understanding, as it was of Shakespeare's.

If God has proposed a mission for an agent, however, and this agent fails 
in his mission through sin, God's purpose has not been turned aside: the mission will still be accomplished but in a completely different manner from that by an unfallen agent, the difference representing the conditions of siniessness and the consequences of sin, of seeing evil through the eyes of good or good through the eyes of evil. The extension of mercy ameliorates justice but does not substitute for it. Mercy will modify thc condemnation that justice demands, but justice must be satisfied even though forgiveness is extended. In redemptive tragedy whether of Paradise Lost or of Hamlet, the price that the agent must pay is his death, but it will be a death in victory because the mission will still be accomplished even though in a completely unexpected manner from that otiginally understood. In tragedy the different manner requires the expiatory death of the fallen but now regenerate hero and his willing acceptance of that death as the essential means of victory. This is the law that corrective justice teaches him so that he is prepared for reconciliation when he is caught up in or engages himself to the catastrophic event. Hamlet goes to his death after submitting his will to God in the knowledge that a man's life is not in his own hands but in God's and that for man the readiness is all. We must believe that a similar enlightenment comes to Samson when be finds some rousing motions in him that lead him to accept the Philistine summons.

The blunduess in Samson Agonistes, then, is a double blindness. The first part has always been recognized-the despair that God has cast off Samson because of his sin of will. The second part has been less appreciated: the complete lack of understanding in the characters of the conditional alteration in the working-out of God's plan consequent upon Samson's fall, and thus of the changed terms on which God will still use him as His champion-the important difference being that Samson must pay the law by dying in order to win the victory, a champion once more.

If this is the theme of the play, as I suggest, then the means by which Samson comes to an understanding of his altered role and accepts the penalty in order to renew his mission must be the concern of the action. Within this action the significance of the three visitations (four if we count the Chorus) has been variously debated. A relatively cruile view of the tragedy takes it that the visitations of Manoa, Dalila, and Harapha, which comprise the main action of the play framed between the entrance of the Chorus and the appearance of the Philistine Messenger, are not placed in a cumulative, or developing, sequence. This is the gist of Dr. Johnson's notorious complaint that the play lacks an Aristotelian middle "since nothing passes between the first Act and the last, that either hastens or delays the Death of Samson," a view that he repeats in other terms as "the intermediate parts have neither cause nor con- 
sequence, neither hasten nor retard the catastrople." If this notion were to stand, the order of the interviews is random and they could be shuffled and transposed with no difference in their effect on the gathering of the forces that propel the ending.

The defence of Samson Agonistes attempts to find a rationalc in the visitations that makes of them true dramatic incidents arranged in a significant order and leading to a motivated and therefore meaningful catastrophe. Unfortunately, this defence against Johnson's stricturs does not spcak with one voicc. One school has found in the episodes the classic temptations of the World, the Flesh, and the Devil. There is much that is attractive in this way of looking at the visitors. Manoa can certainly represent the vanities of this world in the life of rest after toil that he paints for Samson as the only desirable or even possible sequel to his permanent defeat. The tempuress Dali]a adds to this life of sloth and gluttony the temptations of a sensual marriage bed as a form of nepenthe. Harapha tempts Samson by the sin of pride, which was the conventional gloss given to the Devil. The analogies are interesting and I think of some significance; morcover, they would represent an ascending order of trial. But in the end the explanation, although truc at onc level, is not wholly satisfying. Certainly it does not represent the ultimate answer since it fails to establish the relation of Samson's rejection of these temptations to his reconconciliation with God and the renewal of his mission.

Another school argues, to quote William Riley Parker, that "Samson's will is responsible for the catastrophe. ... 'Everything, therefore, which helps to determine Samson's will and to define his purpose leads to the catastrophe' [Jebb] ... As long as he doubts, as long as he questions, as long as he is anywise out of harmony with God's will, he is not a fitting instrument of God's purpose." This thesis is completely correct, so far as it goes, but it also is far too vague about the exact terms of the reconciliation as well as of the alienation. Moreover, in its charting of the preparation of Samson's mind for the decision that brings about the catastrophe, critics split as to the decisive incident. Some hold that the Dalila episode is the crucial one and that the whole point of Harapha's visit is not to provide a fresh temptation, with a corresponding enlightenment of Samson's will afler he has successfully surmounted its trial. Instead, it is held, Samson is completely prepared after the successful conclusion of the Dalila episode except that he is necessarily passive in the absence of any indication of a line of action open to him. Harapha, then, provides the required spur to action. Others see the Harapha episode as the crucial one in the series of three and hold that Samson's reactions proceed not merely from an external spur to action suggested in the course of the incident but instead from the 
inner enlightenment provided by his challenge to Harapha to combat in a trial of truth.

Such a serious difference of opinion about the structure needs to be resolved, of course. But even this need is subsidiary to the central question that does not seem to have found a satisfactory alsswer: precisely what is it that Samson and the other characters misunderstand about God's purposes, and how in the three visitations is Samson led to the truth that governs his catastrophic action. This can only be the truth that, transferred to Manoa and the Chorus from the action, brings forth the catharsis in then-and in the audience-of calm of mind, all passion spent; that is, the peace and support of understanding when the audience return to life after the fictive experience of the tragedy.

The first part of this question I have already endeavored to answer. The truth is that God punishes only irredeemable evil by retributive justice. Redeenable good, as in His ministers (scourges are quite another matter), is punished by corrective justice, the intent of which is to teach the way to an acceptance of reconciliation on the altered terms created by the new situation. That new terms are possible and that they will be extended to Samson is what no one in the play compreliends up to the point that the 'rouzing motions' begin to fill his mind and-alliough he never says so-he sees for the first time and accepts the new truth. His enlightenment, then, is not merely the general recognition that God las not abandoned him, which is true, but the more specific recognition that if he is prepared to make the required expiation by a willing acceptance of the final and necessary corrective punishment of death, he can satisfy in a new manner the original requircment of his mission, although at the price of "Inevitable cause At once both to destroy and be destroy"d." The "rouzing motions . . . which dispose / To something extraordinary [his] thoughts" both are and are not his own, for any religious-minded member of the audience would recognize them as an impulse sent from God, the frst time that God has communicated with Samson since his betrayal of faith. It follows that at this point Samson has in a sense earned the re-establishment of commurication by the traditional way of having brought his will once more into harmony with God's.

This harmonizing of wills, required before the catastrophe can hold any significance other than the terrible jevenge on the Pliilistines for which Manoa at first mistakes it, has been recognized by critics like Parker. The difficulty is that although these critics have perceptively traced the rise and fall of Samson's moods in each interview and have shown him rejecting false interpretations both of his past and present conduct, little has been advanced that reveals how he may be successively coming closer to the specific truth that the rousing 
motions forecast. If each interview in some essential matter clarifies his mind so that he could not have met the test of the second without having surmounted the first, or encountered the third without conquering the second, then the play has a middle and the episutes are connected by a chain of cause and effect that may properly be said to motivate the catastrophe. If instead there is no successive and rising tide of clarification that prepares lim to receive the "rouzing motions," then the criticistn is true that places the greatest emphasis on the Harapha incident and alleges that the interviews with Manoa and Dalila do little or nothing to advance the action.

The prime difficulty I suggest comes in the disparity between Samson's correct actions and the lack of conscious understanding that he reveals about these actions. If it is a question of observing the development of his own enlightenment as manifested in his words, one can easily see how Dr. Johnson and the orher critics like Chambers and Verity were misled. The basic response Samson has to Manoa is that he cannot serve his nation or his mission by sitting idle on the household hearth, a burdensome drone

\section{till length of years}

And sedentary numness craze my limbs

To a contemptilule old age obscure. (570-572)

On the other hand, he has no answer to Manog's counter-argument that he can scarcely serve his nation while in chains as a slave, and he confesses himself deserted by Heaven:

Hopeless are all my evils, all remediless;

This one prayer yet remains, might I be heard,

No long petition, speedy death,

The close of all my miseries, and the balm. (648-651)

The action here is right, for if he had obeyed Manoa he would once more have interposed his will against God's by secking to cut short the punishment that justice had visited ypon him. Yet his resolve to remain drudge at the mill is instinctive, not reasoned, for the only end he foresees from his remaining is an earlier death than if he were to linger out his days in ease at home with Manoa. The decision is a right one, but his reasons are unfocused and despairing. Perhaps even more sharply, his sole interpretation of Dalila's visitation is that

God sent her to debase me,

And aggravate my folly who committed

To such a viper lis most sacred trust

Of secresie, my safery, and my life. (999-1002) 
This is still taking himself as the recipient of retributive justice, the coming of Dalila prompted by God only to punish him further. His rejection of Dalila was well founded, for if he had accepted her form of comfort he could never have been received back into God's favor. But the action is not consciously taken and the grounds appear to differ little from his rejection of Manoa's appeal. If there is any advance in enlightenment between his reactions to the two visitations, the distance is imperceptible. That he has learned anything about himself that will aid him in correctly interpreting his relations with God can scarcely be demonstrated from his words. Neither abasement nor stoic suffering is enough, no matter how heroic, if it does not lead to enlightenment.

On the other hand, if we look not to Samson's own words but to the understanding by the audience of the inner significance of his deeds, even though performed in blindness, the case is altered. What Samson sees as retributive justice, offering no escape from punishment except death, the Christian audience interprets rightly as corrective justice, the intent to instruct not Samson alone but all Israel (and of course the audience) as to the conditions of redemption so that at the proper time God may once more send an impulse to his servant Samson. At the start of the play and the dialogue with the Chorus, Samson is aware of the heinousness of his crime. He accepts full responsibility and does not endeavor to shift the blame from himself, where it belongs. It was his weakness that led him to break his faith under a stress that could have been withstood. To this extent it is commonly recognized that the ground is prepared for eventual reconciliation; what holds it back is his despair. Critics make much of the progressive bringing of Samson's alienated will into harmony with God's, but they do not entirely face the question of how his will is out of harmony and how in the Manoa and Dalila episoles it moves toward harmony. That there is no harmony at the start between God's purpose to renew his championship and Samson's despair at being deserted is clear enough. It is a legitimate question, however, to what degree, if any, his will has altered between say, the entrance of the Chorus and the departure of Dalila so that a progression may be observed. Up to the coming of Harapha, the answer must be that there is none if we take only the evidence of Samson's own understanding. It is to his actions that we must look for what is in fact happening. In one sense his responses to Manoa and to Dalila are negative in that he refuses to be swayed in any direction that will ameliorate his condition. He does not recognize what his refusals were aimed at: all he knows is that each suggested course of action would be a flight from his punishment. That his punishment has any other end than retaliation is not understood. What he does know, however, is that if God purposes to punish him, he would be setting his will 
against God's by attempting an escape. Thus his actions, though negative and without hope of redemption, are actually positive in their result, and from the point of view of the audicnec-though not of Samson-his state at the end of the Manoa episode differs from that at the beginning. I suggest that what the audience sees happening is a dramatization of the three stages of repentance as worked out in Book 1 of Sperser's Faerie Queene in accord with the conventional teachings of the clurch. We should remember that to Milton Spenser was a better teacher than Aquinas."

Like Samson, the Red Cross Knight after his breach of faith with Ducssa and his encounter with Despair is in no condition to attempt the conquest of the dragon until he has been inwardly liealed and thus qualified for the dispensation of mercy. Fidelia brings hin to the first stage of this process of 'trew repentance' by instructing him in the nature of sin so that

That wretched world be gan for to abhore,

And mortal life gan loath, as thing forlore,

Greev'd with remenbrance of his wicked wayes,

And prickt with anguish of his sinnes so sore,

That he desirde to and his wretched dayes:

So much the dart of sinfull guilt the soule dismayes. (1.10.21)

The difference betweet this dismay and the form allegorized in the earlier dispute with personified Despair is important. Red Cross had encountered Despair in full conficlence but was abruptiy brought low by arguments based entirely on the principle of retributive justice that offered no hope of forgiveness for the irremediable heinousness of his sin. Against this argument he had no defence, for he lacked the protection of formal repentance agatinst the hopelessness of his position now so pervertedly thrust home. It is true that, on the surface, under Fidelia's guidance Red Cross also feels a horror and an anguish that make him wish to end his life. But it is crucial that it is Faith who instills this recognition of the real nature of his crime and so the purpose is not retributive but, instead, the necessary prediminary to the redemptive process. By church teaching, a sinner can prepare himself for mercy only by first understanding the nature of his sin. This preliminary, I suggest, is represented in Samson's opening soliloquy in which he is assailed by his restless thoughts like a swarm of hornets. We must take it that despite his acceptance of full blame for his fall, Samson is not "repentant" in any fulfilled sense as Spenser saw it; and Milton powcrfully illustrates his bewildered state of mind by the fevered questionings which foster only despair.

Spenser makes it clear that this same state of mind in the Red Cross Knight 
is only the preparation for repentance and by no means the start of the actual process. Red Cross sees no hope despite the comforting of Speranza, and Una is forced to beg Coelia for ald. Coelia fetches Patience, a doctor who has insight into the disease of grieved conscience, and only then does the cure begin. The words of wondrous might that Paticnce speaks to Red Cross do no more than reduce the emotional pain and confusion of his grief so that he may endure its burden. So far as his sin goes, Red Cross is still in a position wherein

the cause and root of all his ill,

Inward corruption, and infected sin,

Not purg'd nor heald. $(1.10,25)$

His diseased conscience is finally cured by the scourges of Penance and Remorse and by healing Repentance. When once more whole he is brought to Una, Spenser attributes the alteration to the ministrations of "wise Patience And trew Repentance." We must take it then that in his encounter with Despair Red Cross lacked this patience, and thus that the process of repentance could begin only when he was prepared to bear his burden with fortitude, not in a state of high and confused cmotion as to the issues involved. Penance scourges his mind and Rcmorse his heart until his corruption is purged, while Repentance washes away his sins with therapeutic salt water. The distinction between penance (which contains remorse) and repentance is theologically a shatp one. Penance exhibits sorrow and contrition for sins, whereas repentance is won only subsequently by a thorough hatred of them and a change of mind, a firm resolve not to repeat the sins that have brought one low.

The first stage of purgation, the demonstration of patience, may be assigned to Samson's dialogue with the Chorus. Instead of the restless questions of the soliloquy, Samson now is comforted by the support of friends. His anguish remains but he is able to assert that the blindness he had bemoaned in his soliloquy as the worst now afflicts him least in comparison with shame at his betrayal of God. The discussion of ingratitude leads to Samson's conclusion that although he has been deserted by men and by God, men may not neglect God's proposed deliverance as they have now reglected him. In distinguishing between the blame to be attached to him and to his nation which failed as well, Samson has learned to accept with patience his guilt, but he properly refuses to accept more than his share. This is in fact an important clarification of his degree of responsibility and of guilt, and he thereupon is in a position to bear his own share with as much fortitude as can be mustered in his anguish.

The emphasis upon sorrow and contrition becomes more marked in the Manoa episode: 
Appoint not heavenly disposition, Facher,

Nothing of all these evils hath befall'n me

But justly; I my self have brought them on,

Sole Author I, sole cause. (373-376)

Samson recognizes that the present

base degree to which I now am fall'n,

These rags, this grinding, is not yet so base

As was my former servitude, ignoble,

Unmanly, ignominious, infamous,

True stavery, and that blindness worse then this,

That saw not how degenratiy I serv'd. (414-419)

His action in refusing Manoa's offer of a retirement to soft ease is instinctively correct in that it is not his right to decide when the punishment shall end. Since Samson still sees the punishment as purely retributive, he intends to bear it until his hoped-for death, which alone will offer peace. On the other hand, the patience that he derived from his interview with the Chorus enables him to understand more clearly than before the exact nature of his crime, which he correctly imputes to effeminacy (or lack of fortitude) following on pride. By insisting on the endurance of his humiliation so long as God wills it, he is showing in the only way he knows his sorrow and remorse, and he has definitely moved into the second stage, that of penance.

The final stage of repentance, I suggest, is dramatized in the Dalila visitation where two very important decisions are made. The first consists of Samson's refusal to repeat his former sin, the effeminate subjection of his will to Dalila's. No more telling proof could he given of his repentance, his hatred of the sin that caused his downfall, than this rejection of the opportunity to repeat the same temptation. This is the theological test of his finess for redemption. To my mind, however, the second decision-the forgiveness of Dalila-is equally important, no matter how ironic the terms in which he delivers it. If Samson cannot forgive an enemy-the audience knows from the biblical injunction-God cannot forgive him. Samson has no hint of the true significance of this action, nor does he even recognize it as significant, perhaps, lut it is crucial. Without it his salvation is impossible, for his hatred of his own sin must not be confused with an unforgiving hatred of the imperfect woman who tenpted him to his fall. It is by no means entirely implausible that Milton had some understanding of the modern psychological doctrine that forgiving the one who brought disaster is forgiving oneself. As I understand it, this self-forgiveness means that a person is prepared to accept himself for 
what he is and has cleared his mind of the poison of self-punishment in excess of fact or responsibility, a deadly neurosis. In this self-understanding frame of mind one can deal with the consequences of an act without attempting to free oneself by blaming others or else by imprisoning oneself in a mental labyrinth from which no escape is possible except into a breakdown and from which no action except for suicide can evolve. As Adam and Eve must forgive each other before they can seek a reconciliation with God, so in forgiving Dalila Samson has fnally healed the running sore of despair; by this change of mind he has prepared himself, though unwittingly, for the further change that is to take place in the Harapha episode.

That Samson is without self-consciousness of this rise from fortitude to penance and then to repentance is no evidence that Milton was not working within this general theological sclieme. In the first place, Milton is a dramatist and as a dramatist he is properly more concerned with action than with exposition. It is the duty of the audience to interpret the action and to recognize the ironic gaps between speech and apparent motive and the true test of action. In a play so loaded with irony it is a structural irony that correction and redemption come to Samson almost completely urawares, in the sernse that he has no inkling of the formal process through which he is progressing, and thus his actions are instinctive rather than coherently planned to win his reconciliation. Secondly, the church's teaching of the formal process of sin, punishment, and redemption is a strictly Christian concept, and in the Old Testament story of Samson it would be highly arachronistic to portray Samson as consciously following a Christian path. On the other hand, Milton's Christian audience was accustomed to interpreting Old Testament stories as types of New Testament things to come. Hence there is nothing anachronistic in Milton's presentation of underlying Christian concepts natural and familiar to the reading audience as the basic facts from which the interpreation of the action must derive although these principles are unknown to the dramatic characters involved. The formalities of the system may vary between Old and New Testament, but the continuum of men's relations with God is unbroken.

The test of the theological basis for this progression comes in the Harapha episode, about which there has been real confusion. Those critics who believe the Dalila incident to be the crucial one hold that Samson's mind is then settled and he thereupon needs no more than the opportunity and the spur to action to demonstrate the plateau of understanding, or enlightenment, that he had there reached. If this is so, the climax of the play has passed, and Samson's reactions to Harapha will follow as the anticlimax, the natural and indeed inevitable effect of the cause-the turning point in his understanding reached in the 
interview with Dalila. Another school holds that the Harapha episode is itself the true turning point, and that a tomptation and trial cxist in this scene comparable to and perhaps greater in severity than those represented by Manoa and Dalila, and that it is in the passing of this final test that the highest level of enlightenment is reached.

The truth lies somewhere between these two extremes. If one argues structurally, it is dificult to think of a temptation more important than the renewed circumstances of the original tragic error which Samson, now in full understanding of the nature of that error, refuses to repeat. It was his pride, he statcs, that led to his effeminate subjection to Dalila and the betrayal of his secret. If Harapha represents a trial by pride, then the reversal of the order produces seriously diminished returns. Samson's effeminacy did not lead to pride, but pride to effeminacy. On the other hand, if in some manner Harapha offers a rising scale of trial, there is little unanimity, or even any credible specific suggestions, as to the nature of the temptation that makes it more important than the trial offered by Dalila, a repctition of the original error. True, the three-part encounter witly the World, the Flesl, and the Devil has a superficial attractiveness. Pride is certainly taken to be the greatest of the Seven Deadly Sins from which all the other six flow. But Pride can be elevated to the climactic intervicw only at the expense of downgrading the theological significance of the hatred of sin accompanted by a resolve never to repeat it which forms the basis of repentance. If in fact Samson has unwittingly repented in rejecting Dalila, though with forgivencss. Pride has no true theological place in an ascending order of temptation. In short, if the final temptation of Pride must be surmounted before Samson's mind is fully illuminated, then the system of Patience, Penance, and Repentance is either non-existent or is stabsidiary to another and more important progression, the nature of which is obscure. Moreover, how Samson surmounts the sin of Pride in the Harapha episode is by no means clear.

Fortunately it is possible to reconcile these two opposites on the basis that the Dalila episode is structurally the climax of the play. Nevertheless, the dramatization of the encounter with Harapha needs analysis for what it actually contains. We may divide it into two main parts to which the coda of Samson's reaction is attached. The first part consists of the usual preliminaries to battle, each character describing his own prowess in an attempt to gain a psychological advantage over his enemy. What is important for our purposes is that it is a purcly personal encounter of two figliting men representing their respective warring nations. Harapha scorns Samson's present degradation and boasts that he would have defeated Samson even in his prime. Samson defends 
his present state as brought about by Philistine guile, not prowess, and challenges $\mathrm{Harapha}$ to a single combat man to man. This part ends when Harapha declines the proposal and suggests that Sarnson's past invincibility was given him by magic. Samson's answer introduces the second part of the encounter. In the first, it will be noted, Samson offers combat as a private man, not as a representative of his nation or of his God. But Harapha's sneer produces a vital reaction. His strength, Samson returns, came not from magic but from God and had been divinely given to God's champion and minister. A challenge now follows on very different terms: Samson's indignation leads him to offer himself in a combat for a trial of truth. Judicial combat is a formal and wellrecognized means of determining truth in cases where evidence is too uncertain for the legal process to decide. Thus in extremity two antagonists place their truth in the hands of God, and the result of the official combat is taken to represent God's decision. The case is best known to most of us in the procedures for the aborted combat for trial of truth between Bolingbroke and Mowbray that opens Shakespeare's Richard II. The significance of this shift of ground from Samson as private to Samson as public champion is emphasized by the scries of three challenges which he delivers in this new role. In the first, he challenges Dagon in the person of Harapha to stand up to the test against Israel's God in hirn. On Harapha's response that his God has deserted him, Samson is led to the new position that confident of final pardon he can issue a second challenge to combat. This second defiance leads to a dispute about Samson as a murderer and a member of an enslaved nation, to which he responds disclaiming responsibility for the venality of his countrymen and asserting that he has never been a private person but an agent assigned by Heaven. On this basis the third challenge follows, which Harapha turns aside before he retreats, leaving Samson exhausted and discouraged at the apparent failure of his action.

Critics have been prompt to point out the shift in the first and second of this series of challenges in which, stung by Harapha's taunts, Samson in answering them is led to a partial assertion of his continued championship in the first and a tacitly full assertion in the second:

\section{yet despair not of his final pardon}

Whose ear is ever open; and his eye

Gracious to re-admit the suppliant;

In confidence whereof I once again

Defie thee to the trial of mortal fight, 
By combat to decide whose god is God,

Thine or whom I with Isracls Sons adore. (1171-77)

Because this is the first statement of any confidence of pardon, and because it links with no earlier statement in the first two visitations, the theory has been proposed that Harapha acted as the spur, and that nothing in the nature of a trial is present in the episode. In defending the purity of his God, Samson is automatically led into a defence of the purity of his own divinely jrompted actions up to his betrayal, and thence, in the heat of the challenges, to a confidence that in this confrontation he will still-though blinded-be able to act as champion. This is a fair statement of the position and if, as commonly, Samson's returning confidence in himself as agon is taken as an enlightenment, it is impossible to find in the latter part of the episode the overcoming of any temptation to pride. On the other hand, an argument might be raised that in his challenge as a private person Samson differs from the position he adopts in the series of three that follows. If this were Milton's intention, however, the language effectively conceals it. Certainly it is proper to ask what response other than his first disgusted challenge to a boaster one would expect from him, and what pride is shown in it. Milton distinguishes the private from the public defiances, but as a dramatic device to show how Samson under presstee passes from a simple to a complex reaction in his understanding that this trial has implications beyond a simple man-to-man fight.

There are only two options. If God has sent Harapha as a punishment for a further and ultimate humiliation, then he is indeed lost and only retributive justice can be heaped on him until his death. This was his former attitude about Dalila's visitation. I suggest that, again instinctively for himself but with the full knowledge of the audience as to the issues, the crucial test of Dalita has in fact strengthened him to admit the other option, the possibility that the punishment has been corrective and that God will pardon him in the end if he will act correctly in accord with God's will. The distinction between the two sets of challenges, then, marks the transition to an understanding that Harapha, like Dalila, was sent for other reasons than aggravation of his fault. He closed the Dalila episode with forgiveness. If Harapha has any element of test, Samson meets the test by passing from a private to a public challenge. If one were to work hard at it one might find some suspicion of an escape from pride in the new terms, but if so it would appear to represent only a latent danger, not a visible one. In a sense Samson does pass from failure to triumph in thus shifting his ground, but that docs not signify that the audjence would need to disapprove of his first challenge as an error. Admittedly it is incomplete and 
not ethically based. Nevertheless I take Milton's arrangement to represent more a dramatic motivation than a testing ground on which Samson's fate wavers in the balance between sin and virtue. The transition marks the difference between alienation and partial reconciliation, of course. In the first two interviews, supplementing the dramatic treatment of the opening choral dialogue, without Samson being conscions of it God has moved closer to him." In the second series of challenges Sarnson makes his first conscious step toward God.

The question now follows: was Samson's enlightenment complete when he hoped for pardon and in that confidence challenged Harapha as two representatives of their gods? The answer must be, no. Granting that Mitton was not prepared to rewrite the Bible story, let us speculate on the effect if under the new terms Harapha had accepted combat and Samson had killed him though suffering his own mortal wound in the process. Would the understanding of Manoa and the Chorus, and the final catharsis for the audience, be substantially the same? If the answer is yes, then Milton's invention of Harapha and his retreat would be only a desperate expedient to retain the biblical ending, an arbitrary foreclosing of an impossible situation like the rescue of the Lady in Comus before the brutalizing drink is forced between her lips. Such a reductio ad absurdum shows us that something is still wrong. Samson's discouragement when Harapha escapes him is like his exhaustion at the end of the Dalila episode and its comment no more to be trusted as to what the audience is to think than in the episode before. The case may be clarified perhaps by inquiring whether any audience would take it that Samson's hope for an ultimate pardon that will enable him to fight Harapha as God's champion is prompted by himself or by God. The whole weight of the evidence suggests that this affirmation is self-prompted, Samson's own move toward a waiting God. Any other view, in fact, would destroy the religious and dranatic impact of the "rouzing motions" that later change his mind about following the Messenger to the Philistine festival.

Samson has attested to the communication of God with him through impulses, as in the marriage with the Woman of Timna. There can be only one impulse in this tragedy: it must be that which leads Samson to obey his fate and complete the reconciliation by the expiation of a death in victory. According to this point of vicw Samson's own positive action toward reconciliation, the second set of challenges, is necessary and admirable as a recognition of the difference between retributive justice and the corrective justice that has actually been visited on him, but it falls far short of full enlightenment. In the nature of the case this final illumination or impulse should come from 
God and must thereforc be concentrated in the "rouzing motions" which he feels only at a later time. Critics have usually held that the true enlightenment was his assertion that he would fight Harapha as God's champion, confident in his hope of pardon. Redemptive as Samson's challenge is, it leads to no dramatic action, for Harapha skulks off with futile menaces and Samson is back where he started for an opportunity to act. This ending to the episode is itself the firmest evidence that what Satnson proposed was not acceptable to God.

The reason for Milton's treatment is clear. In challenging Haraplua to combat, whether as private or as public contestants, Samson was attempting to recreate the past in the exact terms of his former mission, and he hoped for success despite the seemingly insurmountable obstacle of his blindness. This thinking is in line with the blindness of Manoa and the Chorus throughout the play in believing that God will forgive Samson, if $\mathrm{He}$ does, by some miracle that will testore his sight so that everything would be as it was before Samson's betrayal. As I have remarked, this frame of mind shows no understanding of the way in which God works to repair evil. Adarn's expulsion from Eden was necessary as well as symbolic. The consequences of original sin will be removed by Christ's sacrifice, but the effects of the sin will remain in the form of temporal death until the Day of Judgment. Things can never be identical once evil has corrupted. Good will counterbalance the evil, and more than counterbalance it, but the death that Adam ate will not be lifted. Physical death, however, will ultimately turn into spiritual victory over Salan in the immortality of man within the body of Christ.

The theme of sctributive tragedy known to the Greeks celebrated the heroic endurance of the protagonist, because there was little else to celebrate in a pagan world. Even in Oedipus at Colonus, which comes closer than any other Greek tragedy to the ethos of Samson Agonister, much closer than Prometheus Bound, the tragic stoicism merely tries to seal off man's responses to ill and thus to glorify fortitude in adversity, for life would otherwise be intolerable. The greatness of human character is manifested by Promethean resistance to irreparable external situation. On the contrary, redemptive tragedy is almost exclusively a Christian phenomenon, with its own rules. It is a tragedy of error, too, but of error repaired by willed action that alone is positive and meaningful and that alone can reaffirm God's mercy and justice. The two great lessons that Samson Agonistes teaches are that God's justice is redemptive, not retributive, and that good will always overcome evil according to a large design which cannot be altered by the human failure under stress of an agent selected for a special mission in God's Providential system. For Manoa and the Chorus the stunning cathartic enlightenment that closes the tragedy is revealed 
as the unerring power of divine good working through fallible man. The only terms of reconcilation previously envisaged had been appropriate to the Old Testament and had been little different from the arbitrary lifting of retributive justicc after heroic suffering in the Oedipus at Colonus. All characters in the play conceive of Samson's futare in the single terms of the original mission. When this mission is aborted by his tragic error and his blinding and enslavement, no other repair of the damage is dreamt of except a relaxation of the punishment at some future time-and a miracle to restore Samson to his former state so that the mission can then continue as if it had never been interrupted.

In this context the Harapha episode-for action-is a dead end. In it Samson has spoken to God but God has not yet spoken to Samson. The spur to action provided by Harapha is both wrong and impossible as Samson responds to it: it is still his understanding that history is repeating itself. Although handicapped by blindness, he proposes to fight on the same terms as before his fall and to conquer his enemies by force of arms in open combat. This proposal marks an incomplete enlightenment as to God's purposes and it would have proved unacceptablc, one reason why it must not take place. Yet we are not to suppose that by this wrong interpretation of experience, Samson las failed God again; it merely signifies that corrective punishment has not provided the full Iesson. Milton presents the episode as the final reach of what the uncrightened human understanding, in an Old Testament context, could comprehend of divine purpose before the principle of sacrificial mercy, not arbitrary mercy, was announced in Clirist. Non-Christian human reason is not enough, for it misses the essential truth that one cannot go home again. No more than Adam can escape the penalty of death for sin can Samson escape his blindness and be restored to vigorous championship in combat, or even to a blind-man's victory over Harapha. His fall from grace did not alter God's purpose to crush the Philistines, but conditional upon his fall the means must necessarily change by which that purpose will in the end be unerringly fulfilled.

The changed means involve the grand principle of reconcilation through expiation. Within the framework of free will, men on earth fulfill divine purpose, particularly those special agents like Samson who have been set apart as ministers of Providence. Although Samson fails and believes that he has been cast off, God's purpose remains unwavering. However, human reason has difficulty in understanding this unfaltering divine purpose because men expect the purpose to fulfill itself in the identical terms of the original plan. But Sanson's fault changes these terms, though not the essence of the plan. The original victorious end will still be fulfilled but it will be altered to a quite 
different action that will require Samson's expiatory death as the willing payment for reconciliation. It is this final transfornation that Samson glimpses in its "rouzing motions," the return of the communication with God in the divine impulse that in the past had prompted his ministerial actions. The command of the Messenger is correctly intcrpreted as the opportunity to follow God's will, not Samson's own, and in the holocaust that follows the pulling down of the temple, Samson fulfills his original mission-despite his necessary death-more terribly than by any symbolic victory over Harapha. His challenges of Harapha had not been incited by God, but in the new action at the temple Samson is a God-guided man once more. The knowledge that this exchange of expiatory death as the price of victory is just, and redemptive, reconciles the audience to the tragic penalty that justice must always exact for sin even though forgiven. Indeed, the forgiveness lies in the terms of the penalty for reconciliation. The victory achieved in death, then, is the visible sign of the final reconciliation of the hero with his God, and of divine acceptance of the results of his mission. The function of mercy to ameliorate justice by the acceptance of sacrifice is the true experience that Manoa and the Chorus learn; and througb them the audience can understand the fulfilment of Old Testament history in the New, for the profound effect of the catharsis in the audience is of course powerfully Christian. The ending not only shows that God's ways are justifiable to man, that divine purpose will work itself out inevitably even though obscurely to human eyes, but that the requirement of sacrifice from men is not retributive but redemptive. What the audience knows as the last measures of the kommos fall on their ears is the exaltation of the Christian experience working itself out through the range of human history.

All is best, though we oft doubt,

What th'unsearchable dispose

Of highest wisdora brings about,

And ever best found in the close.

Oft he seems to hide his face,

But unexpectedly returns

And to his faithful Champion hath in place

Bore witness gloriously; whence Gaza mourns

And all that band them to resist

His uncontroulable intent,

His servants he with new acquist

Of true experience from this great event

With peace and consolation hath dismist,

And calm of mind all passion spent. 


\section{Notes}

1. In De Doctrina Milton enumerates the progressive steps of repentance as "conviction of sin, contrition, iud departure from evil, conversion to good" (sec Maurice Kelley, Thit

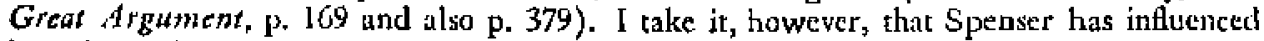
him draraatically in Samson Agonistes. All quotations from Samson Agonistes conform to the first edition, London, 1671 .

2. In a divinely ordered world, God had in a sanse sent Manoa and Dalila to him. Onc may profitably recall Milton's discussion in De Doctritna, chap. 8, of good temptations, Iohn Milion: Complete Poems and Major Prose, ed. Merritt Y. Hughes, p. 988.

3. Just so, Hamlet reacts to a messenger from Claudius and brtushes aside Horatio's alarm at the pain about his heart and the advice to forgo the fencing matcl. In the readiness-is-all speech he submits to God's designs the human will that had flared in opposition to God in the mistaken killing of Polonius. See my "Hamler as Minister and Stourge," PMLA, 70 (1955), 748-749, but more particularly "Death in Victory: Shakespeare's Tragic Reconciliations," Studies in Honor of DeWitt T. Statnes (1967), pp. 68-71. Page 71: "The tragic experience of Hamlet, therefore, exlibits error and then reconciliation through a return to God's plan. As later in Samson Agonistes, the indience is elarified as to the unclangeability of God's purposes by seeing them triumplant despite the momentaly falling-off of the protagonist. The knuwledge that the punishment of death visited on Hamlet and on Samson is just, but that a higher equity stemming from nercy will bring them to their rest, reconciles the audience to the tragic penalty that justice must cxact."

4. Long before the Renaissance Samson had been explained as a type of Christ, but Milton is not working with such a pattern. Instead, his concern with such typology for Samson is concentrated on the Old Law repetition of Adam's fall and his future redemption under the New Latw. 


\section{The Subscription List for Pope's Iliad, 1715}

\section{By MatThew Hongart}

Among the "Names of the Subscribers" printcd at the beginning of the first volume of Pope's ttanslation of Horner's Ilad, published 6 June 1715, the most familiar today are those of Joseph Addison and Sir Richard Steele. But what of the others? Many of them were persons of considerable distinction among their contemporaries. Leslie Stephen calls the list "almost a directory to the upper circle of the day." Pat Rogers, a leading authority in this field, says that this appraisal is "a slight exaggcration. There were more aristocratic subscribers to Joseph 'Trapp's Virgil in 1718." But whether Stephen or Rogers is right, the list is a valuable guide to the upper classes of Queen Anne's and George I's England, and on inspection proves to possess some striking religious, political, and social features.

The list is headed by "Her Royal Highness the Princess," who was, of course, Caroline of Anspach (1683-1737), Princess of Wales, and future Queen, a famous intellectual. No other member of the Royal family appears. There are 562 other individuals (plus 11 Oxford Colleges and one Dublin College, with one duplicated name, making a total of 575 entries). The breakdown of the 562 is as follows, roughly in the order in which the categories appear, under each letter of the alphabet, in the list. (These figures and others in this paper cannot be considered as completely accurate because of the dificulty of making certain identifications and of placing each name in the sight category; but I bope the errots are not significant.)

Dukes and Duchesses

Marquesses and Marchionesses .................................... 4

Earls and Countesses ..................................................... 59

Viscounts and Viscountesses .......................................... 13

Lords and Ladies (Barons and Baronesses

plus Lords Chief Justices) .................................... 45

Children of peers (with courtesy titles or "Hons.") ....... 34

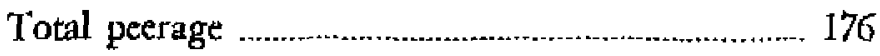

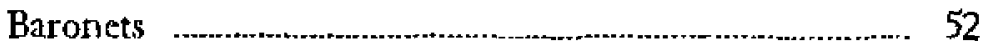

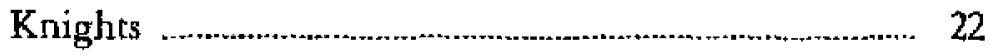



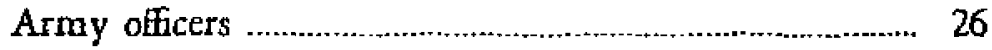

Clergy (including 2 Roman Catholic priests) ................. 25 
Doctors (medical, legal, musical)

Mr. and Mrs.

Without looking too closely at the meaning of some of these titles, one can say that nearly $30 \%$ of the subscribers belong to the peerage, and over $40 \%$ are titled.

The peerage and baronetage have many connotations, some antiquarian, some quasi-nagical, but the main significance of titles, in my view, is that they are indicators of wealth and of power. Most money in 1715 was in land, and the higher the titles the more land the owner and his family were likely to possess. The Dukes werc for the most part the greatest territorial magnates, the Earls on the average were richer than the Barons, and so on. Moreover, the higher the title the greater the share of political power and public money the owner could expect to obtain. The King's Servants in offices of profit, which included both ministers in something like the modern sense, and pure courtiers, were drawn largely from the House of Lords, and a King's Scrvant could expect not only large profits for himself, but pensions, offices, and sinecures for his relatives and followers. A great nobleman could also find it easier to get Bills through Parliament to assist the development of his country and town property. It was possible for a King's Servant to "nuingle" public and private money to his vast profit, as was practiced by Paymasters Brydges (later Duke of Chandos) and Walpole. There were very few exceptions to this correlation of rank and wealth: promotions to a higher rank did not take place unless the peer to be promoted could afford the increased expenses in keeping up the appearances by building and entertaining that the higher rank demanded. Sometimes a lawyer, soldier, sailor, or statesman would be given a peerage for outstanding services, but most in these categories, except possibly that of lawyer, came from the wealthy landed families in any case. There were ratler few "poor Lords," although there were some very wealthy baronets and plain squires. There are some exceptions to the correiation between titles and political power, since Dukes and Earls did not always possess the ability to handle affairs of state. For many years in Pope's lifetime the government of England was effectively in the hands of a plain squire, the head of the Walpole family of Norfolk; and the untitled greater landlords, who figure prominently, as we shall see, in the list, also played an important part in English political life.

There were three peerages in Great Britain, the English, Scottish, and Irish, each of a rather different nature. It is difficult to state the size of these peerages, because of technical matters concerning extinctions, abeyances, dormancies, attainders, etc. Sir John Habakkuk, the leading authority on the eight- 
eenth century nobility, writes that there were 161 temporal peers (English) in 1704; Queen Anne created only 30 new peers, but because of extinctions the number at the end of her reign had hardly risen, and indeed there were only 182 peers as late as 1780 . Another authority states that there were at the time of the Union, in 1707, 164 English peers (1/32,000 of the population), and 154 Scotish peers (1/8,000 of the population, four times as great a proportion). The size of the Irish peerage can be judged from the list of peers present in (Tory) and absent from (Whig) James II's Irish parliament of May 1789 (Complete Peerage, Vol. III, Appx. D), a total of about 111. 'T'he number of new Irish creations between 1689 and 1714 was probably balanced by the number of extinctions, so that the total would have remained about the same (although later in the century the number of Irish peerages rose very rapidly). The total for the three Pecrages was therefore about 430.

The majority of Pope's subscribers among the nobility belonged naturally to the English peerage, since this was by far the most important of the three in the political, literary, and aesthetic life of London. Of the serior peers, some held titles in two or even three of the peerages, but it is safe to say that of the Dukes, twenty were primarily English Dukes, and of these twenty, fifteen are represented in the list, an impressive proportion. The non-subscribers were Cleveland, St. Albans, Berwick (abroad, in the French Army), Schomberg (an elderly soldier), and Bedford (a boy of seven). Richunond is represented by his son and heir (hereafter $\mathrm{S} \& \mathrm{H}$ ) with the courtesy titfe of Earl of March; Bolton by his $\mathrm{S} \& \mathrm{H}$ 's wife, the Marchioness of Winchester; Leeds by his $\mathrm{S} \& \mathrm{H}$ the Marquess of Carmarthen. Twelve Dukes appear in person: Norfolk, Somerset, Grafton, Beaufort, Northumberland (Fitzroy), Devonsilire, Shrewsbury, Marlborough, Buckingham (Sheffeld, a personal friend of Pope), Rutland, Montagu, and Kent. In addition, there is the Duchess of Monmoutb, Anne Scott, who was Duchess of Buccleuch (Scottish) in her own right, widowed since the execution of her husband in 1685. The "Duke of Powis" is a Jacobite title. There were only four Marquesses in 1715, and all arc in the list: Lindsey (created Duke of Ancaster later in the year), represented by $\mathrm{S} \& \mathrm{H}$ Lord Bertie; Dorchester (created Duke of Kingston in that year, the leader of Fashion and father of Pope's friend Lady Mary Wortley Montagu); Wharton (Duke of Wharton in 1718); and the Marquess of Powis who held the Jacobite title of Duke. The last is also represented by his daughter the Viscountess (Irish) Carrington. There are 35 Earls in the list, making up nearly half the Earldoms in existence in 1715: they include Derby (hen the premier Earl), Dorset and Bridgewater (both later Dukes), and such powerful frgures as Pembroke, Salisbury, Nottingham, Oxford (Harley, formerly the leading Minister), 
Clare (later Duke of Newcastle and Prime Minister), and Carnarvon (Brydges, later Duke of Chandos). Some are represented by the less familiar titles of their S \& $\mathrm{H}$, such as Holderness, Sandwich, and Scarborough, while Lewis Watson, created Earl of Rockingham in 1714, appears only as "Lord Sondes." The Earl of Portland (later Duke) is represented by the Hon. William Bentinck. Pope's best friends among the Earls were probably Oxford (Harley) and Peterborough (Mordaunt, the great general), but Carnarvon gets a warm mention in the Preface. The list includes five Viscounts and (I think) 34 English Barons, about half in each case. The Roman Catholic Baron Petre who appears in the Rape of the Lock had died in 1713, leaving an infant as successor, but there are two Ladies Petre in the list. "Lord Leimster" is not the Irish Duke of Leinster but a phoneticism for Lempster (i.c. Leomirster); the family name was "Fermor," and there is a distant connection with the Catholic family to which Arabella of the Rape belonged. Lady Mary Caryll, of the Catholic family who were friends of Pope, was the daughter of the Scottish Earl of Seaforth, while one Caryll held a Jacobite title. Pope's Friends also included Barons Bathurst, Lansdowne (Granville, a literary peer mentioned warmly in the Preface), Cobham (Temple), and Carleton (Boyle).

The Scottish peers are far less well represented, mainly because of the small part they played in English political and social life. Because of the high prom portion of peers to population, and to a much poorer population at that, the Scottish peers tended to be relatively badly off, and consequent!y somewhat provincial: many would not have been interested in subscribing to an expensive book like Homer's liad. After the Union there were 16 representative peers elected to sit in the House of Lords: these were usually drawn from the higher-ranking peers and greater landowners, who could afford the expense of an annual journey to Westminster. Three of the eight Scottish Dukes had English titles and consequently non-elective seats in the Lords: Hamilton, Queensberry, and Argyll (the last a friend of Pope). All three are in the list, together with the Duke of Roxburghe. By contrast, none of the Scots Marquesses and only seven of the Earls appear. A very few Scottish peers were Englishmen who were not Scoltish landowners; three of them are in the list, "Lord Cheyne" who ought to have been written as Viscount Newhaven (a Tory politician), Viscount Dunbar (Constable) a Roman Catholic resident in England; and the only Scottish "Lord" in the list, also an English resident, and a Roman Cathoilic, Lord Aston.

Many of the Irish peers were non-resident Englishmen who never intended to set foot in Ireland, but were unable to obtain English pecrages as soon as they wished. The Irish peerages were of lower status than the English, and 
many who had been awarded them as consolation prizes tried to obtain English titles as soon as possible, as Pope's friend the Earl of Burlington had succeeded in doing. Others in the list include Gage, a Sussex baronet whose family became Viscounts Gage; Castlecomer (Wandesford, a Yorkshire squire); and the notorious Ranelagh (Jones) a fraudulent politician who had died in 1712 and was represented by his Countess and by one "Lord Ranelagh" (the last entry is odd, since his heir had apparently not yet claimed the title). But the greater part of the Irish pcerage consisted of the top layer of the English and Scottish landlords, true colonists, who had taken aver nearly all the land of Irejand during the seventeenth century. Some had managed to retire to England to live as absentee landlords, but most remained in Ireland; almost all the resident Irish peers had been members of the Irish House of Commons before their elevation. The only Irish Duke, Ormonde, of the ancient Anglo-Irish house of Butler, a leading Jacobite, was a subscriber; so was his brother the Earl of Arran (Charles Butler, later given the title of "Dike of Arran" by the exiled monarch). The other six Earls were Burlington (Boyle, a friend of Pope, resident of England), Barrymore (an English M. P.), Donegall, Orrery (another Boyle, who like Burlington also had an English title, and figures in the Batzle of the Books), Mountrath or Montrath (who appears as "Montroth"), and Ranelagh. There are only four of the numerous Irish Viscounts and only one Irish Baron, "Lord Brodrick," Lord Chief Justice in Ireland, created Baron in 1715. The test of the lrish peers were probably too provincial and perhaps too uneducated to think of subscribing to an expensive book.

There are hardly any Irish or Scottish Baronets in the list. The English Baronetcy, on the other hand, which was much morc affluent and influential in politics, is well represented by some 50 subscribers (out of a total of some 500 then surviving). Many Baronets had relations in the peerage, and many, as in the list, were M. P.'s Nearly all were substantial landowners, and covered a spectrum from the Sir Roger de Coverley of the day (not a subscriber) to the rich and smart Wyndhams. Among the more interesting names is Sir Richard Grosvenor Bt, head of a family of Cheshire squires dating from the middle ages, Tory M. P.'s for Chester for many generations, and finally Dukes of Westminster and the richest subjects in the kingdom.

Of the "Esquires" in the list a fair number belonged to the landowning gentry. It must be remembered that noble families often had untitled but wealthy and infuential collaterals and relatives by marriage: other families had been large landlords for centuries without sceking titles. Among the considerable squires were Pope's friends the Blounts of Mapledurham and the Carylls. John Bateman's The Great Landowners of Great Britain and Ireland 
gives the names of those who had more than 2000 acres and L2000 a year in 1883; it is striking how many of these families had survived from the early eighteenth century. In fact, many of them werc even older than that: Bateman indicates the landowners who were "either head of, or head of a junior branch of, a family who held land in England since the time of Henry VII in unbroken male line." There are over 300 of these ancient landed families in Bateman, and I have found at least 40 of them in the subscription list, at least 16 of them untitled. New creations in the peerage until the end of the eighteenth century were often made from the old families or from others also as ancient in the female line. This "untitled aristocracy of England" also provided over the centurics a high proportion of the Members of Parliament.

M. P.'s make up a high proportion of Pope's list. If one counts everyone who was M. P. at some time in his life, the figure is at least 200 , or over a third of the total. The occupations of Members of the 1701 House of Commons can be found in Walcot's English Politics in the Early Eighteenth Century, and the brealsdown must have been about the same in 1715: 61 commercial, 48 armed services, and 62 lawyers; the balance of about 300 can be described as belonging to the landed gentry, that is independent country gentlemen, junior members of noble families, or representatives of the nobility. There were also a very few individual $M$. P.'s who da not fit into any of these categories, including the two most distinguished names in the list, Sir Isaac Newton and Sir Christopher Wren, who did Pope great honor. Biographical facts about many M. P. subscribers can be found in Walcott's appendices and in the new History of the House of Commons (ed. Romney Sedgwick), which starts in 1715. Irish peers and the sons of English peers were allowed to become M. P.'s, and about 35 of the peers in the list who were then in the House of Lords had been M. P.'s at some time in their youth. It has been shown that the House of Commons in the century before 1832 was nutmerically dominated by a small group of families, and this must have been true of the previous half-century. These great parliamentary dynasties were headed by the Manners family (Duchy of Rutland), which provided 21 M. P.'s in a century, followed by the families of Cavendish, Finch, Spencer, and Fitzroy, to mention only those in the list, alt but the last being medieval. Of Pope's 165-odd M. P.'s who did not succeed as English peers, I think that 85 were Tory and 70 Whig, the remainder either of uncertain allegiance or impossible to classify (as far I have been able to discover. but I do not feel very happy about these figures). It is also hard to give precise figures for the politics of the peers in the list; but of those who I think deserve to be counted, 76 are Tory and 40 Whig, not all having a seat in the House of Lords. 
That does not, at first sight, look like a great preponderance of Tory over Whig in either House, especially considering that there had been a Tory majority from 1710 to 1714 ; but a closer inspection of the list reveals a decided Tory-Jacobite tendency among the subscribers. In the first place, Pope's Roman Catholic friends and their connexions had subscribed generously. They included the following noblemen and squires: Lord Arundel of Wardour, Lord Aston, Sir Henry Bedingfield, several Blounts and Carytls, Lord Clifford of Chudleigh, Viscountess Carrington, Sir Marmaduke Constable, the Earl of Derwentwater (Radcliffe), Viscount Dunbar, Henry Englefield Esq., Viscount Falconberg (Belasyse), Viscount Montacute or Montague (Browne), the Duke of Norfolk, two Ladies Petre, William Plowden Esq., Thomas Stonor Esq., and Sir John Webb Bt. In 1715 all or nearly all these people were Jacobite in synpathy: they had, or they thought that they had, evcrything to gain and nothing to lose from the teturn of the Stuarss. Derwentwater took part in the rising of 1715 and was executed in the following year, the only subscriber to suffer that fate. Roman Catholics were unable to sit in either House of Parliament or to obtain any position in the public service. They were forced to live privately on their estates and consequently often prospered, nor did they lose the general respect to which rank and wealth entitled them. It was undoubtedly through his friends among the Catholic gentry that Pope was able to make his way into polite society. Upper-class Catholics tended to be carefol, thrifty, and devout; the frivolities of the Rape of the Lock scem out of character, and it is no wonder that some of Pope's friends were displeased by that poem. Among the subscribers were two well-known Roman Catholic priests, the Hon. Henry Charles Howard and Mr. Thomas Southcote ("Mr." was the usual style of a priest at the time). I have omitted from the roll of suspected Jacobites three lukewarm Catholics who conformed in 1715 or shortly afterwards and so were able to enter politics: Sir John Shelley Bt., Sir William Gage Bt. (later Viscount Gage), and Lord (later Earl) Waldegrave.

There are also many Protestant Jacobites in the list. It will not, I hope, be a waste of time to give their names, since they were mostly men of substance, and some were friends of the poet. They include: the Earl of Abingdon; the Earl of Arran (see above); Sir Jacob Astley Bt., M. P.; the Earl of Barrymore, (Irish) M. P.; Viscount Bolingbroke (St. John, Pope's great friend, mentioned in the Preface); Lord Bruce (friend); Lord Bathurst (friend); Peter Bathurst, M. P.; Sir Coppleston Warwick Bampfylde, M. P.; Sir George Beaumont, M. P.; Charles Caesar, M. P.; Mountague Gerrard Drake, M. P.; Sir John Hynde Cotton, M. P.; Sir William Carew Bt., M. P.; John Fownes Esq., M. P.; Lord Gower (Leveson-Gowet, formerly M. P., head of a family which eventu- 
ally rose to the Dukedom of Sutherland); Lord Lansdowne (Granville, Pope's friend, mentioned in the Preface, arrested 1715); Lord Lexington; the Earl of Mar (took a leading part in the Rising 1715, attainted 1716); Lady Masham (Abigail Hill); Lord Montgomery (son of the Earl of Eglinton, who took part in the Rising 1715); Carew Mildmay Esq., M. P.; Lord North and Grey (a Jacobite leader after 1715); the Duke of Ormonde (attainted 1716, joined the Pretender); the Marquess of Powis; Philip Rashleigh Esq., M. P.; the Earl of Strafford (Popc's friend); the Earl of Seaforth (in the Rising 1715, attainted); the Rev. Henry Sacheverell; Sir John Stonehouse Bt, M. P.; Sir Thomas Sebright Bt., M. P.; John Ivry Talbot Esq., M. P.; the Earl of Winchilsea (Finch); Sir William Wyndham Bt, M. P. (friend, and associate of Bolingbroke); Sir John Wodchouse Bt., M. P. I think that the mysterious Lady "Kairne" should read "Nairne," yet another Jacobite family name. These make up a formidable company, notable for wealth, brains, and, until the death of Queen Anne, infuence. The presence of so many Catholic and Protestant Jacobites must have made the subscribers' list look suspicious in the eyes of a keen Whig, atrove all in the year of the Rising. This may explain the most interesting omissions from the list, those of Townshend and Wajpole, the ArchWhigs who were to govern England for many years to come, both coming from wealthy medicval families which had produced many M. P.'s. Ten years later, when the political climatc had changed and Pope had become politically respectable, we find in the subscription list for the Odysscy: "Lord Viscount Townshend, one of His Majesty's Principal Secretaries of State" and the "Right Honourable Robert Walpole, Chancellor of the Exchequer, and the first Lord of the Treasury"-to malce up, perhaps, for their previous lapses they took ten sets each.

I have not yet mentioned the Reverend Dr. Swift, Dean of St. Patrick"s, who did not consider himself to be a Jacobite. Not all Tories wete Jacobites, and quite a few called themselves Hanoverians. The stbscribers' list is certainly Tory in the wider sense, as can be seen from studying the names of the chie: Government supporters in the last years of Queen Anne. Of the Torics on the Iist, apart From Oxford and Bolingbroke, there are Lord Chancellor Harcourt (he and other members of his family were great friends of Pope), Buckingham, Dartmouth, Ormonde, Mar, Strafford, Guildford, and Lansdowne. Of the 12 Tory peers created in a few days around New Year 1712 to give the Government a majority in the Lords, nine are in the list: Bruce, Compton, Paget, Hay ("Lord Duplin"), Bathurst, Foley, Mansell, Masham (spelled "Massam"), and Lansdowne. All this shows how familiarly Pope walked in the Tory corridors of power. But, of course he also had friends among the Whig grandees, 
notably the Duke of Argyll, the Earl of Halifax, and the Duke of Chandos; the last two are mentioned in the Preface, as is a soon-to-be-titled member of the new government of 1714, James Stanhope, Secretary of State, later Viscount Stanhope. Apart from the two notable abstainers, Townshend and Walpole, almost all the great Whig families, the Holdemesses, Rockinghams, and so on, are represented in the list; on the whole they were richer and more elevated than the leading Tory families, although it is indeed a myth that the top aristocracy wore Whig and the lower squirearchy Tory. One of the leading Whig politicians was Joseph Addison, Under-Secretary of State in 1715; another was Spencer Compton, Speaker of the House of Commons.

In 1715 there was still far more money in land than in trade, but some of the "new men," from commerce and finance, are among the subscribers. Sir Francis Child the younger (1684?-1740), M. P., later created Viscoust Castlemain; Sir Robert Furness Bt.; Sir Richard Hoare (of the family who later made Stourhead); and Sir Thomas Davell, M. P., are examples of successful bankers on the list. Other commercial names are those of Sir Justus Beck, the first baronet to be created by George I, and Matthew Decker Esq. Other merchants and their wives are in the list but it is hard to identify them with certainty. There are few sailors but several soldiers, who include (apart from Marlborough and Peterborough) Lieutenant-Genesal Cadogan and his brother Charles, also a general, both M. P.'s and later Barons; and Major-General Wade, later Field-Marshal. The lawyers include three Lords Chief Justices, Forster, Parker (later Earl of Macclesfield), and Whitshed (of Ireland; apart from Brodrick of Ireland). Sir Edward Northey was Tory Attorney-General, and Lord Cowper was Whig Lord High Chancellor. The literary figures are Addison, the Rev. George Berkeley (later Bishop of Cloyne), Cibber, Congreve, Garth, Gay, Hughes, Prior, Steele, Swift, and Anne, Countess of Winchilsea. Music is represented by Pepusch, painting by Charles Jervas, Vanbrugh's name is missing, perhaps for Whiggish reasons. Other interesting names include Barton Booth, joint manager of Drury Lane, and Dr. Hans Sloane, the physician and collector.

The Odysicy subscription list of 1725 is of much the same size and pattern, although many of the names are different. An interesting feature is that some of the great names missing in 1715 are now in the new list: eg. the Dukes of St. Albans, Berwick, Bedford, and Manchester; the Earls of Anglesey, Albemarle, Bristol, Gainsborough (Countess), Huntingdon, Litchfield, Northampton, Stafford, and Tankervilie. These names fill most of the 1715 gaps in the top ranks of the English pecrage, and in addition two Scottish Dukes, Atholl and Montrose, now join the subscribers. There are few notable 
losses, but overall the new subscription list seems to have rather less of a Roman Catholic havour: missing now are the names of Arundell of Wardour, Falconberg, Montacute, Carrington, Dunbar, Engleficld, Petre, and Plowden, On the other hand, most of the Tory-Jacobites of 1715 who were still alive in 1725 subscribed again. The number of M. P.'s rose strikingly to about 250 , of whom, as before, about 35 were then members of the House of Lords. I suspect that Pope's friend Willian Fortescue was active in enlisting West country subscribers of good family, such as three other Fortescues, including Lord Clinton, Viscount Falmouth (Boscawen), Lady Anne Courtenay, Mrs. Rolle, and Thomas Strangways Esq. There are not many more Protestant clergy, but the Archbishop of York (Dawes) gives the new list some respectability. The most notable change is that Walpole, feeling that Pope was now not only politically safe but had even become a national monument, had persuaded his Royal Master and his son to affix their names, so that the list is now headed "The King / The Prince / The Princess." Further on we find the Countess of Darlington, George I's German mistress.

What of the poem which all this display of pride and wealth is designed to promote? Apart from being the greatest poem ever written, Homer's Iliad is appropriate to the age. It is about haughty territorial magnates, who are excessively proud of their genealogies and treat King Agamemnon with scant respect, in a generally Whiggish style. At the end of Book II (lines 586-1071 in Pope's translation) the Catalogue of the Ships describes the contingents from every part of Greece, each with its noble commander, from

The hardy Warriors whom Boeotia bred,

Peneleus, Leitus, Prothoënor led...

to

Last under Prothous the Magnesians stood,

Prothous the swift, of old Tenthredon's blood.

It reads like a subscription list. 


\section{"Condemned to Petticoats":}

\section{Lady Mary Wortley Montagu as Feminist and Writer}

\section{By RoBert HaLsBand}

Lady Mary Wortley Montagu is sufficiently well known so that mention of her name need not be followed by the rhetorical question with which Time magazine headed its review of her Complete Letters-"Lady Who?" I have elsewhere touched on her stature as a lady of letters and on the general predicament of women writers in her time $;{ }^{1}$ her ideas and writings on feminism and her career as a miscellaneous writer deserve re-examination now because they are clarified and amplified in the recently published edition of her wideranging prose and versc. ${ }^{2}$ It may seem anachronistic to call an eighteenthcentury woman a feminist, a word applied to that movement a century later, yet Lady Mary, because of her life-long prenccupation with women as women, their privileges and disabilities, rights and wrongs, deserves an honorable place in that movement.

Lady Mary was an aristocratic, stubborn, and self-educated woman. Her dates, 1689 to 1762 , span the lifetimes of the two most conspicuous ferninist women of the century-Mary Astell (whom she knew) and Mary Wollstonecraft. She is thus one of a trinity of Marys. Unlike the other two she did not enunciate feuninist principles in boldly signed pamphlets and books advocating that cause with revolutionary fervor. Yet she states or clcarly implies this doctrine in her private correspondence with friends and family, and in her essays and poems, whether published or not. As a feminist she earns her credentials also by her vigorous activity in the profession of writing, which in her time was dominated by men. What better proof of women's equality with the other sex than competing on this intellectual battlefield!

Lady Mary's feminist ideas were not static, but became emancipated as she grew older. Whether or not women are inferior to men was a frequently debated question, and often decided on a theological basis. When Lady Mary, at the age of twenty-one, translated the Enchiridion of Epictetus (from a Latin version) and sent it to Bishop Burnet for correction she says this of women: "I am not now arguing for an Equality for the 2 Sexes; I do not doubt God and Nature has thrown us into an Inferior Rank. We are a lower part of the Creation; we owe Obedience and Submission to the Superior Sex; and any Woman who suffers her Vanity and folly to deny this, Rebells against the Law 
of the Creator and indisputable Order of Nature." No doubt her conventional posture was stiffened by her awarencss that the good Bishop was not guilry of holding advanced notions of creatures whose genealogy begins with Adam's rib. (It was he who probably dissuaded the future Queen Anne from endowing the college for women as envisioned by Mary Astell.) Like any sensitive letter-writer Lady Mary tailored her ideas to her correspondents' interests and expectations.

Forty years later, as an expatriate in Italy-when she boasted of being "old without peevislmess, superstition, or slander" "Nature has not plac'd us in an inferior Rank to Men, no more than the Females of other Animals, where we see no distinction of capacity, thô I am persuaded if there was a Common-wealth of rational Horses (as Doctor Swift has suppos'd) it would be an establish'd maxim amongst them that a mare could not be taught to pace." Whether or not women were intrinsically inferior to men was a moot question since they were undoubtedly treated as though they were, especially in their education.

Certainly Lady Mary believed that women were worthy of a more thorough and advanced education than they were allowed; and she proved it by her own strenuous self-education ${ }^{\star}$ as well as by her general prescription. While living in Avignon (in the 1740's) she composed a brief essay in French on the subject of wornen's education. Apparently written only for her own amusement, it is in the form of an imaginary letter to an unnamed literary lady of a past age who now resides in the Elysian Ficlds. At the present time, writes Lady Mary, everything is decided from a political point of view, "and it is by this that I should aspire to prove that learning is very necessary for women." Most women, she continues, "are brought up in such gross ignorance that it is enough for them to mumble some paternosters, in order to believc themselves inspired by Heaven, and consequently worthy of managing everything at home, scorning their husbands and maltreating their servants. I dare boldly say that the behaviour of most women does more harm than good. . . I I attribute this corruption to the bad education which stifies the natural wit of some, and increases the foolishness of others. If men would only see us as an element in the state (for I submit to inferiority ${ }^{T}$ although I could name a thousand who have written, as you know, to prove the equality of the sexes) they ought to strive to use all talents proftably. Our frailty prevents us from serving in war, but this same frailty gives us great leisure for study. Those who succeed will be able to contribute to the Republic of Letters, and those who do not succeed will at least avoid idleness with all its consequenccs."

A few years later, from her Italian retirement, she returned to the subject in 
letters to her daughter. In England, she insists, women are treated with contempr; they "are educated in the grossest ignorance, and no art [is] omitred to stiffle [their] natural reason"-as though, she adds-"the same Studies which raise the claracter of a Man should hurt that of a Woman." "The paradox of this injustice, slue points out, is men's fear that improving the understanding of women would only "Furnish [them] with more art to deceive them, which is directly contrary to the Truth."'"

Ac the same time Lady Mary admitted that excessive slow of learning in a woman could be as undesirable as ignorance; she had always "thought the reputation of learning a misfortune to a woman."1" Indeed, while surreptitiously studying Latin as a young woman she sent Bishop Burnet her translation and acknowledged that the world despised and ridiculed "a Learned Woman. Them words imply . . . a tatling, impertinent, vain, and Conceited Creature." But, she continued, only superficial learning has this effect." Many years later she still believed that a woman of genuine learning should conceal it "with as much solicitude as she would hide crookedness or lameness," for it would draw the envy and hatred of most people. "In her own letters she tactfully adjusted her intellectual exhibitionism to her correspondents: when writing to learned friends like the Abbé Conti and Sir James Steuart, the political economist, she flaunted her erudition, whereas to her daughter and the dull Countess of Oxford she presented herself nerely as a sharp-witted, opinionated woman, rich in common serise and common reading.

These then are Lady Mary's opinions of women's intellect and capacity for education; and they affected her own career and her status as a writer. For, as her French essay on women's education implies, she regarded herself as one who had succeded in her studies and could contribute to what she calls the Republic of Letters. Certainly she was not a professional writer in the sense of one who earns a living by her writing; her wealth and rank made that both unnecessary and indecorous. Furthermore, she repeatedly insists that writing for money can only corrupt that high and noble art, that a mercenary motive debases writing. ${ }^{\text {s }}$ Yet she does not fit Virginia Woolfs caricature of those women who did not write for a living: "shut up in their parks among their folios, those solitary great ladics ... wrote without audience or criticism, for their own delight alone."

Mrs. Woolf admired Aplura Behn as the first professional woman-writer because she earned her living by her writing. ${ }^{14}$ Is that, I wonder, an unqualified definition of professionalism? Or is the money earned only a by-product of literary activity carried out with such talent and dedication as to be "professional" in the sense of artistically accomplished and successful? If a Grub 
Street hackwriter earns his living by churning out mechanical compilations, can he be called a professional writer-as contrasted with such "amuateurs" as Joseph Addison, whose profession lay in Parliament and politics, or Anthony Trollope, whose profession was the civil service ? ${ }^{35}$ I belicve Lady Mary can be regarded as a professional writer although not in the sense of Dr. Johnson's dictun that only a blockhead would write except for money; she was a professional writer in her dedication to that craft throughout her long life. In a recent book entitled Literary Women Ellen Moers cites a nineteenth-century feninist radical who called Ludy Mary the first professional woman writer in England. ${ }^{16}$

But whether she is classified as professional or amateur, there can be no doubt that as a writer she was engaged by feminist topics--that, in other words, she combines both roles of my title, feminist and writer. Her very first publication, in fact, was an essay in the Spectator that satirically treated marriage from a wife's point of view. (She was the only woman, incidentally, who contributed to that periodical.) In June 1714 the Spectator had printed a letter written by Addison in the role of "a tall, broad-shoulderd, impudent, black Fellow ... every way qualified for a rich Widow." He complains that he has been unable to capture a rich widow in marriage because his courtships have been obstructed by the Wtow-Club, made up of "nine experienced Dames" who meet to pool their information about widow-hunters, and are thus able to resist suitors like himself. "Their Conversation," he continues, "often turns upon their former Husbands, and it is very diverting to hear them rclate their several Arts and Stratagems, with which they anused the Jealous, pacified the Cholerick, or wheedled the Good-natured Man, 'till at last, to use the Clubphrase, They sent him out of the House with his Hels foremost."17 In its gentle raillery and condescension Addison's fictitious letter is typical of his attitude toward women in most of his essays.

A month later, Spectator No. 573 printed a reply from Mrs. President, head of the Widow-Club, and it was Lady Mary who had held her pen. "You are pleased to be very Merry, as you imagine, with us Widows," she begins; and then in her counter-attack as well as defence of the club she relates the history of her own extensive marital career: having disposed of six husbands, she intends to take a seventh. (She thus outranks Chaucer's Wife of Bath, who could boast of only five husbands.) Her constant suitor, the seventh husbandto-be, is called the Hon. Edward Waitfort, evidenty Lady Mary's private little joke about her husband Edward Wortley's long and qucrulous courtship. At the end of her account she sums up her marriages: "I do not believe all the unreasonable Malice of Mankind can give a Pretence why I should have been 
constant to the Memory of any of the deceased, or have spent much time in grieving for an insulent, insignificant, negligent, extravagant, splenatick, or covetous Husband; my first insulted me, my second was nothing to me, my third disgusted me, the fourth would have tuincd me, the ffth tormented me, and the sixth would have staryed me. If the other Ladies you name would thus give in their Husbands Pictures, at length, you would sec, they have had as little Reason as my self to lose their Hours in weeping and wailing." head of the essay Lady Mary put a Latin motto from Juvenal that sums up her reply: "Being reproved they bite back." This needs to be kept in mind, for the portrait of the widow is far from idealized; she displays some claracteristics that are less than admirable. Mrs. President shows herself to be both frivolous and mercenary, but her various husbands easily surpass her in their fautts. Lady Mary as a feminist regarded women as human creatures of mixed qualities and not as idealized saints.

She had more opportunity to "bite back" in a periodical that she herself conducted in 1737-38. The chicf mission of her paper, which she called The Nonsense of Common-Sense, was political, as its title implied, for it supported Robcrt Walpole's administration against the Opposition paper Common Sense. Of the nine essays that Lady Mary wrote for her paper during its brief run she devoted two to women-in contrasting ways. Other essays simply glanced at them, like the first paper (in December 1737), where they are urged to wear wool instead of silk in order to support the domestic woolen trade, and the third paper, where they are teased for adoring the reigning castrato singers. ${ }^{10}$

In Number II of The Nonsense of Common-Sense, which deals with women directly, the anonymous Author begins, "I have allways been an Humble $A$ dmirer of the Fair Sex, nay, I beleive I think of them with more tenderness than any Man in the World. [Readers could not have seen the irony here.] I do not only look upon them as Objects of pleasure, but I compassionate the many Hardships both Nature and Custom has subjected them to. 1 never expose the Foibles to which Education has enclin'd them; and (contrary to all other Authors) 1 see with a favourable Eye the little vanitys with which they amuse themselves, and am glad they can find in the imaginary Empire of Beaury, a consolation for being excluded every part of Goversment in the State." But the Author is shocked, the essay continues, to see that the influence of women--specifically "Brittish Mothers, sisters, and mistrisses (for Wives are out of the Question)"-has caused the defeat in Parliament of a bill to reduce interest on government bonds from four to three per cent. Women are urged to forego luxury and self-indulgence in favor of patriotic support of the lower interest rate. ${ }^{20}$ Two elements of this essay are puzzling: the Author presents no 
evidence that women opposed the bill; and the scolding could have no effect since it had been defeated in Parliament eight months earlier. Perhaps Lady Mary, thinking it might be brought forward again, was campaigning carly. Still, the essay assares women that although they may be excluded from a direct voice in government their duty is to use their personal power beneficently when they can.

In Number VI of The Nonsense of Common-Sense, Lady Mary devotes the entire paper to an impassioned and enlightened defence of womankind. After starting as a "Freind ... of the Fair sex," the Author attacks Common Sense for its pernicious advice to avoid plays because they teach immorality and to attend operas instead. Declaring himself opposed to such a dangerous pastime for women, the Aulhor writes: "I am for treatirg them with more dignity, and as I profess my selfe a protector of all the oppressed I shall look upon them as my peculiar care." As a moralist the Author intends to defeat vulgar prejudices, the most universal of which is "that of treating the weaker sex with a contempt, which has a very bad Influence on their conduct"; they are treated as though their reason is weaker than men's-a prejudice that men cling to in order to rationalize thcir own selfish desires. For that reason, a paper that ridicules or declaims against women is very welcone in the coftee-houses, "where there is hardly one Man in ten but fancys he has one reason or other, to curse some of the Sex most heartily."

Wher using a theological argunent Lady Mary does not stoop this time to the humility of her statement to Bishop Burnet many years earlier. "If I was a divine," she writes (as Author), "I would remember that in their first Creation [the beautifull halfe of Mankind] were design'd a Help for the other Sex, and nothing was ever made incapable of the end of its Creation." If men cannot find proof to justify their claim to superiority, they simply invoke the traditional prejudice that only they have been endowed with reason. "I am seriously of another Opinion," continues the Author: "as much greatness of Mind may be shewn in submission as in command." Women's virtue entitles them to the greatest respect because they are cut off from the kind of glory that only men can win; a woman "who has perform'd her Duty as a Daughter, a Wife, and a Mothes, appears to my Eyes with as much veneration as I should look on Socrates or Xenophon, and much more than I should pay cither to Julius Caesar or Cardinal Mazarine. ..." Women are advised to value themselves not merely for beauty but for "rational, sensible" minds that will enable them to make the most estimable figures in life. "Begin then Ladies," the Author concludes, "by paying those Authors with Scorn and contempt who 
with the sneer of affected Admiration would throw you below the Dignity of the Human Species." ${ }^{21}$

In the entire canon of Lady Mary's letters, essays, and poems this is her most extended, articulate, and reasoned defence of women. Compared to the feminist doctrine in the Tatler and Spcctator it is more advanced in its tenets, more forthright in its advocacy, and more vigorous in its expression. It was reprinted almost immediately by the London Magazine for January 1738, which gave it the ambiguous title: "An Apology for the Ladies."

Besides essays in a weekly journal, an earnest propagandist could utilize p:imphlets, especially if the argument could be spun out in elegant verse couplets. (The recently issued bibliography by David Foxon lists the enormous number of verse pamphlets that were published between 1700 and 1750). Lady Mary used this means at least twice for feminist propaganda: once to defend women in general against $\mathbf{a}$ satirist's scorn, and once to set forth her thoughts on courtship and marriage.

Jonathan Swift's The Lady's Dressing Room, published in 1732, vividly depicts how a naif. Strephon explores his Celia's dressing room, with its evidence of siatternly filth (including an unemptied chamber-pot), and steals away disgusted,

\section{Repcating in his amorous Fits, Ol!! Celia, Celia, Celia shits!}

Among the various responses to the poem--it caused Mrs. Pilkington's mother to vomit ${ }^{23}$-four writers issucd anonywous pamphlets; one of them has only recently been identified as being by Lady Mary."' Swift's poem, like others of his "excremental vision," is sometimes cited as proof of misogyny; one may wondcr how a woman writer would treat it. She might scold him for his lack of charity, reprove him for his obscenity, accuse him of undue bias in choosing such a nympla as heroine. Lady Mary does none of these; the title of her poem indicates her strategy: The Dean's Provocation for Writing the Lady's Dressing Roam (1734). She spins out a fiction of how lye had gone to a prostitute. who demanded payment before her services; how when he proved impotent and demanded the return of his payment, the prostitute refused; whereupon he vowed that in revenge he would ruin her trade by describing her dressing room.

In her jen d'esprit Lady Mary very cleverly parodies Swift's own verse style-his octosyllabic couplets, his blunt, unpoetic diction, his digression, animal parallels, sententiae, and even his use of scatological words-as in her concluding lines. The prostitute, refusing to return the money, says: 
Perhaps you have no better Luck in

The Knack of Rhyming than of -

When the Dean replies with the threat that he will describe her dressing-room:

She answer'd short, I'm glad you'll write,

You'll furnish Paper when I Sh-e.

In this poem Lady Mary is not at all lady-like, but why should she be? Although "condemned to petticoats" (as she phrased it) she neither demanded nor expected consideration for being a woman. Is that not the frame of mind fitted for sexunl equality, the "equal opportunity" that feminists strive for today?

Her other feminist poem, published as a pamphlet (in 1733), is about courtship and marriage. ${ }^{2 s}$ It is The Answer to a love elegy (printed along with it) by James Hammond, an impecunious young man who had fallen in love with a young woman at court. In her reply to the man's love-poem Lady Mary, answering for the woman, realistically points out that a marriage without financial safeguards would cause bitter regret for both: the woman would be "a poor Virtuous Wretch for Life"; and as for both: "Love soon would cease to smile, when Fortune frown'd." And so at the conclusion the woman makes a firm resolve not to encourage him:

Whilst other Maids a shameless Path pursue,

Neither to Honour, nor to Int'rest true;

And proud to swell the Triumphs of their Eyes,

Exult in Love frorn Lovers they despise;

Their Maxims all revers' $\mathrm{d}_{3} \mathrm{I}$ mean to prove,

And tho' I like the Lover quit the Love."

In her view of marriage Lady Mary recognizes the stringencies of her social class, where in a successful match financial settements had to accompany love as a protection for the wife (as well as the husband). ${ }^{27}$ At the same time she sharply condemns a purely mercenary marriage, a "Nuptial Sale," and characterizes women who marry for that reason "legal Prostitutes." The phrase had already been used, in slightly different form, by Steele in the Tatler and by Defoe; it was made tamous by Mary Wollstonecraft in $A$ Vindication of the Rights of Woman. ${ }^{28}$ With or without Lady Mary's consent, her printer revealed her authorship by putting on the pamphlet's title page "By a Lady, Author of the Verses to the Imitator of Horace." The printer no doubt hoped to profit by the notoriety of her feud with Alexander Pope. 
Lady Mary had already devoted a long poem to women's disabilities after marriage, to the cruel punishment suffered by wives because of the double moral standard imposed by suciety. In the "Epistle from Mrs. Y [onge] to her Husband," purportedly written by a cast-off wife, Lady Mary criticizes the moral code that permits a husband to commit adultery with impunity yet punishes his wife for the same crime:

Too, too severely Laws of Honour bind The Weak Submissive Sex of Woman-kind.

She then asks:

From whence is this unjust Distinction grown?

Are we not form'd with Passions like your own?

Nature with equal Fire our Souls endu'd,

Our Minds as Haughty, and as warm our blood,

O're the wide World your pleasures you persue,

The Change is justify'd by something new;

But we must sigh in Silence-and be true.".

The eloquence of this pocm seems to reflect Lady Mary's urgent convictions; and whether or not she intended it to be printed, it remained unpublished among ber manuscripts.

Adultery and divore were so common anong those she knew that she once suggested (in a letter to her sister) "a genneral Act of Divorceing all the people of England. You know, those that pleas'd might marry over again, and it would save the Rcputations of several Ladys that are now in peril of being expos'd every day." ${ }^{\text {so }}$ Often in verse as well as in prose she scornfully attacked men's "gallantry," whether in or out of marriage, and particularly cundemned the injustice of punishing or ostracizing women when their seducers were really the guilty ones.

She developed this notion in a long French essay refuting the maxim of La Rochefoucauld that there are some convenient marriages but not delightful (delicieur) ones, On the contrary, argues Lady Mary: the marriage of a man and woman who are in love and who are intelligent and sensible will bring far grcater happiness than any alternative to such a union. "It appears to me a life infinitely more delightful, more elegant, and morc plcasurable," she writes, "than the best conducted and most happy gallantry. A woman capable of reftection cannot but look upon her lover as her seducer, who would take advantage of her weakness to give himself a momentary pleasure, at the expence of her repose, of her glory, and of her life." In a true marriage, by contrast, the wife "must strive to heighten the charms of a mistress by the good 
sense and solidity of a friend. When two persons, prepossessed with sentiments so reasonable, are united by eternal ties, all nature smiles upon them. . . ." But she concludes, realistically, that since two such persons are very extraordinary, it is not surprising that such unions are very rare."

Lady Mary's scattered comtnents elsewhere on marriage may sound cynical, for although she believed that it could lead to Jappiness, as a realist she observed that it rately did. Her own failed marriage was a persuasive example. Her cyoicism was thus the obverse of her idealism. By refuting La Rochefoucauld's genuinely cynical maxim she was reafirming the idealism that she had so fervently set forth in her courtship letters. Her essay on marriage was never ptiblished in her lifetime; instead she allowed friends to read it and to make copies. In this modest private circulation she showed her desire to propagandize in a cause that would benefit women.

How do her ideas on marriage contribute to her advocacy of feminism? The faults of conventional marriage of the time are to the woman's disadvantage-the mercenary principle that treats her as a financial commodity, and the clouble stanclard of morality that permits a husband's infidelity but harshly punishes a wife's. Wonan's lot would be improved, Lady Mary implies, if the institution of marriage were accepted honestly and seriously as a union between equals.

All of her writings that I have so far discussed illustrate both parts of my title simultaneously: her ideas on feminism and her activity as a writer concerned with those ideas. But in most of her writings she did not confine herself to that subject; she stands out as a woman whose literary energy and passion drove her to compete in an activity ruled by men. She is thus a feminist in practice.

In The Nonsense of Common-Sense, which I have already mentioned for its feminist arguments, her main role is political. Assuming the persona of an impartial commentator, she argues for sincere moderation instead of blind partisanship. She then ridicules the Opposition's bellicose attitude toward Spain as well as their complaint that freedom of the press is being threatened : $^{\text {2y }}$ in effect she supports the Walpole administration. On more general issues, she preaches in favor of "Virule and good sense" and against obscenjty, cynicism, and impudence in English society and writing. ${ }^{3 s}$ It is doubtful that her reformist zeal in morality was any more effective than her political moderation, for her essays did not win many readers for The Nonsense of Common-Sense. Each number of the paper bore the notice: "To be continued as long as the Author thinks fit, and the Publick likes it." Because the public apparently did 
not like it, the Author thought fit not to continue, and the ninth number was its last.

The most striking of her political essays, however, remained unpublished. She entitled it "An Expedient to put a stop to the spreading Vice of Corruption," Since the Opposition to Walpole's administration vociferously exclaimed against his Parliamentary corruption, she writes, the best method to cure it would be to abolish Parliament and let the King rule through his ministers, who would then have no Members of Parliament to corrupt. ${ }^{3 .-1}$ This highly seditious "Expedient" was obviously unpublishable, for its printer and author (if known) would be in danger of arrest and prosecution.

A clear contrast between Lady Mary as a private individual, hemmed in by the conventions of her sex and social class, and as a public-spirited, vociferous propagandist appears in her activity during the controversy over smallpox inoculation. Privately, after she had observed the operation in Constantinople in 1717, she had it performed on her son, and later on her daughter in London. As the operation became popular, she was "so much pull'd about and solicited to visit people," she complains to her sister, "that I am forc'd to run into the Country to hide my selfe." In the previous autumn (1722) she had written and published in a newsaper an article from a fictitious mercliant in the Turkish trade describing the operation and staunchly defending its efficacy. So violent was her attack against those physicians who oprosed or malpractised the opcration that the newspaper editor cautiously toned down her sarcasm and indignation. In the guise of the Turkey merchant she insists that her only motive in addressing the public is "the private satisfaction of having done good to Mankind." ${ }^{34}$ If the essay had really been written by a metchant he would perhaps have revealed his identity; Lady Mary dared not, but neither could she repress her determination to speak out in the public forum.

Her reasons for bursting into print were not always so altruistic. For although she once asserted that revenge was a pleasure forbidden to women, ${ }^{87}$ she indulged herself in that rather grim pleasure by attacking the foremost verse satirist of the age.

During his long, contentious career, Alexander Pope endured many attacks, mainly from Grub Street; few if any possess the bitter brutality of Verses to the Imitator of Horace (1733), a satire in which Lady Mary was assisted by Lord Hervey. The title-page of one version calls its author "A Lady" and London gossip certainly knew who was meant. Perhaps Lady Mary launted her authorship in the hope that public revenge on Pope would neutralize the scandalous reputation he had fastened on her with his satires. In this masculine world-for no other woman fought in the war of poisonous couplets ${ }^{8 B}-$ Lady 
Mary stands out as a fearsome lampoonist; and the super ficial notion of women as sensitive, delicate creatures perishes under the impact of her contse and strident couplets. No other pamphletect could match the final lines of Verses:

But as thou hate'st, be hatcd by Mankind,

And with the Emblem of thy crooked Mind,

Mark'd on thy Back, like Cain, by God's own Hand;

Wander like him, accursed through the Land. ${ }^{30}$

I have thus far sketched Lady Mary's activities as a writer of periodical essays, a newspaper article, and verse pamplilets. But what she put into print constitutes only a small part of her literary work. The reason so much of her writing remained in manuscript, I suggest, ts related to the discouragement that women writers suffered through the pressure of social forces. Chronology will help explain Lady Mary's disadvantage. Since her active literary career was terminated by her departure from England in 1739 to begin her long expatriation, she could not profit by the increased tolerance for women writers that developed in England in the second half of the century. Whereas such a paragon of respectability as Hannalı More could achieve phenomenal success as a playwright (in 1778) without the slightest blemish to her reputation, in the early decades of the century women playwrights like Mrs. Pix and Mrs. Centlivre earned, along with money, unsavory reputations and social ostracism.

This may have been the reason why Lady Mary suppressed her single dramatic work, a three-act comedy that she entitled Simplicity. ${ }^{10}$ Her manuscript fair copy of the play, undated and with no indication of source, was apparently never published or staged. It is actually a translation-adaptation of Le leu de lamout et du hasard by Pierre de Marivaux, first staged in Paris in 1730, printed the same year and reprinted in 1732. When a French company of actors visited London in the autumn of 1734, they performed it several times at the Little Theatre in the Haymarket. Lady Mary probably saw it there, gor hold of a copy, and set to work.

Simplicity is something between a literal translation and a free adaptation of the French original. Where Marivaux sets his play in Paris, Lady Mary locates hers not in London, the equivalent, but in rural England, a change that makes the plot about four disguised characters more credible by isolating them in the country. She also anglicizes the names of the characters. converting them all, including several borrowed from the commedia dell'arte, into plain English ones. Her version has one important change in the plot. In Marivatux it is the heroine who suggests to ber father that she disguise herself as her traid in order to test her suitor; and he agrees; in Lady Mary's more convincing 
version it is the father who suggests the ruse because he already know's that her suitor will arrive disguised as his own valet. And where Marivaux ends his play with a witty remark by the valet, after which the company breaks into dance, Lady Mary ends hers more soberly with a sententious comment in prose and verse by the heroine's father, the same device, incidentally, used by Richard Stecle in his popular sentimental comedy The Conscious Lovers (1723).

Lady Mary's most pervasive changes appear in the dialogue. She approaches the French text with both respect and freedom, translating verbatim when the French idiom and rhythm have English equivalents. Occasionally she conflates separate speeches, transposes a speech from one character to another, or adds and deletes bits of dialogue. In tone, her changes transform Marivaux's subtle and delicately sentimental style (marivaudage) into rołsust, practical English. The most striking example of this transformation is the crucial scene of the play: when the suitor reveals his true identity, the heroine says in an aside, "Aln, je vois clair dans mon coeur" (Ah! I see clearly into my heart.) How does Lady Mary translate it? "My Life is sav'd."" Altogether, about one quarter of the dialogue in Simplicity is original; about one quarter is literally translated and about one half freely adapted. Yet not a single sentence or phrase sounds like a translation; nowhere does it betray a foreign origin. In its own right Simplicity wins adniration-not merely as the only English version of the play made in the eighteenth century or as proof of Lady Mary's versatility but as a worthy example of English dramatic literaturc.

She had long been interested in drama. Before Joseph Addison's tragedy Cato was presented on the stage or printed, he loaned it (in manuscript) to Lady Mary's husband, his close friend; and Wortley in turn asked his young wife to write a critique of it. This she did, with a carefully composed essay analyzing, in traditional sequence, the plot (or fable), characters, sentiments, and language. ${ }^{42}$ Her firm, confident tone is unexpected for a young woman whose litcrary ambition had not as yet found any outlet. But her concluding sentence, addressed to her husband, is becomingly modest: "I have now gone through the Task you enjoyn'd me, in as short a manner as I could, which I cannot excuse undertakeing (being so much above my skill) but by remembering you, that it was by your Command." Wortley evidently let Addison read the critique, for-as can be seen in the published text of the play--Addison accepted many of Lady Mary's suggestions for improving the diction. But his most telling response to the essay can be seen in Lady Mary's tubric: "Wrote at the Desire of Mr. Wortley, suppress'd at the desire of Mr. Adison." From other sources, we know that Addison was bypersensitive to criticism. ${ }^{4 "}$

What would have been the fate of the essay, we may wonder, if it had not 
been suppressed? The spectacular popularity of Cato in 1713, based in part on its relcyance to England's political situation, stimulated at least four writers to publish critical pamplilets on the play the same ycar. Ladly Mary's essay could have been added to that number, perhaps, had she been a man and willing to disregard Addison's "desirc." But as a dutiful wife, she submitted. In the latter half of the century (in 1769), if we seek a parallel, the blue-stocking Elizabeth Montagu published with considerable pride her essay on Shakespeare. Lady Mary's critique of Cato remained among her manuscripts, unknown and unpublished, until the present century.

In still another kind of prose-historical memoirs-she again had to be content with writing for her own satisfaction. Historical memoirs are rarely published in the lifetime of their authors-Horace Walpole's not until after his death, Lord Hervey's not until a century after his. Lady Mary's brief account of the court of George the First on his arrival in England (in 1714) is a brilliant exercise in the art of historical memoir; had a morc substantial amount survived she would strely rank with Walpole and Hervey. In her fragment, although she too easily accepted gossip for fact (especially if it was scandalous), her analyses, particularly of individuals, are keenly observed and acutely set down. "The King's character may be compriz'd in very few words" she writes. "In private Life, he would have been call'd an Honest Blockhead; and Fortune that made him a King added nothing to his happyness, only prejudice'd his Honesty and shorten'd his days." Of the arrogant Prince of Wales (later George the Second): "he look'd on all the Men and Women he saw as Creatures he might kick or kiss for his diversion"; and of the Princess Caroline: she "Trad that Genus which qualify'd her for the Government of a Fool and made licr despicable in the Eyes of all Men of Sense: I mean a Low Cunning which gave her an Inclination to cheat all the people she convers'd with and often cheated her selfe in the first place..." glitter with hard wit, are typical of the entire fragment. It would be difficult, if not impossible, to point to any woman writer (Fanny Burney was a diarist, not a memoirist) who wrote court memoirs with such talent-though I am tempted to say genius-for historical portraiture.

With all these varied writings, in prose and in verse, published and in manuscript, Lady Mary would seem to deserve a place in the Republic of Letters. Yet I have not mentioned the Turkish Embassy Letters, her most ambitious work, and one which-surrounded as it is with ironies, puzzles, and paradoxes-won her a substantial European reputacion as a woman of letters. She composed these letters during her journey to Turkey and residence there, an experience unique for a woman writer. As a young wife, she had accom. 
panied her husband, British Ambassador to Turkey in 1716, remaining only sixteen months because Wortley bungled his diplomatic mission so disastrously that he was recalled. But Lady Mary succeeded brilliantly in her unannounced, sclf-appointed mission of interpreting Moslem culture for Western Europe.

The status of Turkish women could not fail to pique her curiosity, for Western Europe had always been intrigued by a society in which polygamy was practiced and women were confined to the harem, unseen by any men except their husbands and attendant eunuchs, As the first woman traveller in Turkey to record what she saw of her own sex Lady Mary ser down particularly trustworthy and vivid observations. After visiting a women's bagnio in Adrianople and joining them in their bathing, she reported that at this social gathering women behaved with modssty, grace, and good manners. She also found that women of the upper class, whom she visited in their palaces, were as charming and sophisticated (and of course beautiful) as any court-ladies in London or Paris.

Implicitly, as well as explicitly, she opposes the idea current in Europe that Turkish women were abject slaves, deprived of all rights and privileges. Aaron Hill's popular book on the Ottoman empire (in 1709) emphasized women's inferior position and the complete subjection of wives, who-he states-had no liberty at all; and the travel-writer Dumont bluntly states that "There is no Slavery equal to that of the Trerkish Women." "1s Such opinions seem based not on open-minded observation but sather on the misconception that women confined to the harem were bereft of all rights. Instead, Lady Mary develops the paradoxical notion that Turkish women enjoy more liberty than westers women, for when they go out in public they cannot be recognized, even by their own lusbands, bccause their shapeless garments hide their features from head to toe. "This perpetual Masquerade," she writes, "gives them entire Liberty of following their Inclinations without danger of Discovery." In addition to this personal liberty-for which, she adds, their religion does not threaten them with punishment in afterlife-Turkish women have the privilege of owning property and money; and if divorced they receive additional support from their husbands. "Upon the Whole," she concludes, "I look unon the Turkish Women as the only free people in the Empire."

The Turkish Embassy Letters, which Lady Mary compiled in Turkey or soon after she returned to England, increasc her stature as a ferminist for other reasons. When she loaned the manuscript of the letters to Mary Astell (in 1724) that pioneer saw it as a formidable challenge to the supremacy of men writers, and prefixed to the manuscript a verse tribute to its author that begins: 
Let the Male-Authors with an envious eye

Praise coldly, that they may the more decry:

Women (at least I speak the Sense of some)

This little Spirit of Rivalship o'recome. ...

In her prose preface Mary Astell continues: "I confess I am malicious enough to desire that the World shou'd see to how much better purpose the Ladys Travel than their Lords. ..." Although she had tried to persuade Lady Mary to publish the manuscript, Astell regretted that the "most Ingenious Author has condemn'd it to obscurity during her Life. . . However, if these Letters appear hereafter, when I am in my Grave, let this attend them in testimony to Posterity, that among her Contemporarys one Woman, at least, was just to her Merit."

What did happen to the manuscript? Lady Mary retained it, along with her other writings and her library, during her long expatriation; and then on her way back to England (in 1761) she presented and inscribed it to an English clergyman in Rotterdam "to be dispos'd of as he thinks fit." She obviously instructed him to have it published, for if she had intended it to be returned to her family she would simply have kept it with her other possessions. Eight tnonths later she died, and the clergyman, in exchange for a large reward, presented the manuscript to her daughter, the Countess of Bute. But it had already been copied, mysteriously; and when the letters were published the following year (without her family's permission) the title page proudly proclaimed that they were by "the Right Honourable Lady M-y W--y M-ce."

This progress of the Turkish Embassy Letters from their origin to their publication charts the evolution of Lady Mary's career as a feminist and writer. In their earlier form they were private correspondence with friends and family; she then arranged them to make a collection to be read and admired by her private circle of friends, including (as we have seen) Mary Astell; and finally, she arranged for their publication so that although decorum forbade her practising the trade of authorship, their posthumous appearance would establish her status as a liberated woman not inferior to men in the Republic of Letters.

Even from beyond the grave Mary Astell hoped to pay tribute to her friend. Shortly before her death in 1731, after a serious religious discussion. with Lady Mary, she pauscd and earnestly said, "My days are numbered: I am old; that you know; but I now tell you in confidence, I have a mortal disease which must soon bring me to the grave. I go hence, I humbly trust in Christ, to a state of happiness; and if departed spirits be permitted to re-visit those whom they have loved on arth, remember I make you a solemn promise that mine 
shall appear to you, and confirm the truth of all I have been saying." Mary Astell's apparition presumably never came to Lady Mary. Now-two hundred and fifty years later-the two wonen have been reunited-have they not i-under the aegis of the feminist movement.

\section{Notes}

1. "Ladies of Letters in the Eighteenth Century," Sttant and Georgin Moments, Clark Library Seminar Papers on Seventeenth and Eighteentis Century English Iiterature, ed. Earl Miner (Berkeley, Jos Angeles, London: Univ, of California Fress, 1972); "Wonen and Literature in Eightecnth-Century England," Eightecnth-Centwry Woman, Transattions of the McMaster Associattion Ior Eighteenth-Cenlury Studies (Toronto: Hakkert), IV (1976).

2. Essays and Poems and Simplicity, a Conedy, ed. Robert Halsband and Isobel Grundy (Oxford: Clarendon Press, 1977). Hereafter cited as Essays and Poems.

3. Lady Mary Wortley Montagu, Complete Letters, ed. Robert Halsband (Oxford: Clinendon Press, 1965-7), I, 45. Herenfter cited as Letters.

4. Ibid., III, 302.

5. Ibid., III, 27.

6. Robert Halsband, The Life of Lady Mary Wontley Montagu (Oxford: Clarendon Press, 1956), pp. 5-8.

7. In plysical qualities, as her txampie ("serving in war") makes slear.

8. Essays and Poems, pp. 392.93.

9. Letters, IIt, 40, 26. A sinithr iden can be found in, among others, Letitia Pilkington, Memoirs 1712-50, exd. T. Isates (London: Rourledge and Sons, 1928), pp. 81-82; and Somuel Johnson in Janzes Buswell, Life of fohnswon, ed. G. B. Hill and L. F. Powell (Oxford: Clarendon Press, 1934-50), V, 226.

10. Letters, III, 217 ,

11. Ibid., I, 45 .

12. 1753, ibid, III, 22.

13. Ibid., 68.

14. A Room of One's Oum (London: Hogarth Press, 1954), p. 95.

15. ef. William Haley. "Amatcurism," The American Scholar, 45 (1976), $253-59$.

16. (New York: Doulicday, 1976), p. 21.

17. The Spectator (No. 561), ed. Donald F. Bond (Oxford: Clarendon Press, 1965), IV, $515-16,518$.

18. No, 573, ibid., IV, 556-61.

19. Essays and Pocms, pp. 107, 117.

20. Thid., pp. 109-11.

21. Ibid., pp. 130-34.

22. Memoirs p. 416 .

23. Rohert Holshand. "'The Lady's Dressing Room' Explicated ly a Contemporary," in The Augustan Milicti: Essays Presented to Lousis A. Landa, ad. H. K. Miller, E. Rothstein, G. S. Rousseau (Oxford: Clarendon Press, 1970), pp. 225-31. Lady Mary's manuseript version is printed in Essuys and Poems, pp. 273-76.

24. Letters, III, 219.

25. Many othcr prems by Lady Mary treat ferninist topics. I deseribe here the only twon that were published is pamphlets. For the others, see Index to Exsays and Poems.

26. Essays and Poems. pp. $270-72$.

27. Ironically, Lady Mary herself had eleped in $\mathbf{1 7 1 2}$ withour any financia! settlement, but Wortley was a wealthy man.

28. Tatler No. 91 ( 8 Nov. 1709); C. J. Rawson, "The Phrase 'Legal Prostitution' in 
Fielding, Defoe and Others," Notes and Quaries, 209 (1964), 298; Wollstonecralt, Vindication (2nd ed. 1792; repr. Gregg, 1970), p. 128.

29. Essays and Poems, pp. 230.32. In 1759 she copicd a passage from the poem in a letter (Letters, III, 219). For a full discussion of this jrem, sec Isobel Grundy's article in RES, n.s. 23 (1972), 417-28.

30. Letters, II, 52.

31. Essays and Poems, pro, 389-90, 389.

32. Ibid, pp. 116-17, 129.

33. Ibid., pp. 135-40, 146-49,

34. Ibid., Tp. 100-04.

35. Lettets, II. 26.

36. Essays and Poems, p. 95.

37. Letters, III, 219.

38. J. V. Guerinot, Prmphlet Atacks on Alexander Pape 1717-1744 (Landon: Methuen, 1969). Other anonyrnous attacks by women, if iny, have not been identified.

39. Essoys and Poems, pp. 265-70. For it full discussion of this poem, see Isobel Grundy in "Verses Address'd to the Imitator of Horace: A Skirmish between Pope and some Persons of Rank and Fortune," SB, 30 (1977), 96-119.

40. Essays and Poems, fp. 316-79.

41. Ibid., p. 357.

42. Thid, एp. 62-68.

43. For details, see Robert Halsband, “Addison's Cato and Lady Mary Wortley Montagu," PMLA, 65 (1950), 1122-29.

44. Essays and Pocms, pp. 86, 93. In some verse she sent to Lord Hervey (1734), she has this delightful couplet about Queen Caroline: "Superior to her waiting Nymphs, 7 As Lobster to attendant Shrimps" (Letters, II, 99).

45. Aaron Hill, A full and just Account of the Present State of the Ottoman Empire (London, 1709), p. 97; Jean Dumont, $A$ New Voyage to the Levant, 4th ed. (London, $1705)$, p. 268.

46. Lettew, I, 328-29.

47. Letters, I, 466-67.

48. Lady Lotisa Stuart, "Biographical Avecdotes," Essays and Poems, pp. 34-35. This dialogue must have beter reconstructed from Lady Bute's recollection by Lady Louisa, her daughter and confidante. 


\section{"A Turn of Thinking": Benjamin Franklin, Cotton Mather, and Daniel Defoe on "Doing Good"}

By GILBERT D. McEwEN

James Franklin, publisher of Boston's radical New-England Cotrant, was put in jail for a time in 1722 on a trumped up charge, and his brother Benjamin, then sixteen years old, had to run the paper. Even before that happened, Benjamin, eager to join the fray, slipped a satirical letter of his own composition under the printing shop door at night. His brother liked the anonymous contribution and printed it on 2 April 1722; in due course he received thirteen more, the last of which appeared on 8 October of the same year. ${ }^{1}$ These letters purported to come from a middle-aged widow named Silence Dogood, the first in American letters of a long line of satirical yet well-wishing commentators on the passing scene. Mrs. Dogood's name came from a manual of conduct first published in 1710 by Cotton Mather and entitled: Bonifacius, AN ESSAY Upon the GOOD, that is to be DEVISED and DESIGNED, BY THOSE Who Desire to Answer the Great END of Life, and to DO GOOD While they Live:"

The Reverend Cotton Mather has been traditionally regarded as a perfervid preacher, proud cven of his own humility, and with his life and opinions inextricably bound up with the Salem witch hunt. Bonifacits, although not lacking in fervor or in sell-regard of a very special sort, presents another side of its author's persomality, an understanding of which goes far to explain Franklin's interest in the book beyond its help in naming the widow Dogood. In his preface Mather urges apon the reader for his own sake "an unfainting resolution to do good, and an whwearicd woll-doing." "The first chapter, "Essays to Do Good," suggests at some length that one devote as much time and energy to devising good for others as to devices "for our own secular advantage." "Without abridging yourselves of your occasional thoughts on the question, often every day, What good may $I$ do?, state a time now and then for more deliberatk thoughts upon it." Here may have been the germ of Franklin's famuus "Project of arriving at moral Perfection" the last item set down in his memoirs in 1771 . One recalls that his second virtue to be cultivated systematically, next to temperance, was silence."

Following chapters on duty to oneself and duties to home and neighborhood, Mather got down to the particulars that fill the rest of the book: ways 
of doing good to be practiced by ministers, schoolmasters, church members, magistrates, physicians, rich men, officials and lawyers, and reforming societies. In an appendix he discussed efforts past and present to convert the Indians of Massachusetts. The greatest emphasis was placed upon particular ways of doing grod in various professions and walks of life, but with little attention to the sort of people who would be enjoying Silence Dogood a dozen years Jater on.

Mather's clarily of organization may be a reflection of his uncommon mastery of science and mathematics. In its style, however, there is much of the pulpit in Bonifacius, along with an immense amount of learning not very well concealed. It is very different from anything Franklin ever wrote, but its practical approach to good works undoubtedly made a lasting impression upon him.

Mather addressed his reaclers much as he must have his congregation, in the hortatory mode; but Silence Dogood is satirical. Franklin's supposed debt to Addison and Steele has often been cited in his development of a character who stands a little aside from the world, who has no family ties, who cultivates her own garden, who visits with her neighbor, Rusticus, and her minister and boarder, Clericus, and who has some education. Orphaned while young, slee was educated by her master, a country minister, whose library was "small, yet... well chose, to inform the Understanding rightly, and enable the Mind to frame great and noble Ideas."

There is truly a resemblance to the Spectator, and also a similarity in using generalizations to introduce a subject: ". . nothing is more common with us Women, than to be grieving for nothing, when we have nothing elsc to grieve for";" "Histories of Lives are seldom entertaining, unless they contain something either admirable or exemplar," this being Mrs. Dogood's reason for describing herself only briefly. But her discourse is much sharper than Sir Roger's or Will Wimble's, and in the first few letters especially, serves to express a woman's critical point of view. "I have likewise," she writes in the second letter, "a natural Inclination to observe and reprove the Faults of others, at which I have an excellent Faculty."'

It does seem renuakable that a sixteen-year-old printer's apprentice would choose a female character to voice his opinions; perhaps his greatest wislt was simply to break into print by creating such an arresting character as the plainspoken widow. The first letter was a successful audition, showing how well he was able to sense what the readers of the Courant would not only tolerate but actually enjoy. He had already recognized the rational bent of James Franklin and the half dozen "ingenious Men" who supported him in opposing the rest of the town. ${ }^{11}$ After establishing Mrs. Dogood's character in the first three letters, Franklin entered freely into controversy with somewhat less concern 
for the appropriateness to his character of all the utterances that issued from her.

There are some good clues in the Autobiography as to what influences were at work when Franklin first set about writing satire. Sometime in 1784 he returned to work on the manuscript of his memoirs that he had begun in England in 1770-71. He was in France, even farther away from his papers than formerly, and reliant upon his memory. At seventy-cight, and after all his experience at home and abroad, the result was bound to be artful and not necessarily completely faithful to the facts. Recent research which included careful examination of the autograph manuscript of the Autobiography in the Henry E. Huntington Library has thrown new light on its composition. ${ }^{12}$ The paragraph concerning Franklin's early reading, always treated heretofore as a reminiscence set down all at once, had actually three stages.

In the currently standard text it reads:

From a Child I was fond of Reading, and all the little Money that came into my Hands was ever Jaid out in Books. Pleas'd with the Pilgrim's Progress, my first Collection was of John Bunyan's Works, in separate little Volumes. I afterwards sold them to enable me to buy R. Burton's Historical Collections; they were small Chapmen's Books and cheap, 40 or 50 in all. My father's little Library consisted chiefly of Books in polemic Divinity, most of which I read, and have since often regretted, that at the time when I had such a Thirst for Knowledgc, more proper Books had not fallen in my Way, since it was now resolv'd I should not be a Clergyman. Plutarch's Lives there was, in which I read abundantly, and I still think that time spent to great Advantage. There was also a Book of Defoe's, called an Essay on Projects, and another of Dr. Mather's, call'd Essays to do Good which perhaps gave me a Turn of Thinking that had an Influence on some of the principal future Events of my Life. ${ }^{13}$

"Pleas'd with the Pilgrim's Progress ... to a great Advantage" was written in 1770-71. In 1784 or later, "There was also a Book . . . Events of my Life" was added in the right-hand matgin; but "and another ... Essays to do Good" was written in between the first and second lines of the addition in which only Defoe had been mentioned at first. An anbiguity results as to which of the two books gave Franklin "a Turn of 'Thinking," but that is somewhat relieved by an echo of the phrase, found in a letter Franklin wrote from Passy in 1784, to Samuel Mather, the son of Cotton Mather:

When I was a boy, I met with a book, entitled "Essays to do Good" which I think was written by your father. It had been so little regarded 
by a former possessor, that several leaves of it were torn out; but the remainder gave me such a turn of thinking, as to have an influence on my conduct through life; for I have always set a greater value on the character of a doer of good, than on any other kind of reputation; and if I have becn, as you seem to think, a useful citizen, the public owes the advantage of it to that book. ${ }^{14}$

The word "conduct" in the letter shows more specifically than "principal future Events" why Franklin rcmembered Matlicr"s book so warmly. In effect, the marginal additions to the memoirs broadened the definition of "doing good" to fit Franklin's experience.

Mather had addressed the members of various professions, although a reader who belonged to none of them might apply to himself whatever seemed appropriate. Defoe's Esiay on Projects (1697) was addressed to public concerns rather than to persons: banking, credit, bankruptcy, poverty and unemployment, the place of women, the mentally incompetent, and recruiting a navy in wartime. For Defoe, the expected results would benefit the public, on the Lockean ground that what benefits one class of deserving people will uitimately benefit all. (In legard to wagering, however, Defoe leaned toward Mandeville's theory of "private vice, public benefit.") Franklin, a nominal Presbyterian himself although seldom an enthusiastic churchgoer, was paying tribute along the margin to a Boston and a London Presbytetian, both of whom had been nurtured on such works as Richard Baxter's How to Do Good to Many: or, the Publick Good is the Christian's Life. Dirctions and Motites to $\mathrm{lt}$ (1682). One cannot help wondering whether Franklin kncw that Mather and Defoe had themselves been corresponding. Mather recorded in his Diary on 20 May 1711:

Having some epistolar Conversation with Mr. De Foc, I would in my Letters unto him, excite him to apply himself unto the work of collecting and pablishing an History of the Persecutions which the Dissenters have tindergone from the Ch(urch) of E(ngland). And give him some Directions about the Work. It may be a Work of manifold Usefulness. ${ }^{10}$

The picture of Mather exciting Defoe to apply himself intensifics our appreciation of the differences between the two. Both Defoe and Mathor had a strong sense of duty, but their respective notions of carrying out the moral imperative were quite different. Mather lived in an increasingly beleaguered citadel of Calvinism; Defoe was in the thick of the fight on the plains. Mather was far more open with his readers than Defoe, whose character was elusive, 
his disguises many. In his own self-portrait in his old age, however, Franklin appears much closer to Defoe in his concerns, but seldom without an undertone of emotion, in a low key but still not unlike Mather's.

Although Franklin's two models were somewhat alike in their sense of duty, their writing would not easily be confused. Commenting in the Autobiography upon his old favorite, John Bunyan's way of writing, Eranklin also tells what he found attractive in Defoe's works:

Honest John was the first that 1 know of who mix'd Narration and Dialogue, a Method of Writing very engaging to the Reader, who in the most interesting Parts finds himself as it were brought into the Company, and present at the Discourse. Defoe in his Cruso, his Moll Flanders, Religious Courtship, Family Instructor, and other Pieces, has imitated it with Success. And Richardson has done the same in his Pamela, \&c. ${ }^{18}$

Franklin's view of literature was not historical. He probably did not think of Bunyan's works as literanure any more than most of his contemporaries, and was simply remarking that Bunyan's novels had introduced to him the engaging method of writing that mixed narration and dialogue. But he was interested all his life in method of presentation, using "method" as Defoe did, interchangeably with "style" in discussions of writing.

Two of the four works of Defoe that Franklin mentioned are not fiction, but conduct manuals, in the same category with Bonifacius; although the novels are mentioned first, the presence in the list of the Family Instructor and Religious Courtship is of greater importance, for their dramatization of ideas was muck less to be expected. The Family Instrtuctor, published seven years before the Dogood letters, makes such extensive use of dialogue that in his preface to the second edition Defoe says the design of the work caused some to call it "A Religious Play."

It would more have answered that Title, had the Author's first Design been pursued, which was to have made it a Dramatick Poern: But the Subject was too solemn, and the Text too copious, to suffer the Restraint on one hand, or the Excursions on the other, which the Decoration of a Poem would have made necessary.

Never sympathetic to the theatre, Defoe added: "The Author wishes, that either all our Plays were as useful for the Improvement and Enteriainment of the World, or that they were less encouraged."

Defoe, the complete journalist, wrote very frankly about bis method in the 
Family Intructor: "Truths written in the divinest Stile in the World, would be flat, stale, and unpleasant" without some novelty in their presentation. If his "mean and familial Method" should prevail after all the pains of "ministerial Labour and Instruction ... this will be a happy Undertaking, and at the same time be no reproach at all to the Labours of others." ${ }^{m 8}$ His method was to make the child the inquirer, asking questions that were natural and rational, consistent with principle and proper to a child:

The Author has endeavor'd to produce the Questions with an Air of meer Nature, Innocence and Childhood; yct such as being naturally aclapted to the general State of Things, may be apposite and direct:...

The Clild is supposed to come up to such Years as to be thinking and inquiring; suppose about five or six Years old; . . . our little Child asks but very little of his Father, but what a Child at that Age may be very capable of asking."

The father, whose religious affiliation Defoe kept indeterminate, is brought by the child's ingenuous questions to a realization of his own ignorance and weakness of faith.

Religious Courtship was even less likely than the Family Instructor to be forgotten by Franklin. First published on 20 February 1722, , probably too late to have influenced the Dogood letters, the work was chosen in 1729 by Samuel Keimer, for whom Franklin had been a journeyman printer in 1723, to help fill the pages of his new Universal Instructor and Pennsyluania Gazctte. The newspaper, begun by Keimer to forcstall the plans of Franklin to begin his own, had as its largest ingredient excerpts from Chalmers' Cyclopaedia. When Keimer blunderingly printed the entry on abortion, ${ }^{21}$ Franklin once more invented women characters to satirize the hapless printer. Using the names of "Martha Careful" and "Celia Shortface," he published letters in Andrew Bradford's American Weekly Mercury protesting Keimer's "indecencies." As "Busybody" in the Mercury, Franllin continued to nip at his much older rival. ${ }^{29}$

Installments of Religious Cowtship began in "NUMB. XVIII ... The 24th of the $2 \mathrm{~d}$ Month, 1729," with the following notice: "In Order to make our Paper more useful, we shall henceforward publish a scarce and delightful piece of History called Religious Courtship, which more especially regards young People." Each succeeding issue contained an average of two and a half columns, or about eight pages from Defoe's book. Each issue broke off at a point of suspense with "To be continued in our next." Number XXY added the titillating " $" .$. and in a few Papers this will be a diverting, if not a surprizing Story." Religious Contship was continued in larger type in Number XXVII, 
after Keimer had been forced to miss publication for two weeks. By 28 June 1729 (Numler XXXV) lie had reached page 86 in the text he was working from, about a fourdh of the way through the volume. There were no more after that. In Number 50 (2 October 1729) the new publisher, Benjamin Franklin (who had converted the numbering from roman to arabic), announced that he was dropping the installments from Religious Courtship as well as the excerpts from the Cyclopaedia, noting that, taken in turn, they would require another ten years to complete. At the same time he made the first of several announcements that he planned to print Defoe's work, commenting that "those who approve of it, will doubtless be better pleas'd to have it entire, than in this broken interrupted Manner." He never fulfilled his promise.

The full title of Defoe's work is adequately descriptive of its thesis: Religious Courtship: being HISTORICAL DISCOURSES ON THE Necessity of Marrying Religions Husbands and Wives only. AS ALSO OF Husbands and Wives being of the same Opinions in Religion with one another. In the preface Defoe again discusses method or style: "Historical Dialogues ... have a very takjng Elegancy in them, and the Story being handerl forward in short Periods, and quick Returns, makes the retaining it in the Mind easier, and the Impression the more lasting, as well as delightful."

He anticipates objections to a woman's risking the loss of her lover by inquiring into his religious beliefs, saying that "no Man of any tolerable Share of Sense, will address himself to a Lady for Marriage, but he ruill take care to anticipate her Enquiries of that Kind, by shouing some Concern, for knouing what she is herself." The hook is a "Satyr" upon thosc who neglect such preliminaries to marriage, and the author cites as proof of the need for it:

The happy Life of the youngest Sister, who came into the Measures proposed; and the miserable Condition of the second Sister, who rashly threw herself into the Arms of a Man of differing Principles from her own, tho' blest with all the goot Humour in the World.

Defoe reminds readers that "if the Women seem to be favoured" in the outcome, "it is because really the Hazard is chiefly on their Side, and they are generally the greatest Sufferers in the Success; but if it were otherwise, yet, if they are treated with more than ordinary Regard, the Author hopes they will not lay that $\operatorname{Sin}$ to his Charge."28

Religious Courtship was apparently very close to Moll Flanders in date of composition; it was published only three weeks later, and by the same bookseller, Brotherton, who published the second edition of the novel. ${ }^{34}$ The short 
dialogues into which it is divided involve the principal characters, the father, his three daughters, and husbands prospective and actual, in scenes many of which seem to anticipate Richardson's Clariss. They were perfect for serializing in the Universal Instructor.

There is no questioning the sympathy for women that Defoe first displaycd in An Essay on Projects; but here it lends life to the story and helps one understand why Franklin did not attack Keimer for printing installments of the work in his otherwise inept newspaper. Straitlaced as the youngest sister is, she is gifted by Defoe with a sense of irony and an occasional forthrightness, qualities also displayed by Silence Dogood. Franklin's sympathy for the plight of women was first shown in the Dogood letters, and with such an immediacy that it seems likely he had read Defoe only shortly before the made use of the two excerpts from the Essay in Letters No. 5 and No. $10 .^{25}$ In No. 5 , Mrs. Dogood responded to a letter from "Ephraim Censorious" commanding her to criticize the faults of her own sex-idleness, ignotance, folly, and especially female pride-before attempting to reform men. After noting that men and women both have their share of the same vices, Mrs. Dogood quotes from Defoe's proposal of an academy for women in which he had asked ". . . what has the Woman done to forfeit the Privilege of being taught?"20 Franklin recalled in his memoirs the disputations he had had with one John Collins, a boy of his age, during his apprenticeship: "A Question was once some how or other started between Collins and ine, of the Propriety of educating the Female Sex in Learning, and their Abilities for Study. He was of Opinion that it was improper, and that they were naturally unequal to it. I took the contrary Side, perhaps a little for Dispute sake. ${ }^{32 \pi}$

Contrary to popular opinion, there was nothing unusual about Defoe's recognition of women's suffering for lack of education. The Athentian Gazetie, or Castuistical Mercury (1691-1697), a semi-weekly periodical which sought to answer all kinds of questions from its readers, and with which Defoe had some connection, took up the matter frequently. A reader who believed it impossible that the "natural impertinencies" of women "shou'd ever be converted inta a solid Reasoning," asked "Whether it be possible for a Woman that will be Industrious in the Pursuit, to make any considerable progress in Learning?" The answer might wel] have been written by Defoe: Men have tyrannized over women throughout history; they have kept the best things to themselves; and they have unjustly deprived woman of "the greatest of all Goods; to wit, that of the Mind, whose fairest Ornament is Knowledge, the chief good both of this World and the next, and the Noblest Action of the Souls most excellent Faculty, Understanding, which is common to Women as well as to Men, over 
engaging than anything I ever heard. Let his Biographer finish his character. He is 82 years old, and possesses an activity of mind equal to a youth of 25 years of age."

Although Franklin lacked the journalistic versatility of a Defoe, he was more than equal to the daily and weekly demands for newspaper copy during the years he was actively engaged in publishing the Pennsylvania Gazette, the newspaper he took over from the unfortunate Keimer. Poor Richard's Almanac was a triumph of synthesis and transformation, exhibiting Franklin's gift for turning dross into gold. Had he been as dependent as Defoe upon writing for a living, he might have turned out more upon a larger plan.

In 1725, when Franklin was in London and working for the well-known printer James Watts, a large work of Defoe's was in press there, the Complete English Tradesman. ${ }^{\text {as }}$ The work had a complex printing history of expansions, title change (from Complete to Compleat), and of ill-advised revisions, the last made after Defoe's death in 1731. It was one of the works to be found in the subscription library started by Franklin in $1732^{86}$ Defoe wrote it especially for young beginners and in the form of familiar letters. From his own experience he had come to believe that the world greatly wanted such a book:

... be it that those unfortunate creatures that have .. blown themselves up in trade have miscarried for want of knowing, or for want of practising what is here offered for their Direction, whether for want of wit, or by too much wit, the thing is the same, and the direction is equally needful to both. ${ }^{37}$

Along with all sorts of inside information, much of it unmistakably drawn from the author's experience in trade, to help the beginner avoid being cheated, there is a letter on the tradesman's writing of letters. In these pages Defoe cnioys himself thoroughly while imparting useful information to the reader:

As plainness and a free unconstrain'd way of speaking is the beauty and excellence of speech, so an easie free concise way of writing is the best stile for a tradesman. He that affects a rumbling and bombast stile, and fills his letters with long harangues, compliments, and flourishes, should turn poet instead of tradesman, and set up for a wit, not a shopkeeper. Hark how such a young tradesman writes out of the country to his wholesale man at London upon his first setting up.

"Sir, The destinies having so appointed it, and my dark stars concurring, that $\mathrm{I}$, who by nature was fram'd for better things, should be 
whom too they seem to have the Advantage of Wit ... we have Examples of such as have excelled in Divinity, Physick, Politicks, Philosophy, Poctry, and in Eloquence ... And as for other Sciences, if Women joined together with Men in the discovery of them, no doubt, but their Curiosity wou'd slarpen mens Wits, who are disturb'd by extraneous Aftairs, and by their help they might make great Progresses, and find out many rare Secrets, hitherto unknown."2s

The passages from Defoe's Essay quoted by Franklin in the Dogood letters resemble the polemical style of the Athenian Mercury rather morc than they do the later "historical dialogues" of Defoe. Neither the one about the academy nor that about pensions for widows demonstrates the mixture of narration and dialogue that Franklin found so admirable in Defoe and others. (There is a remarkably fine example in the Essay, however, a conversation between two inmates of a sponging house, one of them being an old hand at the business and the other new and inexperienced at dodging his creditors.) ${ }^{20}$ Franklin's judgment of Defoe's style was set down late in his life; when he was sixteen he took from An Essay on Projects what would serve his purpose in writing for the New-England Courant.

On the whole, Defoe's Essay offers far less insight into human behavior than is found in his conduct manutals. The younger Defoe of the Essay, in his late thirtics, was almost exclusively involved in business ventures, even though he had done a fair amount of writing. He published Religiour Courtship when he was almost sixty. But in the Essay there is much in addition to the two projccts so appropriately quoted by Silence Dogood that must also have inpressed Franklin; and had Defoe been able to know the mature Franklin of mid-eighteenth century, he would surely have thought him amenable to the "projecting Humour." Indeed, Franklin's entirc carcer is outlined by projects -in business, in public enterprises, and in the laboratory, to say nothing of those figuring in the formation of a new nation. He was an honest projector, as Defoe defined one in the introduction to the Essay. Having side-stepped a digression on "a Patent-Monger, whose Cully was no body but my sclf," Defoe continued:

But this is no reason why Invention upon honest foundations, and to fair purposes, shou'd not be eneourag'd; no, nor why the Author of any such fair Contrivances should not reap the harvest of his own Ingenuity; our Acts of Parliament for granting Patents to first Inventors for Fourteen years, is a sufficient acknowledgment of the due regard which ought to be had to such as find out any thing which may be of publick 
Advantage; new Discoveries in Trade, in Arts and Mysteries, of Manufacturing Goods, or Improvement of Land, are without question of as great benefit, as any Discoveries made in the Works of Nature by all the Academies and Royal Societies in the world."

Defoe's notions of "doing good" were reflected in Franklin's career. His project for improving all the main roads of England is paralleled by Franklin's proposal for paving and cleaning the strects of Philadelphia; ${ }^{31}$ both were fascinated by the possibilities in plans for insurance and pensions; Franklin excelled when it came to ingenious ways of providing comfort or convenience, as with the Franklin stave, but both approached any problem with "What if?," exhibiting a new kind of pragmatism in a century that to both of them seemed to have unprecedented possibilities. Locke's polemic against innate ideas really made way for the friendly societies and juntos of the eighteenth century. Defoe and Franklin, in their own ways, exemplify the change. It is significant that $A n$ Essay on Projects was dedicated to Queen Reason.

Swift, in the Examiner, objected to the "mock Authoritative Manner" of the author of the Review, whom he thought an illiterate scribbler. ${ }^{32}$ But there was no one the equal of Defoe, especially in his later work, in writing authoritatively and informatively on a subject, of teaching a lesson and yet keeping the style lively, studding the work with illustrative anecdotes in which seemingly real people work out tcal problems. As the envoi to the Essay on Projects, Defoe wrote:

As to Language, I have been rather careful to make it speak English suitable to the Manner of the Story, than to dress it up with Exactness of Stile; chusing rather to have it Free and Familiar, according to the Nature of Essayss, than to strain at a Perfection of Language, which I rather wish for, than pretend to be Master of. ${ }^{\text {a }}$

Here "Story" is more important to the sense than "the Nature of Essays"; with the exception of those pamphlets in which. Defoe answered an opponent point for point, the story was always uppermost in his mind. Franklin too put stories to infinite uses. After the Constitutional Convention, an admiring colleague, Maijor William Pierce of Georgia, wrote the following character of Franklin:

Dr Franklin is well known to be the greatest phylosopher of the present age; . . But what claim he has to the politician posterity must determine. It is certain that he does not shine much in public Council,- -he is no Speaker, nor does he seem to let politics engage his attention. He is, however, a most extraordinary Man, and tells a story in a style more 
put out to a trade, and the gods laving been so propitious to me in the time of my servitude..."

And so on.

Franklin, in answer to a query proposed to the Junto, wrote a discussion of literary style that was printed in the Pennsyluania Gazette, 2 August 1733 . His principles of style were much like Defoe's: "To write alearly, not only the most expressive, but the plainest Words should be chosen . . . The fondness of some Writers for such Words as carry with them an Air of Learning, renders thern unintelligible to more than half their Countrymen."30

There seems no way of knowing whether Franklin and Defoe ever met, although they might well have passed each other in Watt's printing shop-the "Water American," who persuaded his fellow printers to stop fuddling their senses and pieing their type with ale, and the strange, surprising author of Robinson Crusoe, Moll Flanders, and the Compleat English Tradesman. The American was to return to Philadelphia and a brilliant career marked by constant inquiry into the reasons for things. Defoe, in the six years of life remaining to hitn, was to publish almost half a hundred more works, ranging from A Brief Case for the Distilleries (1726) to An Essay on the History and Reality of Apparitions (1727), as wcll as onc more conduct manual, Conjugal Letudness: Or, Matrimonial Whoredom (1727), another plea for women's rights, which Franklin seems never to have mentioned reading. Defoe still puzzles us more than Franklin, but in studying his influence upon his American admirer we may come to a better understanding of both.

\section{Notes}

1. The Papers of Benjamin Franklin (New Haven: Yale University Press, 1959), I, 8-45; hercafter referred to as Papers, I. 1966.

2. Edited with an introduction by David Levin (Cambridge, Mass.: Bellenap Press),

3. Banifacius, p. 13.

4. Bonifacitss, $\mathrm{pp}, 22-23$.

5. Bonifaciss, p. 32 .

6. The Amobiography of Betrimin Fitnklin, ed, Labrce, Kctaham, Boatfield, and Fineman (New Haven; Yale University Press, 1964), pp. 148-60; hereafter referted to as Autobiography.

7. Papers, I, 10.

8. Papers, $\mathrm{I}, 10$.

9. Papers, 1, 11.

10. Papers, I, 13.

11. Antabiography, p. 67; for a thorough study of the isstes dealt with, see George F. Horner, "Fratrklin's Dogood Papers Re-exnmined," SP. 37 (1940), 501-23.

12. Professors ]. A. Leo Lemay and Paul M. Zall are preparing for pubtication a genetic text. I am indelated to them for this data. 
13. Autobiography, pp. $57-58$.

14. The Writings of Benjamin Franklin, ed. Albert Henry Smyth (New York: Maemillan, 1906), IX, 208.

15. Diary of Cotton Mather 1709-1724 (2 vols.) (Boston: Massachwsetts Historital Society, 1912), 11, 74.

16. Autobiography. p. 72. Franklin sold the Family Instractor in his lrokshop in 1740; he reprinted Pamela: or Virtue Revyarded (1740) from its fourth London edition in 1742 and 1743, malking it the first novel reprinted in Americat.

17. Family Instructor, 15th ed., 2 vols. (London: C. Hitch, L. Hawes, G. Keitb, W. Johnston, T. Longman, 1761), I, vi.

18. Fanily Instructor, $\mathrm{I}, 9$.

19. Fanily Instructor, I, 10-11.

20. John Rohert Moore, A Checklist of she Writings of Daniel Defoe, 2nd ed. (Hamden, Conn.: Archon Books, 1971), p. 181.

21. Pemsyluania Gazette (1728-1789) (Pbiladelphia: Microsurance, 1968), Vol. 1 (1728-1731), No.V (21 November 1728).

22. Papers, I, 111-39.

23. Religions Courtship (London: E. Matthews, A. Bettesworth, J. Brotherton, W. Meadows, 1722), "Preface," n.p.

24. Moote, Checklist, pp. 180-82.

25. Papers, $1,18-21,32-36$.

26. Essay on Projects (London: Tho. Cockeril, 1697), p. 284.

27. Aulobiography, p. 60.

28. Vol. 12, No. 4 (4 November 1693 ).

29. Essay on Projects, pp. 199-202,

30. Essay on Projects, pp. 14-15.

31. Autobiography, pp. 201-3.

32. Prose Works, ed. Herbert Davis (Oxford: Blackwell, 1940), 1II, 14.

33. Essay on Projects, p. 336.

34. "Notes of Majoz Willian Pierce ...," in Documents tllustrative of the Formation of the Union of the American Stales (Washington: Government Printing Ofice, 1927), p. 100 .

35. Moore, Checklist, Fp. 19899.

36. Pennsyluenia Matgazine of History and Bingraphy, 30 (1906), 301.

37. Complete English Traderman (London: Rivington, 1726 [for 1725]), I, iv.

38. Complete English Tradesmen, I, 23.

39. Papers, $\mathrm{I}, 329$.

40. Moore, Checklist, pp. 207-8. A facsimile reprnduction with an introduction by Maximillian E. Novak was published in 1967 by Scholats' Facsimilies \& Repriats, Gaincsville, Florida. 


\section{Man and Yahoo:}

\section{Dialectic and Symbolism in Gulliver's "Voyage to the Country of the Houyhnhnms"}

By JAMES E. Gih.

The relationship of European man to the Yahoos and Houyhnlinmons in Part IV of Gulliver's Travels has either puzzled Swift's readers or has been the subject of disagreement among them. ${ }^{1}$ Some of the earliest readers of the Travels, for example, were convinced that the Yahoos represent man as he "is naturally constituted" or that they represent "fallen man." Others have theorized that the Yahoos and Houyhnhnms respectively represent the human traits of passion and reason or that "man is placed ... somewhere between the rational Houyhnhnns and the bestial Yahoos. He has less reason than the former, more than the latter." Another group of readers has seen in the Houyhnhnms a representation of enlightened man as the Stoics or deists might have depicted him, and others have seen in the Yahoos "Christian symbols of sin." Although in most of these interpretations it is assumed that Yahoo and Houyhnhnm are symbolic or allegorical figures, some recent studies of Part IV have suggested that its argument is "worked out not allegorically at all but by means of a marvellous fable." According to this view Part IV is neither elaborately allegorical nor symbolic but "mythical."

Many of these studies are at best confusing because of their insistence on fixing oversimplified significances to the chief figures of the voyage: it seems that the allegory must be a matter of rather simple equivalencies or that it must not exist at all. Both of these positions are, I believe, inadequate and restlt from taking the narrative of Part IV too much for granted. The meanings attached to the Yahoo and to civilized man, for example, are not at all to be winnowed to an easily managed simplicity but are instead developed into an almost imponderable complexity. This complex development, which is the object of this study, I wish to explore in some detail throughout the first eight chapters of Part IV; for to understand the chief functions of Yahoos in the narrative is surely a proper step toward comprehending the more vexing problem of the Houyhnhnms' significance.

One important feature of the fourth voyage which many critics have failed to analyze is that the broad structure of Part IV includes a complex dialectic. The dialectic arises from the basic narrative situation-the confrontation of two fundamentally different worlds or points of view: the real but artificial 
world of Europe represented by Gulliver confronts the mythical but "natural" world of the Houyhnhnms." Since each of these wotlds is initially unintelligible to the representative or agent of the other, the narrative is shaped by the attempts of Gulliver and the Master Houylunhm to comprehend cach other's world. Because the "facts," the concepts, and the languages of the two worlds differ radically, Gulliver and his Master must engage in a process of definition and redefinition so that each can understand the other. The resultant dialectic remains imperfect, however, not only because "our barbarous English" possesses terms which are virtually untranslatable into the tongue of the horses but also because one society's application of "common" terms is either the inverse of, or at least radically different from, the other's usage. As a result, there are shifts from the terminology and norms appropriate in one world to the corresponding but connotatively different terminology and norms appropriate in the other world.

These shifts overlay and confuse the dominant narrative process of the first eight chapters of Part IV-a process leading to the "conclusive" identification of Gulliver as a Yahoo. Thus what might seen to be a simple, straightforward, and devastating equaling of man with the Yahoo is in reality complicated and qualified by several stubsidiary processes. The broadest complication is the theriophilic judgment that civilized man is worse than the Yahoo of Houyhnhnmland. ' The ambiguities thus created are anticipated and corroborated by the symbolic processes of these chapters; for the symbolism intrudes yet other standards of comparison which justify neither the simple identification of civilized man with the Yahoo nor the judgment of him as worse than the Yahoo. These ambiguities are in turn supported by the dialectical problems which arise when Gulliver, as he describes Europe to his Master, is forced to accommodate alien terms and concepts to his Master's, and for that matter to the reader's, understanding. And this complex process leads to the reader's awareness of the problems in narrative point of view in the Travels-problems which provide yet another qualifying perspective on the action of Part IV. When, therefore, Gulliver in the middle of Chapter VIII can "no longer deny, that I was a real Yahoo," the identification of civilized man with the bestial Yahoos occurs at the expense of several complex distinctions, some of which favor Gulliver and some of which, paradoxically, do not.

\section{$T$}

When Gulliver first discovers Houylnntumland, it is quite obvious that he is, despite his many marvelous experiences, quite unprepared for the radical reversal of the roles of man and beast which he encounters there. His first 
contact with the Yahoos results, to be sure, in his conceiving a violent antipathy for them, but it does not result in any recognition of their "humanity." On the contrary, what Gulliver discerns in the Yahoos is theit alternate aggressiveness and cowardliness, their bestial appearance, and their filthiness. And when he first meets the Houyhnhnms, he is "amazed to see such Actions and Behaviour in Brute Beasts," and concludes "that if the Inhabitants of this Country were endued with a proportionable Degree of Reason, they must needs be the wisest People upon Earth" (p. 209). Thereafter he concludes, "they must needs be Magicians" (p. 210), and he candidly addresses them as such.

In the light of succecding devclopments Gulliver's initial confrontation of both Yahoo and Houyhnhnm is intensely ironic. Although Gulliver is in search of natives, he does not recognize his own kind in the figure of the Yahoos. Nor is he, quite naturally, prepared to enter a land where "a Houghnham should be the presiding Creature of a Nation, and a Yahoo the Brute" (p. 223). Because of the horses" rational behavior, Gulliver is prepared to find the human inhabitants of this strange land "the wisest Peoplc upon Earth." Yet in spite of this expectation, Gulliver proposes to treat these wise "men" like natives when he is conducted to the Master Houyhnhnm's stable: "I waited in the second Room, and got ready my Presents, for the Master and Mistress of the House: They were two Knives, three Bracelets of false Pearl, a small Looking Glass and a Bead Nccklace" (p. 212). But instead of encountering a human being, "a Man of Quality" who is incredibly "served all by Horses," Gulliver is led into the dwelling only to confront a mare who "after having nicely observed my Hands and Face, gave me a most contemptuous Look ..." (p. 213). The comedy of the scene is vaguely reminiscent of that of a hunter who has captured some weird animal and brings it home to show his wife, who, after examining it, cringes in horror; but the serious effect of the scene is to represent Gulliver as a creature totally alien to Houylhhnm society at the same time that the possibiitity of the existence of such a society is beginning to take shape in his mind.

The discovery that Houyhnhnm society is self-containcd and non-human is quickly followed by the initial, tentative identification of man with Yahoo. The first hint comes after the first impressions of the Master Houyhnhntr and the Sorrel Nag are confirmed by the Lady Houyhnhnm, all of whom describe Gulliver as a Yahoo ("I heard the Word Yahoo often repeated betwixt them" [p. 213]), after which Gulliver is led out and compared with one of the Yahoos in their kennel.

The process of identifying Gulliver with the Yahoos is delayed, however, by the Houyhnhnms' puzzlement aver his clothes. During Gulliver's first en- 
counter with the horses, it will be recalled, they appear to be nonplussed by Guiliver's appearance, especially by the softness of his skin and by his garments (pp. 209-210). And after Gulliver discerns in the Yahoo "a perfect human form," he continues the mystification of the Houhynhnms by deliberately concealing the secret of his clothes. As a kind of screen his clothes signal Gulliver's duplicity and a comic craftiness; and as a means of distinguishing himself from the Yahoos they signal Gulliver's pride and man's pretentiousness. Gulliver, of course, wishes to hide those physical attributes which he himself finds so odious in the Yahoos-qualities which he will discover in all mankind during his stay in Houylnhnmland. As they are developed, these traits, the Yahoo's hirste filthiness and deformity, becomc the external signs of that brute's vices-his love of dirt, his gluttony, his lasciviousness, his avaricc, his simultaneous rapaciousness and cowardice, and consequently his alienation from the "Nature" which beneficently regulates the affairs of all other brutes.

But Gulliver's wearing of clothes also manifests another trait of the civilized man, for hiding one's body is a tacit admission of the principle of shame and guilt, a sign of an awareness of the corrupt nature of man. Gulliver alludes to this principle when he accedes to his Master's request for enlightenment, "only desiring his Excuse, if I did not expose those Parts that Nature taught us to conceal" (p. 220). And he shows an awareness of the multiple function of clothes when he describes them as "the Hairs of certain Animals prepared by Art, as well as for Decency, as to avoid the Inclemencies of Air both hot and cold" (p. 220).

To the Master Houyhnhnm Gulliver's modesty is unintelligible, "for he could not understand why Nature slould teach us to conceal what Nature had given. That neither himself nor Family were ashamed of any Parts of their Bodies" (p. 221). Here the term "Nature" is used by Gulliver with normative force, a usage which the Master Houyhnhnm ecrtainly comprehends since the entire rationale of Houyhnhnm life is a kind of life according to Nature. The effect of the Master Houyhnhnm's response is to raise a question about the real function of clothing and about the "Nature" to which Gulliver alludes. "The "Nature" associated with Gulliver's clothes is, in the "natural" world of the fourth voyage, a human attribute peculiar to neither Houyhnlinm nor Yahoo. It is in Fact a "Nature" cotnmon to civilized humanity and to no other kind of creature. The opposition of these two concepts of "Nature" within the dialectical framework of the fourth voyage thus raises a question about the place of "human nature" within the framework of a larger, more inclusive concept of "Nature."

A confrontation of the world of humanity with the natural world of the 
Houyhnhnms much more direct and explicit than that which is implicit in the clothes symbolism interrupts the devclopment of that symbolism and eventually redirects it; for after only tentatively identifying Gulliver as a Yahoo, the Master Houylunhnm is "more astonished at my Capacity for Specch and Reason, than at the Figure of my Body" and is therefore bent on Gulliver's improvement in the Houyhnhnm tongue, for "he waited with some Impatience to hear the Wonders which I promised to tell him" (pp. 221-22).

The passuges which follow include Gulliver's first lengthy "conversation" with his Master in which he attempts to describe his own native land. Again, a misunderstanding occurs early in the narration when the Master Houyhnhnm is unable to comprehend how English Houphnhnms could construct a ship and why they should entrust such a vessel, presuming that it could be built, to their Yahoos. Again Gulliver is forced to state the facts of his own world as he knows thern: he painstakingly explains

that the Ship was made by Creatures like myself, who in all the Countries I had travelled, as well as in my own, were the only governing, rational Animals; and that upon my Arrival hither, I was as much astonished to sec the Howy/hnhms act like rational Beings, as he or his Friends could be in finding some Marks of Reason in a Creature he was pleased to call a Yahoo; to which I owned my Resemblance in every Part, but could not account for their degenerate and brutal Nature. I said farther, That if good Fortune ever restored me to my native Country, to relate my Travels hither, as I resolved to do; every Body would believe that 1 said the Thing which was not; that I invented the Story out of my own Head: And with all possible Respect to Himself, his Family, and Friends, and under his Promise of not being offended, our Countrymen would hardly think it probable, that a Houyhhmm should be the presiding Creature of a Nation, and a Yahoo the Brute. (pp. 222-23)

From this point on, the dialogue consists of a series of paradoxes-paradoxes of situations arising from the two conflicting sets of data offered by the interlocutors and paradoxes arising from the Master Houyhnhnm's interpretation of Gulliver's description; morcover, Gulliver's attempts to correct his Master's erroneous conclusions merely lead him further into more fundamental paradoxes which, from his Master's point of view at least, are inexplicable.

The first of these paradoxes arises from Gulliver's first, and incomplete, description of the treatment of "Houyhnhnms" in England. "I told him, we had great Numbers; that in Summer they grazed in the Fields, and in Winter 
were kept in Houses, with Hay and Oats, where Yahoo-Servants were employed to rub their Skins smooth, comb their Manes, pick their Fect, serve them with Food, and make their Beds" (p. 224). This pampering of liorses by those men who can afford it (itself condemued by implication) is, of course, misinterpreted by the Master Houylunhnm: "I understand you well, said my Master; it is now very plain from all you have spoken, that whatever Share of Reason the Yahoos pretend to, the Houyhnhtims are your Masters; I heartily wish our Yahoos would be so tractable" (p. 224). Thereupon, to correct his Master's mistaken impression, Gulliver is compelled to reveal man's brutality to animals and his "unnatural" means of rendering a physically more powerful fellow creature "more tame and gentle" (p. 225).

But even granting that the brutal treatment of horses by man to some extent accounts for the dominance of European man over European beast and granting temporarily that in Europe man may be the only creature partaking of reason, which "will in Time always prevail against Brutal Strength," the Master Houybnhnm is nevertheless compelled to conclude that "he thought no Creature of equal Bulk was so ill-contrived, for cmploying that Reason in the common Offices of Life" (p. 226). And thereatter he enters into a demonstration that Gulliver, who is "as well shaped as most of my Age" (and therefore the whole of humankind), is physically inferior not only to the Houyhnhnm but also to his Yaloo brethren. To be sure, Gulliver is "much more cleanly, and not altogether so deformed; but in point of real $\Lambda$ dvantage, be thought I differed for the worse" (p. 226). Then, of course, follows Swift's version of the traditional theriophilic critique of man's physical weakness, and in the process there occurs the same paradoxical treatment of man's physical nature that appeared in the clothes symbolism. ${ }^{8}$ The chief diference betwecn that treatment and this is onc of direction and emplasis, for the present handling of the problem of man's physical weakness Jeads into Gulliver's cxplanation of how man-Yahoo can possibly be the ruling creature in Europe.

Ultimately, the Master Houyhnhnm's inability to understand the dominance of Yahoos over other beasts derives from a conception of Nature which is typical of the world of the Houyhuhnms, for he cannot inagine the ruling creatures of any world could be less than physically and mentally superior to those whom they control. Thus the Houyhnhnms' obvious total fitness to govern their own world is signifed by the etymological meaning of the word "Houyhnhnm," "the Perfection of Nature." From the Master Houyhnhnm's point of view, therefore, the "facts" of the world of Europe are logically impossible if one grants that Nature "worketh all things to Perfection" (p. 237).

The Master Houyhnhnm's evaluation of the human physique also hearkens 
back, however, to that general complex of feeling and idea symbolized by Gulliver's wearing of clothes which implies man's physical weakness. Clothes, which, as we have previously seen, come to represent Gulliver's duplicity as well as decency, are also emphasized as a sign of man's physical weakness. When compared with the Yahoos, a clothes-wearing Gulliver is on the one hand less deformed and cleaner and on the other hand weaker and more vulnerable. And these meanings as well as human "art" and human concern for propriety or decency are concentrated in the figure of Gulliver's clothes. A similar ambiguity is involved in the fact that clothes are at once merely external objects, intrinsic to and inseparable from Gulliver, for although he takes them off when he sleeps and although he realizes that his present clothes will soon wear out (p. 220), he never for a moment dreams of dispensing with clothes in general: his clothes are a sign of his nature, and of his intuitive awareness of his nature, although that awareness is not at present, at least, fully developed and although he does not appear to comprehend fully at any one time the ambivalent implications of clothing as symbolic."

The concentration of these contrasting themes and meanings in the figure of Gulliver's clothes thus poses a serious interpretive problem since the whole question of civilized man's nature seetns by implication bound up in the Houyhnhnms' puzzlement about them. Do Gulliver's clothes come to symbolize man's attempt to "cover" his unregenerate nature, or do they symbolize his attempt to meliorate and correct his natural flaws? To state the question more clearly, to what degree is man's moral nature real and to what degree is it simply an illusion ? ?tI $^{\text {t1 }}$

The paradoxical way in which this question is asked depends, of course, on the tentative identification of Gulliver as a Yahoo and on interplay between the physical attributes of the Yahoos and the mental and moral qualities which their physical "deformities" come to represent, i.e., on an interplay between concrete "fact" and the metaphoric or symbolic significance of such concretions. The Yahoo's "deformity," for example, cannot truly be considered as a departure from some normal or typical or idealized concept of the human figure, except perhaps by Gulliver, who has some general notions of the "perfect" human form. But the Master Houylnhnm can have no such norm in mind since he has never seen another civilized human being. One may ask if the term "deformity" has not in fact been introduced chielly for its metaphorical significance just as other terms such as "filthincss" and "ugliness" have been introduced for the same reason, although in the case of the latter terms, the Master Houyhnhnm does indeed possess knowledge which constitutes a basis of comparison. "Deformity" here posits a norm which the reader readily com- 
prehends since he shares with Gulliver knowledge required for the comparison, and on the basis of that knowledge he can judge the Yahoos to be physically "abnormal." The Yahoo's physical "deformity" is, however, obviously connected with that brute's mental deformity, and the two taken together render each other intelligible in terms of the concrete world of the fourth yoyage and in terms of the symbolic and allegorical significance of that world.

The paradox that Gulliver is physically superior to the Yahoos (i.e., cleaner and less deformed) and at the same time physically inferior to them (i.e, weaker) thus depends in large part on a shift from one universe of discourse to another-from the tenor (the symbolic meaning) to the vehicle (the image conveying the symbolic meaning), or from the symbolic significance of the concrete fact to the literal import of the concrete fact. ${ }^{11}$

This paradoxical development of the literal implications of a symbol so that as symbol it becomes ambiguous differs very little from the same technique employed by Swift in Gulliver's first two voyages. In each of these, contrast between big and littie, as has long been understood, gives rise to conflicting valuations of relative size. Thus in Lilliput smallness symbolizes a variety of insidious pettiness and overblown pride as well as neatness, orderliness, and fastidiousness. In contrast, Gulliver the ingenu is honest and trusting as well as gross and somewhat insensitive. In the second voyage, of course, this scheme is reversed: the reeking giants of Brobdingnag are in general magnanimous and good-humorecl as wetl as insensitive and grossly mortal whereas Gulliver as homunculus becomes pretentiously tender of his own honor and importance. ${ }^{12}$

Thus the general effect of the symbolism is to render man's advantages as disadvantages and vice versa, but because the meaning of the symbolism is best seen as anticipating the later explicit question about the moral (or rational) nature of man, it does not necessarily embody an answer to the question which it raises. Gulliver's puzzled and defensive posture at the conclusion of his Master's logical objections to the fact of man's dominance throughout the greater part of the world still does not at this point in the voyage preclude the possibility of reason and morality among human beings, for there are three possible answers to the question thus posed-_- "yes," "no," and "yes and no." In other words, one can conelude from the symbolic treatment of Gulliver's clothes in connection with the more explicit criticism of the human figure by his Master that in some respects man's supremacy in most parts of the globe is either totally illusory or quite real; or one can conclude that, as in the previous symbolism in the Travels, these antithetical propositions are a part of a dialectical movement in which neither is predominant, but in which cach qualifies the other so that one can only conclude that in some respects man 
resembles the Yahoo and in others he differs. To be surc, man differs "for the worse" in some instances, but in others he surely seenss superior. It is, however, virtually impossible to pin down the meaning or valuation of man's "inferior" and "superior" aspects at this poinc in the voyage becausc of the more or less constantly shifting contexts in which they appear and are discussed-shifts from a "real" to a theoretical or hypothetical world and shifts from symbolic to concrete contexts. What can be ascertained is that the symbolism, in concurrence with the more explicit development of the narrative, complicates what appears to be a straightforward criticism of man and at the same time both corroborates and sets up a countercurrent against that movement which results in the complcte condemnation of man as not only worse than ordinary beasts but also worse than his degenerate brethren, the Yahoos.

The ambiguity of the clothes symbolism and the corresponding discussion of man's physical nature are highlighted and, as it were, confirmed by the fact that the Master Houylinhnm and Gulliver leave the issue unresolved so that Gulliver can improve his knowledge of the Houylnhhnun tongue. The Master Houyhnlinm is, after all, "more astonished at my Capacity for Speech and Reason, than at the Figure of my Body," and desires Gulliver to learn the language so that he may "hear the Wonders which I promised to tell him" (pp. 221-22), wonders which merely complicate the process of comic misunderstanding and embarrassing clarification begun by the initial confrontation of Guiliver and the horses. The emphasis on speech and reason here, asicle from providing a primary narrative impulse toward Gulliver's later discussions with his Master, also prefigures the major "philosophical" issucs which will arise from those conversations, for the overall controlling narrative process consists of the "redefinition" of man in terms of his relation to the Yahoo.

\section{II}

The process of identifying man with Yahoo and at the same time differentiating between man and Yalıoo continues, therefore, throughout Gulliver's description of European custorns, an exposition which occupies the central portion of the fourth voyage and which follows hard upon the discovery of the physical resemblance of Yahoo and man, as well as the differences bewween them. Here the process is carried on in part under color of the linguistic diffculties under which Gulliver labors in trying to inform his Master. This diffculty is hinted at several times; for example, when Gulliver explains why his crew had mutinied, he is required to use terms of which his Master has no comprehension: 
To clear up which I endeavoured to give him some Ideas of the Desire of Power and Riches; of the terrible Effects of Lust, Intemperance, Malice, and Envy. All this I was forced to define and describe by putting of Cases, and making Suppositions. After which, like one whose Imagination was struck with something never seen or heard of before, he would lift up his Eyes with Amazement and Indignation. Power, Government, War, Law, Punishment, and a Thousand other Things had no Terms, wherein that Language could express them; which made the Difficulty almost insuperable to give my Master any Conception of what I meant. ...

(p. 228)

Now of course the term in the Houyhnhnm tongue which signifies "man" is "Yahoo," a fact acknowledged by Gulliver earlier when he endeavors to explain that in Europe men are the ruling race: "And with all possible Respect to Himself, his Family, and Friends, and under his Promise of not being offended, our Countrymen would hardly think it probable, that a Houyhnhmm should be the presiding Creature of a Nation, and a Yahoo the Brute" (p. 223). This passage, it should be recalled, occurs long beforc Gulliver has seen any detailed proof of the moral kinship of man and Yahoo.

Gulliver does not, however, inevitably employ the word "Yahoo" to mean "man." The fact that the mode of discourse employed in the fourth voyage, as throughout the Travels, ${ }^{13}$ is indirect discourse allows Gulliver as narrator to interchange terms to convey an impression of his difficulties in communicating with an alien race as well as to interchange foreign and native terms in order to accommodate these alien terms to the English rcader's understanding. A kind of consistency of point of view is thus established. Equally important, use of this device also provides Swift with the means of directing and pointing the satire and of effecting the association of man and Yahoo as well as of leaving open the possibility of a differentiation between them. ${ }^{1.1}$

Swift's complicated procedure here can best be iliustrated by examining the language of Chapters IV-VI (Pp. 224-41), the chapters which include the devastating exposé of European society and which immediately precede the Master Houylnhnm's analysis of the parity between Yahoo and civilized man (Chapter VII). One of the most notable aspects of this procedure is the fact that Gulliver sometimes uses expressions such as "man," "mankind," "fellows," and "people" by themselves, without associating them with Yahoos, whereas in other instances he is quite forthright in branding a European with the appellation of "Yahoo." And at yet other times he uses "man" and related terms in conjunction with terms borrowed from the language of animal husbandryterms such as "female," "male," and "animal." 
When "man" and related terms are found by themselves, they are usually employed in contexts in which men are seen as victims of other men. Thus when the Master Houyhnhnin notes of lawyers that "it was a Pity, that Creatures endowed with such prodigious Abilities of Mind as these Lawyers, by the Description I gave of them must certainly be, were not rather encouraged to be Instructors of others in Wisdom and Knowledge," Gulliver is forced to reply that "they were usually the most ignorant and stupid Generation among us, ... and equally disposed to pervert the general Reason of Mankind, in every other Subject of Discourse, as in that of their own Profession" (p. 234). Similarly, lawyers are described as taking "special Care to record all the Decisions formerly made against common Justice and the general Reason of Mankind" (p. 233). Here, of course, "Mankind" is not used in a pejorative sense. These remarks, it will be recalled, are included in Gulliver's explanation of "how it should come to pass, that the Law which was intended for every Man's Preservation, should be any Man's Ruin" (p. 232). The same tendency can be seen in Gulliver's description of war. Thus, "If a Prince send Forces into a Nation, where the People are poor and ignorant, he may lawfully put half of them to Death, and makes Slaves of the rest, in order to civilize and reduce them from their barbarous Way of Living" (p. 230). And in describing Europe's economic inequities, Gulliver notes "That the Bulk of our People was forced to live miserably, by labouring every Day for small Wages to make a few live plentifully" (p. 235). And when depicting the activities and mannerisms of a Prime Minister, Gulliver observes that "The worst Mark you can receive is a Promise, especially when it is confirmed with an Oath; after which every wise Man retires, and gives over all Hopes" (p. 239). In each of these cases the non-pejorative epithet is applied to a victim.

These distinctions are, however, to be observed only within the confines of narrowly limited contexts, and these contexts are but parts of larger contexts in which certain types of men are forthrightly branded Yahoos. In the description of war, for example, Gulliver observes "that about a Million of Yahoos might have been killed in the whole Progress of" the war of the Spanish Suecession (p. 229), and later that a "Soldier is a Yahoo hired to kill in cold Blood as many of his own Species, who have never offended him, as possibly he can" (pp. 230-31). A description of the Prime Minister's office is initiated when the Master Houyhnhnm commands Gulliver "to inform him, what Species of Yahon I particularly meant by that Appelation" (pp. 238-39). And in describing the use of money to his Master, Gulliver explains the value of metals and notes "That when a Yahoo had got a great Store of this precious Substance, he was able to purchase whatever he had a mind to ..." (p. 235). ${ }^{16}$ 
The most extensive and pervasive of these processes is that in which man and Yahoo are associated by an intermingling of attributes and nomenclature. This process includes the two previously discussed, intermingles them, and thus in a sense "confuses" them. When, for example, Gulliver gives his Master a preliminary sketch of "what human Nature in our Parts of the World is capable to perform," he calls Qucen Anne "a Female Man" and refers to his mutinous crew first as "Yahoor" and then as "Feflows" ( $\mathrm{p}, 227$ ). Thereafter lawyers are spoken of as "engaging in a Confederacy of Injustice, merely for the Sake of injuring their Fellow-Animals" (p. 235); from this point on, "Ya/soo" and related terms appropriate to the description of beasts are the most frequently used terms to denote and describe civilized man. "I assured him, that this whole Globe of Earth must be at least three Times gone round, before one of our better Femalc Yahoos could get her Breaklast, or a Cup to put it in" (pp. 235-36). "But, in order to feed the Luxury and Intemperance of the Males, and the Vanity of the Females, we sent away the greatest Part of our necessary Things to other Countries..." (p. 236). "That, prostitute Female Yahoos acquired a certain Malady, which bred Rottenness in the Bones of those, who fell into their Embraces ..." (p. 237). Even so, among these passages there are others in which men ate termed "people," "man," and "mankind," and still others denoting various occupations, vices, and conditions appropriate to the society of Europe.

This three-part process, as we have seen, both distinguishes "man" as victim from Yahoo and stresses "Yahoo-ness" of certain types of men, and, in its final impulse, prepares for the general identification of men with Yahoos which occurs in the following chapter. The second and third aspects of this process generally support and adumbrate each other while the first estahlishes a faint but definitely perceptible counter-current to the last two but seems to subside under the pressure of the Master Houyhnhnm's comparison of man and Yahoo in Chapter VII.

At the same time, therefore, that Gufliver's language in Chapters V and VI points to distinctions which implicitly distinguish man from Yahoo in some respects but which also explain some of man's worst practices as Yaloo-like, Gulliver is also compelied to use terms which are peculjar to the world of the Houyhnhnms, terms in which there is an implicit distinction between the rational and the nonrational as mutually exclusive categories into which all created beings are to be logically divided. In others words, the conceptual framework of the Houyhuhnms demands the categorization of "man" as a strictly rational or a nonrational being. ${ }^{1 /}$ "Thus, as we have seen in examining the language of Gulliver's account of Europe, Gulliver intermingles the termi- 
nology appropriate to each of the two worlds of the fourth voyage but seems gradually to succumb to the "either-or" disjunction typical of Houyhnhnm thought, a general process which coincides with and partially accounts for Gulliver's gradual alienation from the world of "humanity."

The shifts from one universe of discourse to another and Gulliver's gravitation to that of the Houyhnhnms generally coincide with and are confirmed by the Master Houyhnhnn's initial critiquc of human reason in Chapter V; they also parallel the gradually developing picture of European civilization as a system which victimizes the innocent, perpetuates vice, and generally accelerates the process of the degeneration of man. ${ }^{17}$

The satiric animus of these chapters, which together constitute one of the most vitriolic diatribes against human vice ever written, derives much of its effectiveness from the fact that the underlying structures show that one vice inevitably begets other vices. Indeed, the mere progression of topics within an "associational" framcwork gives the impression of intensification.

Each of the vices mentioned in Chapter VI, for example, "happens" to arise because Gulliver "happens" to mention it in the course of his relation of still" other vices. Thus his "accidental" mention of money (p. 235) leads to his explanation of economic inequities and avarice (pp. 235-36); these in turn lead him into a discussion of craving rare foods and materials (pp. 236-37), and thence he progresses to disease, the pride of physicians, poison, ministers of state, and a decaying nobility (pp. 237-41). In addition, the fact that these perversions of "the general Reason of Mankind" were probably intended to have (and often still do have) a topical reference also heightens the satire. ${ }^{18}$

\section{III}

There is yet another dimension to this famous diatribe, one which both augments and, to a degree, mitigates the force of the satire. This dimension is created by the double-edged candor of the narrator. The impression which Gulliver as literary artist endeavors to create is one of straightforward factual accounts of European characteristics and customs, which occurred during many conversations with his Master but which for "Brevity sake" he has summarized for the reader. Gulliver makes this point twice, once at the beginning of Chapter V and again at the conclusion of the diatribe beginning Chapter VII. "The Reader may please to observe, that the following Extract of many Conversations I had with my Master, contains a Summary of the most material Points, which were discoursed at several times for above two Years; his Honour often desiring fuller Satisfaction as I farther improved in the Howy $/ \mathrm{hhmm}$ Tongue" (p. 229). And later he states, "I have related the Substance of several 
Conversations I had with my Master, during the greatest Part of the Time I had the Honour to be in his Service; but have indeed for Brevity sake omitted much more than is here set down" (p. 243). Thus while Gulliver the aged writer has preserved the order of topics as they arose during many conversations and although he las taken pains to preserve the very flavor of the conversations by rataining words and expressions poculiar to the Houyhnhnm tongue, the selection of material and language is also that of a man already turned misanthrope. It is, in fact, through such devices as these that Swift strives to reconcile the past progressive or imperfect point of view which seems to prodominate throughout the Travels with the past point of view, which posits an aged and misanthropic sea captain recounting and sometimes philosophizing about his previous expericnces. "In Swift's use of symbolism and his manipulation of Gulliver's language, however, should enable the reader to achieve the perspectives required to cope with both Gulliver's progressive and past aspects. Consequently, in addition to the other ambiguities arising from the association of man with Yahoo, the account by the aged, misanthropic Gulliver of the young and ingenuous Galliver who is being shown the Yahooness of man both effects the association of man with Yahoo and provides a perspective which enables the reader to criticize the absolute validity of that association. Indeed, one may say that the association of man with Yahoo occurs through the "accidental" exclusion of any of man's good traits, even though these good traits are logically implicit in the "minor" processes of Chapters V and VI as well as in much of the symbolism. ${ }^{20}$

Of course the selectivity which Gulliver as writer exercises in these chapters also derives from the views of the Master Houyhnhnm and bclongs to the world of the Houyhnhnms. This mental framework is one in which Gulliver is compelled to participate in part because of the necessity to communicate with his Master in the Houyhnhnm congue. Thus in a sense Gulliver is trapped in and by a point of view which is essentially alien and hostile to humanity; and when in the succeding chapters (Chapters VII and VIII) the Master Houyhnhnm observes "what Party there was in our Natures" and when the association of man with Yahoo is effected with great intensity, Gulliver is at last moved to admit that he is a Yahoo.

In Chapter VII the Master Houyhnhnm brings together his previous criticisms of man-man's physical inferiority and his perversion of reasonand draws what seems to be the obvious conclusion. Man and Yahoo are alike except that man's reason, instead of correcting and meliorating human deficiencies, aggravates them. 
He said, he had been very seriously considering my whole Story, as far as it related both to my self and my Country: That, he looked upon us as a Sort of Animals to whose Share, by what Accident he could not conjecture, some small Pittance of Reason had fallen, whereof we made no other Use than by its Assistance to aggravate our natural Corruptions, and to acquire new ones which Nature had not given us. That, we disarmed our selves of the few Abilities she had bestowed; had been very successful in multiplying our original Wants, and seemed to spend our whole Lives in vain Endeavours to supply them by our own Inventions. That, as to my self, it was manifest I had neither the Strength or Agility of a common Yahoo; that I walked infirmly on my hinder Feet; had found out a Concrivance to make my Claws of no Use or Defence, and to remove the Hair from my Chin, which was intended as a Shelter from the Sun and the Weather. Lastly, That I could neither run with Speed, nor climb Trees like my Brethren (as he called them) the Yahoos in this Country.

That, our Institutions of Government and Law were plainly owing to our gross Defects in Reason, and by consequence, in Virtue; because Reason alone is sufficient to govern a Rational Creature; which was therefore a Character we had no Pretence to challenge, even from the Account I had given of my own People; although he manifestly perceived, that in order to favour them, I had concealed many Particulars, and often said the Thing which was not.

He was the more confirmed in this Opinion, because he observed, that as I agreed to every Feature of my Body with other Yahoos, except where it was to my real Disadvantage in point of Strength, Speed, and Activity, the Shortness of my Claws, and some other Particulars where Nature had no Part; so, from the Representation I had given him of our Lives, our Manners, and our Actions, he found as near a Resemblance in the Disposition of our Minds.

(pp. 243-44)

Here is the chief paradox of Part IV. Civilized man in such a context is not as bad as the Yahoo; he is worse. In addition to the explicit judgment of the passage, it is clear from the construction of the last quoted paragraph not only that man has been identified as a Yahoo but also that an extension of the terms of the analogy ("I agreed in every Feature of my Body with other Yahoos, except where it was to my real Disadvantage") to the respective moral qualities of man and Yahoo ("so ... he found as near a Resemblance in the Disposition of our Minds") would paradoxically prove man ("to whose Share ... some 
small Pittance of Reason had fallen") to be in some sense mentally or morally inferior to the Yahoos even though the latter are characterized by their mindless cunning and amoral behavior. Those ambiguous differences between Yahoo and man-clothes, cleanliness, speech, and reason-are here all turned to man's disadvantage.

This full-scale and very witty reversal is followed by yet other reversals which are consistent with it. First, the process is reversed whereby the Master Houyhnhnm has attempted to understand Gulliver and his kind by seeing man's activities in terms of the Yahoo's behavior: Gulliver's account of humanity now enables the Master Houyhnhnm to understand the Yahoo. Knowledge of human vices, for example, cnables one to understand the Yahoo antipathy for his own kind.

He said, the Yahoos were known to hate one another more than they did any different Species of Animals; and the Reason usually assigned, was, the Odiousness of their own Shapes, which all could see in the rest, but not in themselves. He had therefore begun to think it not unwise in us to cover our Bodies, and by that Invention, conceal many of ous Deformities from each other, which would else be hardly supportable. But, he now found he had been mistaken; and that the Dissentions of those Brutes in his Country were owing to the same Cause with ours, as I had described them.

(p. 244)

In addition to the reversal of method, the clothes symbolism is here "wittily" avoided or side-stepped, and the values which have been indirectly attached to clothes in previous passages are at the same time evoked for the reader and ignored by the Master Houyhnhnm.

The Master Houyhnhnm's contention that Yahoo behavior is rendered intelligible by knowledge of human vice is confirmed by his succeeding description of the Yahoo's typical behavior and by Gulliver's unspoken but revealing commentary on his Master's remarks. Despite the intensity of the catalogue of Yahoo vices which follows, Gulliver's commentary reveals that their vices usually appear in less "aggravated" forms than their human counterparts. Thus when the Master Houyhnhnn describes the Yahoo's avariciousness over useless but pretty stones, he notes that "it was common when two Yahoor discovered such a Stone in a Field, and were contending which of them should be the Proprictor, a third would take the Advantage, and carsy it away from them both; which my Master would needs contend to have some resemblance with our Suits at Law ..." (p. 245). But in keeping with his Master's judg- 
ment that the Yahoo is less vicious than civilized man, Gulliver is compelted to observe to himself,

I thought it for our Credit not to undeceive him; since the Decision he mentioned was much more equitable than many Decrees among us: Because the Plaintiff and Defendant there lost nothing beside the Stone they contended for; whereas our Courts of Equity, would never have disnissed the Cause while either of them had any thing left. (p. 245)

With similar force Gulliver observes that the Yahoos are healthier than man and that their diseases, both real and imaginary, are more easily cured than are man's (pp. 246-48). The Yahoo's salaciousness also appears to be less vicious than man's, for Gulliver 'expected every Moment, that my Master would accuse the Yahoos of those unnatural Appetites in both Sexes, so common among us. But Nature it seems hath not been so expert a School mistress; and these politer Pleasures are entirely the Productions of Art and Reason, on our Side of the Globe" (p. 248). Finally, at the root of the matter is the fact that the Yahoos possess nothing similar to human "Learning, Government, Arts, Manufactures, and the like" (p. 246), a fact which ironically accounts for their superiority to man; for within the framework of Houyhnhnm thought such "refincments" are most often seen as the systematizing of perversions of reason.

\section{W}

At the same time, however, that the Yahoo is shown to be in certain ways superior to man, the Master Houyhnhnm's description of the Yahou's behavior reveals a close correspondence between their grizzly exterjors and their savage way of living. His catalogue of the Yahoo's vices vaguely resembles in method and intensity the parade of the Seven Deadly Sins in medieval literature: nearly all of the mortal sins, ${ }^{21}$ as a matter of fact, are characteristic of the Yahoo, for the Master Houyhnhnm describes wrath (p. 244), "Avarice" (pp. 244-45), gluttony (pp. 245-46), lechery (pp. 247-48), sloth (pp. 247-48), and envy (p. 248). To this array of vice are added violations of several cardinal virtuesinjustice (p. 245), intemperance (p. 246), and cowardice (pp. 245-46). In addition to these faults the Yahoo's antipathy to his own kind as well as to all other creatures (pp. 255-56) and his love of filth (p. 247) are thrown in for good measure. In short, almost every conceivable type of human evil is concentrated in the figure of the Yahoo-evil which he embodies in his hideous physical deformities and wild, virtually ungovernable behavior.

This concentration in the figure of the Yahoo of nearly every evil known to man accords with and is in fact the culmination of several processes already 
noted in the analysis of previous chapters. First, it accords with that process initiated by Gulliver's furst encounter with the Yahoos and developed in those passages in which Gulliver is physically compared with the Yahoos in his Master's kennel. It is in these passages that the parallel issues of Gulliver's physical and mental characteristics are given ambivalent values when seen as differentiating man from Yahoo. Gulliver is paradoxically seen as being physically inferior to the Yahoo at the same time that the Yahoo is depicted as the ultimate development in bestiality. Second, the depiction of the Yahoo in Chapter VII as the embediment of vice accords with the selective process previously isolated in Chapters $\mathrm{V}$ and $\mathrm{VI}$, where Gulliver implicitly distinguishes between man as viction and man as Yahoo. Thus at the same time the Master Houyhnhnm judges man to be worse than the Yahoo, the Yahoo is secn as an epitome of evil and bestiality-a nonrational creature who, because his every instinct is vicious, will inevitably cause vice to materialize whenever the opportunity for mischief arises. ${ }^{22}$

This paradoxical development conforms to the general, ambiguous development of the symbolism already noted and to the paradoxical scheme of the theriophilic argument; for the Yahoo is intelligible as symbol-the incarnation of human evil-as well as narrative fact. As symbol the Yahoo is human evil; as narrative fact of the world of the fourth voyage the Yahoo is superior to man. Thus in some way the irony of appearance-the irony arising from the fact that man appears to be superior to his bestial cousins but is not--can again be seen as operating against the force of the symbolism. ${ }^{23}$

Even though the Yahoo is simultaneously seen as superior to man and depicted as the cmbodiment of human evil, the essential similarity of the two is not forgotten, and the belief that both taken together as a species are by many degrees inferior to all other beasts is rrequently reiterated. All of these considerations, however, are evoked by Gulliver's unvoiced and comic responses to his Master's commentary on the behavior of the Yahoos, and their significance is part of a more complex structure of meaning. On the one hand, Gulliver realizes that the civilized version of some "human" vices is worse than the Yahoo's version of the same vice. Thus injustice among the Yahoos seems "much more equitable than many Decrees among us"; similarly the Yahoo's lechery is less "refined" and more "natural" than the European's. On the other hand, Gulliver balks at accepting some of his Master's statements which sink both man and Yahoo below the level of the beasts. When, for example, the Master Houyhnhnm describes the Yahoo's inevitable choice of the worst member of the pack as leader, Gulliver indignantly thinks, "I durst make no Return to this malicious Insinuation, which debased human Understanding below the 
Sagacity of a common Hound" (p. 247). And when his Master observes that the Yahoos are possessed of a "strange Disposition to Nastiness and Dirt; whercas there appcars to be a natural Love of Cleanliness in all other Animals," Gulliver is silent despite his "own Inclinations," for he petulantly notes that he could easily defend man "from the Imputation of Singularity" on this count by adducing the example of the pig, "which although it may be a sweeter Quadruped than a Yahoo, cannot I humbly conceive in Justice pretend to more Cleanliness" (p. 247). But alas! there are no pigs in Houyhnlunmland.

Gulliver's silent defenses of mankind, arising in part from his pride of kind, serve only to involve him further in the association of man and Yahoo, for if his desire is to defend civilized man from "malicious Imputations," he does so under circumstances which require him to defend the Yahoo also: he is tricked into justifying creatures which he has consistently seen as odious and deformed. Caughe up in an alien universe of discourse, Gulliver is trapped in a maze of inconsistencies and incongruities. Under these circumstances it is not surprising that Gulliver the deceiver (who would defend man's reputation) and Gulliver the ingenu (who because of his simplicity and candor is compelled to admit man's weaknesses) are united in these passages. Another side of the comic effect of these chapters is the incompetence of the Yahoo's version of human sins. In a way many of their antics are grotesque parodies of human impulses. The comedy of these descriptions is similar to that of the antics of totally incompetent criminals.

Despite the processes in which ir is possible to distinguish in a very complex way between man and Yahoo, between man and the Yahoo in man, and between Yahoo as symbol and Yahoo as narrative fact, the primary narrative impulse at the beginning of Chapter VIII still moves toward the final and conclusive identification of man with Yahoo. His offended pride and his fears notwithstanding, Gulliver secures his Master's permission to make sorties among the Yahoos in order to make "further Discoveries from my own Observation" (p. 249). He gives the reason in a highly ironic passage-ironic in that it sharply contrasts with Gulliver's earlicr ingenuousness and duplicity as well as ironic in the sense that his "discoveries" will later serve only to increase his mortification over his own "Yahoo-ness": "As I ought to have understood human Nature much better than I supposed it possible for my Master to do, so it was easy to apply the Character he gave of the Yahoos to myself and my Countrymen" (p. 249).

What Gulliver learns of the Yahoos in his investigations now merely confirms what he has previously heard from his Master and reinforces the irony of appearances noted previously. His attempt to capture a young Yahoo dra- 
matizes once more the Yahoo's antipathy for its own kind as well as its physical filthiness and superior agility (pp. 249-50). The Yahoos are strong and able to find their own food, consisting of roots, a variery of wild rats, and fish (p. 250); but being at the same time of a cowardly temperament, they are "by Consequence insolent, abject, and cruel" (p. 250). Doubtless many of these traits are but open and unconcealed manifestations of deviously hidden human traits, the chief exception being that the Yahoo is self-sufficicnt whereas many Europeans appear to be helpless without an elaborate economic system which panders to their "refined" tastes.

The decisive evidence in the association of man and Yahoo follows Gulliver's own observations of the Yahoos and is introduced as an "odd Adventure" which "I hope the Reader will pardon my relating" (p. 250). Then Gulliver telis how while bathing he was sexually attacked by a female Yahoo and was spared the ultimate indigniry only by the appearance of his guardian, the Sorrel Nag (pp. 250-51). During this episode the last barrier between Gulliver's civilized exterior and his Yahoo nature falls with his clothes; naked he is recognized by his own kind. The conclusion is obvious and the Houyhnhnms do not fail to draw it: "This was Matter of Diversion to my Master and his Family, as well as of Mortification to my self. For now I could no longer deny, that I was a renl Yahoo, in every Limb and Feature, since the Females had a natural Propensity to rne as one of their own Species ..." (p. 251).

Even in these passages, however, where the dominant impulse of the narrative is toward the final and conclusive identification of man abd Yahoo, there is a sharp contrast between the observant and clothed Gulliver and the blatant and naked hatred and concupiscence of the Yahoos, despite the fact that Gulliver at times antagonizes the Yaboos in petty ways and thereby seems to descend to their level. His growing hatred of the Yahoo, confirmed in these passages, has the same ironic effect, for he exhibits their antipathy to their own kind. Nevertheless, the gap between Gulliver and the Yahoos, although narrowed in such episodes, never seems to be completely closed. Too many distinctions between man and Yahoo-most of them explicitly to civilized man's great disadvantage and some implictly to his credit-have been drawn. Whether his failure to succumb to the passion of the female Yahoo who attacks him represents a "natural" or an "unnatural" response, it is indicative of the distance between him and these nuisances in the land of the Horses.

The first eight chapters of the fourtl voyage present a complex explanation of a strange state of affairs: appearances notwithstanding, civilized man is a Yahoo worse than the degenerate Yahoos of Houyhnhnmland. And, at the same time, this irony of appearances notwithstanding, Gulliver (and hence 
European man) seems superior to the brutal Yahoos because he can condemn Yahoo vice and can later be capable of exalting Houyhnhnm virtue. The ambiguous dislocations which characterize Gulliver's entry into the world of the Houyhnhnms surely also prepare us for the aralogous ambiguous dislocations which characterize Gulliver's admiration of the Horses and his exile from Houyhnhnmland. Even so, wc may well wonder whether the insights into human nature provided by Gulliver's discoveries anong the Yahoos and Houyhnhnms can entirely obliterate the possibility of human decency and honesty, any more than Gulliver's return to the "normal" world of England at the end of the Travels can utterly obliterate the Houyhnhoms virtues or their enlightened views of humanity.

We are now, I hope, in a better position to understand why there has been so much critical disagreement about the significance of the Yahoo (and perhaps also of the Houyhnhnm). The construction of Part IV of the Travels does not enable readers to fix simple symbolic meanings to Yahoo and Houyhnhnm any more than it enables them to deny that these figures lack significance as symbols.

\section{Notes}

1. On the carly critical fortunes of Part IV of Gulliver see Donald M. Berwick, The Reputation of fothathin Swift, 1781-1882 (1941: rpt. New York: Hiskell House, 1965); Merrel D. Clubb, "The Criticism of Gulliver's "Voyage to the Houyhnhnms' 1726-1914," Stanford Sitclies in Langtage and Literatare: Fifternh Antiversory of the Founding of Stan/ord Univetsity, ed. Hardin Craig (Pialo Alto: Stanlord University Press, 1941), pp. 203-32; Herbert Davis, "Recont Studies of Swilt: A Survey." UTQ. 7 (1938), 273-88; and George Sherburn, "Methods in Bouks about Switt," $S P, 35$ (1938), 635-56. For accounts of recent criticism sec Milton Voigt, Swift and the Twentieth Centary (Detroit: Wayne State University Press, 1964), pp. 65-123; and Jatnes L. Clifford, "Gulliver's Fourth Voyage: 'Hard' and 'Soft' Schools of Interpretation" in Quick Springs of Sense: Studies in the Eighteenth Century, ed. Larry S. Chanipion (Athens: University of Georgit Press, 1974), pp. 33.49. Prufessor Clifford $(\mathrm{p}, 41)$ specifics four "particular questions which seem ... crucial . . (1) the meaning of the Yahoos, (2) the meaning of the Houyhnlinms, (3) the significance of Captain Mendez, and (4) the interpretation of the ending."

All references to Gulliver in this paper ure to the edition of Harold Williams in The Prose Works of Jonathan Swift, ed. Herbert Davis and others (Oxford: Basil Blackwell, 1939-59), XI.

2. See respectively Churton Collins, Jonathan Swift: A Biographical and Critical Study (London, 1893), p. 209; Deane Swift, An Essay on the Life, Writings, and Choracter of Dr. Jonathan Swift, D. D. (London, 1755), pp. 218.21; Thomas Sheridan, The Life of the Rev. Dr. Jonuthan Swift (London, 1787), Pp. 432-37; and C. J. Rawson, Gullit'er and the Gentle Reader: Stadies in Sorfe and Oar Time (London and Boston: Routledge and Kegan Paul, 1973), p. 22. As Professor Clifford ubserves (p. 42), "current theories accept 'the Yahoos' as descriptive limits of which man may degenerate ... or . . . as the orthodox representation of the natural depravity of man."

3. See, for example, Samuel Holt Monk, "The Pride of Lemuel Gulliver," Sewanee 
Review, 63 (1955), 48-71; Irvin Ehrenpreis, The Personality of lonathan Swilt (Cambridge: Flarvard University Press, 1958), pp. 99-109-later modilied in "The Meaning of Gulliver's Last Voyage," REL, 3 (1962), 18-38; and Kathleen Williams, Jonnthan Swift and the Age of Compromise (Lawrence: University of Kinsas Press, 1959), Pr. 154-209. For the view that the Yahous symbolize man's sinfulness see Roland M. Fryc, "Swift's Yahoo and the Christian Synbols for Sin," HHI, 5 (1954), 201-17. See also Clifford, p. 38, пл. 1720 .

4. For this view see R. S. Cane "The Rationale of ulı Fourth Voyage" in Gulliver's Travels: An Annotated Text with Critical Esstys, ed. Robett A. Greenberg (New York: 1961), pp. 301-6; and "The Houyhnhnns, the Yaloos, and the History at Ideas" in Reason and the lmaginution: Stadier in the History of ldeas, ed. J. A. Mazzeo (New York: Columbin University Press, 1962), pp. 251-53. F'or similar views see Edward W. Rosenheim, Swift and the Satirist's Art (Chicago: University of Chicago Press, 1963), Pp. 154-67 and 209-22.

5. Crane, "The Rationale of the Fourh Voyage," pp. 302-3.

6. On the use of the term world to reter to different peints of view or to differing "realms" or "universes" of value or discourse within it single work, sce Martin Price, To the Palace of Wisdom: Saudies in Order and Enorgy from Dryden to Blake (New Yurk: Doubleclay, 1964), pp. 1.27 and throughout.

7. On this topic see my article "Beist over Man: Theriophilic Paradox in Gulliver's "Voyiage to the Country of the Houyhuhnms," 51 , 67 (1970), 532-49.

8. Sec "Benst over Man," 540-42.

9. A similar ambiguity may be discerned in the "clothes plilosnphy" in $A$ Tale of a $T u b$, where in the allegory of the coats, Peter ind Jark in their mutilation of their coats are respectively guilty of the follies of foppery and sloppiness. These trivial and superEcial flaws which bunction as allegorical repiresentitions of departures fram primitive Christianity are symbolic of deeper moral ills - a serious ignorance and contempt of those inward proprieties which are symbolized by the wearing of clothes. The same is true of the Hack in his concern for the "superficies of things," a concern which shows his ignorance of aleeper significance. Ironically, the superficial is inportant in the Tale hecause it is inevitably contuected with underlyuig and derper significance. Thus the Hack's conern with ephenera reveals the nature of his ephemeral mind. See Ronald N. Paulson, Theme and Structure in Swite's "Tale of "Tub" (New Haven: Yale University I'ress, 1960). passim and esp. p.p. 137-44.

10. Gulliver's Master merely begs this question when later be comnents on Europeat dress: "He had therefore begun to think it not unwise in us to cover our Bodies, and by that Invention, conceal many of our Deformities from each oflucr, which would dse be hardly supportable" (p. 244).

11. The development of netaphors which "Break down" is one of Swift's favorite deyices. See, for example, the passage in the Drapier's Letters, Letter III (Works, $\mathrm{X}, 48$ ), where Wood is first magnifed through a comparison wo Goliath and then by a shatp return to the contemporary and unheroic seene of Angla-lrish politics, is defared. Price (Swift's Rhetorical Art, pij. 54-55) says of this passage, "This device, the reductive shift from metaphor to the literal situation, from the field of combat to the Drapier's shop, . . . has the ribetorical effect of pointing to the falsencss of the whole issuc: Wood, unlike Goliath, has no power of his own and is at best a preposteruus instrunent of the English ministry." See alse Maurice J. Quirlan, "Swift's Use of Liternlizacion as a Rhetorical Device," PMLA, 82 (1967), 516-21, for related techniques employed on a smaller scale.

12. The first extensive and very probably still the best explanation of the "ironie reversal" of the symbolism in the first two voyages is that of $\mathrm{H}$. M. Dargan, "The Nature of Allegory as Used by Swift," SP, 13 (1926), 159-79. Also, one might compare Dargan's description of Swites technique with Ejwin Honig, Dark Conceit: The Making of 
Allegory (Evansron: Northwestern Uriversity Press, 1959), pp. 117-32, where Honigg discusses similar techniques under the titkes of the "illegoric waver" and "irony."

13. As several critics have pointed out, there is little use of ditect discourse in the Tratels. For two examples, sec pp. 51-55 and 116.

14. Gulliver hinself, of course, ditects the reader's attention to this aspect of Swift's technique: "My only Concern is, thit I shatl hardly be able to do Justice to my Master's Arguments and Expressions, which must necds suffer by my Want of Calpacity, as well as by a Translation into our barbarous English" (p. 229). And "It put me to the Pains of many Circumlocutions to give my Master a right Idea of whint I spolse; for their language doth not abound in Variety of Words, because their Wants and Passions are fewer than among us" (p. 226).

For a goad disctussion of the problem of narrative print of view in the Tratels, sec Robert C. Elliot, The Power of Satire: Magic, Ritud, Art (Princeton; Princeton University Press, 1960), pp. 189 (f. The point made here is related to Elljott's discussion but not included in it. Elliott distusses some of the implications of the fact that the re are two dominant points of view goversing the Trawels: "Swift has created two dominant points of view to control the materials of the Travels: that of his firvorite ingenu (the younger Gulliver) and that of the misanthrope" (p. 190).

15. The only exception to this general procedure is the pointed description of Lawyers as a "Society of $\mathrm{Mcn}$ " (p. 232).

16. To the degrec that it pruvicles a kind of historical background for such a distinction as this one, R. S. Crane's recent essiny "The Houyhnhnms, the Yahoos, and the History of Ideas" is a hejplul contribution, for he points out that Swift was probably in revolt against the traditional logical definition of man as "animal rationale." But Crane, like many others, takes the acion of Gulliver for granted and aever addresses himself to studying its complexities-a rather futdamental errof. No work of art simply exists: it always proceds. In addition, the background which Crane presents seems to this writer inadequate.

17. See "Beast uver Man," where the Master Houylunhnm's critique of human reason and the theme of the cotropy of civilization are diseussed.

18. It is highly unlikely, for cxample, that Gulliver's general description of a minister of state is not informed by Swift's view of Sir Rober 'Walpolc's administration. Such passages in the fourth voyage merely generalize the topical sitice of kings, courts, and ministers lound in the political allegory of Parts I and III. On this topic see Arthur E. Case, Four Essays on Galliver's Tratels (Princeton: Princeton University Press, 1945), pp. 69-96, and Kathieen Williams, Jonathan Swift and the Age of Compromise, Pp. $165 \mathrm{ff}$.

19. See Elliote's enlightening discussion of narrative point of view in Gulliver (The Power of Sative, Pp. 189 f.), where he obserses (p. 190), "The Gulliver who writes, then, is Gulliver the misanthrope. . . It is he who "erentes' the ship's surgeon. . . . Given the emorional and intellectual inbalance of the old seaman, he is remarkably successful in producing an objective portenit of himstll as he wats in time long prast.

"The actual, as opposed to the fictive, situation, of course, is that Swift has created two dominant points of view to control the materials of the Travels; that of hij favorite ingenu (the younger Gulliver) and that of the misanthrope."

20. Such manipulation of point of view iccuunts for both the savage satire of Chapters $V$ and VI and Gulliver's prutestutions of loyalty to his native land at the beginning of Chapter VIf. "However, it is now sotme Comfort to reflect, that in what I said of my Countrymen, I extentated their Faults as much as I durst before so strict an Examiner; and upon every Article, gave as favourrble a Turn as the Matter would bear. For, indeed, who is there alive that will not be swayed by his Byass and Parciality to the Place of his Birth?" (pp. 242-43). This remark is, of course, ironic since it tends both to impugn Gulliver's veracity during the time of the conversations and to intensify the already severe 
satirc contained in the precis of those same conversations by implying that the criticism of man contained thercin is not so severe as it ought to be.

2I. Pride is the only sin not explicitly noted among the Yahoos, but it is possible that the statement, "the Yahoos were known to hate one another more than they did any different Species of Animals," is indicative of their pride, for "the Reason usually assigned, was, the Odiousness of their own Shapes, which all could see in the rest, but not in themselves" (p. 244). This conjecture seens justified by Gulliver's indictmene of human pride which concludes the Travels: "The wise and viruous Houyhnnms. . . have no Name for this Vice in their Language, which hath no Terms to express any thing that is cvil. cxcept these whereby they deseribe the delestable Qualities of their Yohoos; among which thcy were not able to distinguish this of Pride, for want of thoroughly understanding Human Nature, as it showeth it self in other Countries, where that Animal presides, But I, who had more Experience, could plainly observe some Rudiments of it imong the wild Yahoos" (p. 280).

22. That Gultiver conceives of the Iahoo as being wholly governed by instinct and passion is clear From Gulliver's response to the description of femble Yahoos: "However, I could not reflect without some Amazement, and much Sorrow, that the Rudiments of Letodness, Coguetry, Censure, and Scandal, should have Place by Instinet in Wumankind" (P. 248).

23. The conflict between symbolic significanee of the Yahon and the Master Houyholam's evaluation of the Yahoo in comparison to man corresponds to the technique described by Dargan, pp. $172 \mathrm{ff}$., in the first cwo voyages. For ather descriptions of this technique in literanure, see Honig's description of the "allegoric waver," the oscillation between conflicting meanings of concrete attribute of the syrnbol and symbolic significance (pp. 115-46), and for an interesting application of this principle to Spenser's allegory, see Graham Hough, A Preface to the Faerie Queene (Ncw York: Norton, 1963), PP. 107-37.

I have limited myself to the use of the term "sytnbolism" insterd of using both "symbolism" and "nllegory" logether in the same context because of the widespread but mistaken belief that these two terms refer to techniques which are nuutually exclusive of one another; nothing could be furtber from the truth. As a practical distinetion between the two, one might say that whenever symbols become agents (characters) or when attributes of agents become symbolic, then the conditions required for allegory are net. For refreshingly clear discussion of this puint, see Hough, PP. 100 ff., and see Ilobert Scholes and Robert Kellogg. The Nature of Narrative (New York: Oxford University Press, 1966), Pp. 105 ff., for related notions. 


\section{Dr. Johnson and Cookery}

\section{By GILES Barier}

Dr. Johnson was born in 1709 and died in 1784. His lifetime therefore spans that central part of the eightenth century which saw so many of the economic and social developments contributing to the making of the modern world. Further, we probably know more, through Boswell, of Johnson's everyday life than of almost any other major contemporary figure and it is therefore perhaps valuable to start any consideration of Englisl cooking in this period, and its debt, or otherwise, to French cuisine (a word first used in English in 1786) by investigating the very pcrsonal but not untypical views of Samuel Johnson on food and cookery. It is indeed perhaps surprising that, according to the bibliography of critical studies on Johnson by Professors Clifford and Greene, although articles have been written on Juhnson as a snuff taker, Johnson and tea, on Was Dr. Johnson a smoker?, on Dr. Johnson and gir, Dr. Johnson on winc, as well as on his alcohol problem, nothing has been essayed on his attitude to food and cookery. ${ }^{2}$ A preliminary survey of the subject seems therefore to be called for. A comparison with Diderot and with certain French practices should also enable one to see the English scene in better perspective.

We are of course fairly well informed about Johnson's personal tating habits and predilections. It is true that in Chapman's index to the Letters there is a depressing entry under Food and Drink, reading "There are hardly any mentions of either except in references to diet or to presents of food." But Boswell's $L i f e$ and other contemporary sources present a sometimes regrettably full picture. We know for example that when Johnson first came to London in 1737 at the age of twenty-eight he dined, as he told Boswell, "very well for eight pence, with very good company, at the Pine Apple in New Street. Several of them had travelled. They expected to meet every day; but did not know one another's names. It used to cost the rest a shilling for they drank wine; but I had a cut of meat for six-pence, and bread for a penny, and gave the waiter a penny; so I was quite well served, nay better than the rest, for they gave the waiter nothing." Another anecdote concerning Johnson's dinners at this time is related by Walter Harte, chaplain to the Earl of Chesterfield, who, dining with Edward Cave at St. John's Gate in 1744, praised the Life of Savage, only to be told by Cave at their next meeting that he had greatly pleased Johnson, who had been eating in the same room, hiding belind a screen as he was ashaned to be seen since his clothes were too shabby. "The times were 
indeed to clrange if we consider that in April 1778 Johnson, then in his sixtyninth year, attended fiftcen dinner parties in twenty-three days. ${ }^{5}$

The screen might however have served another purpose for if Lord Chesterfield is said to have described Johnson as "a respectable Hottentot" who apparently "threw his meat inywhere but down his throat" (to which Johnson retorted that Chesterfield had never seen him eat meat) there is also the evidence of Hawkins who reports, "It was, at no time in his life, pleasing to see him at a meal. The greediness with which he ate, his total inattention to those among whom be was seated, and his profound silence in the hour of refection, were circumstances that at that instant degraded him and showed him to be more a sensualist than a philosopher." In a parallel passage in Boswell we find, "I never knew any man who relished good eating more than he did. When at table, he was totally absurbed in the business of the moment; his looks seemed rivetted to his plate; nor would he, unless when in very high company, say one word, or even pay the least attention to what was said by others, till he had satisfied his appetite, which was so fierce, and indulged with such intenseness, that while in the act of eating, the veins of his forehead swelled, and generally a strong perspiration was visible. To those whose sensations were delicate, this could not but be disgusting; and it was doubtless not very suitable to the character of a plilosopher, who should be distinguished by self-command. But it must be owned, that Johnson, though he could be rigidly abstemious, was not a temperate man either in eating or drinking. He could refrain, but he could not use moderntely. He told me, that he had fasted two days without inconvenience, and that he had never been liungry but once. They who beheld with wonder how much he eat upon all occasions when his dinner was to his taste, could not easily conceive what he must have meant by hunger." On his silence at meals we may recall the lines from his translation of Mcdea,
Al, little needs the Minstrel's Power
to speed the light convivial hour
the board with varied plenty crown'd
May spare the luxuries of sound. ${ }^{\text {B }}$

Nevertheless he apparently talked with great contempt of people who were anxious to gratify their palates and even if the gulosity of Rambler 206 is more, as it is subtitled, the "Art of living at the cost of others" he was strenuously opposed to gluttony. In writing to one of Mrs. Thrale's children in 1783 he remarked, "Gluttony is, I think, less common among women than among men. Women commonly eat more sparingly, and are less curious in the choice 
of meat; but if once you find a woman gluttonous, expect from her very little virtue. Her mind is enslaved to the lowest and grossest temptation."

A final sketch of Johnson at table is provided by Boswell in his description of the assiduous attentions of Wilkes helping him to some fine veal. "Pray give me leave, Sir: - It is better here - A little of the brown - Some fat, Sir - A little of the stuffing - Some gravy - Let me have the pleasure of giving you some butter - Allow me to recommend a squeeze of this orange; - or the lemon, perhaps, may have more zest.' - 'Sir, Sir, I am obliged to you, Sir, cried Johnson, bowing and turning his head to him with a look for some time of 'surly virtue', but, in a short while, of complacency."'10

Mrs. Piozzi tells us of Johnson's predilections-"Johnson's own notions about eating however were nothing less than delicatc; a leg of pork boiled till it dropped from the bone, a veal-pye with plums and sugar, or the outside cut of a salt buttock of beef, were his favourite dainties." ${ }^{11}$ Hussy too records that he had more than once allured him to dine with a buttock of beef.

The Tour to the Hebrides provided Johnson with some culinary novelties and his reactions to these are naturally well chronicled. Breakfast in Scotland, consisting of tea, coffee, butter, honey, and conserves he preferred to the current English version. Early on he ate at dinner several platefuls of Scotch broth with barley and peas in it and seemed very fond of it. Boswell, doubtless encouraged, remarked "You never ate it before," and was rewarded by " $\mathrm{No}_{3}$ Sir; but I don't care how soon I eat it again." In fact, Johnson later wrote "Barlcy broth is a constant dish; and is well made in every house. A stranger, if he is prudent, will secure his share, for it is not sure he will be able to eat anything else." Certainly he violently disliked the speldings (or dried and salted whitings), the dried broiled haddock, and the cold sheepshead, the latter offered him for breakfast on Mull. He comments in a letter from Skye: "Their tables are very plentiful, but a very nice man would not be pampered," stressing that as they have little meat they kill what they have and eat it at once, mutton boiled and roasted therefore being served together. With interesting sophistication he goes on, "To sauce in general they are strangers; now and then butter is melted, but I dare not always take, lest I should offend by disliking it." Roast kid was however a novelty of which he approved and he attacked a dish of stewed carp most vehemently "using his fingers only in feeding himself."

Further afield things were even less to Johnson's taste than in Scotland, and after his visit to Paris he described Frencly meals as gross. Unfortunately the only menu given in detail is that for the day he dined with the Benedictines on a fast day so that all they had was "soup meagre, herrings, eels, both in sauce. Fryed fish. Lentils, tasteless in themselves." It is noticeable that Anglo- 
French gastronomic differences were already well established, and if French visitors over here were already complaining that the only British preparation for vegetables was to boil them, Johnson and Mrs. Thrale on the other hand considered that "the cookery of the French is forced on them by necessity," their meat being considered putrified and requiring the famous French sauces to conceal this. Incidentally Johnson saw the French royal fanily at dinner and observed, in a comment which I assume refers to the fork hand, that the king "fed himself with his left hand as we." Johnson's deliberate comment on this seems to imply that others did not do so, presumably a reference to what in Britain is now considered as an American habit, that of cutting up one's meat and then eating with fork alone in the right hand. Engravings of Louis XV at table show some confusion over forks which some are using while others have their right hands in their plates. In one the king mysteriously has his left hand on his plate and is eating with a fork in his right hand. ${ }^{14}$ Knives and forks seem to be laid to the right.

It is noteworthy that nowhere does one find any references to vegetablesnot, it is true, considered important at that date-or indeed to puddings, but it is evident that Johnson's voracious consumption of meat was counterbalanced by his great love of fruit, which he retained virtually to his last days. Malone surprised him of an evening roasting apples before the fire for fun, and in discussing fruit-growing with Boswell, he commends cherries, early apples and pears, and particularly currants, which he remarks are good and make a pretty sweetmeat.

There is, too, the famous incidcut relating to the peel of the Seville oranges, the juice of which he squeezed into the drink he made himself at the Club. The peel was pocketed, dried and scraped. Taxed with this by Boswell he would not reveal why he did it. Boswell then remarked, "Then the world must be Jeft in the dark. It must be said (assuming a mock solemnity), he scraped them, and let them dry, but what he did with then rext he never could be prevailed upon to tell." Johnson retorted, "Nay, Sir, you should say it more emphatically: - he could not be prevailed upon, even by his dearest friends, to tell."' The solution so sought by Boswell, Beauclerk, and Garrick is to be found in Johnson's letter to Miss Boothby of 31. December 1755 when he recommends as a remedy for indigestion an ounce of orange peel, finely dried and divided into scruples (20 grains or a third of a dram) taken every three hours with a glass of hot red port or wine. Cinnamon or nutmeg can be added, he remarks, but "I think using sugar with it would be bad, if syrup, use old syrup of quinces but even that I do not like. I should think better of conserve of sloes." Clearly if he was a voracious eater he neverthcless looked after 
himself and the ill after-effects of his gulosity. As he once remarked, "I mind my belly very studiously, and very carefully; for I look upon it, that he who does not mind his bclly will hardly mind anything else." 18

Clearly his interest in food was considerable and we may therefore wonder how great his knowledge of the subject was. For some indication of this I curned to the Dictionary and found this as rich as one of Johnson's favourite veal pies stuffed with plums. First cvidently one looks up the entry for "cookery" itself. This is defined as "the art of dressing victuals" and later something must be said about the use of the word art in this context but it seems it may well have been suggested by William King's poem of 1708 entitled The Art of Cookery, from which Johnson makes a number of quotations. Here the line "Everyone to cookery pretends" is chosen and backed up with those from John Davies:

Some man's wit

found the art of cookery to delight his sense

more bodies are consumed and killed with it than with the sword, famine, or pestilence.

Victuals are defined as provision of food and merit the note: "Chapman has written it as it is colloquially pronounced:

\section{'A huge great Aagon full I bore \\ and, in a good large knapsack, victles store."}

The main meals of the day are of course present. Breakfast, a very unobserved and rather continental-style meal to our eyes in the eighteenth century, is "the first meal of the day" and illustrated in an intellectual's manner by Prior's lines

As soon as Phoebus' rays inspect us

First, Sir, I read, and then I breakfast.

With twentieth century habits we would next consider lunch, but this meal, as we know it, did not then exist. Indeed Johnson derives lunch and luncheon neither with Minshew from the Spanish louja nor with Skinner from the German kleinken but from clutch or clunch and defines it as "as much food as one's hand can hold," the illustrative quotation being Gay's:

When hungry thou stoods staring, like an oaf,

I sliced the luncheon from the barley loaf,

with crumbled bread I thickened well the mess.

Johnson does however also mention nunchion, "a piece of victuals eaten between meals," supported from Hudibras: 
Laying by their swords and trunchions, they took their breakfasts or their nunchions.

Both these definitjons reflect the babits of the eightecnth century which, while it progressively recognised lunch, especially for the ladies, generally considered it a snack taken between breakfast and dinner which, like Johnson, it considered the chief meal of the day. Dinner, Johnson says, is eaten about the middle of the day. It would in fact be interesting to know what he meant by this, for in his lifetime the normal hour of the meal moved back from twelve noon to Eour p.m., the hour when the Thrales and the hostesses of Evelina dined. ${ }^{17}$ The Club dined at five p.m, in 1970 . In 1723 Magdalen Collcge, Oxford, dined at ten a.m., but in that year St. Edmund Hall moved at least the Shrove Tuesday dinner to noon, a fact Hearne regretted together with the absence of the traditional fritters. As he puts it: "When landable old customs alter 'tis a sign learning dwindles." By 1767 Balliol had moved up to two p.m. lut was evidently still well behind fashion. Supper was naturally the last meal of the day, and again Johnson provides a Shakespearean quotation one feels he must often have used in escaping after dinner:

\section{I'll to my book:}

For yet, ere supper-time nust I perform much work.

Turning to the dressing, or preparing, of victuals for the table we find again a concentration on the treatment of meat and an almost total disregard for vegetables. Soup is "a strong decoction of flesh for the table," broth is "the liquor in which Aesh is boiled," the French terms botillon and bisque are the same, and only pottage, also said to come from the French, is "anything boiled or decocted for food." It is hardly surprising therefore that soupe Tulienne, to be found as such in eighteenth century cookery books, is apparently unknown to Johnson.

All the normal methods of cooking meat are to be found: baking, boiling, broiling (or cooking by laying on the coals), grilling, frying, roasting, and stewing. Preparation can include marinading and meat can be further treated by such apparently foreign methods as being carbonado'd (cut across and broiled on the coals), fricasseed (chicken cut into small pieces and dressed in a strong sauce), or served in a ragoo or hotch pot. The ragout, which Johnson, unlike many contemporary cookery books, spells in the correct French manner, is again noticenbly highly seasoned. The hotchpot, or hoch-pot, or gallimawfry, is derived, with Camden, from "hachte en pot."

Looking through for traditional English dishes, and leaving aside ambrosin or "rhe imaginary food of the Gods" with the passing guery as to what 
their real food was, we come early to apple-tart. This is illustrated by the quotation from Shakcspeare

"What, up and down carved like an apple-tart!" (Taming of the Shretw 4.3.89)

Bacon, "the flesh of a hog salted and dried," brings forth Dryden and "High o'er the hearth a chine of bacon hung," and provides an explanation of the phrase "to save one's bacon" which, it is explained, is borrowed "from the care of housewives in the country, where they have seldom any other provision in the liouse than dried bacon, to secure it from the marching soldiers." A baron of beef rates a technical description, but even if Johnson considers that a beefeater is one whose commons are beef he refers to Stevens' preference for "beaufetier" or waiter at the sideboard.

As we have already seen, the number of foreign phrases is comparatively high. French, as previously Italian, cooking was fashionable and both foreign vocabulary and ingredients are often mentioned in contemporary cookery books. Doubtless Johnson considered many of these dishes to be kickshaws, a word known to Shakespeare and derived by Johnson, apparently correctly, from the French "quelque chose" but which, instead of defining as an elegant but insubstantial thing, he forthrightly explains as "i dish so changed by cookery that it can scarcely be known!" Bisket and macaroon are recorded but macaroni, spaghetti, and noodles are unknown. Vermicelli, regularly imported from Italy at this time, are however "a paste rolled and broken into the form of worms" or, as Prior puts it, "With oysters, eggs, and vermicelli / She let him almost burst his belly." Poupicks or "a mess of victuals made of veal steaks and slices of bacon" are featured, presumably for paupiettes, and, as these were often described in English cookery books as "poupiets," I would almost hazard that the form poupicks represents some misread manuscript note. Another matter of controversy arises over the phrase "to rule the roast," or, as many nowadays consider more logical, "to rule the roost." Johnson defines it as to govern, to manage, to preside and adds "It was perhaps originally roist, which signified a tumult, to direct the populace." I fear that Johnson is not supported by modern experts who, preferring roast to roost and finding it the older form (as roast it first appears in 2 Henry VI), explain it as he who is head of the house carves the meat.

Coming to the end of the meal one turns naturally to the pudding, a food, the Dictionary defines, "variously compounded but generally of meal, milk, eggs" and a distinctly national dish. Johnson again quotes Prior: 


\section{Sallads, and eggs, and lighter fare \\ tune the Italian sparks guitar; \\ And if I take Dan Congreve right \\ Puddling and beef make Britons fight.}

Pies, pancakes, pasties, and pastry all make their appearance although the derivation of pasty leaves Johnson in some doubt deriving it from the French pied since, as he says, in some provinces apple pasty is still called apple foot. Syllabub (or rather sillabub with an i) gets a long entry. "This word," says Johnson, "has exercised the etymologists. Minsheu thinks it corrupted from swillingbubbles. Junjus omits it. Henshaw, whom Skinner follows, deduces it from the Dutch sulle, a pipe, and buyck, a paunch; because sillabubs arc commonly drunk through a spout, out of a jug with a large belly." The first quotation is Erom Wotton:

Joan takes her neat rubbed pail and now

She trips to milk the sand-red cow;

Where, for some sturdy football swain,

Joan strokes a sillabub or twain.

Junkets (from the Italian gituncata for the rush baskets used in straining the milk curds), jellies (spelt with a $\mathrm{g}$ ), and tarts all appear, but no fools, and while sorbile appears there is no sorbet. Tarts are made purely with fruit, and sweetmeats are delicacies made of fruits preserved with sugar and are clearly only for children. Locke however is invoked to say: "If a child cries for any unwholesome fruit, you purchase his quiet by giving him a less hurtful sweetmeat: this may preserve his health but spoils his mind." However, if jam rates but a bare definition the problem of marmalade is different since it evidently has a digestive importance to Johnson. The origin of the word, mucli discussed in The Times in 1974, lies in the Portuguese marmelo or quince, and marmalade is thus said, appropriately enough on the authority of Quincy, to be "the pulp of quinces boiled into a consistence with sugar, it is subastringent and grateful to the stomach." One feels sure that Johnson, pocketing his orange peel, appreciated this although, as we learnt from his letter to Miss Boothby, he did not like syrup of quinces. Before leaving marmalade one should perhaps also mention that the European Economic Community authorities in Brussels issued in 1975 a trade definition for it restricting the use of the word, as in English, purely to preserves based on oranges.

Fruit and some vegetables are recorded fairly fully by Johnson, usually on the authority of some botanical source. An especially large variety of pears are mentioned as well as bananas and pineapples, the latter under both the English 
name and its French form "ananas." If potatoes-of American origin-are particularly Irish, the English are offered a Jarge choice of beans, the latter including the Mozagan (a Porluguese bean from Africa), the small Lisbon, Spanish, and Tokay besides the more homely Sandwich and Windsor beans.

Another eminent lexicographer, a contemporary of Johnson's, who likewise had a keen interest in gastronomy and who, I believe, died eating stewed cherries, was Didcrot. The tale of how he started inserting recipes into the Encyclopédic-such as the seven ways of cooking apricots-until a Jesuit reviewer pointed out that they were all taken straight from Nocl Clomcl's Dictionnaire acconomique, has already been told by Georges May but, even without recipes attached, a number of cooking terms and dishes are mentioned. ${ }^{18}$ In lact a hundred and eleven terms have the subject classification (cuisine) after their entry in the Encyclopedie, together with a further seventeen in the Supplement, while some botanical and zoological entries are also treated from this angle as well. ${ }^{\text {to }}$ Georges May has illustrated, with parallel texts, how Diderot copied his recipes from Clomel but defends him by pointing out that here, as elsewhere, Diderot turned to specialist authorities for his detailed information. He emphasizes further that the inclusion of tecipes is of course typical of the practical turn of mind and of the intercst in manner of execution of trades so inherent in the Encyclopedic.

Professor May also points out that the Frencl editors did not sec eye to eye over this field. The Chevalier de Jaucourt had as usual read both the classical source (Petronius, Plutarch, Martial, Platina) and the more recent technical literature but this left him dryly nostalgic: "La cuisine simple dans les premiets âges du monde, devcnue plus composée \& plus rafinée de siècle en siècle, tantôtt dans un lieu, tantôt dans l'autre, est acruellement une ćtude, unc science des plus pénibles, sur laquelle nous voyons paroître sans ecsse de nouveaux traités sous les noms de Cuisinier Frangois, Cmisinier royal, Cuisitier moderne, Dons de Comus, Ecole des afficiers de la bouche, \& beaucoup d'autres." He even warns his readers further against the dangers of luxury and gastronomy: "A l'égard de la science de la gueule, si cultivée, qui ne s'exerce qu'à tévéiller l'appétit par l'apprêt déguisé des alimens, comme j'ai dit ci-dessus ce qu'on devoit penser de ces sortes de recherches expérimentales de sensualité, je me contente d'ajouter ici, que quelques agréables que puissent être les ragouts préparés par le luxe en tout pays, suivants les principes de la Gastrologie, il est certain que ces ragoûts sont plutôts des especes de poisons, que des alimens utiles et propres à la la conservation de la santé." This cold repugnance to good living, shared, if one is to go by his definitions, by Littré, was not in keeping with Dideror's warmer nature which however equally disliked modern 
fashionable innovations. In the article agneau he wrote "Voilà la vielle cuisine, celle de nos pères. Il n'est pas possible de suivre la nouvelle dans tous ses rafinemens: il vaudroit autant de se proposer l'histoire des modes, ou celle des combinatsons de l'Alchimie. . . Nous ne nous sontumes pas proposés de décrire les manières différentes de denaturer les mots, mais bien celle de les assaisonner."

As is his wont, however, Diderot is good on tools and techniques, but among dishes as wcll quite a number are common to the two lexicographers. For example both mention bisque, bouillon (although the Encycloptlie only gets it into the supplement), carbonado, fricassé, grill, hotchpot, potage, ragout, and puddling. Diderot naturally includes a number of French regional dishes unknown to Johnson such as the plisson du Poitou, the persillade, poivrade, and sauerkraut, but more surprising Johnsonian omissions include omelettes (but present by at least 1792), orangeade, profiteroles, and rissoles, all known to contemporary English cookery books. Of Italian "pasta" each compiler includes but one: Johnson vermicelli, Diderot macaroni. Johnson includes the French paupiette, absent from the Encyclopédie.

It is evident that neicher compiler has really made a systematic survey of cooking for his dietionary or encyclopaedia. Diderot we know covcred certain fields with care, sometimes consulting named specialists, as in the case of printing or typography but bere, as with Johnson, inclusion and definitions scem purely to reflect selection from various sources. De Jaucourt, as we have seen, quotes classical sources and clearly knows the leading French cookery books of his day, but there is little sign that they were used in compilation. Diderot used Chomel in the same way in which Johnson turned to botanical and medical reference works such as Philip Miller's Gardener's and Florist's Dictionary (1724) and Dr. John Arbuthnot's Essay Concerning the Nattre of Aliments (1731). However the basis of Johnson remains literary, and quotations come from Bacon, Dryden, Locke, Prior, and Shakespeare.

A spectal case naturally of interest to, and used by, Johnson was William King's The Art of Cookery; In Imitation of Horace's Art of Poctry (1708). This earjiet William King should not be confused with the later famous Principal of St. Mary's Hall, Oxford, who presented Johnson with the University's M.A. diploma in 1755. King's poem is perhaps disappointing from our point of view but may serve as an example of the cautious British view of foreign cooking. King comments on certain new foods (e.g. mangos) but pleads for traditional cooking:

That Cook to British Palates is compleat, whose sav'ry Hand gives turns to common meat. 
Foreign fashions are suspect even if revered of old, and of the French he writes:

Oh! How would Homer praise their Dancing Dogs,

Their stinking clicese, and Frycasee of Frogs?

Be not too far by Old Examples led,

With Caution now we in their footsteps tread.

The French our Relish help, and well supply

The want of things too gross, by Decency.

Our Fathers most admired their sauces sweet,

And often asked for sugar with their meat;

They buttered Currents on fat Veal bestowed,

And Rumps of Beef with Virgin Honey strowed.

Insipid 'Taste, Old Friend, to them whom Paris know,

Where Roccombole, ${ }^{20}$ Shalott and the Rank Garlic grow.

Concluding, King pleads for a classical care and judgement:

We must submit our 'Treats to Criticks view

And every prudent Cook should read Bossu."

Poets and pastrycooks will be the same

Since both of them their images must framc.

In fact two contradictory tendencies can be observed in the contemporary atticude toward cooking. On the one hand there is the fashionable reverence of French culture responsjble for the translation of most standard French works from De la Varenne's The French Cook (1653) to Menon's The Art of Modern Cookery Displayed (1767) and beyond, not to mention those written in English by French cooks in the service of the English nobility, such as Monsieur de St. Clouet, sometime cook to the Duke of Newcastle. On the other hand the increasing numbet of cookery books catering for the prosperous middle class tended to pour scorn on wasteful foreign concoctions and to stress their native and even regional charncter. Hannah Glasse's famous $A r t$ of Cookery Made Plain and Easy (1747) says, "But if Gentlemen will have French cooks they must pay for French tricks" and later works are called chauvinistically The British Housewife, the British Jewel, or The English Art of Cookery.

In considering the important changes in the culinary field over this period we must note that from a strictly technical point of view there were virtually none in tools or processes. Diderot refers to "le digesteur de Papin," the predecessor of the pressure cooker, the frst description of which was entitled A New Digester or Engine for Softening Bones (1681) and dedicated to the 
Royal Society. However the eighteenth century kitchen, while increasing the accommodation, such as cupboards, shelves, or hot-air-driven spits, remained essentially one where cooking was done either by spit before an open fire or in a cauldron hung over it. Count Rumford's invention of the bricked-in stove with iron plates on top, which heralds the nineteenth century range, came only in the seventecn nineties.

If technical change lagged behind, however, social change was undoubtedly apparent. There was a marked evolution of social politeness. Verbal refinement at table was accompanied by increased sophistication in table setting, cloths were cleaner, plates and cutlery improved. We have seen that Johnson commented on Louis XVI's use of the fork. In particular public eating became more acceptable socially, and this, in its turn, generalised a greater sophistication in cooking. In France it was particularly noticeable that the grandiose public dinners of Louis XIV gave way to the intimate supper parties of Louis XV, Madame de Pompadour, and some sixteen other guests. The king inaugurated a "salle à manger" in the Petits Cabinets in 1735, and it was then considered quite an innovation to have a room reserved for such a purpose.

In France the first restaurant proper is said to have opened in 1765, and within two years Diderot had visited this new institution where the great advantages were the customer's choice of alternative dishes, the individual's choice of hour, and above all the separate tables. The Revolutionary period consecrated the restaurant and by the time Brillat-Savarin wrote his La Physiologie du Gont he could devote the whole of Mćditation XXVIII to restaurants and public eating in this manner.

The word "restaurant" is only recorded in English from 1827, two years after the publication of La Physiologie du Goutt, and Johnson's later dinners were still largely privatc occasions. Although conscious of change he bclonged to the generation before the restaurant and to the social world of the coffee house and the club. But these developments, to flourish after the Revolution, started in his lifetime. Johnson might not have shared Brillat-Savarin's worship of Gastéréa as the tenth muse but he certainly considered that every man should think seriously about culinary matters. Mrs. Piozzi recounts that he often said "that whenever a dinner" is ill got there is poverty, or there is avarice, or there is stupidity; in short, the family is somehow grossly wrong: for a man seldom thinks with more earnestness of any thing than he does of his dinner; and if he can not get that well dressed, he should be suspected of inaccuracy in other things." ${ }^{\text {"22 }}$ His attention to the subject had also led him to comparisons and judgements, and he deemed himself to be a fair connoisseur. He once replied to one of his hostesses: "I, Madam, who live at a variety of good tables, 
am a much better judge of cookery, than any persoln who has a tolerable cook but lives much at home for his palate is gradually adapted to the taste of his cook; whercas, Madam, in trying by a wider range I can more exquisitely judge."2k

Once indeed he even went further and said that he could write a better book of cookery than had ever been written; it would be a book on philosophical principles. ${ }^{2.1}$ Would that we had such a book! In the cliscussion that followed on this occasion, Mrs. Glasse's book was mentioned but Johnson was of the opinion: "Women can spin very well; but they cannot make a good book of Cookery." He liad looked into Mrs. Glasse's book and found errors in it, for example, in the differentiation of salt-petre and sal-prunella. [Ch. XIX: "To Make Anchovies"]. Such books were however usually made by transcription and thus mistakes occurred. "But you shall see what a Book of Cookery I shall make?" he exclaimed, "Pharmacy is now made much more simple. Cookery may be made so too. A prescription which is now compounded of five ingredicnts, had formerly fifty in it. So in cookery, if the nature of the ingredients be well known, much fewer will do. Then as you can not make bad meat good, I will tell you what is the best butcher's meat, the best beef, the best pieces; how to choose young fowls; the proper season of different vegetables; and then bow to roast and boil, and compound."

Johnson's recipe for a cookery book sounds both practical and enticing. One regrets bitterly that he never wrote it. Maybe his friends and contemporaries thought that the philosopher should-to quote Jolnnson's translation of Horace-

behold with scornfull eye

The studied arts of Luxury, ${ }^{26}$

but Johnson nonetheless enjoyed his food and gave cookery an honourcd place.

His views were serious and vehement and his discourse on the subject even led Boswell to see hin as "Jean Bull philosophe." It is Boswell who uses the phrase "the science of cookery" but, as we have seen from his comparison with the contemporary advance of chemistry, the concept was Johnson's, here anticipating Brillat-Savarin. Perhaps in his not writing his cookcry book the world lost a seminal masterpiece, the claboration of another Scienza nuova, that of cooking. Johnson on cookery would at lcast have been a book the author would have had plcasure in writing. If Italian cooking dominated the Renaissance, Frencl cuisine attained to supremacy in the seventeenth century and has remained ever since as the most fashionable even in an England of very international tastes. In the eighteenth century culinary attitudes on both 
sides of the Channel reflect not only these fashions but also, in a minor way, the trend towards bourgeois jnterests, to simplicity, to nationalism, to colonialism, to social evolution, and to other general aspects of the eighteenth century.

\section{Notes}

1. J. L. Clifford and D. J. Greene, Samuel Johnson, a Survey and Bibliography of Critical Studies (Minneapolis: University of Minnesota Press, 1970). Some information on Johnson's atlitude to foud is to be found in Christopher Hibbert, The Personal History of Samuel Johnson (New York: Harper, 1972).

2. The Letters of Samuel johnson, ed. by R. W. Chapman (Oxford: Oxford University Press, 1952), 3 vols.

3. James Boswcll, Life of Johnson, Oxford Standard Authors (Oxford: Oxford University Press, 1965), p. 75 (1737).

4. R. H., Gendemin's Magazine (Dec. 1799), 1018-19.

5. M. Lets, "Dr. Johnson Dines Out, the Record of a Strenuous Month (April, 1778)," Counhill Magazine, n.s. 59 (1925), 319-23.

6. Boswell, Life, p. 189 (1754); and Sir J. Hawkins, The Life of Samal Johnson (London, 1787), p. 354 .

7. Boswell, Lifc, p. 331 (5 Aug. 1973). See atso p. 1121 (March 1781) and Johnson's Dictionury under abstinence, (2) "lasting or furbearance of necessary food. It is generally distinguished from temperance.

Say, can you tast? Your stomachs gre too young

And abstinence engenders maladies.

\section{(Shakespeare, Love's Labouns Lost)"}

8. Samuel Jahnson, The Complete English Poums, ed. 1. D. Fleetran, (Harmondsworth: Penguin, 1971), p. 137.

9. Johnson, Lethers, No. 872.

10. Boswcll, Li/e, p. 768 (15 May 1776$)$.

11. H. L. Piozzi, Anedoles of the Late Satmitel johnon (Londou, 1786), p. 102.

12. Boswell, Lije of Johnon, tal by G. B. Hijh, revised by L. F. Powell, (Oxford: Oxford University Press, 1950), V, 55, 87, 131, 536.

13. The French Journols of Mrs. Thrale and Doctor Johnson, ed. by M. Tyson and H. Guppy. (Manchester: The University and Join Rylands Library, 1932), p. 176.

14. Historia, Hors serie $42(1975)$, p. 65. The date is alsout 1730.

15. Boswell, Life, p. 602-3 (1 April 1775).

16. Ibid., P. 331 (5 Aug. 1763).

17. For information on the hour of meals see Arnold Palmer, Movable Feasts (Lon. don: Oxford University Press, 1952).

18. Georges May, Oratere wisages de Dethis Diderot (Paris: Boivin, 1951), pp. 13-33.

19. R. N. Schwab et al. "Inventory of Diderot's Encyclopédie," Studit's on Voltaire and the Eighteenth Centwy (Banbury, 1971), pp. 80, 82, 84.

20. Rocambole, defined in the Ditionary as a wild or Spanish garlic, reappears as the proper name of an extravagant and unbelievable dyaracter in the novels of the French ninereenth century author Ponson du Terrail, hence "rocambolesque" has taken the meaning "Gantastic" in modern French.

21. R. Le Bossu (1631-80), author of Traite du Poeme Epique (1675).

22. Piozzi, Anecdotes, p. 149.

23. Boswell, Life, p. 332 (5 Aug. 1763).

24. Boswell, Life, p. 942 (15 A pril 1778).

25. Jolnson, The Complete English Paems, p. 35. 


\section{Antisentimentalism in Goldsmith's \\ The Good Natur'd Man: the Limits of Parody}

By Oliver W. Ferguson

The traditional account of the English stage in the 1760 's and 1770 's as an arena for the contrasting cypes of comedy desigmated as "sentimental" and "laughing" includes at least three misreadings of the theacrical history of the period. The first two of these-that sentimental comedy was dominant and that it was displaced, at least temporarily, by the plays of Oliver Goldsmith and Richard Brinsley Sheridan-have been authoritatively corrected, though they may still be cncountered. The third-that Goldsmith's earliest play, The Good Natur'd Man, was written as an attack on sentimental comedy-has not even been challenged. "Everyone knows," according to Robert Heilman, "that Goldsmith intended The Good Natw'd Man . . . as an answer to and criticism of the dominant sentimental comedy." Ricardo Quintana makes no claims for the dominance of either type, but he calls The Good Natu" $d$ Man "an out-andout satire of sentimental comedy." Earlier, Austin Dobson had said that Goldsmitli"s play was his "practical and individual protest against" the genre. And most recently G. S. Rousseau has assumed that "it was universally understood that Goldsmith's purpose in writing . . . [The Good Natur'd Man and She Stoops to Conquer] was to depose sentimental comedy from its stronghold."2

To question this established opinion may seem perverse, or at the very least idle. Goldsmith, after all, is the author not only of the designedly antisentimental She Stoops to Conquer but also of what has become the best-known critical attack on sentimental comedy in the eighteenth centerry, An Essay on the Theatre. Furthermore, the accepted view of The Good Natur'd Man would seem to be justified by the play's theme and plot. Honeywood, the central character, is the victim of a computsion to aid distress whenever he meets it. His benevolence, his anxiety to pleasc everyone, and his refusal to allow uncomfortable realities to qualify his benign view of the world about him ar pathological; and before the play is over, his "grood nature" has almost $\mathrm{d}$ stroyed him. However, hecause his faults arise from good will and are "so nearly allied to excellence," he is wottl reclaiming. His uncle, Sir William Honeywood, who throughout the play has been "a concealed spectator of . . [his nephew's] follies," contrives and then resolves difliculties that show the young man the dangers of his outlook and conduct. The final scene presents a chastened Honeywood in possession of fortune and true love and-most important-an intelligent attitude toward benevolence. 
Honeywood's painfully acquired ethical view is obviously incompatible with the kind found in sentimental comedy. But it is the intentions governing Goldsmith's first comedy, not the fact of his antiscntimentalism, that are in question. And the distinction is worth making, because the misunderstanding of Goldsmith's intentions in The Good Natu'd Man has resulted in a criticism that has not only been damaging to the play itself but has also affected the assessment of Goldsmith's seriousness as an opponent of the sentimental ethic. Some critics have argued that despice the professed theme of The Good Naturd $M a n$, the play's dénouement is no different from that of the typical sentimental comedy. The reclaimed and rewarded Honeywood, they say, is indistinguishable from the similarly redeemed dramas of the period. These same critics have pointed out various other details in the play which, considered along with its happy resolution, appear to support the charge that The Good Natur'd Man resembles the very sort of comedy it is supposed to be repudiating. As Arthur Friedman expressed this view in a recent essay, "Goldsmith's attack on the doctrine of good nature . . . is not so thoroughgoing an attack as at first it may seem."

Robert Heilman argued against this sort of criticism a generation ago. He had no diffculty in demonstrating Goldsmith's rejection of the world view that obtains in the usual sentimental play. Because, however, he undertook his argument with the assumption that The Good Naturd Man was a deliberate attack on sentimental comedy, he was also obliged to justify seemingly inconsistent details in the play and to account for the various features which Goldsmith's comedy has in common with the rival genre. He did so by arguing that these resemblances to sentimental comedy were intended "to provide the materials for satire." The Good Natur'd Man, in other words, attacks the genre by parodying it. This reading of Goldsmith's play las been most vigorously asserted in our day by Quintana, who insists that unless The Good Nattr'd Man is recognized as a parody of sentimental comedy, it 'becomes a rather silly and confused affair, partaking unconsciotsly of the sentimentalism which ic laughs at."

On the face of it, this is an attractive theory. It absolves Goldsmith from responsibility for any taint of sentimentalism in the play; indeed, it not only disinfects such suspected passages, it also endows them with the virtue of satiric intent. This interpretation does, however, raise some objections. For one, how is it that Goldsmith's contemporaries misunderstood his intentions on so crucial a point? Quintana assures us that eighteenth-century audiences mistakenly supposed "that the reform of the hero-from benevolism to anti-benevolism! -was intended to bring the play to a touching conclusion." 7 Critics were 
similariy obtuse if the earliest reviews can be considered reliable. The reviewers For the Monthly Revieu', the Critical Review, the London Magazine, the St. James's Chronicle, and the Gentleman's Magazine reacted variously to Goldsmith's comedy; but they were apparently alike in their inability to understand it.

There is a more fundamental objection to reading The Good Natur'd Man as a parody, an objection that has to do with the nature, the uses, and the limits of parody itself. While it is capable of a number of variations, parody achieves its effects by means of incongrusous imitation. One of the best examples in Goldsmith's work occurs in Act II of She Stoops to Conquer, when the awkward Marlow stammers scntimental clichćs to Kate Hardcastle. The situation itself is parodic: Marlow, who is brazenly assurcl around barmaids and servants but speechless in the presence of Jadies of quality, is Goldsmith's comic version of that dramatic stereotype, the good-hearted rake. As Marlow attempts to engage in sentimental discourse with Kate, the dialogue of a typical sentimental comedy is parodied by the manner in which it is presented; and no one familiar with the serious model can be unaware of its comic distortion in Goldsmith's hands:

Miss Hardcastle. I have often been surprized how a man of semtiment could ever admire those light airy pleasures, where nothing ever reaches the heart.

Marlow. It's-a disease- of the mind, madan. In the variety of tastes there must be some who wanting a relish-for-utn-a-um.

Miss Hardcastle. I understand you, Sir. There must be some, who wanting a rclish for refined pleasures, pretend to despise what they are incapable of tasting.

Marlow. My meaning, madam, but infinitely better expressed. And I can't help observing-a-

Miss Hardcastle. ... You were going to observe, Sir-

Marlow. I was observing, madam--I protest, madam, I forget what I was going to observe.

Quintana bases his argument for a parodic reading of The Good Natur'd Man on the play's conclusion: "A life-long foe of litcrary sentimentalism," he writes, Goldsmith "could adopt the sentimental style when it served his purposes to do so--witness the dialogue that brings The Good Natur'd Man, an antisentimental comedy, to a familiarly sentimental close." When we turn to the scene, we indeed find the happy ending characteristic of sentimental comedies: Sir William points the moral of the tale; Honeywood acknowledges the 
etror of his former way of life and is accordingly rewarded with Miss Richland, whom he has loved in silence for four acts; even a minor character, the scheming Lofty, announces his intention to reform. But when, following Quintana's suggestion, we examine the dialogue of the scene, we find Sir William lecturing Honeywood in these terms:

I own that a desire of correcting your follies led me hither. I saw, with indignation, the errors of a mind that only sought applause from others; that easiness of disposition, which, tho' inclin'd to the right, had not courage to condemn the wrong. I saw with regret those splendid errors, that still took name from some neighbouring duty. Your charity, that was but injustice; your benevolence, that was but weakness; and your friendship but credulity. I saw, with regret, great talents and extensive learning, only employed to add sprightliness to error, and encrease your perplexities. I saw your mind with a thousand natural charms: but the greatness of its beauty served only to heighten my pity for its prostitution.

And when Honeywood vows to mend his ways, he speaks in this vein:

Yes, Sir, I now too plainly perceive my errors. My vanity, in attempting to please all, by fearing to offend any. My meanness in approving folly, lest fools should disapprove. Henceforth, therefore, it shall be my study to reserve my pity for real distress; my friendship for true merit, and my love for her, who first taught tne what it is to be happy. $(V, 81)$

Now, there is undeniably a resemblance between this stilted discourse and the dialogue of sentimental drama, but where are the telltale signs of parody -to say nothing of the comedy that we normally associate with the device? There are no clues in the style, the phrases and rhythms of Goldsmith's prose or the manner of its presentation; there is nothing here comparable to the sentimental dialogue between Marlow and Kate. Nor does the context of Honeywood's words suggest a parolic aim, as it did in the scene from $S$ he Stoops to Conquer. Nothing in the dramatic situation instructs us to read Sir William's and Honeywood's remarks as absurd. On the contrary, at this juncture of the play we expect speeches of this sort. If, then, this is a parody, how can we distinguish it from the genuinely sentimental scene? In what way is Goldsmith's imitation incongruous?

Quintana apparently feels that Goldsmith's inexperience as a dramatist was responsible for the failure of critics and audiences and readers to grasp his point. The Good Natur'd Man, he argues, is "badly faulted [because] . . the 
true ironic intent of the entire piece remains masked throughout. . . Goldsmith's . . parody of the sentimcntal play comes so close to being the thing that it is deriding that it fails to make its point in the theatre, where too great a degree of subtlety is fatal." Goldsmith was beyond question inexperienced as a playwright when he wrote his first comedy. He had much to learn, and the distance between The Good Natur'd Man and She Stoops to Conquer must be measured in more than years. But Goldsmith also knew a grcat deal. After all, The Good Nattr'd Man was written in the tenth year of an active, varied, and by that time highly successfu! literary career. Theatrical inexperience notwithstanding, the uses of parody were hardly unfamiliar to the author of The Citizen of the World and The Vicar of Wakefield.

For that matter there is one brief conversation in The Good Natur'd Man that does parody sentimental dialogue-too slight and incidental to the design of the scene to warrant reading the entire play as Goldsmith's ironic version of a sentimental comedy, but sufficient to demonstrate that in 1767 he knew how to write recognizable parody. In Act III Honeywood is arrested for debt, and to keep this embarrassing circumstance from his friends, he passes the attending bailiffs off as visiting gentlemen. In the scene in which the bailiffs agree to cooperate witl his scheme, there is this exclange:

Honeyw. Tenderness is a virtue, Mr. Twitch.

Bailiff. Ay, Sir, its a perfect treasure. I love to see a gentleman with a tender heart. I don't know, but I think I have a tender heart myself. If all that I have lost by my heart was put together, it would make abut no matter for that.

Honeyw. Don't account it lost, Mr. Twitch. The ingratitude of the world can never deprive us of the conscious happiness of having acted with humanity ourselves.

Bailiff. Humanity, Sir, is a jewel. Its better than gold. I love humanity. People may say, that we, in our way, have no humanity; but I'll shew you my humanity this moment. There's my follower here, little Flanigan, with a wife and four children, a guinea or wo would be more to him, than twice as much to another. Now, as I can't shew him any humanity myself, I must beg leave you'll do it for me. $(\mathrm{V}, 46)$

Here, as in the conversation between Marlow and Kate, Goldsmith is mocking typical sentimental cant. Both the situation and the manner in which the sentimental discourse is presented (the bailifs' mean appearance and Twitch's inelegant accent) make the parody unmistakable. If Goldsmith had had a similar aim in the final scene of the play, he had the ability to make his point clear-and his parody funny. 
The attempt to read the conclusion of The Good Natur'd Man as Heilman and Quintana rccommend extends the device of parody beyond manageable limits. We are left uncertain not only how to differentiate the play from unabashedly sentimental comedies but also how to read comparable modes of expression elsewhere in Goldsmith's works. Goldsmith could and did, as Quintana says, adopt a sentimental style when it suited his purpose, but he could also write at a thetorical pitch that is often too high for twentiethcentury tastes. To label such passages as parody is to assume a critical attitude that is anachronistic and presumptuous. A good example (too long to quote here) of Goldsmith's high-flown style is the essay, "A City Night-Piece." Here is a briefer illustration in the same vein: "As the reputation of books is raised not by their freedom from defect, but the greatness of their beauties; so should that of men be prized not for their exemption from fault, but the size of those virtues they are possessed of." This speech-which sounds very like one of Sir William Honeywod's-is from The Vicar of Wakefield. The speaker is Sir William Thornhill, whose role as deus ex machina and exemplar of the novel's theme, is unambiguous. ${ }^{10}$ However pompous they may sound, his words could not conceivably be read as parody. Here is another example: "Charles, Charles, how hast thou deceived me." Again, however the words might seem to us to demand it, their context makes a parodic reading impossible. The speaker is Marlow's father, and he utters the exclamation on finding his son wooing Kate, for whom he had earlier expressed indifference. Parody here would be pointless; there is simply nothing in the dramatic situation to parody.

Passages of this sort can be found throughout Goldsmith's works. The reason is that Goldsmith was writing not parodically but stereotypically. An obvious characteristic of his prose style is the recurrence of common themes, approaches, and methods of development and of stereotyped words and expressions. An awarencss of this fact should make us cautious with our generalizations about Goldsmith's parodic use of a "sentimental style." In Act IV of She Stoops to Conquer, we know immediately that Marlow's "By heaven, she weeps," is parody, not because of what we might call the extravagant diction but because Marlow's words are inaccurate: he is deceived by the appearance of a Kate who, the stage directions tell is, is "pretending to cry" $(\mathrm{V}, 185)$. On the other hand, the elder Marlow's "How hast thou deceived me" is a stereotype. In The Vicar of Wakefield, Arabella Wilmot exclaims, "O goodness, how have I been deceived," as does Honeywood at the end of The Good Natur'd Man (IV, 174; V, 81). In none of these instances does the situation or the manner of presentation alert us to a parodic intent.

When we recognize the frequency of such stereotyped phrases in Gold- 
smith's prose, we should not attach undue importance to passages which bear only a verbal resemblance to the language commonly found in plays and novels (sentimental or not) of the period. Instances of this sort in The Good Natur'd Man become even less significant (and interesting) when wc realize that in writing the play, Goldsmith was concerned not with parodying sentimental drama but with treating in the form of a conventional comedy a subject of abiding interest to him: the dangers of untutored benevolence. As early as 1759, in a letter to his brother Henry, he described his situation in words that could have been uttered by Honcywood in the last scene of The Good Natur'd Man: "I had learn'd from hooks to love virtue, before I was taught from experience the necessity of being selfish.... and often, by being even from my narrow finances charitable to excess, I forgot the rules of justice, and placed myself in the very situation of the wretch who thank'd my bounty."11

Goldsmith gave this problem literary expression in various gentes throughout his career. Heilman noted its presence in the essay, "On Justice and Generosity" Man-hater, Sir William Thornhill, and Richard Nash. Of all Honeywood's antecedents, however, the most pertinent is found in The Citizen of the World, in the person of Mr. Drybone, the Man in Black-most pertinent because he, like Honeywood and unlike Nash or Asem or Thornhill, is presented in comic terms. Reared by a foolish father to be "a mere machine of pity," Drybone is cast into a predatory world where he is an ensy mark for everyone he encounters, all of whom exploit and then dismiss him with the contemptuous phrase that forms a litany throughout Drybone's recital of his history: "my friends were now perfectly satisfied that I was undone, and yet they thought it a pity for one who had not the least hatm in him, and was so very good natured" (II, 114-18). The phrase and the condescending tone are cchoed eight years later by two characters discussing Honeywood's impending ruin:

Lofty. The man, to be sure, was immensely good natur'd. But then I could never find that he had any thing in him.

Mrs. Croaker. His manner, to be sure, was excessive harmless; some, indeed, thought it a little dull.

Because of the similarity in Goldsmith's handling of the samc theme in The Good Natur'd Man and the history of the Man in Black, his resolution of Drybone's and Honeywood's dilemma is especially interesting. Although Drybone assures his companion that he has broken his habit of uncritical benevolence, we know from his actions and his companion's comments that his reformation is only professed, that "he is generous even to profusion," and that 
his charity is still "rather the effect of appetite than reason."13 Had Goldsmith intended the resolution of The Good Natur'd Man as a parody of the tidy and secure wotld of sentimental comedy, he could have achieved his aim effectively by treating Honeywood as he had done Drybone. But Honeywood's reformation is genuine, and thete is no hint in our final view of him that it will not be lasting.

\section{ii}

The assertion that Goldsmith designed The Good Natur'd Man as an antisentimental cornedy was apparcntly first made by William Cooke in 1805: "Dr. Goldsmith was the frst to attack [sentimental comedy], by his successive productions of The Good Natured Man and She Stoops to Conquer."14 Cooke's opinion would be of more value had it been delivered at some time nearer the theatrical season of 1768-or at least before the production of She Stoops to Conquer. Goldsmith's second comedy has had much to do with the accepted view of his intentions in his first. Two other compositions that have helped establish that view ate the Preface to The Good Natur'd Man and, after the work was first attributed to Goldsmith in 1798 , An Essay on the Theatre. ${ }^{15}$

Goldsmitl's preface to The Good Natur'd Man, which was written the evening the play opened at Covent Garden 29 January 1768, and published the following week, was occasioned by circumstances surrounding the production. The play was moderately successful. There was a fairly even mixture of favorable and unfavorable criticism in the newspapers and magazines, and by the end of the season there had been eleven performances. ${ }^{15}$ Goldsmith's pleasure in this success, however, was marred by two events. One was the notoriety which the play gained because of the bailifs' scene. The first-night audience objected so strenuously to this instance of low comedy that Goldsmith was forced to delete the episode from subsequent performances. His anger at this incident was aggravated by the acclaim which had greeted another new comedy, Hugh Kelly's False Delicacy. Kelly's play had opened at Drury Lane a week earlier, and it was enioying an extravagantly favorable reception.

False Delicacy is by no means uncritical of some of the excesses of sentimentalism. Nor is it devoid of laughter. It contains two humorous characters and some genuine, if not compelling, comic scenes. Nevertheless, it embodies all the significant features of sentimental comedy, and it was for these that the reviewers were praising it. One, writing in the St. James's Chronicle, compared the new comedics playing at Covent Garden and Drury Lane, approving of both and noting their striking differences: "If the Drury-Lane Comedy is more refined, correct, and sentimental, the Covent-Garden performance is more 
bold, more comick, and more characteristic [i.c., presenting vivid characterization ]." The reviewer congratulated the public for being "at once in possession of two such comedies," but Goldsmitl did not share his sense of good fortune. Not only was the more successful play being applauded for precisely the qualities his own comedy lacked, but also his rivalry with Kelly was complicated by other factors. Goldsmith had first sulbmitted his play to Garrick. It was only after Garrick's continued unwillingness either to accept or rcject the manuscript that Goldsmith gave it to George Colman, the new manager at Covent Garden. Thus, even before the 1768 season onened, False Delicacy and The Good Natur'd Man were cast in competing roles. For a final complication in this chapter of theater history, until their public confrontation in 1768, Kelly and Goldsmith had heen Ericnds. ${ }^{18}$ The assessmont of the sicuation by Goldsmith's biographer, Sir Tames Prior, is a triumph of understatement: "Two comedies appearing nearly at the same moment at the two houses, of professedly opposite styles and merits, necessarily involved a kind of rivalry between the authors; and the continual discussions to which they gave rise when theatrical affairs were of general interest, their publication within three days of each other, their progress step by step through the press, a fourth edition of each being called for about the same time, produced at length something like jealousy."

It is against this background that Goldsmith's preface must be read. The substance of the brief piece is in its first paragraply:

When I undertook to write a comedy, I confess I was strongly prepossessed in favour of the poets of the last age, and strove to imitate them. The term, gentecl comedy, was then unknown amongst us, and little more was desired by an audience, than nature and humour, in whatever walks of life they were most conspicuous. The author of the following seenes never imagined that mote would be expected of him, and tberefore tn delincate character has been his principal aim. Those who know any thing of composition, are sensible, that in pursuing humour, it will sometimes lead us into the recesses of the mean; I was cven tempted to look for it in the master of a spunging-house: but in deference to the public taste, grown of late, perhaps, too delicate; the scene of the bailiffs was retrenched in the representation. In deference also to the judgment of a few friends, who think in a particular way, the scene is here restored. The author submits it to the reader in his closet; and hopes that too much refinement will not banish humour and character from our's, as it has already done from the French theatre. 
Indeed the French comedy is now bccome so very elevated and sentimental, that it has not only banished humour and Moliere from the stage, but it has benished all spectators too.

Though he does not mention Kelly's play, Goldsmith obviously has False Delicacy in mind as the kind of genteel comedy that threatens to banish humor from the stage. It is equally obvious that the Preface is his direct response to the hostile reception given the now-restored bailiffs' scene on the opening night of The Good Natw'd Man. Arthur Murphy has fixed the time of composition precisely. The upper gallery, he recallcd, hissed the scene, and "from that hiss Goldsmith was in the dining room of Griffin the Bookseller . . . madly appealing to Posterity. He had before him three different Prefaces, in all of them appealing to Posterity. He was in Great Distress of Mind. I told him that if $\mathrm{He}$ would Let me, I could Easily deliver him from his difficulties. . . . and accordingly I Extracted a short sober Preface out of his blotted Papers, and Left out the appeal to Posterity. He was very tharkful."20 Given all the circumstances, it is hardly surprising that Goldsmith's preface is an aggressive defense of the rejected scene and that as such it is clevored exclusively to a justification of low comedy. When, five years later, Goldsmith wrote a play deliberately attacking sentimental comedy, his manner of proceding was altogether different. In An Ersay on the Theatre, written in preparation for the appearance of She Stonps to Conquer, he examined the various aspects of sentimental comedy -its rationale, its aim, its shallow characterization and empty dialogue, its proscription of low humor. It is this essay, and not the Preface to The Good Natur'd Man, that has become the locus classicus for Goldsmith's opinion of laughing and sentimental comedy. Far from being a major statement of artistic intent, the earlier document is a narrowly limited occasional piece, prompted by commercial rivalry, envy, and chagrin.

iii

To recognize that Goldsmith did not write The Good Natu'd Man as a satire on sentimental comedy will not obviate the play's faults. The unredemable dullness of all the serious characters is the principal one, and there are others. They do not, however, include oversubtle parody or unconscious sentimentalism. There is no justification for calling The Good Natur'd Man a Aawed attack on sentimental comedy. Still less will a recognition of Goldsmith's aim in his first play deny his consistent opposition to sentimental comedy. An author may choose to reject a literary style instead of parodying it. If Goldsmith's play is read on its own terms and not as the opening shot in a battle against the sort of comedy represented by False Delicacy, it will be 
seen that The Good Natn'd Man, like Kelly's play, is a conventional specimen of English comedy in the third quarter of the eighteenth century. A good many of its so-called sentimental rouches-stilted dialogue, the requisitc happy ending abounding with good feelings and professions of gond intentions-can be found in comedies of every variety in the period. Further, a number of: these plays utilize, and not as parody, aspects of both laughing and sentimental comedy: Kelly's satire on false delicacy has been noted by more than one critic, none of whom has termed the play an antisentimental comedy $!^{21}$ As the early history of False Delicacy and The Good Natur'd Man demonstrates, two essentially different kinds of comedy-one laughing, the other sentimentalwere placed in deliberate and direct competition during the 1768 season. Kelly's was an enormous success. Its ridicule of false delicacy gave no offense. The Good Natur'd Man, on the other hand, received notably harsh treatment from the frst-night audience and from some of the reviewers not because it attacked sentimental comedy but because of the unacceptable low humor of the bailiffs' scene. Had Goldsmith not written this offending scenc, the intitial reception of his play would have been markedly different. When, three years later, he began work on a second comedy, the events of early 1768-Kelly's success and his own humiliation-were clear and bitter in Goldsmith's memory. She Stoops to Conquer was his cheerful revenge for the injuries done The Good Nalur'd Man.

\section{Notes}

1. See Ashley H. Thorndike, English Comedy (New York: Macmillan, 1929), ch. xvii; Arthur Sherbo, English Semimental Drama (East Lansirg: Mieligan State University Press, 1957); Robert D. Hutne, "Goldsunith and Sheridan and the Sripposed Revolution of 'Jaughing' against 'Sentimentol' Comedy," in Studies in Chonge and Revolution. ed. Puul Korshin (Menston, Yorks.: Scolar Press, 1972).

2. Robert B. Heilnan, "The Sentinentaliss of Goldsnith's Good Natured Man," in Studies for Willion A. Read, ed. Nathaniel M. Gaffee and Thomes A. Kirby (University, La.: Jouisiana State University Press, 1940), p. 237; Ricardo Qujnana, "Oliver Goldsmith, Ironist to the Georgians," in Eightecreth-Century Studies in Honor of Donald F. Hyde, ed. W. H. Bond (New York: Grolier Club, 1970, p. 309; Dobson's remark is from his "Introduction" 10 G. P. Baker's edition of The Good Natrer'd Man and She Strops to Conquer (Boston: D. C. Heath, 1903), p. xv; Roussentr's is in Goldsmith, The Criticnl Heriage (London: Routledge \& K. Paul, 1974), pp. 18.19. Apparently, Clara M. Kirk's Oliwer Goldsmith (New York: Twayne, 1967) is the single (and silent) exception to the received opinion of Goldsmith's intentions in his first comedy.

3. Collected Works of Oliver Goldsmith, ad. Arthur Friedminn (Oxford; Clarendon Press, 1966), V, 20, 52. All stubsequest references to Goldsmith's works are to this edition; volume and page nembers will be cited pirentheticnlly in the text.

4. "Asperts of Sentinentalism in Eiglvecuth-Ceniury Literature," in The Angartan Milien, ed. Henry Krighu Miller, es al. (Oxlord: Clarcudon Press, 1970). ]. 250.

5. P. 243. Heilman notes that W. F. Gallaway suggested this possibility in "'The 
Sentimentalism of Goldsmith," PMLA, 48 (1933), 1167-81. Heilman's article provides a useful survey of critical reactions to The Good Natur'd Matt.

6. "Goldsmith's Achievement as a Dranatist," UTQ, 34 (1965), 165. My italics. Quintana presents the same interpretation in "Oliver Goldsmith, Ironist to the Georgians," and in Oliver Goldsmith, A Georgian Study (New York and London: Macmillan, 1967), pp. 144-51.

7. "Oliver Goldsmith, Ironist to the Georgians," p. 310.

8. Ibid., p. 301.

9. Tbid., pp. 309]0.

10. 'Thornhill's speech is in IV, 79. Compare with Sir William Honeywood's "we must touch his weaknesses with a delicate hand. There are some faules so nearly allied to excellence, that we can scarce weed out the vice without eradicating the virtue" $(V, 20)$. The resemblance between the two speches is so close that if either had sone intrinsically parodic feature, the other would be equally parodic.

11. The Collected Letters of Oliver Goldsmith, ed. Katharine C. Balderston (Cambridge: Cambridge University Press, 1928), p. 61.

12. Pp. 242.43.

13. Sec The Gitisen of the World, Letters XXVI \&XVI1, in Collected Works, It, $108+120$.

14. Memoirs of Samuel Foote (London, 1805), I, 184. Cooke may have been anticipated by William Woodfall in 1773. In his review of She Stoops to Conquer in the Monthly Review, Woodfall says that Goldsunith, "recollecting that the comedies he had perused were very different from those which now prevailed ... imagined the Conic Muse had fled the lind. He determined to call her back, and employ her first in intro ducing the Good-Natured Man, and afterwards the present comedy" (quoted in Gold. smith, The Critical Heritage, p. 116). Cooke is more specifie in his clain that The Good Notur'd Matn was designed as an attack on sentimental comedy. In any event, both Cooke's and Woodfall's remirks were written after $A n$ Essay on the Theatre and She Stoops to Conquer.

15. Sec my article, "Sir Fretful Plagiary and Goldsmith's 'An Essay on the Theatre," in Quick Springs of Sense, ed. Larry S. Champion (Athens: University of Georgia Press, 1974), Pp. 116-17.

16. The London Stage, 1660-1800. Pt. 4: 1747-1776, ed. George W. Stone (Carbondale: Southern Illinois University Press, 1962).

17. As quoted in Works, V, 6. This notice appeared in the issue for 30 Ianuary-2 February. It was a review of the performances, not the printed versions, of the two plays. John Hawkesworth, in the Gentieman's Magazine for February 1768, compared the comedies along similar lines.

18. For an accotnt of the relationship between the two, see William Cooke's accoupt in the Exropean Magazine, 24 (1793), 17071, 422.

19. The Life of Oliter Goldsmith (London, 1837), II, 174.

20. As quoted in Works, $\mathrm{V}, 13, \mathrm{n}, 1$.

21. See Emest Bernbuum, The Drama of Sensibility (Boston \& London: 1915; tpt. Gloucester, Mass.: Peter Snith, 1958), pp. 225-27; Thorndike, p. 447; Sherbo. p. 147; Mark Schorer, "Hugh Kelly: His Place in the Sentimental School," PQ, 12 (1933), 389401; C. J. Rawson, "Some Remanks on Eighteenth-Century 'Delicacy,' with a Note on Hugh Kelly's False Delicacy (1768)," IEGP, 61 (1962), 10.13. 


\section{A House-Party at Stowe}

\section{BY W. S. L.EWIS}

When we think of English house-parties those at the turn of this century are the first we recall. On arrival at Paddington, Victoria, or Euston the guests were met by a deferential station-master; eager porters escorted them to the compartments reserved for the visitors going to Blank Hall. Their valets and maids hurried ahead with small but essential pieces of luggage such as a little pillow or Bath Oliver biscuits in a cut glass jar with a silver top on which were incised the owner's crest or initials beatutifully entwined. The masters and mistresses followed, warmly greeting fellow-guests or walking splendidly alone, "Effortless superiority" descended upon these happy few from their families who had built the greatest of empires; they were the richest and most self-assured people on earth, a quarter of which they governed. Max Beerbohm's little Hillary Maltby, nervously bound for his first grand house-party, tells how he "saw strolling on the platform many people, male and female, who looked as if they were going to Keeb Hall-all cool, ornate people who hadn't packed their own things and had reached Victoria in broughams. . . My porter was rather off-hand in his manner as he wheeled my things along to the 3:30. I asked severely if there were any compartments reseryed for people going to stay with the Duke of Hertfordshire. This worked an instant change in him. Having set me in one of those shrines, he seemed almost loth to accept a tip." After the happy few were comfortably installed they retired into their reading until the train stopped at their host's private station on the line. The less fortunate travellers peered respectlully through the windows as the house-party descended and got gaily into the waiting carriages and dogcarts or primitive motor-cars and were borne smartly away through a smiling country-side to the lodge gates, which were hastily swung open by an applecheeked maid or matron. The visitors proceeded on up the drive lined with ancient beches and oaks, and there at last, serene in its setting, was the great house and its disciplined staff waiting to look after the visitors. The houseparty had begun.

When and where, I wonder, is the first one in our literature? Not in Beowulf; not in Chaucer. What about the gathering at Belmont that Portia invited to join her after the trial? An anthology of house-parties, fictional and real, is a suggestion that some publisher may care to follow. It will certainly include, and may well begin with, Horace Walpole's account of his visit to

Reprinted with the kind permission of the Rowfant Club of Cleveland, Ohio. 
Stowe in July 1770 when Lord and Lady Temple entertained Princess Amelia there.

"The party," Walpole wrote to George Montagu (and to us), "passed off much beter than I expected. A Princess at the head of a very small set for five days together did not promise well. However, she was very good-humored, and easy, and dispensed with a large quantity of etiquette. Lady Temple is good-nature itself, my Lord was very civil, Lord Bessborough is made to suit all sorts of people, Lady Mary Coke respects royalty too much not to be very condescending, Lady Anne Howard and Mrs. Middleton filled up the drawingroom, or rather made it out, and I was determined to carry it off as well as I could, and happened to be in such good spirits, and took such care to avoid politics, that we laughed a great deal, and had not a cloud the whole time."

The guests lad no doubt been chosen by Princess Amelia, George the Third's unmarried aunt. An early portrait of her by Philjp Mercier shows a not at all pretty young woman in a conversation-piece with her brother, Frederick Prince of Wales, and her two sisters, the Princess Royal and Princess Caroline. They are grouped before their wing of Kensington Palace on a bland summer day. The Prince is crouching over and sawing away at a cello; the Princess Royal is sitting primly but purposefully at a clavichord; standing behind her is Princess Caroline who is nursing, rather than playing, a mandolin: a musical German family except for Princess Amelia, who apparently didn't play anything and who looks bored and cross. She was obviously a problem for the artist. He has seated her off to the right holding an open book in her lap with her left hand. Her right elbow is leaning on the back of her brother's chair, her right hand supports her head, which is evidently aching, and as she gazes at us heavily she might be asking, "Have you ever heard such a horrible noise?" In an effort to counterbalance this discordant figure, Mercier has planted some roses at the lower left, but they're no match for Princess Amelia. She is more amiable in Roubiliac's later bust and in Reynolds's sketch of the marriage of George III, but it is clear that she was very much her own mistress. There is a lot about her in Walpole's letters because she summoned him to play loo with her once or twice a week for twenty-six years. At the time of the house-party she was in her sixtieth year and was lively, shorttempered, and deaf. One night at her house while playing loo she badgered Walpole about politics, accused him unjustly of being a trimmer, and when she thought he was being disrespectful flew into a fury and berated him outrageously until he mollified her. Nevertheless, their friendship continued without resentment on either side, and eight years later she commanded him 
to meet her at Stowe on this housc-party although he had already declined the Temples' invitation to it.

The host, Richard Grenville, lst Earl Temple, also appears frequently in Walpole's letters. Allan Ramsay's portrait of him at the National Gallery in Melbourne shows him turusting his Gartered leg forward with a noble stare. He was the elder brother of George Grenville, the Prime Minister, and the brother-in-law of William Pitt, Lord Chatham, with buth of whow he quarrelled and was reconciled. "Temple," says the Dictionary of National Biography, "was a man of wealth and position, but without any great talents except for intrigue," an opinion from which Walpole, in whose Momoirs he makes an uncnviable showing, would not have dissented. Lady Temple, on the other hand, Walpole admired very much. He printed her locms at the Strawberry Hill Press with introductory verses of his own that begin "Long had been lost enchanting Sappho's Lyre," and end with the happy announcement that Lady Temple has found the missing lyre and played on it so harmoniously that to her modest surprise the lyre itself congratulates her. A year earlier, he wrote, at Lady Suffolk's request, verses on "Countess 'Temple Appointed Poet Laureate to the King of the Fairies," and we can't doubt that he was a most welcome guest at Stowe.

Lady Mary Coke, a daughter of the Duke of Argyll, was notorious for her addiction to royalty, from whom she received imaginary slights that moved her to loud complaint. She kept a journal in which she recorded everything she did and thought, whom she met and how they treated her. Mr. Walpole, who treated her with affectionate mock heroic gallantry, was a favorite except when she fancied he had been uncivil to her. She lived so close to Strawberry Hill that they could visit back and forth. He designed her library, shared her box at the opera, and dedicated lis Castle of Otranto to her in a sonnet that concludes, "For sure thy smiles are fame." Her account of the house-party at Stowe when joined to his is like a stereoscope where two slightly divergent views of the same object produce a startling and delightful depth. In her journal she records that on the day before going to Stowe she had a bad pain in her head and feared she must ask Princess Amelia to be excused from accompanying her, but the next morring she was up at 5:30 and reached the Princess's house near Ealing, two hours later. As H.R.H. was already dressed, they set out at once on their fifty-mile drive in order to get to Stowe in time for three o'clock dinner.

"The journey," Lady Mary tells us, "took just seven hours." It's too bad she didn't describe it. Did she and the Princess, and Lady Anne Howard and Mrs. Middleton all ride in the Princess's coach? No doult it was the last word in 
comfort, but it seems unlikely that four ladies in crinolines were cooped up together in it for seven hours. I think Lady Anne Howard and Mrs. Middieton were in a second coacl. There must also have been other vehicles for the servants and luggagc. Each lady of course had her maid, but how many servants did the Princess take? We hear later of the page who attended hes while she fished. He was a man, not a boy, who served as a botyguard and waited on her at table. Doubtless she also brought one or two footmen in toyal scarlet who stood behind her coach and assisted the page at table. With the coachmen and armed postilions (highwaymen were an ever-present danger), the party made a fine show rolling through the Buckinghamshite villages in clouds of dust with much cracking of whips, blowing of horns, barking of dogs, and scattering of chickens and geese on the highway. As the coaches heaved and swayed over the bad roads with the ever-present danger of being overturned the travellers must have longed for their journey's end. When at last they reached the lodge gates at Stowe, word was hurried ahead to the house to an nounce their approach. Lord and Lady Temple and Walpolc were sitting in the hall waiting for the news, and down the long flight of stone steps the three lame people hobbled to receive the royal party.

As three, when the Princess arrived, was also the dinner hour, the company doubtless dined at once without dressing. Aging travellers today would be exhausted by such a journey, which for Lady Mary was the modern equivalent of fying from New York to Honolulu, yet she tells us that after dinner everybody walked to the Roman arch Lord Tempie had erected to the Princess. "It began raining," Lady Mary reports, and "we play'd in the evening at faron," a long day without rest for a woman who could hardly hold her head up twentyfour hours earlier, but royalty had a healing effect upon Lady Mary.

As Lord Bessborough was not at the botton of the steps to receive the Princess he presumably hadn't yet arrived, but that evening he took the bank at pharoah and won all the money. Lady Mary's journal records that he had been with her and the Princess two nights earlier and that the Princess then proposed Lady Anne Howard to him for a wife, "and named the settlements." However, "Lord Bessborough said there was too much difference in their ages, but that if H.R.H. would accept of him the ages would agree better. The Princess laughed to such a degree she could hardly stand, but said "My good Lord, if I am Lady Bessborough I am afraid Lady Mary Coke will not cover her House with carpets to receive me,' 'Pardon me, Madanc; replied his Lordship, 'Your Royal Highness will keep Your rank, and I shal] agree that you keep Your fortune, desiring to be excused settling a jointure.' " Lord 
Bessborough became such a favorite with the Princess that she made him one of her executors.

Walpole's remark that Lady Anne Howard and Mrs. Middleton filled up or "made out" the drawing-room puts them in their places. Young Lady Anne, Lord Carlisle's daugliter, then twenty-six, was one of Princess Amelia's Ladiesin-Waiting, and Mrs. Middleton, Sir William Middleton's daughter, was a Bedchamber Woman. They are not featured in the accounts of the party, but they must lave been agreenble to suit the Princess. Ladies-in-Wailing received $f_{400}$ a year, Bedchamber Women $f_{2} 200$, wellearned perquisities for persons of quality waiting on royalty.

"We breakfasted," Walpole's letter continues, "at half an hour after nine; but the Princess did not appear till it wats finished." There was no question, apparently, of the other guests having breakfast in their rooms. After breakfast, Walpole goes on, .

we walked in the garden or drove about it in cabriolets, till it was time to dress: dined at three, which though properly proportioned to the smallness of the company to avoid ostentation, lasted a vast while, as the Princess eats and talks a great deal; then again into the garden till past seven, when we came in, drank tea and coffee, and played at pharoah till ten, when the Princess retired, and we went to supper, and before twelve to bed. You see there was great sameness and little vivacity in all this. It was a little broken by fishing, and going round the park one of the mornings.

Lady Mary's joutnal confirms Walpole's account, but adds triumphantly that when she was ordered by the Princess "to attend her to the great water to fish" she caught three-score in two hours: "two large carp and above twenty considerable perch; the rest small. The Princess catched about forty, but note so large as mine, to the great mortification of the page who attended her."

Although, Walpole tells Montagu, the days might seem much tilc same, "in reality," he wrote,

the number of buildings and variety of scenes in the garden made each day different from the rest: and my meditations on so historic a spot prevented my being tired. Every acre brings to one's mind some instance of parts or pedantry, of the taste or want of taste, of the ambition, or love of fame, or greatness, or miscarringes of those that have inhabited, decorated, planned or visited the place. Pope, Congreve, Vanbrugh, Kent, Gibbs, Lord Coblım, Lord Chesterfield . . . and Wilkes, the late Prince of Wales, the King of Denmark, Princess Amelie, and the proud 
monumonts of Lord Chatham's services, now enshrined there, then anathematized there, and now again commanding there, with the Temple of Friendship like the Temple of Janus, sometimes open to war, and sometimes shut up in factious cabals, all these images crowd upon one's memory and add visionary personages to the charming scenes, that are so enriched with fanes and temples, that the real prospects are little less than visions themselves.

I have two of Walpole's guides to Stowe and I like to think that he took with him the one in which he wrote several notes. This guide is Stowe, a Description of the Magnificent Hows and Gardens, 1768. Thanks to it we can picture the Princess in the State Bed-Chamber, which was roughly 50 by 25 by 18 feet, the chairs and hangings of crimson damask, the Corinthian pillars "finely carved and gilt," the ceilings "ormamented with the insignia of the Garter." The State Dressing-room was almost equally magnificent with rather better pictures; a very modern convenience was an adjacent bedroom for a servant. The State Gallery that led to these rooms was 70 feet long, had a painted ceiling, pier glasses, and tapestries with the triumphs of five Gods and Goddesses. The bedrooms and dressing-rooms of the other guests were on the same floor, literally one and two hundred yards away, for the house was 916 feet in length. In the gardens were arches, gateways, bridges, columns, monuments, pavillions, a Gothic Temple, the Fane of Pastoral Poetry, the Temple of Concord and Victory, the Temples of Venus, of Bacchus, of Ancient Virtue with statues of Lycurgus, Homer, Socrates, and Epaminondas, and of British Worthies with busts of Pope, Milton, Shakespeare, Newton, King Alfred, Queen Elizabeth, and many more. No visitor could ever have been more enchanted with the place than Horace Walpole. Later he wrote, "When by the aid of some historic vision and local circumstance I can romance myself into pleasure, I know nothing transports me so much."

His account of the house-party continues,

On Wednesday night a small Vauxhall was acted for tus at the grotto in the Elysian fields, which was illuminated with lamps, as were the thickets and two little barks on the lake. With a little exaggeration I could make you believe that nothing ever was so delightful. The idea was really pretty, but as my feelings have lost something of their romantic sensibility, I did not quite crjoy such an entertainment al fresco so much as I should have done twenty years ago. The evening was more than cool, and the destined spot anything but dry. There were not half lamps enough, and no music but an ancient militia-man who played 
cruelly on a squeaking tabor and pipe. As our procession descended the vast flight of steps into the garden, in which was assembled a crowd of people from Buckingham and the neighboring villages to see the Princess and the show, the moon shining very bright, I could not help laughing, as I surveyed our troop, which instead of tripping lightly to such an Arcadian entertainment, were hobbling down, by the balustrades, wrapped up in cloaks and great-coats for fear of catching cold. The Earl you know is bent double, the Countess very lame, I am a miserable waiker, and the Princess, though as strong as a Brunswic lion, makes no figure in going down fifty [actually, only thirty-one] stone stairs. Except Lady Ann-and by courtesy, Lady Mary, we were none of us young enough for a pastoral. We supped in the grotto, which is as proper to this climate, as a sta-coal fire would be in the dog-days at Tivoli.

Lady Mary agreed that "the night should have been a little warmer. Lord Temple," she adds, "sat by the Princess and talked to her all the time; Lady Temple, Lord Bessborough, and myself sang 'God save our Noble King,' etc. I was in hopes the people would have joined with us, but they were very silent. Mr. Walpole thought it rather too cold, and having some apprehension of the consequences, desired when we came back to the Honse a glass of Cherry Brandy by way of prevention." While the visit was in progress Lady Mary wrote that "Nobody can do the honours of their House with more ease and propriety than Lord and Lady Temple. The party is merrier than perhaps you would imagine. H.R.H. and Mr. Walpole are admirable company."

Walpole's letter concludes:

The chief entertainment of the week, at least what was so to the Princess, is an arch which Lord Temple has erected to her honour in the most enchanting of all picturesque scencs. It is inscribed on one side Anzeliate Sophiae Aug. and has a medallion of her on the other. It is placed on an eminence at the top of the Elysian fiedds, in a grove of otange trees. You come to it on a sudden, and are startled with delight on looking through it: you at once see through a glade the river winding at bottom; from which a thicket rises, arched over with trees, but opened, and discovering a hillock full of haycocks, beyond, which in front is the Palladian bridge, and again over that, a larger hill crowned with the castle. It is a tall landscape, framed by the arch, and the overbowering trees, and comprehending more beauties of light, sliade and buildings, than any picture of Albano I ever saw. 
Between the flattery and the prospect the Princess was really in Elysium: she visited her arch four and five times every day, and could not satiate herself with it. The statues of Apollo and the Muses stand on each side of the arch. One day she found in Apollo's hand [Lady Mary pointed it out to her? the following lines, which 1 had written for her and communicated to Lord Temple;

Tother day with a beautiful frown on her brow

To the rest of the gods said the Venus of Stow,

"What a fuss is here made with that arch just erected!

How okr temples are slighted, our altars neglected!

Since yon nymph has appear'd, we are noticed no more:

All resort to her shrine, all her presence adore.

And what's more provoking, before all our faces

Temple thither has drawn both the Muses and Graces."

'Keep your temper, dear child,' Phocbus cried with a smile,

'Nor this happy, this aniable festival spoil.

Can your shrine any longer with garlands be drest?

When a trute goddess reigos, all the false are supprest.'

The party broke up Saturday morning when the Princess and her little Court set out on their seven-hour return journey. Even Lady Mary Coke voted the visit a success although she had lost six and forty guineas to Lord Bessborough, but she was used to losing in spite of the carp bone (a palate) that she placed on the table to bring her luck and that one evening Princess A melia, shrieking with laughter, threw away. Walpole ended his letter to Montagu, "Good night, I am rejoiced to be once morc in the gay solitude of my own little Tempe." He was tired but pleased with his contribution to the success of the housc-party; it was no small feat for six aging people, three of whom were prima donnas, to spend five days together in the country with "not a cloud the whole time."

$\mathrm{He}$ and Lady Mary make us feel that we were actually present at the house-party, yet if we had becn there we should have had many surprises. We would have been prepared for the company's beautiful clothes and elaborate manners, but not for their short stature or their speech. Although no one is quite certain what they sounded like, it was apparently closer to a Down East Maine accent than to that of a modern Old Etonian. Some familiar words were pronounced so differently that we wouldn't have understood them at first, such as the word "spoil," which Walpole rhymed with "smile." We should have been struck by the tacit assumptions of every-day living that were so com- 
monplace to Lady Mary and Walpole they didn't think of mentioning them. Take the meals, for example. Walpole tells us when they had them, but unless we have secri cighteenth-century cookery books with engravings of the table set for each course we would not be prepared for the amount and variety of food that was heaped on the table in those beantiful silver salvers. Mrs. Elizabeth Moxon's English Housewifery (1769) gives sample menus for everyday consumption, such as "Dinner in Summer. First Course: Cod's Head or Salmon, Boiled Chickens, a fine pudding or roast lobster, Beans and Bacon, Stewed Breast of Veal. Second Course: Two young Turkeys or Ducklings, Stewed Apples, Custards, Jellies or Lemon Posset, Tarts, Preserved Damsins, green geese or young Rabbits." One of Mrs. Moxon's Summer Suppers offered Boiled Chicken, Preserved Oranges or Apricocks, Flummery, Asparagus, Lemon Posset, Roast Lobster, Stewed Apples, Almond Cheese Cakes, and Lamb. You told the footman behind your chair what you wanted, "a little of the lobster, please, a bit of green goose, and some flummery" as a starter. There was wine but no water. Mrs. Moxon's meals con firn Casanova's comment that "an English dinner is like eternity-it has no beginning and no end."

We who were born in the last century would have fewer surprises than younger travellers encountering for the first time the sounds, sights, and smells of a horse-drawn world, but all of us would share with the eighteenth-century people what Walpole called the "touches of nature" that link us to the men and women of every age. Examples of what he had in mind are Lady Mary's annoyance with Lord Temple for giving all his attention in the grotto to the princess and none to herself, her pleasure at catching more fish than the princess and in noting the page's "great mortification" that she had done so; other touches of nature are the Princess' joy in visiting her arch, Walpole's fear of catching cold in the dank grotto, and his satisfaction in having contributed so much to the success of the house-party.

He would be delighted to learn that we have invented the wonders that "will be done on the giant scale of a new hemisphere," such as flying and "spying-glasses to see all that is doing in China," and we would astonish him further with our railtoads, automobiles, deep-freezes, and telephones, climaxing our wonders with the landings on the moon. Finally, we could assure him that two centuries after the housc-party at Stowe we are turning to him more and more as a dependable chronicler of his time. After proving to him that grateful Posterity holds his life-work in the highest regard, we could return to the twentieth century pleasantly aware that he was savoring our encomiums in the gay solitude of his own little Tempe. 


\section{Harlequin Intrudes: William Cowper's Venture into the Satiric Mode}

By Lodwick Hartley

I wonder that a sportive thought should ever knock at the door of my intellects, and still more that it should gain admittance. It is as if harlequin should intrude himself into the gloomy chamber where a corpse is deposited in state.

Cowper to John Newton, 12 July 1780.

In the last quarter of the eighteenth century Methodism was on the rise and classical satire was waning. Between these two phenomena little logical nexus may be apparent. But by an umisual set of circumstances, William Cowper attempted an amusing merging of the religious movement and the literary tradition in a minor mock-heroic poem that would not have been of real importance had it not ultimately launched him into a major literary effort destined to make him the most popular English poet of the last decades of his own century, as well as the first decades of the next. ${ }^{2}$ In fact, it is an interesting possibility that had the Reverend Martin Madan not made a singular exegetical misstep, Cowper might have come down to posterity as a far less important poet than he finally became.

By his own admission, Cowper had been a poet since he at fourteen turned a piece of Tibullus into English verse at Westminster School, where he later was able to vie in poctic trifles with such literary "geniuses" (in Boswell's term) as Bonnell Thorton, George Colman the Elder, and Robert Lloyd. A generation later, in 1779, he had achieved some notice as co-author of the Olney Hymns with his close friend, the Reverend John Newton, converted master of a slaving vessel and now a leading Evangelical divine. But in his more than a decade of retirement at Olney after his recovery from his mental breakdown of 1763 he was virtually unknown except by his Evangelical friends; and his real reputation lay ahead of him.

There is some irony in the fact that Cowper's start on the most important phase of his career came through his making Martin Madan the butt of a satire; for Madan was Cowper's cousin and the son of his truch beloved aunt, formerly the beautiful Judith Cowper with whom Pope had corresponded. Six years older than Cowper, Madan had entered Westminster in 1742, the year after Cowper did. In the next year he went to Christ Church, Oxford, where 
he stayed until 1746. In 1748 he was admitted to the Bar, After living the life of a man about town in London for several years, he heard a sermon by John Wesley that converted him to Methodism. As a result, he took orders. Though his age differential may have prevented close intimacy with the poet at Westminster, he is known to have stood by Cowper during his serious mental illness in London in $1763 .^{2}$ He was widely regarded as a man of genuine sensitivity and intelligence. Unfortunately, however, as chaplain at the Lock Hospital in London his observation of the terrible effects of venereal discases in the fallen women there caused his humanitarianism to triumph over his judgment. As a result, he was led to write two volumes (and later a third) of a work called Thelyphthora; or a Treatise on Female Ruin, in a section of which he proposed polygany as a solution for the problem of prostitution in England, elaborately justifying his proposal witly refcrences from the Pentateuch. The volumes that appeared on 31 May 1780, bore the imprint of the famous bookseller, James Dodsley.

The work had not come out unexpectedly, Madan's patroness in Methodism, the Countess of Huntingdon, knew about the projected publication in advance, as also did John Newton; and both did their best to dissuade Madan from his folly. Though, as Hugh Fausset has pointed out, Newton hat used the same sort of Old Testament justification for his own conception of a vengeful God, he was aghast that Madan should have applied it so adeptly for such a scandalous purpose. Cowper had heard from Newton about the coming event, but his reaction had been that of amusement rather than of indignation or horror. Five days after the publication of the book, Cowper cnclosed in a letter to Newton a little poem which he called "Anti-Thelyphthora" (later renamed "The Doves") in the opening stanza of which (later suppressed) he referred to the "much lamented day," ominously forecast like a present-day tropical hurricane, on which Madan's treatise issued forth like "a tempest fear'd." ${ }^{\prime 3}$ The poem held up the mating of doves as an argument against the wisdom of men who advocate polygany and ends with a postseript flattering Newton and his wife as exemplars of monogamous bliss in the true Evangelical manner.

A tempest had, indeed, been stirred in an Evangelical teapot and many people were drawn into it, with published answers and vilifications in various literary shapes and forms. In an impulse of more indignation than common sense, Newton suggested to Cowper that he write a reasoned refutation. The poet, understanding himsele far better than his friend did, declined, pleading that both mental and physical fragility made him incapable of such an under- 
taking. (Cowper had not yet read the book and was not to do so until April of the next year.)

If Cowper had pangs of conscience alsout turning down the request of suci a close friend and mentor as Newton, he felt that he had been taken off the hook when word came to him on October that the Reverend Samuel Badcock had dealt properly with Madan in the current Monthly Review. The Review, which was Cowper's favorite periodical, had been founded in 1749 by Ralph Griffechs, who remained its editor until 1803. Such was the liberalism of the magazine in politics and in rcligion that the Critical Review, virtually under the editorship of Smollett, had to be set up as a counter-agent. The Critical's patronage was 'Tory and Church, whereas the Monthly's was Whig and Evangelical. (It will not be forgotten that Samuel Johnson told George 111 in their famous interview that the authors of the Monlhly were "enemies of the Church.") Badcock had been highly influential in changing the periodical from a collection of abstracts of books to a truly critical journal. Moreover, he was its leading theological and literary critic. Thus a refutation of Madan from him wals a highly significant counter-blow.

In fact, the performance was so pleasing to Cowper that, when he got his copy of the magazine, in a mood of buoyancy he wrote to William Unwin: "I have read the Review; it is learned and wise, / Clean, candid, and witty,Thelyphthora dies." The fact that the postscript was in couplet form suggests that, even though subconsciously, Cowper was working up to a light poetical attack on a work that had just been successfully countered in a reasoned argument-thus whipping a dead horse that he had been incapable of bridling when alive!

At any rate, in November Cowper wrote the little mock-heroic piece that he called Anti-Thelyphthora: A Tale in Verse and posted it off to London, where Newton, having approved it (though apparently not without misgivings), took it quietly to his publisher, Joseph Johnson, for strictly anonymous publication-in the traditional eighteenth-century manner. The little quarto pamphlet came out in December, 1780, though it was dated 1781.

As a classical scholar Cowper had to yield to none of his contemporaries. His knowledge of Homer, based on a love kindled at Westminster, ultimately led to the most accurate poetic translation of the lliad and the Odyssey yet achieved. He, indeed, could look with contempt upon Pope for not knowing more about the Greek of the original Homer-as well as on Dr. Johnson for not detecting the fact. He also had a sound knowledge of Virgil, whose influence, especially in The Tash, is easily seen. But it was Horace with whom he was able to identify most completely. Though their lives and their subject 
matter were in many ways quite different, they shared an enjoyment of the simple life and the contemplative habit of looking out on the world from a place of retirement: one a Sabine farm and the other the village of Olney in Buckinghamshire. As a writer of light verse (often for therapeutic purposes) in his early days, Cowper was more likely to be influenced by Horace's odes than by his satires. So, unlike Pope, he had not been drawn early to the satirical mode. "Imitations" he could manage when he chose. But he was not frequently attracted to the burlesque. Even an amusing little piece like "The Colubriad" belongs more to the numerous progeny of "-iads" in title than otherwise."

Yct, adopting as his scheme for Anti-Thelyphthora a knightly combat burlesquing the general Spenserian manner of allegory (though not the archaic language) he was taking the easy way out-in short, that of the cliché. But rarely did Cowper depend on a structural device, which he usually honored in the breach rather than in the observance, for the accomplishment of his purpose. And the choice may have been rather one of unpretentiousness than of lack of imagination.

The two combatants of the poem are easily identified: Sir Airy del Castro is Martin Madan and Sir Marmadan is Samuel Badcock. These go to the jousting over a "matchless dame," Hypothesis, born in Fairyland of the "Inchantress, Fancy"--apparently of immaculate conception since the genealogy, unlike those of Spenser and Milton, ends at this point. Sir Airy (he of insubstantial reasoning) has wooed the lady by meandering streams (of reasoning and exegesis, we are to assume), weaving in haste out of Howers (of rhetoric) wreaths for her brow and girdles for her waist and amorously addressing her as "Posy" (again with the suggestion of a collection of rhetorical flowers). Such has been Posy's influence that she has had no difficulty in seducing him from his "oaths of knighthood" (clerical vows) and making him forgetful of the "toils of war" (the Church Militant as the Methodists conceived it).

Sir Airy, of course, had not been the only knight seduced by Hypothesis. There had been those, for example, who had been misled by Bishop Berkeley's philosophy of immaterialism-

That forms material, whatso'er we dream Are not at all, or are not what they seem: That substances and modes of ev'ry kind, Are mere impressions on the passive mind; And he that splits his cranium, breaks at most A fancied head against a fancied post. 
(Dr. Johnson had presumably kicked a real stone with a real toe in attempted disproof.)

Other misguided ones had been deluded into the false reasoning of Thomas Burnet's The Sacred Theory of Earth, or Telluris Theoria Sacra (1681), contending that the

carth, ere sin had drown'd it all,

Was smooth and even as an iv'ry ball;

That all the various beauties we survey,

Hills, valleys, rivers, and the boundless sea,

Are but departures from the first design,

Effects of punishment and wrath divine.

(John Calvin, it is interesting to note, had been one of Burnet's prime opponents in rejecting this theory; so Cowper's position was well within the Evangelical "party line.")

In all, many had been trained by Hypothesis in the Daedalian art of making labyrinths, but none had indulged in such wildness as Sir Airy in contending

That wedlock is not so rig'rous as suppos'd,

But man within a wider pale inclos'd,

May rove at will, where appetite slaall lead,

Free as the lordly bull that ranges o'er the mead.

In the process, man, instead of being freed, stands actually to be made a slave, while the wedding ring becomes a bauble, and the priest a knave.

Then on a fair autumnal day-described in a few excellent lines that presage Cowper's nature descriptions in The Task-Sir Airy takes Hypothesis as his bride-that is, by publishing his notorious book. The "dank and drizzling" fog that the bride calls up now causes "the sex" to be scized with fear lest the marriage bond should forever lose its binding power:

The bride, while yet her bride's attire is on,

Shall mourn her absent lord, for he is gone,

Satiate of her, and weary of the same,

To distant wilds in quest of other game.

But if British nymphs tremble, not so the Circassian fair; thus "Seraglios sing, and harams [sic] dance for joy."

Fortunately, however, there is a knight who is true to his vows to succor maidens in distress: "Knight of the silver moon [the chaste Diana] Sir Marmadan." Since his lance is extracted from the famed cedars of Lebanon (symbolizing sound Old Testament learning capable of refuting false scriptural 
argument), he is impervious to the enchantment of Hypothesis. Striking his lance thrice upon his saddle bow and thus drawing three sparks (with symbolism that is transparent enough), Sir Marmadan dispels the magic mist, exposes the "unseemly pair," and issues his challenge to the recreant knight. The "insidious witch," not to be outdone, springs up on the saddle behind Sir Airy to encourage him and urge him on. But the fight is bricf. Like Phineas, son of Eleazar, who in Samuel 25:6-9 (with pointed relevance to Samuel Badcock) speared the Israelite and his Midianite harlot, thus turning away the plague from his people, Sir Marmadan, after a short speech of denunciation, transfixes Sir Airy and Hypothesis at a single blow, thus saving the "British fair" from another plague. In consequence (now with Miltonic echoes),
The Fauns and Satyrs, a lascivious race,
Shriek'd at the sight and, conscious, fled the place:
And Hymen, trimming his dim torch anew,
His snowy mantle o'er his shoulders threw.

No one can argue that the poem is a classic of mock-heroic verse; but it is by no means an embarrassing performance, and it can still be read with pleasure by those who know a little of the background.

The Critical Reviez noted the Spenserian indebtedness and remarked that the allegory was "invested and supported with a tolerable spirit of poetry."7 But a "Brother Reviewer" of Sir Marmadan in the Monthly Review rose better to the occasion in a witty piece that deserves at least partial quotation:

The heroes of this little tale are-Reader, pull off thy hat - the Rev. Martin Madan, and-put on thy hat again-the Monthly Reviewer! These redoubted champions enter the lists in the quality of knights; each having his mistress, but neither of them provided with an esquire to gird on his buckler, lead forth his Rosinante, or hold the stirnup. This is a sad defect in a chivalrous poem; and the author might as well have left the knight's horse, as his esquire at home. And, moreover, we think it is a slight on 'squire Dodsley and 'squire Griffths to bave been totally omitted in the Tale of their own knights; when it is evident that they attended them to the field, and at least held the stirrup, if they did not draw the sword.

But let us be serious-though it is impossible to keep [from] smiling at the idea of a Reviewer's becoming a knight-unless a Knight of the Post, in the present dearth of letrers!-We must do our poet the justice to acknowledge, that his tale is the offspring of an elegant fancy and 
we are obliged to him for the compliment he hath paid our theological associate....

The review continues with a brief synopsis, concluding with a comment on the climax of the battle between the Knight of the Airy-Castle and the Knight of the Silver Moon thus:

"Transfix'd them:"-i.e. Sir Airy and Dame Hypo:-spitted like two sparrows!-By Dian's quiver-an excellent stroke!- ${ }^{8}$

Also reviewed are such pertinent works as $A$ Poetical Epistle to the Reo. Mr. Madan on the Publication of his Thelyphthora. By a Nymph of the King's Place; Marriage and its Vows Defended. By a Female Christian, but no Methodist; A Poem inscribed to $M r . M-d-n$; The Political Priest; or, Propagation with a Vengeancel A Satire by a Married Woman, with a Prologue, by a Married Man; and a Preface by an Old Batchelor. The whole addressed to the Fcmale Sex, and dedicated (without permission) to a certain Rev. Polygamist.

Evidence that Cowper continued to enjoy the merriment of his mock-heroic bit may be found in the fact that sometime between October and December he posted oft to the Gentleman's Magazine a doggerel quatrain, "Impromptu on Reading the Chapter on Polygamy, in Mr. Mzdan's Thelyphthora," published unsigned in the December issue:

If John marries Mary, and Mary alone,

'Tis a very good match between Mary and John.

But if John weds a score, oh, what claws and

what scratches!

It can't be a match-' tis a bundle of matches."

(Jolnn and Mary were the Newtons.) Yet amid the fun Cowper also had had grave misgivings about his having been entirely flippant in a matter for which Newton had requested a sober treatment. On an entirely different level he had developed the hope that, since Joseph Johnson had been receptive to the publication of his little jeu d'esprit, he might consider somedhing entirely serious on the same subject. So with the encouragement of his companion, Mrs. Unwin, Cowper had in November begun his first "moral satire" (though this was not actually his designation) called The Progress of Error. When he wrote Newton on 21 December to tefl him about it, he took pains to assure his friend that he was not again employing the mock-lieroic mode: "Don't be alarmed. I ride Pegasus with a curb. He will never run away with me again."

The connection of the new serious poem with the comic little one is 
important. Again, there is at the outset a Spenserian echo: "foule Errour" of the Faerie Queene I.i, becomes "the serpent error." And the whole piece is about how crror beginning in the current cult of pleasure progresses to error in "scripture warp'd from its intent," with its evil effect inevitably proceeding from clergy to the flock. Veilcd references to Madan can be found throughout. But Cowper was not finally willing to associate himself with an attack on his cousin. Thus a passage beginning "Curs'd Thelyphthora, \&c" was first changed to "Abhorr'd Thelyplithora, \&c" (because, says Thornas Wright, "curs'd" shocked Newton by reminding him of his early swearing as a sailor), and finally the entire passage was dropped, with the substitution of a satirical "character" of Lord Chesterfield." Near the end of the poem, Cowper asserts "I am no preacher." But any reader observing his attacks on such favorite subjects of the rcvivalist preacher as card playing, dancing, and music on the Sabbath will likely feel that the whole poem is more sermon than satire.

Having by this time established a daily scliedule for writing verse, Cowper proceeded to turn out Truth, with typical Evangelical sermonizing on Grace versus Works and with the basic argument that Pride is the chief obstacle to Truth.

At this point he began to have fears that, if the two poems just completed introduced the volume of verse that he envisioned, nobody might be induced to read it." So he changed his tack and wrote what he hoped might be a "decoy"-a satire called Table Talk dealing with such current topics as problems of government and leadership in a period when England was beset by numerous enemies and when the loss of her American empirc was impending. $\mathrm{He}$ also managed to include a consideration of the functions of the poet in such times, modestly denying for himself the ability to assume the lofty traditional role of vates. The poem itself he described accurately as "a medley of many things," thereby suggesting that he was conforming to a typical Augustan definition of satire (satura). For the dialogue form he needed no other models than the quite familiar ones of Horace or Pope. But he turned rather to his old schoolfellow of Westminster days, Charles Churchill, who in The Farcuell had written a meandering dialogue between P. (Poet) and F. (Friend), beginning with P.'s announcement of his resolution to leave England for India. F.'s question "Are there not knaves and fools enough at home?" leads to a fairly lengthy answer that finally involves a discussion of ideal patriotism and concludes with the well-known line, "With all her faults, she [England] is my country still." (This line Cowper was to save for a masterful paraphrase in The Task). For his treatment of the "Patriot King," Cowper drew even 
more fully on Gotham, and there are echoes from such other Churchillian pieces as Night and The Apology.

The poem, indeed, offers a welcome change from the preceding two, and it is the most Churchillian of all the satires, not only in material but also in the poetry. Cowper did not disguise his feeling that Pope's infuence, due to his mastery of the highly polished couplet, had made poetry "a mere mechanic art" or his dissatisfaction with the "creamy smoothness" that he thought characterized most mid-century verse. Rather was he inclined to admire the vigor and manliness, even rudeness, of Churchill's heroic couplets and hexameters, as well as the way Churchill struck his lyre "in a careless mood." It is then no wonder that Cowper's couplet in his satires is rather a modification of Churchill's than an imitation of Pope's. Cowper caps his general indebtedness by including a fine tribute (11. 670-9) to his model.

Had he continued in the same vein as that of Table Talk, he might have been considered along with Churchill as a respectable representarive of a transitional period in the history of satire in the century. Unfortunately, however, for three more poems he continued doggedly on the assumption that he could write a new kind of satire that would please his Evangelical friends and contribute to the spiritual salvation of the world while escaping the aesthetic blight of religious propaganda. Expostulation is, therefore, a lugubrious jeremiad that has justly come to be regarded as the worst of the moral satires. Hope, only a little better, is a sermon denying all salvation except the Evangelical kind. The third, Charity, it is true, is less depressing and more important because it deals, among other things with such current humanitarian issucs of the century as the freeing of slaves and the proper use of philanthropy. For our purposes, an even more interesting thing about it is that it contains Cowper's formal rejection of Augustan satire. The satire of Pope and Swift: he suggests, had too often been mad, cruel, and self-serving, the satirist railing "to gratify his spleen" and hiding his own offences behind a magisterial air, anonymity, and "interjected dashes," while he stripped others clean. In summary, Cowper declares-

\section{All zeal for a rcform, that gives offence \\ To peace and charity, is mere pretence.}

Though even the dullest of the moralizing and sermonizing poems contain passages of genuine poetic excelience-perceptive and humorous comments on manners and society and skillful "characters"-Cowper's experimentation in an attempt to combine Evangelicalism and formal satire had hardly been successful. He did not have to wait for the reports on sales of the 1782 volume 
to recognize the fact. Evidence that he did so much earlier lies in his now quietly and unobtrusively beginning to free himself in his next two poems, also intended like the preceding ones for the 1782 collection, from the hobbling infuence of such well-wishing Evangelical friends as Mrs. Unwin and Newton. In the first, Conversation, he returns significantly to a subject that while he was a youth in London he had treated in a Connoisseur cssay; whereas the second, Retirement, is a poem of praise for the country not because (as usually had been the circumstance) it is not life in the city but because it is life among birds, trees, and flowers. No one would argue that at this point the poet had got rid of the shackles of his Evangelical influences-as indeed he never did entirely. But he was learning that in order to speak out in his finest voice he had to write not what others wished him to write but rather what his own feelings, sensitivity, and conscience dictatcd.

This lesson learned, he was ready at the instigation of a new friend, Lady Austen, to admit Harlequin for an uninhibited ride with a certain London draper named John Gilpin and also to take the same lady's suggestion as to how to embark on his finest poetic venture, The Tash, which came out in 1785 . This classic in the art of digression invoked the mock-heroic once again for the beginning, mildly parodying the Aeneid and Paradise Lost. But it quickly moved to another kind of poetry already initiated in Retirement, praising the simple life of the country and the healing and the plcasure to be found in the presence of rature. Eventually it included such a wide variety of matcrials that it created, as Wordsworth nuted, a new genre which is a "composite order" of the idyllic, the satiric, and the didactic." The heroic couplet, now regarded by the poet as the hackneyed instrument of Augustan satire, was moreover, thrown overboard for blank verse.

Unfortunately, some evidence of the old preaching tendency remained in The Task and the death's-head was not always absent from the feast. Thus Harlequin was by no means enshrined. But though the effects of his early "intrusion" may have for a time seemed to be swallowed up in the gloomy chamber of the moral satires, they had actually set in motion a creative impulse that in the short period between the inception of Anti-Thelyphthora in October, 1780, and the completion of Retirement in October, 1781, eventually led the poet to his best achievement.

\section{Notes}

1. See iny note, "Cowper and the Polygamous Parson," MLQ, 16 (1955), 137-41, which provides part of the material of this essay. Quotations are from Anti-Thelyphthora. A Tale, in Verse (London, 1781).

2. Charles Ryskanp, Willin Cowper of the Inner Temple, Esq. (Cambridge, 1959), 
Pp. $158-59$. 195.

3. Thomas Wright, Correspondence of William Cowper (London, 1904), 1, 172-73,

4. Wright, $I, 215$.

5. See Wright, III, 81-84, where the letter is included among those of 1786 . Southey had originally made the same mistake, which he corrected through a note, overlooked by Wright, in the index to the letters. Badcork's review actually appeared in two parts in October and November: Momhly Review, 63 (1780), 273-87, 31 1-19. Cowper's letter thus must have been written either in October when the first part appearcd or in early November when he had reat both parts. Sce also $M L Q, 16$ (1955), 139.

6. Richnond P. Dond, Einglish Burlesque Poetry (Cambridge, Mass., 1932), p. 124.

7. Critical Review, 51 (1781), 74 .

8. Monthly Review, 64 (1781), 229 .

9. Gentleman's Magazine, $50(1780), 582$.

10. Wright, I, 248-49. Nevertheless, on the sume diy Cowper wrote Joseph Johnson cnclosing four lines to be added to Anti-Thelyphthora in the event that i second edition was called for. None was, and the pocm fell into obscurity. Thus its anonymity was prescrved until Robert Southey discovered a copy of the original edition and included it in his edition of Cowper's Works in 1835. The four lines are quoted by J. C. Bailey, The Poems of William Coruper (London, 1906), P. 675.

11. Wright, $\mathbf{I}, 270$.

12. Sec Worhs, ed. Southey, I, 194.

13. See David Boyd, "Satire and the Pastulal in The Task," PLL, 10 (1974), 363-77. 


\section{The Contributions of Abel Boyer as Whig Journalist and Writer of the Protestant Post-Boy, 1711-1712}

\section{By Henry L. SNyder}

Abel Boyer was one of the most prolific and important of the early eighteenth-century journalists working in England. Yet he receives only bare mention in treatises dealing with the press of the period. Moreover, no thoroughgoing effort has been made to identify alt his writings. Consequently the importance of his work is not fully recognized. For some he is remernbered as the editor of a pioneer French-English dictionary that went through forty-one editions between 1702 and 1841 . By others he is remembered as a translator and editor. He was one of those Huguenot writers whose enforced exile brought them to the Dutch Republic and to England, where they became important purveyors of French literature in England and English literature into French. ${ }^{1}$ For historians Boyer is best remembered as one of the most reliable and knowledgeable of the contemporary historians of the reign of Queen Anne. In his History of the Reign of Queen Anne Digested into Annals he published eleven volumes, annually from 1703 to 1713 . These volumes contain useful summaries of Continental events, particularly the War of the Spanish Succession, and a good account of domestic affairs. They are notable as one of the first publications to contain summaries of Parliamentary debates. The Annals gained a new life and still greater circulation when they were re-formed into his History of Qucen Amme, which appeared in $1722 .{ }^{2}$ Together with Bishop Burnet's History of His Oun Time (1724-1734) and John Oldmixon's History of the Stuarts (1730-1735) it remains one of the most detailed and durable accounts of carly eighteenth-century England, tegularly cited by scholars down to the present time.

In spite of the fame and value of these other works, Boyer's greatest achievement may well have been his Political State of Great Britain, a monthiy he edited from January 1711 until his death in 1729. It carried on the summaries of Parliamentary debates begun in his Annals, now providing them for the public within a month of the event. Until the inauguration of the London Magazine in 1732 and of the still later publications devoted exclusively to debates which commence in the 1740 's, it was the only publication to bring a regular account of the debates in Parliament to the public. ${ }^{8}$ Although the Political State is a great quarry for scholars, not least for its record of contem- 
porary polemical literature, which Boyer regularly summarized or abstracted, it has yet to be carefully examined for the light it throws on Boyer himself.

Even the categories of publications discussed so far do not exhaust Boyer's bibliography. He was also active as a newswriter of both newspapers and unpublished newsletters, and it is to some aspects of his journalistic career that we will now direct our attention. Boyer's role as a translator and disseminator of French literature and culture in England las already been alluded to. What is not so well known is the similar rolc he played in the dissemination of news. For many years of his career he was closely allied with purveyors of news both in England and on the continent. The Huguenots because of their dispersal in exile formed an important if informal international connection that proved useful for banking, for trade, and for the news and book trade. We know that at the end of Anne's reign, and probably earlier, Boyer was writing a newsletter in French that carne out weekly. It is clear from the work of Graham Gibbs and others that there was a small circle of journalists or newswriters in England who were employed in supplying newsletters to foreign courts and newswriters on the Continent. ${ }^{\text {" }}$ Boyer must have been one of these. He was probably a correspondent to the eminent Guillaume de Lamberty, another Fuguenot resident at Amsterdam, whose newswritings were collected for the period $1700-1718$ and published in fourteen volumes from 1735 to 1740 and now form one of our most important sources for the period.

Apparently there was an international circle of journalists exchanging newsletters and supplying their collaborators in other countries with news from their own. ${ }^{0}$ This is how each in turn acquired materials for his own domestic productions. It was from these sources that Boyer obtained the excellent reports on continental affairs that filled his Annals. The linkage with the foreign envoys is not so clear, but the fact that his newsletter was written in French is a good indication that it was sent abroad. Boyer made good use of these connections from soon after his arrival in England. The close similarity of material in the dispatches ostensibjy written by Friedrich Bonet, the Prussian resident in London, to the King of Prussia, Lamberty's Memoires de la derniere revolution d'Angleterre (2 vols., The Hague, 1702), and Boyer's History of William III ( 3 vols., London, 1702), and the fact that some information appears in these three places, one (Bonet) unpublished, and nowhere else, is cogent evidence of collaboration if not a pooling of information. Further evidence of this collaboration would require a detailed examination of the unpublished commercial newsietters and newspapers of several countries and is beyond the scope of this paper. Moreover, although the materials themselves are very scarce now, they do exist, and the study must be made. ${ }^{8}$ 
One final dimension of Boyer's career will occupy the balance of this paper: Boyer's work as a newspaper writer has received very little attention and for this reason can have some special interest for us. Moreover, it reveals most fully another element in his writings, his zealous Whig partisarship. Francis Espinasse in the Dictionary of National Biography makes reference to Boyer's "zeal for whig principles" but gives no evidence of his partisanship. Boyer himself described his monthly Political State as "an impartial account of the most material occurrences, ecclesiastical, civil and military." The principal newspaper with which he was known to be associated was the Post-Boy. This long-lived periodical, which began in 1695 and continued until at least 1735, was produced for many years by Abel Roper, a London bookseller and entrepreneur with pronounced Tory sympathies. Boyer was hired by Roper in 1705 to translate continental news from foreign newspapers for the Post-Boy, an indication of his connection with the news purveyors on the continent. Prior to that time Roper had published Boyer's History of William III as well as the Annals so that their association extended back to at least the beginning of Anne's reign. After a quarrel with Roper, Boyer quit him in August 1709. He then commenced his own newspaper, the True Post-Boy', which ran as a rival to Roper's until Boyer ceased publication in 1710. After Robert Harley engincered Lord Treasurer Godolphin's dismissal in July 1710 and assumed the real leadership of the ministry, Boyer offered his services to Harley as writer for the Gaatte, hoping to displace Richard Steele as the editor of this officially supported government newspaper. Boyer was disappointed in his endeavour though indeed Steele was subsequently removed because of his ardent Whig views. As I have shown elsewhere, Boyer wrote two very well-received apologias for the ministerial revolution of 1710 which brought the Tories to power. They were sent to Harley as a testimonial of Boyer's ability and support and as an inducement for Harley to give Boyer the Gazette post." Thereafter the record shows only that Boyer began the Political State in January 1711 and that he devoted the remaining years of the reign to this monthly and the Annals. Only two other works have been ascribed to Boyer's pen for the 1711-1714 period. ${ }^{10}$

If Boyer was indeed a zealous Whig, to what extent did his political views show in the years when the Whigs were under so severe attack in the last part of Anne's reign? His Accotint of the State and Progress of the Present Negotiation of Peare (1711) is a single example. Indeed, the offer to Harley, the authorship of the two Harleyitc tracts, and the association with Roper all point to a distinctly Tory sympathy. New evidence now shows clearly that though he had offered assistance to Harley as early as $1704^{11}$ (significantly in relation 
to his fellow Huguenots and his connections in the Dutch republic) Harley never seems to have responded positively. His estrangement from the Tory Roper may have given Boyer further encouragement to turn to the Whigs. Certainly their support for the dissenters and the French Huguenots, whom the Tories treated so suspiciously, would have made it more likely for him to have been associated with the Whigs rather than the Tories. And this was the case.

In reading through the issues of the Protestant Post-Boy, a strong Whig, pro-Marlborough publication, which appeared semi-weekly from 4 September 1711 until 12 July 1712 , I was struck by certain expressions and references that suggested they might have come from Abel Boyer, a possibility confirmed by a comparison with the Political State. A study of contemporary Whig tracts gave further indication that Boyer might have had a hand in some of these as well, and that he might have been one of the several writers recruited by the de facto Whig press lord, Arthur Maynwaring. Boycr was apparently most resentful of his former employer and the treatment he had received from him. The frequent disparaging references to Abel in the Protestant Post-Boy were one clue to Boyer's participation. For the same reason the tract $\mathrm{High} \mathrm{Charch}$ Aphorisms, Writun by Those Twin-Brothers in Scandal, the Author of the Examiner and Modest Abel (1711), made up largely of quotations from the Medley, written by Maynwaring and Oldmixon, juxtaposed against other quotations from Swifl's Examiner and Roper's Post-Boy, is suggestive of Boyer. ${ }^{12}$ To be sure, Roper's cooperation with the Tory ministry and his willingness to insert material from Henry St. John, the Tory Secretary of State, made Roper a likely target from any dedicated Whig writer. But there is a special venom in the attacks by Boyer, apparently because of their former relationship. Swift also secms to have been another bate noire of Boyer, and the feeling was reciprocated. The confirmation of Boyer's authorship of the Protestant Post-Boy appeared only recently, noticed by a scholar in one of the later volumes of the Political State. ${ }^{13}$ In the issue for February 1727 Boyer admits authorship and names the obscure Philip Horneck, the ne'er-do-well son of a respected German clergyman who settled in England during the Restoration period, as his collaborator. With Boyer's authorship now corroborated we may turn to the pages of his paper to see what they reveal of Boyer's activities in this period.

The Protestant Post-Boy should be read in conjunction with the Political State and the Annals. They betray many similarities, and a carcful examjnation provides further evidence for Boyer's Whig zeal at this time in $h$ is career and also further evidence of his publications. The tenth volume of the 
Annals, for example, which appeared in 1712 and covered the regnal year March 1711 to March 1712, bears the most partisan introduction of any of the eleven volumes Boyer wrote in this serjes. It is dedicated to Thomas, Earl of Wharton, certainly the most aggressive, notorious, and partisan of the Whig Junto, the disciplined core of the Whig party. In it Boyer upholds the Whig borough-mongerer as a great patriot and castigates the Tory ministry and its reversals of Whig policies in a long ironic harangue. He takes particular care to defend the disgraced Captain-General, John, Duke of Marlborough, who was "not only flagitiously libell'd by abandon'd hire]ings [Roper and Swift], but ungratefully-attack'd, upon frivolous and false suggestions, by those very men who originally owe their present preferences to his former favour [a particular slight on St. John]." In so doing he follows the party line laid down by Maynwaring and adopted by his seconds and associates, Oldmixon, Steele, Hare, and others. A further reading of the same volume reveals Boyer as the writer of a tract on the South Sea trade (p. 230) often ascribed to Defoe, most recently by John Robert Moore. ${ }^{14}$ One finds many references to the Post-Boy, several to Swift, "a Court Tantivy," (p. 230), and references to a number of important Whig tracts that one finds again in the Protestant PoskBoy. The frequency of their citation, the fact that all of them cars be identified with Arthur Maynwaring, either written, edited, or commissioned by hirn, lends further credence to the belief that there was some connection between the wo. Just as Swift, rebuffed by the Whigs, turned to the Tories, ${ }^{10}$ so Boyer, rebuffed by the Tories, or more particularly Harley, turned to the Whigs. It should also be noted that Boyer identified both Hare and Walpole as the authors of the tracts he cites, in the case of the latter unquestionably the first such identifcation in print. ${ }^{17}$ Although the role of Francis Hare, Marlborough's ChaplainGeneral, in writing in defence of the Whigs and the General was also known to the ministry, ${ }^{\text {th }}$ the fact that Boyer mentioned Hare by name and apparently Walpole for the first time may be indication of some closer connection, probably through Maynwaring.

The principal thrust of the Whig press after 1710 was the defence of the late ministry and Marlborough and an unceasing attack upon the Tory negotiations for peace with the French. The reputation of Marlborough was a particular point of concern for Maynwaring. It is therefore interesting to note that Boyer picks up this cause and makes it his own in his newspaper. As he tells us himself in the Annals, "the Duke's friends, and impartial admirers, both of his immortal achievements and solid merit, were not wanting to defend his grace; so far, at least, as they thought they could do it with safety. And besides the Weekly Paper called the Protestant Post-Boy, lately set up; and now 
mainly taken up with his Grace's Vindication, a pamphlet was published 'by Thomas Burnel" for the same purpose, entitled, Our Ancestors as Wise as We."19

In a preamble to the first number and reprinled at the head of the second, Boyer declared that "the world had been imposed on by the Examiner" and the Post-Boy." 'The first had been written down by the Medley. This paper would devote itself "to supply the Publick with an Antidote against the poysonous assertions and insinuations of the said Post-Boy." For a period of several months Boyer did so. The paper also contained a substantial amount of foreign news throughout its relatively short life. The earlier issues often had foreign reports on the first page, and throughout its history the second page was usually devoted to foreign news and advertisements. But the accounts and commentaries on contemporary happenings, especially in England, had political overtones. Very often the tone and indeed the exact wording can be traced back to the Amals or the Political State. Sometimes all three employ similar if not identical language. Usually this duplication is limited to a paragraph or lines in a paragraph. The short foreign sections reflect the kind of work Boyer did for Roper on the Post-Boy itself. They are unexceptional. Aside from the duplication or paraphrases of materials also employed in the Political Siate the many slighting references to Roper and Swift are fully indicative of Boyer's dislike of both men. There are a few personal references. They relatc primarily to Boyer's prosecution for libel by the government. Therein may lie the basis for Boyer's brief but outspoken period of ardent Whiggism. When the 'Tory ministry sent Matthew Prior over to France in September, 1711, to conduct clandestine peace negotiations with the French, word accidentally leaked out. At the request of the ministry Swift wrote a satirical tract to put the best face on the revclation, A New Joumcy to Paris. Boyer, who had no love for Swift, responded on 12 October $^{2 n}$ with An Account of the State and Progress of the Present Negotiations for Peace, a tract that was all too accurate in its narration for the comfort of the ministers. His "Account" appeared later in abridged form in the Political State for September (published about 1 November) and was first summarized in the Protestant Post-Boy for 13 September 1711. Boyer protested that he had written the offending tract "with an honest intention of doing him [Oxford] further Service by setting him Right with the Party [Whig] that Writer firmly believes to be the Best English Men,"21 but to no avail. The prosecution was undertaken by St. John, and Boyer was caught in a large-scale effort by the Secretary to stifle the Whig press. Boyer also offended the ministry by other repotts on the peace negotiations; one in particular, in the issue of 27 Scptember, resulted in the incarceration of Harris, a bookseller who was onc of the publishers of the paper. ${ }^{22}$ It was thus with a 
sense of injustice mixed with pride that he alluded briefly in the Protestant Post-Boy for 27 October to the trial of some fourteen individuals including himself and Harris caught in St. John's dragnet. He never forgave St. John for this persecution.

The issues for the first several months, until the end of 1711 , are closely tied to a discussion of foreign affairs and the peace negotiations. As in the Political State there are frequent references to other publications. The primary focus is on the Post-Boy, the chief ministerial vehicle, and one in which St. John planted material to influence the public to support the ministry's foreign policy. Boycr made no bones about identifying Roper and mentioned him by name in virtually every issue, quoting offending paragraphs from the Post-Boy, and then rebutting them. He also made a number of references to Swift by descriptive words that left no doubt for whom the references were intended. When the Examiner resumed publication in December Boyer took up the cudgel against this Tory organ as well and continued for the balance of the life of his own paper.

In addition to these two newspapers, he alluded to a number of tracts, both Whig and Tory. In most cases the references and commentaries are duplicated in both the Political State and the Protestant Post-Boy and sometimes in the Annals as well. When the great bulk of his output is considered it is only natural to find that Boyer reused his material as often as possible. (In a like manner one can find much of the news sent in his manuscript newsletter duplicated in the Political State.) For example, in the Antnals he commented briefly on two tracts by Defoe, Rcasons Why this Nation ought to put a speedy cnd to this Present War and The Ballance of Europe. ${ }^{23}$ A fuller summary and commentary appeared in the Political State for October. ${ }^{24}$ The first of these two tracts was dealt with in the Protestant Port-Boy for 13 October. The comments on these two tracts are not so interesting as the tract Boyer quotes to refute the "spacious reasons" employed by Defoe to persuade the public the war should be terminated. Boyer notes that "most people perused with great satisfaction a pamphlet, entituled, The Taxes not grieuous."2n The words be uses to describe the author, "a Well wisher to a great Man [Oxford] now at the Helm; tho' at the same time, a Friend to the Whigs," are the kind he employed when referring to his own publications. On the strength of this reference the tract ought to be assigned at least tentatively to Boyer. A tract not referred to directly by Boyer in his newspaper but by inference is Reflections upon the Examiners Scandalous Peace, which may also have come from his hand, In some ways the most intriguing allusions are those to tracts identified with Arthur Maynwaring because they provide tenuous evidence 
that Boyer may have been one of the many writers under Maynwaring's supervision in the years he directed Whig press attacks on the Tories. In the Annals, for example, he cites with approval three tracts, all of which have been identified as coming from Maynwaring's pen. ${ }^{27}$ They are Remarks on the Preliminary Articles offer'd by the French King, A Vindication of the Present $M$ [inistr]y from the Clamours raised against them upon Occasion of the New Preliminaries, and Renarks apon the Present Negotiated Peace. ${ }^{28}$ Once again he summarizes and comments on all three at greater length in the Political State. ${ }^{20}$ The Remarks receives the greatest attention from Boyer. He reprints the tract entire in the Protestant Post-Boy, using it to fill the better part of no less than eight issues ${ }^{13 n}$ He suggests that the author "is generally thought to be the same who writ a pamphlet entituled, A Letzer to a Member of the October Club." This Iast is usually attributed to Francis Hare, whose works Maynwaring had a major hand in revising and editing, if not actually writing. ${ }^{\text {ai }}$

One last allusion to Maynwaring's work should be entered here, as it most closely identifies Boyer with him. On 21 November 1711 Maynwaring published a tract entitled $A$ State of the Bewdley Case. It dealt with the protracted struggles of the two parties to control the botough representation of Bewdley by reissuing the chares in such a way as to favour the party in power. Maynwaring first published the tract in 1709. In revising it for republication in 1711 he consulted the former Whig Clancellor Lord Cowper. Boyer, in describing the case as an introduction to the tract itself, which he published in the Political State, says "I made Application to a yery Eminent Lawyer [Cowper], as well as a publick spirited patriot [Maynwaring], in order to get a true state of the Bewdly Case; but his sudden departure for the country having hinder'd him from gratifying my desire, or rather the curiosity of the publick, I was obliged to wait till now [October], to give you a full account of that affair." ${ }^{\text {82 }}$ We know from Oldmixon that Maynwaring wrote the tract. ${ }^{\text {a }}$ When the revision was in preparation Godolphin wrote Cowper stating, "a friend of ours having prepared some collections for the press, in order to set the late representation of the house of commons in a truer light, is very desirous to be furnished with the truth of such matters of fact, as related to the charter of Bewdley." ${ }^{34}$ Boyer is so clearly acquainted with all the facts of the production of the tract that his knowledge can only be explained on the basis of a close association with the Whigs and specifically Maynwaring in their press campaign.

We have noted earlier that the Protestant PostBoy was largely devoted to foreign and diplomatic news, much of it rather straightforward, for the first several months it appeared. Thereafter its style changes, and one suspects that 
at this point other collaborators, perhaps Horneck, perhaps Maynwaring, perhaps still others, began to contribute. Horneck's hand is suggested in at least one issue, that for 10 November 1711, because it contains an obituary notice of Dr. John Ernest Grabe, an eminent Prussian divine and writer, who had settled in England after the Revolution. As Horneck's own father, Philip Horneck, had likewise come over from Germany to settle in England and had been accepted into the Anglican ministry, the two were undoubtedly in close communication, and Grabe must have been known personally to Horneck. ${ }^{35}$ The customary pattern of the Protestant Post Boy, beginning in December, was for the first page to contain an essay, often historical or moral, with historical examples and classical quotations from the Romans and Greeks. Boyer had the learning to employ this kind of material. But the subject matter is so unlike his other writings, which tended to adliere more narrowly to a narrative of current events, with fewer philosophical reflections, that one suspects writers such as Maynwaring and Oldmixon were closely involved. The style and content is much closer to the Medley, on which they collaborated from 1710 to 1711, than to Boyer's other writings. One also finds allegorical pieces and stories with pointed contemporary parallels, a favorite Maynwaring device. There are also panegyrics, which beroken more literary-oriented contributors than the prosaic Boyer. One suspects that Boyer's contribution was largely limited to the foreign news, which took up most of the second page. This would follow the pattern of his earlier contributions to Roper's Post-Boy.

Another feature of the later issues of the Protestant Pott-Boy is the regular inclusion of letters to the editor. This again is more characteristic of other writers, not least of all Richard Steele, and the paper takes on a substantially altered format with the introduction of this kind of material. Perhaps the most notable addition in the later issues is a series of political poents. Number $67(5$ February 1712), for example, devotes half its space to "A country tale" an allegory about Oxford, Mrs. Masham, and the Queen. Number 70 (12 February) contains a satirical poem on St. John, "The Brussel's Scrivener." Number 73 is devoted to a laudatory poem on Marlborough, "The Duke of Marlborough in Disgrace." Two numbers later the paper is devoted to an allegorical poem based upon Aesop's Reynard the Fox. Number 78 (1 March) contains another allegorical poem on the peace with a second shorter poem pointing up the lesson to be learned.

After the Stamp Act was passed, the Protestant Post-Boy forccast its demise once the Act took effect. Plainly Boyer and/or his collaborators were running out of steam. The paper hid been established primarily to defend Marlborough and at the same time frustrate the Tory ministry's efforts to make peace. Once 
the peace had been negotiated its raison d'ttre had vanished. Then too Marlborough had begun to withdraw from public life and had begun plans to go into exile, which he did at the end of the year. On 12 July 1712 the last number of the Protestant Post-Boy appeared. It may be worth noting that Boyer used the termination of the war also as an excuse to terminate his Annals. ${ }^{36}$ Very likely his newsletter and the Political State kept him sufliciently occupied. But he also recognized that the end of the war and the conclusion of the peace negotiations would reduce the amount of material he could employ in his publications and at the same time would also result in a lessening of public demand for news publications. Thereaftcr Boyer seems to have taken a less patently partisan stance. In the preface to the last volume of the Annats he alluded once again to his policy to be an impartial observer and commentator; yet for the period in which he wrote the Protestant Post-Boy his writings were scarcely in harmony with this policy. He himself seems to have recognized this and probably gave up the Protestant Post-Boy with a sense of relief. He had exposed himself too much to the party writers and was obviously resentful of their attacks. Nevertheless, during 1711-1712 he himself was a notable contributor to the paper war between the Whigs and Tories. And the newspaper he edited contains intriguing evidence of a close collaboration with more than one of the more notable Whig writers of the day. One may hope that further detailed analysis of the Protestant Post-Boy and a comparison of the style and tone of its contents, particularly the later issues, may reveal more precisely the nature and extent of the collaboration he undoubtedly received. Finally, one hopes that this brief survey will lead students of the period to study Boyer's acknowledged writings more carefully in order to appreciate the full range of his contributions to the press in the Augustan period.

\section{Notes}

1. Paul Hazard, The Earopean Mind, 1680-1715 (Cleveland: World Publishing Co., 1963), pp. 69-70.

2. There is a so-called second edition of 1735 regularly cited in tibliographics. In fact it is no more than a re-issue of the remaining stock of the 1722 edition with a cancelled ritle page.

3. I except here the Votes of the House of Commons, which contained only a summary of actions taken and then only of the lower house.

4. There are copies of the newsletter in British Library, Add. MS. 22,202. Boyer offered his newsletter to the Earl of Strafford in a Ictter of 25 June 1714, op. cit., vols, 97-8.

5. "Newspapers, Parliament, and Foreign Policy in the Age of Stanhope and Walpole" in Melanges offerts a G. Jacquemyns (Brussels, 1968); "The Role of the Dutch Republic :Is the Intellectual Entrepôt of Furope in the Scvententh and Eighteenth Centuries," Bitdragen en Mededelingen Betrefende do Geschiedenis der Nederiandet. 86 (1971), $323-49$. 
6. E. g., Peter Fraser, The Intelligence of the Secretaries of State (Cambridge: Cambridge University Press, 1956), pp. $41-5$.

7. I am grateful to Professor Henry G. Horwitz of the University of Iowa for pointing this out to me.

8. Some intormation on English newsletters is contained in my paper "Newsletters in England, 1689-1715: With special Referente to John Dyer-A Bywny in the History of England," in Donovan H. Bond and W. Reynolds McLeod, editors, Netwsletters to Newjpapers: Eightecuth Centwry Josurnalism (Murgantown: School of Journalism, West Virginia University, 1977), pp. 3-19.

9. "Daniel Defoe, Arthur Maywating, Rohere Walpole, and Abel Boyer: Some Considerations of Authurship," HLQ, 33 (1970), 147-49.

10. An atcouns of the Duel between the Duke of Hamillon and Lord Mohun (1713), cited in Snyder, "Daniel Defoc," p. 150, 12. 68. For the second publication, An Account of the State and Progress of the Present Negotiations of Peace (1711), see below.

11. See his letters to Harley in Historical Manuscripts Commission, Portand MSS, IV; Manusctipts of the Hotse of Lords, XI, 506; British Library, Portland loan, 29/127/4; and $A n n a l s, \mathrm{X}, 264$.

12. It begins by stating "I shall make them both [the quotations from the Examinet and Medley] start together on 3 August 1710 when the Examiner made his first Appearance by an Answer to that very Boyer, by his llemarks upon Mr. Pettecums Letter, whome lee has since, very unluckily, traduc'd for being unworthy of notice."

13. Phyllis 1. Guskin, "The Authorship of the Protestant Post-Boy, 1711-12," N\&Q, n.s. $22(1975), 489-90$.

14. A True Account of the Design, and Advantages of the Sonth-Sea Trade. Cf. John Robert Moore, Checklist of the Writings of Daniel Dejoc, 2nd ed. (Handen, Conn.: Archon, 1971), No. 213.

15. Annals, X, 241,265, 309 .

16. lbid., 238.

17. Ibid., Appendix, pp. 25. 44. Cf. Sayder, "Daniel Defoc," pp. 144-47.

18. Henry L. Snyder, "Arthur Maynwaring and the Whig Press, 1710-1712," in Literatur als Kritilh des Lebens, Festschrife zum 65. Geburtstag von Ludwig Borinski, ed. by Rudolf Haas, H.-. Müllerbrock and Claus Uhlig (Heidellkerg, 1974), p. 130.

19. X, 309.

20. Protestant Post-Boy, No. 18.

21. Political State, II, 645-46. Cf. Annals, X, 264-65.

22. Political State, $11,552$.

23. X, 250.51. Cl. Moore, Nos. 216, 219.

24. II, 581-89.

25. Annals, X, 251 .

26. Cf, Protestant Post-Bay, No, 26.

27. Snyder, "Arthur Maynwaring," pp. 131-32.

28. $\mathrm{X}, 265$.

29. II, 647-58.

30. Nos. 113-18, 120-21.

31. Snyder, "Arthur Maynwaring," p. 128.

32. Political State, II, 598.

33. Life and Works of Maynwaring (London, 1715), pp. 316-23.

34. Snyder, "Arthur Maynwaring." p. 129.

35. See the entry for Horneck in the DNB.

36. See the preface to the last volume. 


\section{Dunton's Post-Angel: \\ Messenger of Remarkable Providences}

\section{BF Anntael. Jenktns}

Early in 1701 the custoners browsing among the current books and pamphlets at the shop of A. Baldwin in Warwick Lane found a new periodical entitled the Post-Angel. If a cursory reading of its title page persuaded the prospective customer to pay the shilling asked and take it home to read more carefully, he found a long preface explaining plans and purpose for a monthly journal designed to offer pious instruction by means of a collection of the Remarkable Providences of God's Judgments and Mercy. In the initial issue, dated January 1701, the reader was promised a "Discourse upon all Subjects," and on the whole that promise was fulfilled. The Post-Angel appeared for twenty-one months, through the number dated September 1702. In format a quarto pamphlet printed in a single column, it varied from ten to seven sheets in the monthly issues, and in its entirety ran to well over a thousand pages.

The length and diversity of the Post-Angel suggested that it was a substantial addition to the periodical press as the new century began. Moreover, a close look at the contents of the Angel reveals that while diversity and length were two of its major characteristics, there were other significant features as well. The editorial policjes the Angel's amanuensis established, the clever organization of both original and selected material used to make it a "Universal Entertainment," and the handling of the various departments set up to encompass the Angel's wide domain show the Post-Angel exceptional in form and design as well as in diversity and length.

There was no acknowledgment of authorship in the first issue of the Angel, but the hand of John Dunton, well-known bookseller, publisher, and projector, was unmistakably evident; moreover, the proposal to gather a collection of Remarkable Providences was no novelty to those readers from the middle class Dissenters for whom the Post-Angel proposed to serve as messenger between heaven and earth. The unique feature of the Post-Angel was the combination of a collection of Remarkable Providences with a "Spiritual Observator" accompanying each one, here presented for the first time in monthly installments.

The organization and general editorial policies of the Angel were set forth in the first number on a neat and quite dignifred title page and in a long preface. "In the beginning there were "Five distinct PARTS" listed in order as 
1. The Remarkable PROVIDENCES (of Judgment and Mercy) that hap'ned in JANUARY, $\& c$.

II. The LIVES AND DEATHS of the most Eminent Persons that Died in that Month, $s c$.

III. A New ATHENIAN MERCURY; Resolving the most nice and curious Questions proposed by the Ingenious of either Sex.

IV. The Publick NEWS at Home and Abroad.

V. An Account of the BOOKS latcly publish'd, and now going to the Press. And as a kind of identification there was an appropriate quotation:

Only that $A N G E L$ was straight gone; even so, (But not so swift) the MORNING GLORIES How.

QUICK POST! that with a speedy Expedition, Flies to accomplish his DIVINE COMMISSION.

God's wing'd Herald, Heavens swift Messenger, 'Twixt Heaven and Earth the TRUE INTERPRETER. Coulcy

In the lengthy preface that followed the title page Dunton set out his plan carefully, as his own explanation makes abundantly clear. His was a special journal with special correspondents; the Post-Angel would inquire of the news from heaven, an inquiry that was to be made by settling a correspondence with a Post-Angel. Dunton explains:

By POST-ANGELS, I mean all the invisible Host of the middle Region, that are employed about as either As Friends or Enemies. By the NEWS they bring us, I mean, not the outward, lower, visible Parts of the Heavenly Otbs, but the supreme Imperial Part, the Seat of the Blessed, which is out of sight, and the reach of human Sense .... and I have settled such a Correspondence, that I hope to insert several things worth reading out of the common Roud of News; for sure a Post-Angel is able to out-fie a Post-Master, Post-Man, and Post-Boy; and those lesser Fliers, the English and London Post.

Dunton followed this statement with a closely documented discussion of angels, citing such authorities as Richard Baxter's The World of Spirits and Jolin Aubrey's Miscellanies and rccounting a couple of examples from Dr. Nepier's "Papers." Warming to his task, Dunton quoted Scripture, cited the Church fathers, added testimonies of those who were upon their death beds, and gave a homely example or two proving not only that angels exist but that they visit chosen ones upon the earth. These messengers administer God's Providence, Dunton said, and by their help, "we may ascend Pisgah by degrees; we may 
see the outward skirts of Heaven," And when the Angel has carried us inco heaven "we shall have a prospect of the whole Hemisphere; we shall then fully know the sublime and profound Mysteries of Saluation... the depth of the Providences of God,..."

Yet for all his concern with angels Duston was a practical man and realized, as he said, that "Method and Order, render the most difficult Enterprizes easic." Each part of the paper had a clear identity, the proposed contents of each being clearly outlined in the preface. The first section, "History of Providence," was to be a collection of Remarkable Providences; the second part, "The Lives and Death," would finally become "a compleat History of modern Lives"; the third part, a new Athenian Mercury, would reprint questions and answers from the volumes of the old Athenian Mercury, long out of print, and answer new questions; the fourtl part, public news, would be an abridgment; the fifth part, an account of books, would be a catalogue, not abridgments or extracts. Finally, after each of these sections there was to be an "Observator" designed to promote spiritual improvement. Dunton proposed to fill his journal cach month by contributions and questions from his readers. He promised to use libraries, the help of his friends, and his own observations to supply the "observator" atter the entries, thus making his Post Angel both a "SPIRITUAL EMPROVEMENT" and " $\triangle$ UNIVERSAL ENTERTAINMENT:" There could hardly have been a more ingenious plan for a journalist to devise; within the pages of the Post-Angel the reader could recount his own stories along with those of notable authorities, and in addition he could have his questions answered, his news presented in selected items, his catalogue of new books kept current, and a generous supply of dying words and pious sentiments from the "Lives and Deaths"; he might even bave the privilege of seeing an original life of one of his friends and acquaintances. Dunton suggested that such original lives be sent.

Dunton's plan for his journal showcd clearly his knowledge of the Angel's potential audience and thus Dunton's own business acumen. In the seventeenth century, when there were no facilities for borrowing books, readers with limited means who could not acquire an extensive personal library found collections very useful. The booksellers and publishers, recognizing this situation, provided dozens of volumes, especialiy collections of sermons, dying words, curiosities, wonders, and providences. Dunton had had his share in these publications. In his days of trade he had published The Wonders of Free-Grace: Or, A Compleat History of All the Remarkable Penitents That have been Executed at Tyburn, And elsewhere for these last Thirty Years. He had also helped publish William Turner's A Compleat History of the Most Remarkable 
Providenees both of Judgment and Mercy, which have Hapned in this Present Age. Dunton knew Increase Mather, published some of his sermons and pamphlets, and undoubtedly was very familiar with Mather's collection, $A n$ Essay For the Recording of Illustrious Providences. Dunton, along with several other publishers, helped see through the press Richard Baxter's Reliquiae Baxterianae, a volume filled with Baxter's examples of the Remarkable Providences in lis own life and additional examples he had observed or that had been related to him. Two of these books with which Dunton was involved, the Turner History and the Baxter autobiography, were folio volumes that included hundreds of examples of Providences. The collection of Remarkable Providences was already well established before the Angel began to report them. ${ }^{2}$

Dunton and all his contemporaries who collected Providences agreed upon several propositions. For example, it was man's duty to be constantly aware of God's Providences of Judgment and Mercy, to observe them upon every hand, and to collect them for future references. The Providences of Judgment, far more frequent than those of Mercy, included such items as sudden death, shipwrecks, murders, suicides, and a variety of the sins of the flesh-adultery, Fornication, and inordinate affections. The Providences of Mercy, which included those of wonder and deliverance, attested to the power of God to overrule the world of nature and men as well as the invisible hosts of heaven. Upon all thesc Remarkable Providences Dunton proposed that the Angel offer comments.

The "Spiritual Observator" used here as a device for periodical publication was the unique feature offered first in the Post-Angel. Within the plan of the collection of Providences of Judgment and "Spiritual Observator," the content, the design, and the conduct of the Post-Angel were guaranteed. The fact that Dunton succeeded in such a complicated and diverse scheme for so long a time suggests that his knowledge of the views and interests of his audience was quite accurate. The Post-Angel itself confirms our thesis. A brief review of the principal categories of the Providences and an equally brief comment about the "Spiritual Observator" as a device will serve as an introduction, however slight, to the views and interests of that audience.

For the monthly reader of the Post-Angel the succession of events that made up Dunton's promise of rernarkable occurrences probably seemed sufficiently various and entertaining to sustain interest and prompt curiosity. But when we begin to view the Providences from our vantage we see that "sudden deaths" were the most frequently reported Providences. Sudden deaths were items 
worth collecting because they gave warning of the brevity of this life and emphasized the need to be ever mindful of the world to come.

Sudden deaths were brought about by a variety of causes-accidents, floods, lightning-all clear evidence of the mighty hand of God. Mrs. St. John, standing too near the chimney, accidentally caught her lines on fire and was instantly enveloped in flames; ${ }^{3}$ " a person living in Coleman-street ... fell down dead, and never spake one word." An apothecary, one Mr. Dalton, died in his sleep, and Mr. Lawrence had the misfortune to be thrown from his horse and break his neck." Such accidents served as texts for the Angel to urge constant vigilance upon its readers lest they have "not so much time as to say Lord have mercy on my Soul."' Death was a solemn occasion marked by repentance, prayer, and dying words of blessing and advice, and it should be adequately prepared for.

Some sudden deaths were brought about by the deliberate, wilful behavior of wicked people; among those caused by such sinful actions were deaths resulting from excessive drinking or drunkenness. One entry included a long list of well-known drunkards headed by "the famous Bacchus" who advertised that he could drink off five gallons of claret twice in one evening. ${ }^{7}$ Frequently the account of drunkenness was only a part of a more extensive relation of judgment. One John Hawkins, who, "drinking with others very strong Beer, happened to drink so much, that he died in two Hours," was actually a very wicked man. He was heard to say repeatedly "that he did not believe there was either a God, or Devil, Heaven, or Hell, and the like." The Angel's comments on Hawkins were largely about atheism and the Being of God, but in the discussion the point was made quite plain that Hawkins had no time to repent, since he died while he was drunk.

Another accident that involved drinking and sudden death occurred one night when seven men, "vcry much in Drink," traveled down the river to London Bridge. They wrecked their boat against the piles; three of them were drowned, and the four who saved themselves "went and drank all Night to dry themselves" after they were rescued, all the while declaring that they knew nothing of the fate of their fellows." The topic of the essay that Dunton wrote following this relation was the "Sabbath-breakers" and those who do not take their religious practices seriously. The accident had occurred on the Sabbath, and Dunton declared of such offenders, "If you should tell them of Repetition [sic], Meditation, Family Dutics, Catechizing, Exhorting, they must beg your Pardon there; they do not design to make the Lord's Day a Burthen to them, ..." Sudden deaths resulting from sinful pleasure were judgments of 
warning and called forth condemnations on those who survived such accidents as well as those who did not. ${ }^{10}$

The remarkable Providences revealed by shipwrecks were properly dramatic; the longest account of a shipwreck appeared in two versions, one of which gave the details from a survivor. A ship bound for Lisbon ran into a violent storm and, falling upon the rocks, went to pieces. The master and six men drowned immediately, but nine of the men managed to remain alive by eating limpets, shell fish, and finally the ship's dog, until they were rescued because of the insistence of a boy who dreamed of their plight and begged his father to sail in their vicinity." Another shipwreck was memorable for the fact that a Jone sailor escaped death by being tossed free of the ship to the top of a rock." In commenting on both cases the Angel's observation upon shipwrecks shifted from the tragic loss of life to the need for reformation on the part of sailors, an attitude thoroughly familiar to the $A n g e l$ 's audience if not to us. Dunton's readers knew that sailors were especially wicked and never called upon God except in the midst of tempests.

As the Post-Angel reminded its audience, there were of course innumerable possibilities for accidental death. The Providences of Judgment were revealed in the bizarre as well as the commonplace. For example, there was the boy who, making a jest of the wry faces of the criminals he had seen, hanged himself. A man set upon by dogs died of his wounds; an old woman going across a stile caught her head string in the hedge and broke her neck; a man hit over the head by a falling beam never regained consciousness. ${ }^{13}$

In the world that the Angel reported, death and its attendant, crime, were on every hand. In addition to sudden death by accidents, shipwrecks, fires, and miscellaneous causes, there was another group of Providences in which crime, death's companion, had a principal part. Indeed in two categories, suicide and murder, deatl was again a principal player. Sujcides were reported frequently in the Post-Angel, but the details of the reports and the manner in which they were viewed varied widely and in a very significant mamer. According to the view of the Protestant church groups, suicjde was self murder and as such a crime against society as well as against God. Moreover, for the Post-Angel suicide held the additional danger of leaving no time for repentance and dying words, even though it was not a mortal sin. Indeed, frequently the problem was not primarily the final state of the soul of the victim but the set of circumstances out of which suicide developed. Thus in many instances the emphasis of the report is shifted from a discussion of suicide itself to a sermon on sodomy or witchcraft or sinful pleasure. To the Angel and its audience of 
sensible middle class Dissenters, suicide was the by-product of sin, not the result of some psychological maladjustment of the victim.

The range of circumstances in which unfortunate people committed suicide, like the scope of the Remarkable Providences themselves, was as endless as human misery and included representatives from the higl and the low-the sinful, the weak, and the pathetic, Mr. Jefferies married a woman whom he thought to be a widow, but, her husband appearing after some years, he was obliged to leave his wife and go to London. He was chosen pastor to a prosperous congregation, but he found that there was a witch in their number. Jefferies, as the pastor, felt that he must turn her out of the church. After he had taken this action she came back and haunted him until he killed himselE: ${ }^{14}$ A young man disappointed in love took his own life by cutting his throat with a razor. ${ }^{16}$ A servant girl cheated by her spark drowned herself when she discovered that he had coupled with another. ${ }^{16}$ A young man married one of his farher's serving maids and was theretpon disinherited. His wife died from neglect, leaving their two small children to the care of "the unfortunate widower, whose uphappy circumstances plung'd him so deep in melancholy and discontent that his Distraction grew fatal, made him consult measures against his own Life, and commit the last offence against God and nature."17

The Remarkable Providences of murder, like those of suicide, served the Angel as material for dissertations on the dangers of wicked companions and sinful lives. Hudson Strodman killed his fellow apprentice, robbed his master, and set the house on fire. Before he was hanged he repented and confessed that first of all he had been a Sabbath-breaker and had consorted with evil companions. ${ }^{19}$ Langtree, a blacksmith, killed his wife and burned her body, bu he was convicted, "the fingerioints of her hand being produced in court." He confessed that he had forsaken her for another and wished to be rid of her to have the other. In both cases, however, the murderers repented and the Angel cnded the discussion with comments about God's forgiveness, even of the greatest of sinners.

The Providences of Mercy, while they were less frequently the concern of the Angel than were the Providences of Judgment, were no less notable. The Providences of Mercy were divided between those of "Wonders" and those of "Deliverance." Those of "Wonders" were of unusual people, unusual creatures, or unusual expressions of nature. The extraordinary people singled out as Providences of Mcrcy were those who were very strong or vcry fat; those who lived to be very old or who had a grcat many children. In the vicw of the Post-Angel these Providences of Mercy were to be noted as evidences of God's power and might or as examples of His special favor. The first issue of the 
Angel cited two examples of these extraordinary people. The famous Amazon, Balthazar, who served in the French army as a soldier, wore a sword, and attended her two children, introduced the type. In this same issue a man who had lived to be over a hundred and fourteen years and had outlived "16 Popes, 5 Emperours, 4 Kings of Spain, 4 Kings of France, and 6 Kings and Queens of England, and had 140 grandchildren, to the fourth generation"20 continued the Angel's catalogue of wonders. There were instances of people who had many children or who had good memories, and several examples of women who had outlived a number of husbands. One of these women lived in "Maidstone in Kent, ... a brisk, jolly woman" who had buried nine husbands and "lately Marry'd a Tenth... And considering her Luck in Burying of Husbands, may (probably) live to double the Number."21 The wonders of extraordinary creatures included great or unusual fish and the white elephant exhibited in Fleet Street. ${ }^{22}$ Some of these wonders were in the heavens-thrce suns, two blazing stars. ${ }^{28}$

The Providences of Deliverance were varied and astounding. They included items such as the story of the woman who was buried alive but who was rescued literally from the grave the day before she gave birth to twins.. ${ }^{24}$ One reader wrote that as a child he had been playing at marbles so intently that he failed to hear a great cart coming along the street. The horse kicked him down, the cart ran over him, and as he explaincd, "I ... had been pierc'd in sunder, had it not been for a stiff-bodied Coat I had then on, which was a Fence against so great a Mischief." ${ }^{255}$ The stories of sleep-walkers were told as stories of deliverance. One such account told of the man who would rise from his bed, unlock the doors, go down the stairs, saddle his horse and go for a ride, return, repeat the routine, and so again to bed. A friend sent in the report of Grace Niles, a servant girl, who walked several miles over the moors and returned to her home, having afterwards no remembrance of her journey. ${ }^{\mathbf{2 6}}$

Discussing the incident of a young man who fell headlong into a ton of scalding mash yet escaped without injury, Dunton quoted Increase Mather, agreeing with Mather's view, "That the ways of the Almighty and his dealing with Particular Men, (as well as those of his common Providence and Judgments) are so strange, and filled with Variety of Spiritual Stratagems, that we may well say of him, His Paths are in the deep Waters, and his Footsteps are not known." ${ }^{\text {"27 }}$

The Spiritual Observator that accompanied each Providence was the means whereby Dunton made pertinent the application of the Angel's Remarkable Providences. Taken together as a single unit, the Remarkable Providences and the matching Spiritual Observator made up a quite precise form of its own. 
Closely related to the informal essay and the sermon, it was neither; instead, it had several distinctive features that set it apart as a separate form. Perhaps a few characteristics of the Providence-Observator will suggest these distinctive features. ${ }^{28}$

The scheme for organizing the Providence-Observator was logical and simple. First there was the presentation of the remarkable circumstances of the Providence, next a review or comparison of these circumstances with others of like instances, a review which frequently included incidents from the Bible, the Church fathers, or other authorities, and finally, the application of the Providence to the lives of Dunton's readers. This form was closely related to the informal essay of such writers as Montaigne, and by its very purpose and its specific view of the interrelations of the world of angels and the world of men it had certain distinctive features of its own, dictated by God's Providences and by observations that were spiritual not secular. Dunton began with an account of the Providence, then selected suitable material for the Spiritual Observator by first choosing a point of emphasis which, while it was derived from the Rernarkable Providence, could itself serve as a proper thesis for spiritual commentary. Having done this, Dunton could then organize the whole of his composition in such a way that his reader would be properly instructed by the Spiritual Observator even though Dunton intended him to be entertained as well. This Providence-Observator pattern was followed in virtually every issue of the Angel. Purpose dictated the form-the sequence of incident, example, and expostulation. Since several subjects were given repeated entries, the form of the Observators was the key needed to supply the variety of application demanded by the endless scope of God's all-encompassing Providence. Dunton's ability to supply these endless variations on a theme within the categories he established in the Post-Angel showed remarkable ingenuity.

The contrasting way in which Dunton handled two severe storms illustrates his careful use of his particular form. A gentleman and his party riding along the road realized "on a sudden there was a wonderful stillness, and every thing round us black and gloomy." The gent'eman stopped to put on his cloak, "expecting a great Shower; . . and that wery Mintue my poor Boy and Mr. Miller's Servant, with both their Horses, were struck stark Dead." The people in the village below the hill declared that they saw "a whole shower of Fire and Lightning fall," and when they went to see about the servants they found "Mr. Miller's Man all Burnt, the Crown of his Hat struck out, and his Skull broke, the Buttons of his waistcoat struck into his Body;..." The other servant and horse had not "the leat singe, or any manner of visible Ailment; but look'd as if they had been both alive." In this case the Observator focused on 
the subject of lightning; it concluded with Dunton's pronouncement that "there are several sorts of Fire, and that it is no impossibility, for the Damned, when in Bodies, to have a Firey Torment." The second storm occurred in the winter after a warm period had melted the ice and caused flooding, the ice damaging bridges and houses as it broke up. Several people drowned, among them the Earl of Westmeath and his Countess. Dunton's Observator here followed the pattern precisely. He reminded his readers of other memorable storms, pointed out that people had been killed before, and after his review wrote an extensive dissertation on the thesis that the Devil, by God's permission, is allowed "to produce Storms and Tempests."

These two providences are much alike in that they both record in some detail notable incidents of a natural weather phenomenon, but in the applications that Dunton chose to make they differ widely. In each case, however, after the point of emphasis has been determined, the pattern follows--first an account of the Providence, then a review or comparison of it with others in its category, an application of lessons to be learned, and a review of other instances that support the same lesson. In this last Dunton frequently digressed to bring in related topics which in turn could be examined. The form offered cndless possibilities.

Even for Dunton it must have been tather difficult after giving examples of sudden death in one entry to repeat the performance after every similar entry that followed. Two examples of sudden death will suggest the characteristics of nany others. The first Remarkable Providence reads:

On Thursdav last, one Mr. Blackston, a Sorter in the General Post-Office fell down a pair of Stairs, and broke his Neck.-And Mr. Priest, a Letter-Carrier, shot himself dead with a Pistol. ${ }^{\text {Bt }}$

In the Observator Dunton begins:

If we respect the Majesty of Gnd himself, what can be more odious to him, than to see his own Image defac'd, by shooting or hanging our selves? . . True Saints go up the Hill to Sion, ... but the Self-murderers, Jike the Devils in the Herd of Swine, run violently down the Hill to Hell; . . . those that (like Blackston) came to an untimely End by a Fall, or by meer Accident, we may have more Hopes of their Salvation, than those that (like Priest) murder themselves: But 'tis a false Notion to think, the saying, Lord have Meray upon us, at last, is enough to save us.... Surcly we cannot be certain this Day, whether Death may lorge with us before the next; if the least prick of the Foot may make way for 
it, if the smallest Passage be a Door wide enough for it to come in at, ... a Thorn may be as mortal as a Bullet, or a Fall from a Pair of Stairs."

Sometimes the Providence entry sent in by a reader is quite obviously authentic. For example:

As I am a great Admirer of your Worthy Design of the Post-Angel, I hope you will admit a Place in this Month's Angel for this following Relation; I should be extremely glad to have your Spiritual Observator upon it, Viz.-One-Martin, who was a Cambridge Carrier for several Years, did last Saturday, the 26th of July, 1710, go with a Friend of his to see the Ship, call'd the Royal Sovercign; and when he came a-shore at Billingsgate, from seeing it, did complain that he was very dry; but his Friend not being inclinable to drink, put it off, till he came to the George and Vulture, a Tavern in Cornhill; where calling for a Pint of Wine, whilst the Drawer went for it, he dropp'd down dead, and, as I am inform'd, never spake more. This being nothing but what is Truth, I hope you will comply with my Request, which is, to have your Spiritual Observator, and you will oblige yours,

$$
\text { R.J. }{ }^{\text {ss }}
$$

This is the familiar pattern-someone dies withour a moment's warning or without the opportunity to utter a single dying word. The Observator obliges with remarks on the sudden death of "Martin the Cambridge Carrier, who dropp'd down dead at the very time he design'd to be merry with his Friend: Watch thereforc, for ye know not what Hour your Lord cometh."

I don't hear but Martin had a very sober Character; and if he was fit for death, he had a Happiness in having such a quick Passage to Heaven; But, generally speaking, sudden Death is a Judgment; and therefore 'tis part of our Litany, From Studen Death, good Lord, deliver us. ${ }^{84}$ ।

Some months later, after a brief entry about two deaths Dunton gave a set of directions to "prevent being surpriz'd by Sudden Death." Upon arising one should let his "Thoughts ascend, that Grace may descend;" he should conduct his life to pay duty to those who deserve it, "Forgive, but Revenge no Wrongs," be careful of the "slandrous Tongue, and control that unchaste Eye;" one should be mindful of all things and do as he would have others do to him. And finally, "when you go to Bed, read over the Carriage of yourself that Day. Reform what is arniss, and give Gol thanks for what Temptations you have resisted, ... and so commit thy self to him that keeps thee." If the reader will 
follow the advice of the Angel, then he "can never be said properly to die suddenly; for tho' Death may surprize thee, it can never hurt thec."'s

Sometimes the cause of death provided Dunton with the clue for his Observator. Several notable examples of excessive drinking gave him the opportunity to expostulate on drunkenness and made them assume an importance beyond their brief entries. A death caused by too much drinking was reported: "About Three Weeks ago, a Person going on Board an Homewardbound Sbip in the River, to visit some acquaintance, drank to that Excess, that he died that Night on Board the Ship." ${ }^{\text {sB }}$ The Observator that followed was quite long, cautioning the reader that "we drink no more than does just BRISK our Spirits, and make our Hearts GLAD: But 'tis hard to keep to a just Measure." The examples cited ranged from Alexander the Great to "THREE DRUNKARDS, at Bungey in Norfolk," one of whom "fell over a Bridge, and was drowned; a second fell from his Horse, and broke his Neck; and the third, sleeping on the Ground, froze to Death." The discussion ended with the observation that a drunkard will frequently drink more wine

than wou'd keep a Poor Family for a Fortnight. But the Divine Vengeance follows close upon the Heels of this $\mathrm{Sin}$; it sometimes strikes the Sinner dead in the Height of his Debauch, (as is seen in the present Instance,) and (except he's sav'd by a Miracle) sends his Soul to Hell. ${ }^{\text {g }}$

Immediately following this Observator Dunton not only listed great drinkers among the men but also discussed "SHE-BIBBERS." One woman was struck dead "perswading her Guests to Drunkenness," and another wornan "with Three of her Neighbors, agreed to drink up a Barrel of Drink, which they did, and died presently." In fact, this Observator on these instances grew so long that Dunton ended it with an apology:

I hope as DRUNKENNESS is a Reigning Vice, (both in Men and women,) that I han't been too large in my OBSERVATOR upon it: But to make amends, I'll be Briefer in the rest that follow's; for I find the chief Complaint against my Journal, is, that I take too much Pains in the writing of it, and (which is a Fault not often complain'd of) that I give my Readers too much for Monley. ${ }^{38}$

Perhaps, after our investigation of the Angel's collection of sudden deaths, dire accidents, and celestial wrath, we should recall briefly the pious design of its plan. According to its view, "Every Sin strikes at the Soul and wounds it;","sh and as Dunton concluded after a report of an unexpected fire, "We see there is no stable Happiness in this World; . . " ${ }^{n}$ Men must keep constantly in mind 
"that there is a Divine Pouer that orders and disposes all Things, and make them become Servants of the Most High God, whose Mercies are over all the Earth."11

Dunton's Providence-Observator form, then, made up an effective way for Dunton's readers to be entertained and instructed at the same time, to recognize examples of God's Providence and of man's devotion, to provide both "Universal Entertainment" and "Divine improvement of every remarkable occurrence," as Dunton had designed. For Dunton and his readers here was one final lesson in the Remarkable Providences-Spiritual Observators: if one will avoid certain overt acts-for example, swearing, getting drunk, committing adultery-and will shun the world and its temptations, he will be certain of Divine approbation. Moreover, his instruction is made easy through a series of entertaining examples, presented in a satisfactorily scholarly manner and made plain through much repetition and simple analysis. God is everywhere. His Remarkable Providences are attested to by the readers of the Angel; His judgments and precepts are explained by means of Dunton and his Spiritual Observator.

Framing his day by morning and evening worship services in his hom stopping at noon for a sermon, going to Smith's Coffechouse or the Ner England Coffeehouse, where his fellows gathercd, a pious Dissenter was a stantly reminded of his religion. It was a part of his government, his busine and his daily life. It surrounded his every action and gave meaning to eve incident and observation from one day to the next. In the years 1701-2, $t$ years of the Angel, he had a periodical to provide him with a collection Remarkable Providences and to guide him in reading them correctly.

Our interest in the Remarkable Providences and Dunton's Observators . certainly not that of the readers who helped him with his collection, but our review of the beliefs and attitudes that prompted the collection and preservation of Remarkable Providences provides us with a key to an understanding of that expanding world of the early eighteenth century that produced Defoe, the Wesleys, Fielding, and scores of periodicals and pamphlets by less well-known writers, all reflecting, in one way or another, the view of the pious Dissenter and the Post-Angel. Morcover, in the combination of entertainment and instruction which Dunton devised for his Remarkable Providences-Spiritual Observators, we see in embryonic form the long succession of instructive fiction that developed later in the century. Defoe writing about himself said, "I have gone through a Life of Wonders, and am the Subject of a vast Variety of Providences." ${ }^{\prime 2}$ Stephen Charnock first expressed the idea more generally when he said, "God discovers his mind to us by providences," and then con- 
tinued, "Though we are sure God hath decreed the certain event of such a thing, yet we must not encourage our idleness, but our ditigence." ${ }^{\text {s }}$ Early in the century the Post-Angel provided a proper way for discovering Gol's "mind," and the Spiritual Observator developed by Dunton encouraged the "diligence" of his readers to understand and read aright the lessons revealed.

\section{Notes}

1. The text of the Post-angel used for this article is that of pholostats of the original sheets in the British Musetim. Nowhere on the title pages of the separate issues is there any credit for aurhorship given, but it must have been elear from the heginning that Jolin Duncon was the projector. Sce his own The Life and Errors of lohn Dunton (London, 1818), $I, 199-200$.

2. For a more detailed study of Dunton's associations with these collections of Remarkable Provideners see Annibel Tenkins, "A Study of the Post-Angel, 1701-1702," Diss, University of Nortl Carolina, Chapel Hill, 1965, pin, 161-79.

3. Post-Angel, January 1701, p. 3. In refereness to the issues of the Post-Angel the month and year will be given, followed by the page number printed in the $A$ ngel. Since the pagination is quite conlused in a number of places, the correct page number will be given in brackets.

4. July 1701, p. 25.

5. January 1702, p. 15.

6. July 1701 , p. 26.

7. March 1701, p. 172, [178].

8. June 170$],$ p. $412,[400]$.

9. October 1701, p. 204, \208].

10. Jbid, P. 205, [209].

11. January 1701, p. 36, [18].

12. March 1701, p. $169,[175]$.

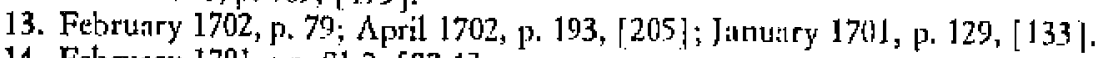

14. February 1701, ]p. 81-2, [83-4].

15. May 1701 , p. $324,[312]$.

16. June 1702, pp. 301-2, [315-16].

77. July 1702 , pp. 5-6.

18. April 170l, pp. $252-54$.

19. August 1701, pp. $77-80$.

20. Jantary 1701 , p. 4 ; pp. $33-40, \mid 21-22\rceil$.

21. September 1701, p. 135.

22. October 1701, P.P. 226-27, [230-31]

23. January 1701, $\mathrm{pp} .27-28,[9-10]$; January $1702, \mathrm{pp}, 17 \cdot 19$.

24. August 1702, pp. 63-65, [67-69].

25. July $1701, \mathrm{pp} .4 .5$.

26. April 1701, Pp. 247-49; October 1701, p1. 210.14, [214-18].

27. May 1701, p. 323, [311]. For the Mather reference sce Increase Mrther, Remark. able Providences (London, 1856), p. 259.

28. The Observators followed each of the sections of Lives, New Athenian Mercury, News, and Books as well as the section of Remarkable. Providences, but after the July 1701 issue there was generally only a singie Observator for the whole section of Lives, New Athenian Mercury, News, and Bools, whereas there continued to be a separate Observator inr each scparate Remarkable Providence entry.

29. January 1701, p. 32, [14].

30. Ibid., p. 36, [20]. 
31. November 1701, pp. 306, 262.

32. Ibid., pp. 306-7, 262-63.

33. September 1701, p. 131.

34. Ibid., pp. 132-33.

35. January 1702 , p. 16.

36. March 1701, pp. 171, 177.

37. Ibid., pp. 172-73, 178-79.

38. Ibid., pp. 177, 183.

39. Ibid., pp. 151, 155.

40. April 1701, p. 250.

41. July 1701, p. 3 .

42. Daniel Defoe, Defoe's Review, ed. A. W. Secord (New York: Columbia University Press, 1938), VIII, A3r.

43. Stephen Charnock, The Complete Works of Stephen Charnock (Edinburgh, 1864), I, 59. 


\section{Steele and his Answerers: \\ May 1709-February $1714^{*}$}

\section{By Edward A. Bloom and Ltulian D. Bloom}

Steele groped his way into political journalism. And immediately he found hirnself in a state of war, one which lasted for almost five years. During this period he advanced in the ranks of the Whig party from apprentice to number one propagandist. He learned to move with the times: when to write softly and when at the top of his voice. He acquired the scribbler's facility in evasive action. Yet he became as skillful in adjusting his pace to the object of pursuit. Emotionally he developed a toughness which enabled him to push Tory insults beyond the edge of thought. The constant, however, in his first paper war is that he remained the outsized target. The tussle began with Delarivière Manley, "an exasperated Mistress," whose intimacy he had probably enjoyed in a now-and-then fashion between 1695 and 1702 or 1703.' Clearly their feelings for one another lasted long enough for her to pick up information about the young captain. From these ligbtly buried memories she sketched his portrait for the first volume of The New Alalantis, which appeared on 26 May 1709, just a month and a half after the Tatler came to London.

Why did Mrs. Manley satirize Steele in a fiction designed, first, to praise under transparent pseudonyms the Queen's new favorites-Harley, Peterborough, Mrs. Masham-and, then, to laugh into scandalous oblivion the Marlboroughs, Godolphin, and the assorted Whigs who comprised his coalition government? Why, indeed, did she add him to her "faint representations, some imperfect pieces of painting, of the heads of that party that have misled thousands?"2 In so impressive a Whiggish council, Steele had minor standing. $\mathrm{He}$ had been part of a military and social life, had written some poetry, a Christian apologetic, three plays, and for not quite two years had edited--and continued to edit-the London Gazetze. But for the moment he was only a journalist in the Cockpit, occupying "a pretty Office with Coals, Candles, Paper \&c." As the

* This article is indebted for facts and spirit to the work of several people and we wish to express our gracitute to thein at the outset of this paper: Richmond P. Bond, The Tatier: the Making of a Literary Joumal (Cambridge: Harvard University Press, 1971); Calhoun Winton, Captain Steele (Baltimore: The Johns Hopkins Press, 1964); Bertrand Goldgar, The Curse of Panty (Lincoln: University of Nebraska Press, 1961); R. W. Achurch, "Richard Steele, Gazetteer and Bickerstaff," in Studies in the Early English Periodical, ed. Richmond P. Bond (Chapel Hill: University of North Carolina Press, 1957), pp. 49-72. - 
"lowest minister of State," who rarely made policy decisions for a newspaper, he "cooked" the news upon the orders of Sunderland, the Secretary of State for the Southern Department, and Addison, his Lordship's Under-Secretary." Still he had proved that he could follow ditections expertly, culling from the news dispatches those intelligences which minimized domestic discontent and highlighted sot merely the victories of the War of the Spanish Succession but the courage of its leaders, civil and military, at home and abroad.

Steele may have been selected for punishment in The New Atalantis because of his performance as Gazetteer. Or he may have been a last minute choice, Mrs. Manley's answer to the threat of the Tatler which burst upon the capital with its satires of easily identifiable persons. So Abigail Harley voiced more anxiety than wonder when, a week after the journal's debut, she wrote to her aunt:

I hear there is a new paper comes out three times a week called the Tatler.... He resolves to put in all the stories of the town, warns the gentlemen and ladies to behave themselves well. He has given an earnest that he will perform his promise, for he put in the story of Lord Hinchinbrooke coming Thursday night drunk to the playhouse, in a sad pickle, and there railed against marriage in a strange manner. His title was not put in but there were spectators enow to tell everyone who it was."

Perhaps the periodical would have seemed less menacing to the Harleys at another time. In the spring of 1709 the Tories, more tense than usual, waited out their return to power with impatience.

Mrs. Manley waited with them, for she had since 1705 avowed their "generous principles." Even while she waited, she wasted no time in ferreting out the identity of Isaac Bickerstaff. Nor was the discovery difficult. Steele was ambivalent in his desire to move through the journal incognito. An anonymous author, he had been advised, could best fulfill the political hopes of the Tatler. Yet its instant success made self-effacement an affront. In a letter to Ambrose Philips, dated 26 April 1709 from the Cockpit, he confessed that he had been associated with the periodical, but even now was reluctant to reveal his authorship, falling back on an almost coy circumlocution. "This paper," he wrote, "extreamly prevaiis in Town and they do me the Favour to say I write it, I do not, but I will be so far a. Plagiary as to give you this way the Passages here in a more agreeable Manner than I otherwise could, therefore hope you will from time to time take it as a Letter from . . Rich ${ }^{a}$ Steele." Mrs. Manley always knew what the Town knew. Sensitive to Steele's 
politicizing, she feared that the Tatler, written with the know-how and convictions of the adamant Whig Gazetteer, might prick at Tory aspirations. As cunning as she was glib, she understood the strategic importance of initiating an attack, and The New Atalantis was her weapon. Since her quarrel with the essay serial was nourished only by suspicion, she did not bring up its title but stripped away from the once "wretched common "Trooper" any moral credibility and sense, whether he wrote as Gazetteer or Bickerstaff. She therefore intruded the speedily drafted picture of Monsieur le Ingrate upon her anecdotal narrative.

Other reasons prompted her to render Steele as a physically and spiritually blackened creature, an irresponsible grotesque. She herself-ever since the penny-poor summer of 1701-had been an unremitting Steelc-Watcher. She resented his minor triumphs, professional and marital. Forced by financial need to move from one man's bed to another, she would do violence to a one-time intimate who now flaunted his connubiality. Her personal prejudices, however, were seldom divorced from the political. As a consistent Tory she sneered at Steele's consistent Whiggism, particularly since his party loyalties, unlike hers, paid off in conviviality and employment. He was, she knew, a Kit-Cat; as Gazetteer he earned $f_{3} 300$ a year less a tax of $f_{2} 45$, surely enough moncy "to [be] well dress'd in agreeable Company." He had respectability while she-even to the sympathetic Swift-remained a woman of that "sort."

Her assault on Steele was precipitated by both a sense of personal grievance and an eagerness to do the Torics "some small service." Ulimately, however, she satirized him because he was such an easy mark. He was his own worst enemy, lending hirnself to the kind of portraiture at which she was adroit. $\mathrm{He}$ intimated his own perfection, moral and political; yet he was a spinning man, often given to pretense and hence a natural subject for ridicule. He sported the mannerisms of a Christian Hero, who-far from practicing virtue-publicly confessed his taste for good wine and willing women. He preached a work ethic while he pursued any get-rich-quick scheme. He extolled the worth of candor but in all likelihood had served as an informer for people as diverse as Lord Cutts in the Isle of Wight, John Ellis in Harwich, and the Junto in Prince George's bedroom. He advertised himself as a censorious and righteous person. whose severity was leavened by benevolence. So there he was, flawed as anyone else. For Mrs. Manley, and for successive critics, he epitomized the hypocrite, the "black beau" who coveted power, real wealth, and only apparent good. He was the ideal pharmakos, just waiting to be pinned to a paper by a satiric quill.

Her "representation," which is accusatory throughout, began in a vague present. She introduced her readers to Monsieur le Ingrate "(stuck up in a 
pert Chariot) thick-set, his Eyes lost in his Head, hanging Eye-brows, broad Face, and tailow Complexion." She then moved back to an equally vague past to "remember him almost tother Day." But whatever the tinne, the clominant impression stayed the same. He dissembled by instinct and need; "he cover'd all by a most profound Dissimulation." In an aneedote of Monsieur the alchemist the pencilled lines became a full-blown "painting" at once farcical and melodramatic, a compound of spleen and ridicule, which showed him as a gull bamboozed by an "illiterate" swindler and his innate greed. The portrait dramatized his instability and emphasized a man turned manic by dreams of gold or plunged downward by disappointment. Mrs. Manley's audience laughed at the fumbler-alchemist. But they were denied laughter when, pulled back into the present, they confronted the image of a swaggerer married to an heiress and able to spark it "in the Prado." "They were impelled by authorial tone to deplore injustice which elevated the unworthy and to judge not the person visible to the world but the tattered being under the fashionable apparel. Here was the claimant to virtue who sold out friendship and repaid generosity with meanness.

Anger and hurt-always controlled-animated Mrs. Manley's portrait of Steele. Through the piling up of details, each verifiable and each given a slight pejorative twist, she planned to damn him beyond the reach of human hope or, at least, to render him useless to the Whigs. But even as a dirty fighter she could not contain his resilience. The skirmish she initiated was to become a Ayting, a hit-and-run verbal exchange that ended only in 1717. What she succeeded in doing in May 1709 was to set a pattern for anti-Stcele cliatribe, a vituperatio hominis, that reached a scatological climax in 1713-14.

\section{if}

Even prior to its distribution, some people sensed the Tatlcr's party squint. In a letter to her husband, Lady Elizabeth Hervey reported: "T'his is all the news I know, except this inclosed paper, which I heard Lord Sun: commend mightily, so I have teazed Mr. Hopkins till he got it for me, for tis not published, tho' it is printed. Mr. Manruing and one or two more is named for the authors of it." From the beginning, then, the journal was linked with men unabashedly Whiggish. And those who expected a political statement from the Tatler were not kept dangling. In the fourth number Bickerstaft offered the parable of Felicia, an island in America equatable with Britain under the unspecified bur recognizable Godolphin ministry. The parable itself is as simple as most parables and constructed upon a hyperbolic slogan: a ministry 
of virtue, a leadership of excellence. Nor was this all. Before its second week ended, the journal had produced King Williarn as its special myth figure, who recalled the Revolution Principle, and Marlborough as its talismanic hero, who "has ascended to the cluaracter of a Prince." Not once did the term Whig emerge. Yet it hovered as an aura, embracing all of England's brave men, connoting social beatitude, and bringing to a grateful people the rewards of "prosperity," "happiness," "tranquility," "liberty"-glory words all. ${ }^{10}$

The Tories tracked the adventures of Isaac Bickerstaff, never an easy man to take sights on. Within a short time their ire was proportionate to their frustration. They did not need to wait for John Gay to learn that the Tatlcr was "so agreeable an amusement" that even "the Coffee-houscs began to be sensible that the Esquirc's Lucubrations alone had brought them more customers, than all their other News Papers put together." They also quickly saw that within "the vast variety of subjects which Mr. STEELE" handled there was political order ironically unpredictable both by the Tatler's author and his opposition. ${ }^{11}$

No one, in short, doubted Steele's commitment to party. But how and when Bickerstaft would express it stayed a mystery. Tory propagandists, ready to pounce, found themselves either caught unawares or with little room in which to maneuver. For eximple, they could not hit out against the Censor's description of himself: "I am very cautious not to hate a Stranger, or despise a poor Palatine." With this one sentence, which called up the biblical virtue of hospitality, Steele and his alter ego welcomed as many as ten thousand Protestant refugees, who in the late spring and summer of 1709 fled their Catholic persecutors. Within this one sentence also were applauded a Whig cause and the efforts of Wharton in settling a number of the exiles in Ireland. The constant reader of the Tatler, by now attuned to BickerstafT's technique of multi-layered speech, knew precisely what Steele meant, for-as one lady had put it-"The Case of the Palatines is all our domestic talk."1z

Tory propagandists could not in 1709 keep up with the transparent and altering fictions through which Steele implied but never stated his political values and affiliation. For instance, he translated a five-months-old controversy between the high-flying Ofspring Blackall, Bishop of Exeter, and the Whig clergyman Benjamin Hoadly into a bantering allegory. There he belittled the Bishop as a failed puppet master "who is himsele but a tall puppet, and has not brains enough to make even wood speak as it ought to do." Steele was to prolong through four essays the narrative of the anthoritarian puppeteer, whose "design is to have all men automata." But in each essay he undcrscored the 
insignificance of his villain for "his parts decay, and he is not much more alive Ulan Partridge," "1.3

The Tories could not second-guess the topics on which Steele chose to be expansive or those about which he decided to be tight-lipped. Why did he spend a seemingly inordinate amount of space and time on a negligible religiopolitical debate concerned with the issues of passive obedience and non-resistance ' Why, on the other hand, did he pass casually over the Sacheverell affair, a contretemps which provoked mobs of Londoners to cteate a new hero in clerical armor and to riot through the streets, all in the name of the Church? In three sheets-on 2,4, and 7 March 1710-Bickcrstaff smiled away the hullabaloo as a game intended to titillate bored ladies who, during the clergyman's trial, devoured "many cold chickens ... for the good of their country."14 Tory pamphleteers were more than confounded by Stecle's insouciant disregard for the most volatile incident of the decade; they were, in fact, verbally paralyzed by it. They could not retort to a smile or virtual silence. As a journalist Steele was slippery. It was just his agility in selection, his lightness of touch that helped him beat the Tories in a year when little or nothing downed them.

What infuriated them most about the Tatler were its news dispatches converted almost by sleight of hand into editorials. Certainly the trickery was there, but so also was a newsman's vision of reality. That is, Stecle exercised what he believed to be his prerogative of arranging and emphasizing details, of introducing new intelligences or omitting facts, all to creatc a fantasy and satisfy party hopes for a happy ending. Thus Bickerstaff reported the peace negotiations in 1709. He heralded them as a presage of the Pax Britannica and ultimately attributed their failure, on the alleged authority of the Marquis de Torcy, to the wilfulness of the French king. Left unsaid were the stalling tactics devised by the allied ambassadors at the peace conferences, the delays created by the Whig philosophy that peace was "to be argued sword in hand," and the objections manufactured within ministcrial sessions to satisfy English military leaders and City men who demanded a continuation of the war at any price. To minimize the disappointment of the English when the peace parleys collapsed and to distract attention from their failure, the Censor suppressed news about rising food prices and taxes at home-hardships traceable to the prolonged conflict-and instead discoursed at length and with condescension on French suffering. ${ }^{16}$

Such reporting threaded its slanted way through the Tatler. Talk about current events, however, became rare as the journal grew older. Readers must therefore have been surprised to see an account on 12 August 1710 of a battle, won by valiant English troops, on the plains of Balaguer. The battle itsclf was 
made secondary to what were presented as incontrovertible facts, exhilarating in their selfess humanity: the heroism of General Stanhope still weakened from "a dangerous and violent fever"; the noble deaths of the young Count Maurice of Nassau and the equally young Earl of Rochford, "both sons of persons who had a great place in the confidence of your late King William." This was brazenly biassed news "reporting." Its spirit at this time complemented Steele's relentless thrusts at the Tories, whose contagious lunacy demanded the construction of a New Bedlam with "the ambient seas" for its outer limits.

Steele himself blew new life into a paper war that until then had had little vitality. Tory pamphleteers had remained more still than not during the first year of the Tatler's life. Mrs. Manley, of course, refused to be silent. In October 1709 she found the journal's satire deficient. Its Horatian politesse, she charged, was only a cover for atthorial venality and every other non-value that sapped national "Greatness," "Virtue," and "Glory." Shortly thereafter a broadside, called simply The Character of the Tatler, was sold in the pamphlet shops. Much indebted to Mrs. Manley's highly vituperatjve criticism of Steele, it tried hard to pretend objectivity. It moved, therefore, between belittling gibes at Abednego Umbra, "Nego, as they us'd to call bim," and serious denunciations of the hireling propagandist. The biblical allusion mocked the amateur scientist who, unlike his namesake, emerged scorched from his own experimental furnace. Sirmultaneously the epithet reduccd the self-styled moralist to a scribbling fake. For the first time too the Tatler's factionalism was documented, its editorial reliance upon "a limited number of Performers, called Directors"--perhaps Sunderland, Mainwaring, Addisonwho "obliged themselves to call every Thing by a Wrong Name, take every Thing in a Wrong Sense, and put False, and Rude, New and Unheard-of, Interpretations upon Nature, Manners, and Religion." Eager to scatter the Tatler's audience, the broadside castigated the periodical for playing at literature and hiding its grubby identity as an adjunct of party. ${ }^{18}$

Attacks like these were too sporadic to affect Steele or his paper adversely. In August 1710, however, the Tories decided that they needed no longer observe rules of journalistic discretion. The Godolphin ministry had fallen; a Whig defeat in the Parliamentary election scheduled for autumn seemed a certainty. The Examiner had been launched. And Harley, made contemptible by Bickerstaff as the deceitful Hanno and the meddling Polypragmon, was vengeful enough to spend thousands of pounds on the attempted destruction of Stcele's periodical. Obedient to the Tory leadership, the Examiner in its fifth number declared open war on its formidable rival. The campaign began by concentrating on the Tatler's news coverage generally and isolating the 
report of the battle of Balaguer for specific disparagement. With the insinuation, "We had lately News of a great Action in. Spain. where for some Years the War has been carry'd on very calmly," the Tory persona accused Steelc of fabricating current events or exaggerating their importance to gloss over the real fact of a vanquished ministry. But this was a Whiggish sin that the Examiner's mask professed to understand and even tolerate. What was deplorable, however, was Steele's explotation of his official position as Gazetteer to enhance his private aspirations and those of his party.

Abandoning insinuation for the techrique of mock-aesthetic scriousness, the Examiner set up parallel columns in which statements describing the battlc of Balaguer were drawn from the Tatler and the London Gazette. The columnar structure made the selection of passages gleam with malice. The choice was limited to those in which word order alone changed. Wich slow-paced deliberation the Tory persona studied his tables and repudiated the "Judgment of Longinus, and the rest of the Greek Critics, who would persuade us, that after a correct Writer has adjusted the due Order of his Words, there can be no Change of "em but for the worse." As the persona's banter continued, he claimed for himself the virtue of fair-mindedness. Unlike those who deferred unthinkingly to rule-givers, he saw no substantive or creative dificrence between the Lucubrations and the Gazette, no falling off one from the other. On the contrary. Because the two journals were aborted from a single malodorous identity, their authors in self-defense-so the persona assumed"move together in an annicable Way, Hand in Hand, and like the Two Kings in the Rehearsal, smell to the same Nosegay."

The tone of the Examiner for 24-31 August 1710 varied as its propaganda methods changed. There was ironical insinuation, fertile in what it never stated; there was the wit of mock-intellectuality. But as the essay neared a climax, the game was over and the laughter stilled. The tone was now one of anger as the mask isolated yet another journalistic sin that emanated from St. James's Coffee House, specifically the introduction of calculated irrelevancies for party purpose. "Why are [Stanhope's] Politicks brought in upon this Occasion? What have Notions of Government to do with Conduct and Courage in the Field?" The questions piled up through two paragraphs. But the Examiner, its timing precise, shifted suddenly to simple declarative sentences and pointed out with stern factuality the Tatter's insensitive Whiggism in yoking the deaths of two heroic young men to their fathers' association with King Willian. Steele's journal stood accused of making political capital out of what should have been cause for genuine grief.

So sure was the Examiner in its revelation of the Tatler as a propaganda 
vehicle, its dedication to party rote-like, that the mask ended with a warning to Bickerstaff, who was presumably so flayed at this moment that he had little option but to cower and hide himself.

My Advice to you is only this, That you wou'd still appear in your proper Sphere; and not quit a Character which has giv'n you some Credit, to take up another that does not in the least become you. Give me leave to tell you, you mistake your Talent, whenever you meddle with Matters of State; your Jest pleases no Body, when it reflects upon the Constitution, under which you live... Begin to take care of your self; remember the fate of one of your Predecessors, and don't gaze at Your Stars, till you fall into a Ditch. No more of your Politich Lucubrations; put out your Candle; favour your Age; and go to Bed sooner. ${ }^{10}$

If the threat hinted tonally at the satiric iocularia, it was nonetheless a threat that concealed within itself the full weight of the party in power. And the threat, variable only in degree and statement, suffered repetition ad nauseam in the ncxt few years, ending with Steele's Parliamentary humiliation in March 1714.

In August 1710 Steele did not defend either himself or his paper's Whiggism. A friend, however, put on the caligatus appropriate to a satirist and strode across the streets of London to vindicate a Bickerstaff already limned by the Examiner as an "unexpert Conjurer, who raises a Spirit that he has not Skill enough to lay" or as "the Famous Censor of Rome... espousing the Cause of the Vanquisly'd." Less detached than usual, Addison derided the Tatler's newest enemy with imagery evocative of pestilential filth, of parasitic vermin, and scavenging animals. Whatever the force of his attack, the Tory periodical had scored. In scant time it accomplished what it intended from the first. It forced a match with the Tatler, which-even Whigs agreed-"had given Offence . . . by some smart Strokes" laid upon Tory leaders. In its response the Examiner was cither ignorant of or indifferent to Addison's authorship; certainly it refused to lose sight of Steete as an already staked-out quarry and the prototype of Whig "libellers" everywhere.

The Examiner for 5-12 October maintained a balance, stalking the man through scarifying allusions and the political writer through controlled diminution. The man of the Town was vain, a laughable "lucubrating Fop:" whose prodigality and irresponsible behavior made the "Spunging-house" inevitable. Like the man, the essayist enjoyed a pretentious self-delusion and forgot that he was but a "Retailer of loose Papers, one of which is still dying before the next is born." Linked to the man and the essaysst was the propa- 
gandist who-according to this eleventh issue of the Examiner-could "scorch nothing but Turkies and Capons." The function of the essay was clear-cut. It denied validity to both the human being and the journalist, whose "Itch of being very Abusive is almost inseparable from Vain-Glory" and whose desire to be and write "something Extraordinary" is so compulsive that he "scarce knows what he would be." This Examiner made a palpable hit. It was also, as Addison later accused, very much like a mechanized character assassin, an executioner bent upon the eradication of Stcele and of all those who questioned Tory doctrine..$^{3 \mathrm{x}}$

With the formation of the Harley-St. John ministry and the Parliamentary overturn in which 270 Whigs lost their seats and an awesome Tory majority governed in their stead, other journalists moved in against Steele. They followed an established line of attack, begun by Mrs. Manley and refined by the Examiner. To one Whig observer, the pattern was to "Build Scandal on Fiction, and assert boldly and abusively without Shame or Conscience." More particularly, the pattern fixed on Steele for its conspicuous mark, proposing to excoriate the man in order to discredit his political writing. It was a technique of ad hominen criticism explained by several Tory propagandists but rone with greater perception than Swift, who had proved its efficacy as early as 1708 , paradoxically in a work he put aside and never finished. In that year his victim was Tindall and his dejstic Rights of the Christian Church. Both the author and his book, Swift argued, needed to be anathematized into non-being. And he hoped his mission was sacred enough to justify the method and give it a rationale. "For, although a Book is not intrinsically much better or worse, according to the Stature or Complexion of the Author, yet when it happens to make a Noise, we are apt and curious, as in other noises, to look about from when it cometh. ${ }^{22}$ The psychology of such criticism is basic. It satisfies a natural curiosity about other people and scandal; it fulfills a communal need for a scapegoat; it elimirates at one and the same time the individual, who annoyed, and his ideas, which annoyed still more.

In a jingling ballad called The Loyal Calves-Head-Club, the Tatler was defined as the mouth-piece of the Kit-Cats, "Hard-mouthed Sots" motivated by Cromwellian principles to desecrate "the Church and Crown" and, conversely, to "advance their Canting State" by any villainous lic and foul "Plot." Such assaults, more concerned with the periodical than with who wrote it, nonethcless encouraged other statements that inveighed against its author. The two-pronged attack joined together in a single purpose, to assert the judginent that the man and his work must be thrust aside as alternately silly and foul. In September 1710, as an example, $A$ Condoling Letter to the Tatler berated 
the satirist with familiar epithcts: Steele the spendthrift, Steele the hypocrite, Steele the swaggerer, Steele the inmate of a sponging-house. Relying then on a parody of the Tatler's "State Weather-glass," the letter-writer created his own engine, an "Oeconomical Barometer," by whose lines of ascent and descent Steele-upwards and downwards-emerged always as a madman whose selfwrought lunacy could be neither condoned nor condoled."i

The brutality of the paper war left him undiminished; his psyche had mysterious ways of restoring its balance. He continued to laugh at those who attributed his political essays "to a bartenness of invention" or a paucity "of matter." He felt no need to alter his style or his material, wearing his politics with an air of virtue and simple goodness. Armed as he said he was with Ithuriel's spear-a weapon of "celestial temper"-he discarded any notion of capitulation. He held out, loyal to a lost cause because he knew it to be a right cause and because he knew that sooner rather than later he would be bought off by his attackers. ${ }^{24}$

His was a crass innocence. A probable virtue for a party journalist, it brought him to the bargaining table with Harley-possibly as early as the first few days in October 1710 -after which Steele promised the death of his journal in exchange for retaining his post in the Stamp Office. It therefore made no real difference to him that the Tory Moderator under the date of 3 October reported or leaked or predicted the newsworthy event that "This day the Ingenious Isaac Bickerstaffe, Esq; late Censor of Great Britain departed this Life at his own Apartment in Sheer-lane, much lamented by the Gentlemen of the Kit-Kat-Club and all true Republican Spirits, for his hearty zeal to the good old Cause, his universal Learning, and particular Skill in the Laws of the Land." Nor was Steele's way of life in any way incommoded by the first number of the Friendly Couriere which on 2 January celebrated the demise of the Tatler on that very day. What mattered to Steele was that he himself was liberated from Isaac Bickerstaff. With renewed vitality, he took off an altogether too familiar mask and tried on others, unknown and obscure. He relished a rare sense of safety early in 1711 as le continued to harass the Lord Treasurer and those other "hated Ministers with his Pen, under other Names, when be did not think fit to make use of his own" or the Stamp Commissioner's. ${ }^{20}$

His crassness had usually to do with financial necessity, "employment" and a compulsion to double-deal those he held in political contempt. His innocence, on the other hand, prompted him at this time to express unquestioning loyalty and gratitude toward anyone who wrote a kind word on his behalf. When Lord Cowper, for example, acknowledged "that cxcellent Genius" bestowed 
gandist who--according to this eleventh issue of the Examiner-could "scorch nothing but Turkies and Capons." The function of the essay was clear-cut. It denied validity to both the human being and the journalist, whosc "Itch of being very Abusive is almost inseparable from Vain "Glory" and whose desire to be and write "something Extraordinary" is so compulsive that he "scarce knows what he would be." This Examiner made a palpable hit. It was also, as Addison later accused, very much like a mechanized character assassin, an executioner bent upon the eradication of Steele and of all those who questioned Tory doctrine. ${ }^{21}$

With the formation of the Harley-St. Joln ministry and the Parliamentary overturn in which 270 Whigs lost their seats and an awesome Tory majority governed in their stead, other journalists moved in against Steele. They followed an established line of attack, begun by Mrs. Manley and refined by the Examiner. To one Whig observer, the pattern was to "Build Scandal on Fiction, and assert boldly and abusively without Shame or Conscience." More particularly, the pattern fixed on Steele for its conspicuous mark, proposing to excoriate the man in order to discredit his political writing. It was a technique of ad hominen criticism explained by several Tory propagandists but none with greater perception than Swift, who had proved its efficacy as early as 1708 , paradoxically in a work he put aside and never finished. In that year his victim was Tindall and his deistic Rights of the Christian Church. Both the author and his book, Swift argucd, needed to be anathematized into non-being. And he hoped his mission was sacred enough to justify the method and give it a rationale. "For, although a Book is not intrinsically much better or worse, according to the Stature or Complexion of the Author, yet when it happens to make a Noise, we are apt and curious, as in other noises, to look about from when it cometh." The psychology of such criticism is basic. It satisfies a natural curiosity about other people and scandal; it fulfills a communal need for a scapegoat; it eliminates at one and the same time the individual, who annoyed, and his ideas, which annoycd still more.

In a jingling ballad called The Loyal Calves-Head-Club, the Tatler was defined as the mouth-piece of the Kit-Cats, "Hard-mouthed Sots" motivated by Cromwellian principles to desecrate "the Clutrch and Crown" and, conversely, to "advance their Canting State" by any villainous lie and foul "Plot." Such assaults, more concerned with the periodical than with who wrote it, nonctheless encouraged other statements that inveighed against its author. The two-pronged attack joined together in a single purpose, to assert the judgment that the man and his work must be thrust aside as alternately silly and foul. In September 1710, as an example, $A$ Condoling Letter to the Tatler berated 
the satirist with familiar epithets: Steele the spendthrift, Stecle the hypocrite, Steele the swaggerer, Steele the inmate of a sponging-house. Relying then on a parody of the Tatler's "State Weather-glass," the letter-writer created his own engine, an "Oeconomical Barometer," by whose lines of ascent and descent Steele-upwards and downwards--emerged always as a madman whose selfwrought lunacy could be neither condoned nor condoled. ${ }^{23}$

The brutality of the paper war left him undiminished; his psyche had mysterious ways of testoring its balance. He continued to laugh at those who atributed his political essays "to a barrenness of invention" or a paucity "of matter." He felt no need to alter his style or his material, wearing his politics with an air of virtue and simple goodness. Armed as he said he was with Ithuriel's spear-a weapon of "celestial temper"-he discarded any notion of capitulation. He held out, loyal to a lost cause because he knew it to be a right catse and because he knew that sooner rather than later he would be bought off by his attackers. ${ }^{\text {. }}$

His was a crass innocence. A probable virtue for a party journalist, it brought him to the bargaining table with Harley-possibly as early as the first few days in October 1710-after which Steele promised the death of his journal in exchange for retaining his post in the Stamp Office. It therefore made no real difference to him that the Tory Moderator under the date of 3 October reported or Ieaked or predicted the newsworthy event that "This day the Ingenious Isaac Bickerstaffe, Esq; late Censor of Great Britain departed this Life at his own Apartment in Sheer-lane, much lamented by the Gentlemen of the Kit-Kat-Club and all true Repmblican Spirits, for his hearty zeal to the good old Cause, his universal Learning, and particular Skill in the Laws of the Land." Nor was Steele's way of life in any way incommoded by the first number of the Friendly Couriere which on 2 January celebrated the demise of the Tatler on that very day. ${ }^{25}$. What mattered to Steele was that he himself was liberated from Isaac Bickerstaff. With renewed vitality, he took off an altogether too farmiliar mask and tried on others, unknown and obscure. He relished a rare sense of safety early in 1711 as he continued to harass the Lord Treasurer and those other "hated Ministers with his Pen, under other Names, when he did not think fit to make use of his own" or the Stamp Commissioner's. ${ }^{26}$

His crassness had usually to do with financial necessity, "employment" and a compulsion to double-deal thase he held in political contempt. His innocence, on the other hand, prompted him at this time to express unquestioning loyalty and gratitude toward anyone who wrote a kind word on his behalf. When Lord Cowper, for example, acknowledged "that excellent Genius" bestowed 
upon Steele by heaven and praised him for proving with wit that "Honesty and Pleasure are inseparable," the erstwhile Bickerstaff responded by dedicating the third volume of the collected Tatlor to him in April 1711. More than that, he addressed his Lordsbip as one who spent himself in "defending the brave and unfortunate." Steele, even when genuinely moved and almost off-stage, never lost sight of his oratorical role, that of the courageous victim despised for his dedication to truth. And it was this role that he needed to develop during the turbulent years that he saw lying ahcad of him and his party.

The Spectatorial days between March 1711 and December 1712 were almost irenic for Steele, peace for a restless and impatient spirit being a matter of degree. But during that interlude he did not quite disappear as a target. The Tories never wrote him off as a menace, never assumed that he could be silenced for Jong. They doubted the non-political intention of the Spectator just because he was associated with it. Their suspicions were confirmed with the third number when the essayist-in this case Addison-anticipated the Whig-Tory struggle in April $171 \mathrm{I}$ for the control of the Bank of England. Through an obvious dream allegory whose threatened heroine was Public Credit, he implied what Whigs everywhere were saying, that the national economy could not survive either Tory manipulation or the absolutist succession that the ministry would effect once their adherents ruled the kingdom's wealth.

Ministry writers wasted no time, In early Apri] Mr. Spectator was warned in a pamphlet-as Bickerstaff had been warmed-that he was being watched, investigated, and indeed "spied" upon. The pamphleteer saw in his new opponent a familiar "Magisterial Authoricy" reminiscent of a former censor. "And perhaps he shall shortly find, he has not Art enough to disguise himself; and that a Net is too thin a Cloak for a Party-Man to dance in." Almost as if in deliberative reply, the Spectator used one of its papers on false wit to decry bad taste and to assert its political independence one mote time. "If we must Lash one another, let it be with the manly Strokes of Wit and Satyr . . . if I must suffer from one or the other-1 would rather it should be from the Paw of a Lion, than the Hoof of an Ass. I do not speak this out of any Spirit of Party," insisted Mr. Spectator " "There is a most crying Dulness on both sides."

Similar statements of non-partisanship were scattered throughout the essay serial. Certainly they were not believed, but they did restrain the forays of those whom Addison had dubbed "dirty Scriblers." In May 1712, however, the uneasy peace was momentarily shattered when Steele uscd most of one number for a reprint of Fleetwood's Whiggish Preface to his Four Sermons. Tory journalists challenged with speed. The rencounter was initiated by William Wagstaffe in the Plain Dealer, which within three days-on 24 May-hooted 
at the Spectator's boast of political impartiality and mocked Steele as Dick Hotspur, a rash villain of "ill principles" and a projector of republican adventures. The Examiner also added to the clamor. But the big guns appeared two months later in a Swiftian pampllet which mentioned neither Addison nor Steele but laughed at their paper as only one of a factional "Fraternity," a "Dealer in Words," and a purveyor of Whiggish nonsense."

To a paper as powerful as the Spectator, such attacks were superficial. So too was the one in November, just before the end of the first scries. Bickerstaff, buried now for almost a year, was exhumed by Harley's journalists. This time Steele was pummelled in couplets. If nothing else, The British Censor proved Mr. Spectator's earlier generalization that "when Dulness is lodged in a Person of quick Animal Life, it gencrally cxerts it self in Poetry." The old chargesSteele's rashness and irresponsibjlity-reappeared through indecent innuendo.

Once a Cadet, obscure and little known

(Now such a bright conspicuous Wonder grown)

His springing Parts he ventures to expose,

To thoughtless Bullets, and to blund'ring Foes,

His stupidity was traced back to failed experiments in alchemy, "his Sence in Part dissolv'd in Smoke." His hypocrisy had no external source; it was simply part of a personality which corrected "all Men's Manners, not his own." The poetizer recognized that old complaints could carry him just so far. But because they had been so frequently repeated, they created a farniliar milieu for a new accusation. What was daring about The British Censor was its image of Steele as a journalistic Maecenas.

But Thou more mighty than these mighty Dead,

Art Wit's, art Learning's, universal Head.

Like Rome's chief Prelate do'st thy Lords dispence,

Like Hin extorting blind Obedience;

And seem'st thy Self unerring to believe,

Flush'd with the dull Regard that Bigots give.

Here was a precursor of the "Little Senate" over which presided not Addison but Stecle, who ironically never commanded any authority except through a fiction or a real sacrifice of self. ${ }^{\text {an }}$

\section{III}

In November Steele was anesthetized against the sting of The British Censor; too many other things were happening. Arthur Mainwaring had just 
died. Addison took his place as the unofficial director of Whig propaganda, recruiting a journalistic tribe, feeding them information and a point of view, rewarding those who had tested thejr gift of persuasion or assault in periodical and pamphlet. As long ago as 1709 Addison had been made aware that few were journalistically more gifted than Steele. His Whiggish ideas, worn with a political religiosity, were never clandestine in intention. Their statement was pleasing, assimilable through smooth implication and narrative. At the same time he was aggressive in demolishing the arguments of the Opposition, for he had many of the arts, freed of over-nice scruples, that belonged to the trained rhetorician. His commitment to party was almost instinctive, its animalism softening the edge of his cleverness. He had for at least three years exhibited a beguiling hardness that had more to do witl simple loyalty and resilience than with a ruthlessness that could offend. He was a compelling man because he seemed surrounded by a centripetal eddy of emotion, self-created. If Addison, as liaison between the Junto and party writers, had his way, Steele would become "a Brother-Scribler," the most visible of Whig propagandists. And Addison had his way.

In less than a year Steele became virtually a one-man answerer to Mrs. Manley, Oldisforth, Defoe, Swift, Arbuthnot, and a number of anonymous Tory writers. The odds appeared to be not in his favor, but he was ready to gamble. He knew and believed in what he had to do. He was hardly a novice at political infighting; he enjoyed its excitement and in return accepted its uncertain consequences. To one as sanguine as he, there always remained the "expectation" that the great men of the party would be liberally grateful. In time Whig generosity- $\_3,000$ worth-proved to be "beyond [his] expectation." In an cxultant note to Prue on 25 March 1714, a week after his expulsion from the Commons, he wrote: "All I hear now is this morning from Amburst, that 30001 . is to be paid in to Mr. Warner for my Use, but when, and by what hand I am still in the Dark. . . God will preserve Us, and let us meet with Joy."

The amount of money was substantial but Steele worked hard and endured much for it. By early spring 1713 he refined his finger-exercises with the pamphlet form when he wrote $A$ Letter to Sir $M$. W. concerning Occasional Peers. In June he gave up his commissionership in the Stamp Office and his employment as gentleman-usher to the late husband of the Queen. He permitted himself to be put up for the Commons. By August he was ready to serve the Whigs as a pamphleteer and Member of Parliament, to function as their chief propagandist with a single goal. And the goal was not covert, According to one opponent, "he does not question overturning the Ministry, 
and doing that before the first Sessions of Parliament is over, which tny Lord Wh-on and $S-r s$ have been foll'd at, for Three Years together. ${ }^{, 32}$. What the Tory-perhaps William Wagstaffe-underestimated was the length of time Stecle demanded for himself, for no one was better attuned than he to the complexity and onerousness of the task assigned him.

Because he represented the party of Outs, he had to reject many of the devices and moods that shaped the early political essays of the Tatler. He had to abandon easy-paced humor, the indirection of dream visions and parables, the gentility of tolerant satire. He had now to give violence for violence, to initiate aggressive action, and to pursue every counter-attack. His pamphlets and certain of his periodical essays became necessarily articulate statements that "pointed with alarm" to ministerial ineptness while they insinuated a ministerial deceit that threatened the safety of every Englishman. They suggested, dramatized, or narrated-according to need-a struggle between a suppressed mass of patriots and a handful of powerful men, ready to sell out their queen and country.

Behind the stridency of his journalism and its apparent cockiness lay precision in planning. He acknowledged in practice that certain subjects were taboo and that substantive circumlocutions had therefore to be found for them. When, for example, peace became a fact at Utrecht in April 1713, public joy was so vociferous that the Whig inner council decided to be mute. At this point their reaction was a shrug-of-the-shoulder quiescence. Berkeley, who dined with several Whigs at Dr. Garth's house on the day the armistice was announced, found that "they had not the heart to speak one word against the peace. Indeed the spirit of the Whigs seem quite broken." However, Betkeley misinterpreted their behavior, ignorant that such silence was a tactic in all likelihood spelled out by Lord Somers as early as $1711^{\text {sa }}$ The Junto leader recommended to the party faithful and especially to its propagandists that the peace be accepted with taciturnity and that several of the conditions and articles of implementation be condemned but only after the signing of the treaties at Utrecht.

Those who contributed to the Examiner were not unaware of the Whig scheme; they had after all heard the din generated over the free-trade articles, a din responsible for the first major Tory defeat in three years. But the quiet of the summer months in 1713 had a near-pacific effect even on the Examiner; its essayists were momentarily lulled and almost indifferent to the "CoffeeHouse Orators, now in Service of the Whigs and some of their Puny Writers." On the day Guardian 128 appented, the Tory periodical grudgingly held forth a tentative olive brancl, for "All these frightful Symptoms of a bloody Paper- 
War are entirely vanislid." On 7 August therefore Stecle aroused his Tory stalkers with the first of his new probes against the ministry. ${ }^{34}$

In Guardian No. 128 he challenged neither the desire for peace nor the cessation of warfare. But behind the mask of Nestor Ironside and a letter writer named English Tory, he called attention to one of the conditions of the peace stipulated in April by Her Majesty's government and agreed to by the French. What Steele had in mind and what Englisl Tory detailed was "that within three Months after the signing of the Peace, the Works toward the Sea [the port facilities in Dunkirk], were to be demolished, and within three Months after it the Works toward the land [the fortifications of the city]." The entire essay is built upon a single slogan, "that the British Nation expect the immediate Demolition" of Dunkirk. The arguments are negligible; the slogan, restated and refined, is all-important and pointed by its simplicity. What is insinuated is a question: why have these Works not been razed by ministerial order when British trade has been endangered by privateers riding out of Dunkirk harbor for more than half a century, when "the Pretender sailed from thence to Scotland" in 1708? The question having been implanted in the heart of the essay, English Tory concluded with the slogan, presumably strengthened by group support and now emboldened by the force of incremental repetition: "That the Demolition of Dunkirk will remove France many hundred Miles further off from us... That the British Nation expects the Demolition of Dunkirk."

Tory rebuttal came swiftly in the Examiner, which dismissed Steele as an "Ingrate" and a "contemptible Wretch," his position as a "Lye" and a "Libel." It came even sooner in a pamphlet written by Defoe. That he had been chosen to respond to Guardian No. 128 was a testimonial to the essay's power to manipulate traditional English distrust of France, to its ability to unnerve the ministry with a slogan and a silent question. Assuming the identity of a country Whig, Defoe in The Honour and Prerogative of the Queen's Majesty Vindicated hoped for a tone of engaging candor: 'I rueddle not with the Question it self, Whether Dunkitk shall be demolished or no?"as Indeed, he dared not "meddle" lest he become involved in half-answers that would only provoke further questions about Tory responsibility. Thus constrained, he designed his pamphlet as a twenty-three-page diatribe against Steele, the man who was a "traytor," a "renegade," a "counterfeit," and a "bully." Much of the abuse was stale although some was updated. Steele, the raftish prodigal, soughtt election to the Commons-wrote Defoe's mask-only to secure himself against "just Debts." Still borrowing from his predecessors, the Tory journalist pictured Steele in 1713 as a Judas who had enlarged the range of his customary 
ingratitude to howl against an entire government and "the best of Sovereigns, the best Mistress to him, whose Bread he has eaten, and who has kept him from a Gaol."

$\mathrm{New}$ to this diatribe was Tory eagerness to lay bare the motivation for Guardian No. 128, its author's Whiggish hostility to the peace and the men who engineered it. New too was the side-swiping charge that Steele's reputation as an essayist was fraudulent, "That the greatest part of the Wit and Humour" found in the Guardian and the two earlier periodicals "was not [his] own." And hinted at for the first time in The Honour and Prerogative of the Queen's Majesty Vindicated was the offense that would result in Steele's expulsion from the House. Undoubtedly aware that the ministry had already determincd to drive him out of Parliament, Defoe carefully avoided the word sedition. Instead he attributed to Stecle a pcrverse need "to assault the Ministry" and "to attack the Queen's Person with Indecencies and unoutiful Bchaviour."

Defoe's piece was studied with avidity by the anonymous author of $A$ Second Whigg-Letter from William Prynne to Nestor Ironside," who apparently drew from it a single statcment on which he built his entire fiction: "The Tories," Defoe's persona had written, "indeed used to upbraid us [Whigs] with being Turbulent, Unensy under Government, of Commonwealth Principles." Now the new eidolon, William Prynne, seemed to emerge as if by signal from these plurases as spokesman for assortcd puritan regicides and republicans in hell who embraced common political vices, monumental ingratitude, and a fiery abode, and who also shared an obsequious capacity to anticipate "with Pleasure, what we may expect from one who durst, in the GUARDIAN, threaten the Queen, with an Air of assurance, That if Dunkirk were not demolish'd, she might expect-. "The sentence, which distorted Steele's slogan, was left unfinished to excite readers to fill in the elongated dash with horrific images of their own choosing. As a political lampoon, $A$ Second $W / h i g g$-Letter had minimal value. Its strength lay in its heavy-footed dramatization of Defoe's innuendo, that Stecle's writing tended to sedition.

Addison, tongue-in-check, chided the Examiner and by extension all other writers who "found out Treason in the word Expect."37 Steele himself gave no presumptive evidence of being perturbed by the vendetta against him. Perhaps he was still caught up in a drcam of himself as a big man in a mighty landscape. Perhaps he was exhilarated by the high spirits of his party. In the summer and early autumn of 1713 the Whigs had definite advantages. By defeating the eighth and ninth free-tradic articles of the commercial Treaty of Utrecht they demonstrated the popularity of their mercantilist posture. They were alert to the split between Harley and St. John, sporting their still relatively new tirles 
of Oxford and Bolingbroke. The Queen obviously had not long to live. The Whig road to the ministry lay straight alead. Party policy makers, therefore, continued to exploit the irresponsibility of the Tory leadcrship in its treatment of Dunkirk, to tie that issue to the threat of the Pretender, to underscore the choice between James Stuart and George of Hanover, and to insinuate that the Tories-not all, but many-were covert Jacobites. All this verbal prestidigitation the Whigs demanded of their propagandists and Steele did it all.

He did not back away from Guardian No. 128. He had through his personae lived a moral dictatorship for so long that he now accepted it as his prerogative. He had indeed achieved in print, as Swift was to sneer, "a sublime pitch of Virtue." In September 1713 Steele felt pin-pricked but very nearly invulnerable. In The Importance of Dunkirk Consider'd, published on the 22nd of that month, he reprinted Guardian No. 128 and expanded its body of debate by answering each point in the proposal written by Sieur 'Tugghe, that "nauseous memorialist," with statistics and "Hydrography."

Impudently he cited several Tory pamphlets, which he turned-or so he teased-to his advantage "by quoting them at large, and by that means swelling the volume to 1s. price." More than that, he transformed them, their scurrility uncensored, into so much evidence that he was now a person. Addressing himself to the "Worshipful Mr. John Snow, Bailiff of Stockbridge," Steele boasted: "According to my Promise when I took my Leave of you, I send you all the Pamphlets and Papers which have been Printed since the Dissolution of the last Parliament; among these you will find your Humble Servant no small Man but spoken of more than once in Print: You will find I take up whole Pages in the Examiner, and that there is a little Pamphlet written wholly upon $\mathrm{me}$, and directed to me." ${ }^{39}$ Like the mocking dedication which was meant to irritate his enemies, so the conclusion of The Importance of Dunkirk Consider'd aimed to taunt them. In the last pages of the pamphlet he burst forth with a typical appeal to benevolence and good will as the antidote to faction and political chicanery. It was an ending which, he $\mathrm{kncw}$, would anger the opposition because they dared not contradict it. So he strutted as the antithesis of that "poor Creature who cannot bear being odious in the Service of Virtue." Why should he not make a "Reasonable Sacrifice" of himself, he asked with humble effrontery, for "the highest Pleasure of the Human Soul consists in [social] Charity, and there is no way of making it so diffusive, as by contending for Liberty."

Allowing the Tories little time for a rejoinder, he dangled before them a new provocation. He brought forth the blatantly Whig periodical, the Englishman, on 6 October and on the 22nd of the same month advertised The Crisis, 
an effort of such magnitude that it was to be printed by subscription. The Tories were forced to meet his challenge: they had to respond once more to the Dunkirk documents, answer the opening numbers of the Englishman, and anticipate The Crisis. From the middle of October through the rest of the year-as Steele later recalled the experience-he "drew upon hirnself the Anger of all the Courtly Writers, at the head of whom is deservedly placed" the Examiner. Of these various "Courtly Writers," not one of whom evinced a verbal courtliness, it was primarily the author of $A$ Dialogue Between $A$. and $B$. who threatened him with legal sanctions. The others were not above hinting darkly at "Petitions" but for the most part they tried for the Whig's annihilation through varjed tones of ridicule. ${ }^{\text {to }}$

Steele had long wanted to draw Tory blood, and he did so with the program essay of the Englishman. The first number denounced the Examiner not for its own sake--that had already been done many times-but as an obscene vehicle of the Lord Treasurer, supported and encouraged by him to befoul a man who tried "to rouze in this divided Nation that lost Thing called Publick Spirit." Englishman No. 1 continued the Tatler's quarrel with Harley. In the earlier periodical the gibes had been softened, the target disguised behind the archetype of a politician masquerading as a statesman. Now, however, the gibes sounded harsh and every crime attributed to the Examiner was compounded by "him that keeps him." Through Steele's web of insinuation, Harley was trapped as a man "of power," paradoxically Himsy for want of wit and understanding. His filth required concealment and his malice the words of hacks.

In little more than a week the Dialogue Betucen $A$. and B. was printed and sent to the pamphlet shops. ${ }^{\text {t1 }}$ It purported to be a socratic exchange; it was in fact an attack upon Steele, one that pulled no stops. It associated him with hereditary madness, specifically that of his sister-"a fine Woman of his Family"-and prophesied his end "not, as some have thought formerly, in a GAOL, but in BEDLAM." The Dialogue vindicated Harley by pretending that the great man described in Englishman $\mathrm{No} 1$ was non-existent, that he was the fiction of one who in supposing "every Thing ... can be said to suppose really Nothing." The Dialogue branded Steele a traitor, a hireling Dutchman, who planned "Sedition for a Faction." Mr. B.'s raillery was held together by a thread which promised vague disciplinary action, vague because "no Punishment had ever been assigned for Sedition, for none but weak Men are guilty of it, in their publick Writings."

Within this pamphlet the charge of sedition was argued with a singleminded persistence that outdid innuendo, metaphor, and even the Examiner's 
flailing attack, and it could not be taken lightly. Having been advised by Addison and other friends "that his zeal for the public" tnight indeed "be ruinous to himself," Steele had sent them word that he was "determined to go on." Almost at once he felt the factitious energy that comes from having decided, regardless of consequences, on a course of action. He therefore stayed on as a fighting journalist, talking of issues he deemed crucial while laying an "Odium" upon the Tory ministry with "Insuendo's." He made himself felt because he wrote the Englishman relentessly, and just as telentlessly he made it appear three times a week. Against a quasi-philosophical background involved with the origin of government, civil rights in a contractual socicty, and the limits of the royal perogative, the journal hacked away at the Examiner and the ministry; it offered up Oxford as a sacrifice. As in epideictic oratory anywhere, it alternated between condemnation and praise. It gave itself: over to adulation of Godolphin and Marlborough, both presented as heroes fallen before the vagaries of political taste; it voiced every Whig principle as if it were a shibboleth vindicated by national consensus.

The Dialogue between $A$. and $B$., as we have already seen, was failed propaganda because it was snide without wit, serious without persuasive commitment. Its truculent sobriety antagonized readers. The Tory leadership, probably in concert with Swift, urged its writers to pursue the line of nonargument first conceived by Defoe but to enliven its vituperatio Chalybis with humor, to hone its wit on Steele. An anused audience had necessarily to be more congenial than one blasted by invective camouflaged as political high seriousness. The pamphleteers, who now dogged Steele, understood the craft of cruel laughter. They were cunning men able to repeat after Juvenal: nec pudor obstabit.

Switt, for example, began The Importance of the Guardian Considered by precluding any discussion of the Dunkirk issue.": It did not exist as a diplo matic matter, he asserted, but as one contrived by Whig ambitions and Stcele's hunger for self-aggrandizement. The tone of Swift's pamphlet was that of a gentle snigger and it was set in the preface.

Mr. Steele in his Letter to the Bailiff of Stockbridge has given us leave to treat him as we think fit, as he is our Brother-Scribler; but not to attack him as an honest Man. That is to say, he aliows us to be his Criticks, but not his Answerers; and he is altogether in the right, for there is in his Letter much to be Criticized, and litcle to be Answered. The Situation and Importance of Dunkirk arc pretty well known, Monsieur Tugghe's Memorial, published and handed about by the Whigs, is allowed to be a very Trifling Paper: And as to the immediate Demolish- 
ment of that Town, $M r$. Steele pretends to offer no other Argument but the Expectations of the Peoplc, which is a figurative Speech, naming the tenth Part for the whole. ...

What followed was an exercise in irony, Swift "partly as a Critick, and partly as a Commentator" considering his "Brother-Scribler's" pamphlet. Through the commonplace of rhetorical questions sprinkled liberally throughout, Swift planned his own piece to be read on one level as a parody of those orators, like Steele, who depended on histrionic sound rather than sense. On another level -this time through a pseudo-chronology of Steele's career, an "Account of this Gentleman's Importance"-Swift used his pamplylet to decimate the Whig journalist and relegate what remained to the status of a "prostituted" hack, a spiritual whore, who sold his talent to faction and his soul for secular gain. Distributed on 2 November, The Importance of the Guardian Considered suffered from a wobbling angle of vision; sometimes it was the mask of the explicator who saw and obliquely reflected; at other times it was Swift in propria persona who wrote in a blunt and straightforward prose. Whatever the weakness of the pamphlet, however, it became the model for writers who were ready to begin where it left off, more "to weaken"-so Stecle complained-"the Validity of what I said by Invectives against me, which came out stitch'd, bound, and in loose Papers for some Months every Week, than gain-say what I asserted." ${ }^{\text {.4 }}$

The Character of Richard St-le, Esq; by the buttocks-minded Toby [i.e., William Wagstaffe] converted Swift's disdain into derision, his wit into scabrous humor inseparable from indignation. If Swift minimized the Steur Tugghe's memorial as "trivial" and insinuated that its circulation was a Whig effort, Toby maintained it was "feigned ... if not written by Mr. St-le." Toby's words were chosen to destroy with "as much Violence as if [Steele] had been personally his most inveterate Eneny." "4t The pamphlet itself is a watereddown prose version of Juvenalian satire. Lacking declamatory grandeur and lofty sentiment, its rapid-firc attack was nevertheless charged with violent passion that commanded through anger and mockery an almost elemental revulsion against the Whig journalist. Its materials were structured for the titillation of an audience rather than for logical persuasion. Toby's debate-if such it may be called-was one-dimensional epideictic, with blame rampant. Yet what argument there was became vivificd by a serics of pictures, not always related or sequential but made to scrve the thesis that Steele was untrustworthy, incompetent, fraudulent, ungrateful, and unwholesome.

Toby likened his opponent's political involvement-whether as a writer or 
member of parliament--to infantile dabbling in excrement. As the pamphleteer beheld his witless subject, he apostrophized the one-time admirers of the Taller, the Speciator, and the Guardian. He forced them to face the humiliating trutl that their hero was the smallest of the maggot-sized hacks, trailing his slime behind him. "See the Man who talked like an Oracle, who had all the Gay, the Delicate, the Humorous, at his Command, calling Names, and daubing his Style witl the Language of a Scavinger!" Toby, further, manufactured a torrcntial wrath when he thought of the parading hack made rich and respectable. Yet for all the trappings of success, he was depraved, a "Judas" prepared to sell out Queen and friend if the bribe were sufficiently large to reach his vestigial conscience. In Toby's pamplilet appeared a portrait of Steele as the physical embodiment of Swift's lip-service Christian, the hypocrite who mouthed value words which he did not understand and which he never translated into performance ${ }^{4}$ No wonder Steele saw the two men as one. Clearly they shared a single spirit when in their assault they accused him of a perversity so selt-clclusive that it contradicted reality itself.

After many pages of fury alternating with horse laughter, the pamphlet ended-again in imitation of its Roman original-on a note of benign advice. But in this case the benignity was pretense and so it emerged as yet another snicker. "If I might Advise him, I should think it his best Way to retire into Wales, and Live upon his Estate; for by these Means he may keep his Circumstances within Bounds; and when his Head is Cool and Purged of his Politicks, he may now and then revisit and divert the Town, by publishing the Works of his Friends, and retreive the little Reputation he had gained by them." 'The most popular of the anti-Stecle pamphlets in 1713, The Character-according to a later admirer-entered "this Paper-War with no other View but supporting the Ballance of Pamphletecring." Far from ameliorating the hostilities, it gave them new intensity. Indeed, Toby's offering went through four editions to prove that crue]ty is always a marketable commodity. While it denied Steele even the solace of "Pity," it nonetheless failed in its ultimate intention. The diatribe never reduced "Old Ironsides to so low a Condition, that perhaps he may be glad to put an End to this long and bloody War."'7

A few more Tory pamphlets limped after Toby's in that same year, the most orrinous of which was John Tutchin's Ghost to Richard Stecle, Esq; printed in Decernber. 'Through a single analogy, the prose-verse polemicist pulled tight the umbilical cord between the two Whig writers. By virtue of the fiction spelled out in the crude Mil tonic lines, Steele was brought on stage as a journalistic offspring of Tutchin and equally demented. The abortive plot 
dramatized Stecle's metamorphosis-the work of his putative parent-into the Englishman. "On the 5th of October last," a disembodied Tutchin

Seeing that the Hero lay

A senseless Lump of Flesh, inanimate,

His Oaken Towel to His brauny Back,

He thrice apply'd,

And with a Voice, much louder than before;

'Rise up, rise up, tise up, O Englishman,'

He cry'd.

No sooner did the specter speak than what he said was done. The "Hero," revived,
A wondrous Change within himself he found;
He set him down, and, at one glorious Heat,
With Inspiration swoln, and staring wild,
Struck out the First, the Conquering Englis/zman.

Never stated in this tawdry piece was the real possibility that Steele might go the way of the Obscruator's editor, beaten to death by a gang of unidentified hoodlums whose fists, like everything else, were for hire. ${ }^{49}$

\section{IV}

Sometime in 1713, in the midst of all this journalistic baying, there appeared a quiet bit of critical writing by Henry Felton, tector of Whitwell in Derbyshire. He recommended to John Roos, Marquis of Granby, the literary genius of Squire Bickerstaff, grave and comic, "who hath drawn Mankind in every Dress, and every Disguise of Nature, in a Style ever varying with. Humours, Fancies, and Follies he describes. He hath showed himself a Master in every Turn of his Pen, whether his Subject be light, or serious, and hath laid down the Rules of common Life with so much Judgmert, in such agrecable, such lively and elegant Language, that from him Your Lordship at once may form Your Manners and Your Style." Almost indifferent to such praise because it recalled a life he had temporarily forsaken, the erstwhile Bickerstaff heard the words of a "Mr. Condon," whose language was strangely like English 'Tory's in Guardian No. 128. ${ }^{40}$ Since Steele created multiple identitics for his political self $\rightarrow$ a device the Opposition delighted in uncovering-it is possible that the two letter-writers were one. On the first day of 1714 they thought alike, motivated by their detestation of an unnamed minister, their love for a deceived queen, and their reliance on a mijority whose felt presence spurred them to decisiveness. 
Thongh I am generally very well entertained with all your Writings upon whatever Topicks you think fit to employ your Pen, yet, I must own, I conld wish that at this Critical Conjuncture, you would think your self obliged, as the Author of a Paper call'd, The ENGLISHMAN, more particularly to make choice of Subjects of a publick Nature, and endeavour rather to instruct than divert. . . Fear not the silly Cunning of pazaled Politicians; Court the Favour of the good People by attacking boldly those Fellow-Subjects that would entirely engross the Favour of the Good Queen, and dare to show for the Service of your Country, the wide Difference Between the Raw, the Voluptuous, the doubledealing Minister, and the Experienced, the Diligent, and the direct Statesman, how great a Blessing the one is to a Nation, and how certainly the Curses both of his own Time and future Generations will attend the other. ${ }^{\text {si }}$

In fulfiling this duty, Steele faced a few hard truths, that he would be expelled from the House and that he would be mauled by Tory journalists, who had only flexed their muscles in 1713 . He had taken the measure of his world well enough to anticipate his destiny. Because The Crisis had been advertised so widely and he had already "got into the Fire"-as Swift taunted him on 6 or 7 fanuary-lie could not "easily retire." In truth, he could not retire at all, and so on 19 January he masked himself in that pamphlet as a professional liberator, alerting his audience to possible authoritarian dangers that lurked everywhere. His work fell far short of its promise if only because it had long been heralded by the Whigs and long been dreaded by the Tories. Perhaps the "Train of Dukes, Earls, Viscounts, Barons, Knights, Esquires, Gentlemen, and others, going to Sam. Buckley's the Publisher of the Crisis, to fetch horne their Cargoes" was not quite "huge," but some 40,000 pcople spent a shilling each for Steele's latest effort. ${ }^{51}$

The pamphlet was constructed upon a volatile arrangement not of ideas but of emotional attitudes and moods. Its persona was less Steele than his pliable spokesman, who could appear frightened or aggressive, worldly or pious, and even disappear altogether. For a short while, the first-person narrator thus surrendered his place to objective legal statement. Finally he eradicated the self completely to assume the comprehensive we, the symbol of consensus. The author of The Crisis proper deliberately played to his readers just as he had when he wrote single sheets. In both instances he trusted their capacity to react to the tonal acrobatics of Steelean oratory. This implicit trust, as much real as feigned, gave the pamphlet its sense of assurance and righteousness. It was-and it told the world so-written by a good man for good people. 
The body of the debate began with a humble definition of liberty which in its lack of pretentiousness planned its appeal to all men living in a parliamentary government. Lest the definition be spurned as subjective, it was documented by a somber array of laws and precedents serving notice "that all the Notions of Hereditary Right ... are at an End." As a consequence the spokesman experienced a sudden upsurging of optimism about the safety of England's constitution. But almost as soon as such confidence was expressed, it was punctured by a series of rhetorical questions.

I ask my self ... what are the Marks of a lasting Security? What are our Tempers and our Hearts at Home?-In what Hands is Power lodged Abroad? Are our unnatural Divisions our Strength? $-O$ Or is it nothing to us which of the Princes of Europe hath the longest Sword? 'The Powerful Hand that deals out Crowns and Kingdoms all around us, may it not in time reach out a King to us too? Are there no Pretensions to our Crown that can ever be revived?-Or are Popery and Ambition become tame and quiet neighbours?

The staccato-like presentation of the questions almost precluded response. 'They were, however, dealt with by a swift succession of pictures, which prodded reader imagination "to run over the good events that happened" during the dynamic war years and to quail before the varied scenes of Catholic tyranny, both English and foreign, past and present. During this kaleidoscopic show the $I$ proliferated into we "to maintain and assert the Protestant Succession in the illustrious House of Hanover." The theme was pronounced without equivocation, and the pampluet ended on a quasi-apocalyptic note, with an awareness of Jehovah, who, as a God of wrath and justice, would preserve England's mixed government and damn its subverters. Of this the $l$, the we, and unnamed multitudes-the changing personae-of The Crisis were sure.

The paper war was immediately excited to new spurts of attack and counterattack, all in all a shrill adventure planned for over the last three months. The Examiner, ever-present, began its new complaints on $22-25$ January. The volume of the Tory dis increased as pamphleteers wrote purportedly in defense of the clergy: for example, Remarks on Mr. Sieele's Crisis, Ec. By One of the Clergy, printed on 26 January, and Remarks upon Mr. Steele's Crisis, Humbly inscrib'd to the Clergy of the Church, sold on 2 February. Within another two days Mrs. Manley introduced A Modest Enquiry into the Reasons of loy Expressed by a Certain Sett of People, upon the Spreading of a Report of Her Majesty's Death. ${ }^{\text {Ba }}$ But before Swift could contribute his bit to the general huffing and puffing of political indigation, Steele rose once more to affirm his 
commitment, this time in Englishman No. 57 distributed on 15 February. The essay, swollen to pamphlet size and circulated in that form, saicl little that had not been said before. It retracted nothing. To outflank his observers and to be known in his entirety-the M. P., journalist, politician, and man of good will -Steele spoke in the voice of an injured patriot, who insisted "that what I have done Alowed from no other Cause, but Zeal for the Honour of the Queen, the Safcty of the Constitution, and the Happiness of the People."

With the close of the Englismon, the Whig propagandist saw no logical need to pursue the war. He had accepted all contests and, while often hit, he had lost none. He therefore did not react to the scatological farce of $A$ Letter from the Facetious Doctor Andrew Tripe, published on 16 February when Parliament opened and he took lis seat as the member from Stockbriclge, the borough-as one pamphleteer put it-that "would Return Lewis Baboon himself, if his Lowis D'or's, outweighed [Steele's] Guineas." One weck later, on the 23rd, he threw off the mockery of The Publick Spirit of the Whigs in which Swift hoped to settle old scores and deftate his opponent as an insinuating "Politician," a "child of Obscurity," a pedant and maxim-monger "grossly defective in Truth, in Sense, or in Grammar," a "CREATURE" stripped of humanity." But Steele had learned he could not be vilified or jeered into insignificance. He knew that the Tory-dominated Commons in voting his expulsion would paradoxically prove his political worth.

In less than a montl-on 11 and 12 March-it was formally charged that several paragraphs of The Crists, the whole of Englishman No. 46 and the final number of that paper "were sandalous and seditious Libels" designed to erode confidence in the Queen, "to alienate the Afections of her Majesty's good Subjects, and to create lealousies and Diwisions among them." The journalist's one-day trial on 18 Marcl was like a dampened firecracker after his five-year war. The Tories had been so confident of their ability to have the accusation moved and seconded that they had permitted the Examiner and pamphleteers to anticipate it as a coming event. As early as August their writers denounced Steele as "unclean" and cried for his expulsion. Even morc predictable than the trial was its verdict. The ubiquitous Examiner-wrotc one Whig-did not wait for the vote which was counced at midnight after a long harangue from both sides. It scooped the judgment in an issue printed at noon of the same day-that is, "near 12 Hours before it was done."

Steele was to live through several paper wars but the one that began in May 1709 and ended for all practical purposes on 15 February 1714 provides its 
own drama and biographical importance. Probably because it was the first of his wars, he was neither bored nor squeamish about his activity. He did not visibly slacken his effort, and what he wrote suggests a tense acuity however it was turned and disguised by the several masks he wore. His political literature, produced under pressures of time and exigency-under lures and threats -offers new dimension to his genius and personality. At one and the same time he revealed both nervous energy and real staying power. Seemingly dependent upon others for moral support, he had himself learned to grow a thick carapace of emotional self-sufficiency. For all his financial grubbiness he was committed to what he believed was ideological purpose; for all his delight in civilized pleasures, he realized that to attain a freedom of spirit he had to be above material cares.

Within the context of his political writing he made mysteriously credible the self-portrait of the victin courageous in faction's cause. "In Defence of Truth," he stated, "I incurred popular Hatred and Contempt, with the Prospect of suffering the want even of the ordinary Conveniences of Life." He saw himself in that part, accepted what he saw, and did not overstate its perils. Fact, nevertheless, abetted a journalistic cunning. He either knew or intuited that this was the most compelling of oratorical postures, one recommended by Quintilian and Cicero on the assumption that "men have a natural prejudice in favour of those who are struggling against difficulties." Strategically placed in many of his party-oriented pieces were these quick verbal pictures of a David throwing stones at a Tory Goliath, a Whig persona's uneven fight against "powerful talents arrayed against him." ${ }^{\mathrm{ts}}$

Matched against the strong figures of Defoe and Swift--even Wagstaffe, Oldisworch, and Mrs. Manley-and surrounded by Grubeans, "these Sons of Calumny and Defamation," he had to fight hard because he fought for survival. If ever he wished to live in a world free of political enemies, he suppressed the desire and continued to broadcast the Whig message until his party's return to power was inevitable. He came forth from this first paper war as a proved rhetorician, particularly adept at insinuation-the most malicious of oratorical devices. Yet he ordered his debate so that it skirted "Ribaldry, and Billingsgate." Victimized by ad hominem criticisn, he avoided-when he conld-the personal attack. He wrote often with a sense of factional urgency and perhaps of spite inextricable from hurt. But, regardless of the judgment of the Commons, he rarcly gave way to divisive anger that "vents [its] Splcen in Libels and Lampoons." He used his political essays and pamphlets as a one-man show, adjusting his performance to altering circumstances-to support a ministry, if Whig, or to extirpate one, if Tory. Steele was a political animal for 
most of his life. But never did he wear his beast's skin with greater flair and more danger than in his first paper war.

\section{Notes}

1. Sec Guardian No. 63, which also contains Steele's ironical apology, "begging [Mrs. Manley's] Pardon, that I never lay with Ter."

2. Secret Memoirs and Monners of several Persons of Quality, of Both Sexes. From the Nero Alalawtis (printed for John Mnrphew near Stationer's-I-Iall and J. Wood ward in St. Christopher's Street). Mrs. Manley's portrait of Steele appenrs in the first volume of The Neto Atalantir, pp. 187-93. Her statement of technique is in a letter to Harley, 12 May 1710, in Hist. MSS. Com., The Manuscripts of his Grace the Duke of Portland, IV (London, 1897), 541 .

3. For a statement of the Guzettecr's function and perquisites, see Swift's lourmal to Stella, ed. Harold Williams (Oxford: Basil Blackwell, 1974), II. 543: and Robert Waller Achurch, "Richard Stecle, Gazettecr and Bickcrstaf," Studier in the Eanly English Periodical, ed. Richmond P. Bond (Chapel Hilt: University of North Carolina Press, 1957), p. 56. Addison in Specturor No. 452 describes bow news is "cooked" to pany order.

4. 19 April 1709, in Hist. MSS, Com., Portand, IV, 522-23. The fitst Tatler appeared on 12 April (all quotations from the Tatler conform to the edition by George A. Aitken, London: Duck worth, 1898).

5. Swift so described Mrs. Manley"s polirical values in the lournal to Stella, II, 474.

6. The Correspondenee of Richard Stele, ed. Rae Blanchard (London: Oxford University Press, H. Milford, 1941), pp. 28-29. The original letter is now in the Donald and Mary Hyde Collection, Four Oaks Farm, Sonerwille, N.J.

7. Stcele's appreciation of good clothes ind company necurs in a letter (19 May 1708) to his wife, in Correspondence. p. 219. Swift's rospect for Mrs. Manlcy's Toryism and political writing did not extend ta her persors (Journal to Stella, Il, 474). For an objective account of Mrs. ManIcy"s relationship with Steele. set: Pan! B. Anderson, "Mistress Delarivière Manley's Biography," MP, 33 (1936), 261-78; and Correspondence, pp. 435$26 n$, 429-30n.

B. See her leller to Harley for 12 May 1710, cited above.

9. Letter-Books of lohn Hervey, First Earl of Bristol ed. Sydenham H. A. Hervey (Wells, 1894), I, 249. Thomas Hopkins was appointed Under-Secretary to Lord Sunderland on the same day that Addisurt was similarly appointed (3 December 1706).

10. King William is identified as the "Iate glorious King" of Felicia in Tatler No. 4; the victories of Blenheim and Ramillies are described it Tatler Nn, 2; the culogy of Martborough is preseneed in Tatler No. 5.

11. The Present State of Wit, datcd within the text 3 Miy 1711.

12. Taller No. 111; L. S. Ladam, The History of Fngland (1702.1760) (Landon: Longrnans, Green, and $\left.\mathrm{Co}_{0}, 1909\right)$, np. 141-42; and Geoffrey Holmes, British Politics in the Age of Anne (London and New York: Metrillan and St. Martin's Press. 1967), p. 69.

13. Tatler Nos, 44, 45, 50, 51 .

14. Taler No. 142; of. Tatler Nos, 140, 141. The Whigs were surprised by the popularity of the Sacheverell cause and, consequently, had little choice but to rely on a tactic of silence. Addison in Whige Examiner No, 4 distnissed the clergyman as having "hit the sublime in nolssense." His statement is a recapitulation of one made by Stanbope during the impeachment (Abel Boyer, The History of the Life and Reign of Queen Anme (London, 1722†, p. 415).

15. For accounts of the peace conference at the Hague, sce Tatler Nos. 13, 16, and especially 23; for accoutnts of French suffering, Tatler Nos. 18, 19, 27. Jean Baptiste de Torcy was the French ambassador to the peace conference at the Hague.

16. Tatler Nos, $210,187$. 
17. See her Dedication to Henry Duke of Beaufort in the second volume of The New Atalantis.

18. Printed and sold by Benjarnin Bragge, at the Black-Raven in Pater-Noster-Row, nd.

19. The suggestion for the threat mily have been derived from the Femalc Tatler ( 8 July 1709-31 March 1710), 98. First printed by Benjamin Bragge, the journal was fought over by Mrs. Ant Baldwin, who for two montlys produced a rival paper with the same title. The tady apparently won possession of the periodical.

20. For the nature of the Examiner's attacks frrior to its fith isstre, see the number dated 10.17 August and also A Letter to the Exaniner (London, 1710), p. 4. Addison's counterattack appears in Tatler No. 229. The Whig analysis of the Taller's offense is recorded by Iohn Oldmixon, The Lite and Posthumtows Works of Arthar Maynwaring (London, 1715), p. 159.

21. Fretholder No. 19.

22. The Whig obscrver is Oldmixon, p. 11. See Swift, Remarks apon a Book, intitled, The Rights of the Christion Church, \&c, in Bickerstaff Papers and Pamphlets on the Church, ed. Herbert Davis (Oxford: Basil Blackwell, 1957), pp. 67-107.

23. No printer or date is given for The Loyal Calves-Head-Club. A Condoling Letter was printed and sold by $S$. Popping, at the Black-Raven in Pater-Noster-Row. It was inspired by Stecle's incarceration for debt in April and again in August. For nnother attack on the periodical, see W. Oldisworth, Annotutions on the Tatler, written originally in French, by Mons. Bournelle, and tramslated into English by Walter Wagstaf, Esq., 2 pt. (printed in September for Bernard Lintott).

24. Tatler No. 195; see also Taller Nos. 214, 229, 232, 237.

25. Moderator No. 42. The journal, solk by John Marphew, nan for fifty numbers between 22 May and 10 November 1710. The Friendly Couriere, of which oniy No, 1 appezred, was printed and sold by $A$. Baldwin, in Warwick Lane for $3 d$.

26. Oldmixon, p. 193.

27. A Letter to Isaac Bickerstaff. Esqu; Occasion'd by the letter to the Examiner. The panplulet, far which no printer is given, sold for $2 d$. See also $A$ Character of Don Sacheverelio (Dublin: printed and sold by Francis Higgins, hookmaker; and to be had of A. Boldwin in London, c. 1710). The price was $2 d$.

28. The "Prefince" to A Spy upon she Spectaror (London: printed for Morphew, 1711); and Spectator No. 61. The Spectntor was largely associated with Stecle. Swift in the Journal to Stellat $(\mathrm{I}, 218)$ on 16 March 1711 described the periodical: "Tis written by Mr. Steele, who seems to have gathered new life, and have a new tund of wit."

29. See Spectator (ed. Donald F. Bond (Oxford: Clarendon Press. 19657) No. 384 and $\pi .2$; Plain Dealer No. 7 is reprinted in Wagstuffe's Miscellaneots Works (London. 1726), pp. 240.58. See also the Examiner for 22-29 May and 17-24 July 1712 and Switt's Letter of Thanks from my Lord W[harta]n to the Lord Bp of S. Asaph [Tuly 1712], in Political Tracts 1771-17/3, ed. Herbert Davis (Princeton: Princeton Liniversity Press, 1951), pp. 15155. The pamphlets on both sides of the controversy are discussed by John C. Stephens.s. Jr.. "Steele and the Bishop of St. Asaph's Preface," PML.4, 67 (1952), 101123; and Goldgar, pp. 102-106. No. 43 .

30. The British Censor, printed for J. Paker. For Steele on "Dulness" see Spectator

31. Correspondence, p. 298. This proved to be but a taste of rewards promised him some six months later. See his letcer to Mrs. Stecle for 4 August 1714, in Correspondence. p. 304.

32. Stcele's Letter to Sir M. W. was ill-timed, its argument forgotten in the joy of the pence. It provoked only one extant response: Reffections on a Paper lately printed, ontitied, A Letter to Sir Miles Wharron, conceming Occorional Peers (London, 1713). Steclers goal was described in The Character of Richord St-le, Esq; With some Remaths. By Toby Abel"s Kinsman. Priced at fid., the parnphlet was printed by Morphew and 
probably distributed by 12 November 1713. Sce also [John Arbuthot?], An Invitation to Peace, printed and sold by Mr. Lawrence, near St. Paul's Church-Yard [1714].

33. Hist. MSS. Com., The Appendix to the Seventh Report (London, 1879), VII, 239; Bayer, History, p. 641; and his Politionl State of Great Britain, VI, 21. Fur a statement of the tictic, see Swilt's History of the Fon Lat Years of the Queen [1758], ed. Herbert Davis with an introduclion by I-Iarold Williams (Princeton: Princeton University Press, 1951), pp. 5-7. For the year in which the strategy was devised, sec Charles Lawton to Farley, 30 Sept. 1711, in Hist. MSS, Porland, V, 94.

34. Stecle held back tonger than some. He was preceded, c.g., by Addison in The Late Tryal and Convicion of Count Tariff, published for A. Bnldwin on the hast day of June 1713, and by George Ridpath, Some Thoughts concerning the Peuce, printed for Rober: Aldsworth in 1713 .

35. Examiner for 1421, 21-24 August. Defoe's pamphlet was printed for Morphew, probubly distributed by 14 August (advertised in the Examincr 10-14 August under the rubric "This Day is Ptuhlished") and sold for $3 d$. Sce also Rersons concerning the $\mathrm{Im}_{\text {- }}$ mediale Demolishing of Dankihk, printed for Morpluew and sold ty mid-September.

36. "This pamphlet, with its epigraph "Chalybem froenosa; momordit," was printed for Morphew and put up for sale by the last week in Septemler. Its uuthor had apparently not scen The Importance of Dankink Considu'd.

37. Gurrdian No. 160 .

39. The Impotance of the Guardin Constided (printed on 2 November for Morphew and sold for 6d.) in Polisical Tracts 7713.1719, ed Herhert Davis and Irvin Ehrenpreis (Princeton: Princeton University Press, 1953), p. 20.

39. Guardian No. 168: The Importance of Dunkink Considerd (printed for A. Baldwin in Warwick Lanc), in Thets and Pamphlets of Richord Stecle, ed. Rae Blanchard (Baltimure: The Johns Hopteins Press, 1944), pp. 87-124. Stecle took a rhetorical delight in kepping score-those articles written on his hehalf and those against. For his tally conceming Guardian No, 128, see No, 168 of the sane joumal. See also below, n. 50 .

40. The Fronch Foith Represented in the Present State of Dankirk (printed and sold by F. Burleigh in Amer Corner, July 1714), in Tracs and Pamphles:, F. 260. The aceusation of sedition had alrealy heen made against Sicele; sce. e.g.. Eraminer for 21-24 Aug. and Reasons concening the thmedithe Dewolisting of Dunktrk. Between 25 September and 23 Otnber, the Examiner spent frul issues attacking Stcele. The Infortance of Dushirh Consider'd, and the Fnglishman.

41. Printed for Morphew and priced 3d, the Dialogue was distributed hy 17 October.

42. The Leters of Jaseph Addison, ed. Walter Graham (Oxford: Clarendon Press, 1941) + P. 280. Stecle's method of attacking the ministry was described by $S$ wift in $T h e$ Imporance of the Guardian Conridrred. $\mathrm{Pp}, 9,20$.

43. The same sportive dismissol of Stele ns a political thinker is also evident in Swift: First Ode of the Second Bool of Horace Pulaphra'd (printed for A. Dodd at the Peacock withour the 'Temple Bar, anld for $3 d$, and dated 1714 (in a few ropies 17131), in The Poems of lonathan Stwift, ed. Farold Williams (Oxford: Clarendon Press, 1937). T, 179-84.

44. Mr. Stede's Apology for Himielt and his Writings (printed and sold by R. Burleigh in October 1714), in Track and Pamphlet, p. 285.

45. Fnglishman No. 57. For the colloquial menning of toby in the carly eighteenth century, sec Eric Partridge. A Dictionily of Slang and Unconnentional English (Iondon: Rontledge and Kegan Panl, 1961), vol. J.

46. See The Argument agamst Abolishing Chrrianily in England [written in 1708; published in 17111, in Bickerstaf Papers and Pamphlcts on the Chwch, pp. 26-39.

47. Sec An Intritation to Peace, in $n .32$, above.

48. John Turchin's Ghost, printed for Morphew, was sold on 8 Iherember for 3d. It was predated 1714 on the title page. See also Another Letter from a Country-Whig to Richard Stcele, Esq; (printed for Morphew, sold by 17 Novenuber). 
49. A Dissertation on Reading the Classics, and Forming a Jast Style. Written in the Year 1709, and addressed to the right Honowrable, Joln Lord Roos, the present Marqui, of Gronby, Pp. 252-53. The rare first edition was printed in 1713; the sccond (printed for Jonah Bowyer, at the Rose is Ludgate Stret) in 1715. Beginaing in Fobruary 1714, the Lover ran for forty numbers.

50. To the Author of the Englishnan. Writen to him on New-Years Day [1714]. and Published now for the Benche of will his Fellow-Memben, whether Whigs, Tories, or New Conwerts (unpaged broidside). The Whig pamphleters did not expend muth effort in defending Steele in 1713. In Grardian No. 168 he fisted two who wrote in defenst of his Gurdian No. 128. The more llattering of the two was the author of A Lefer from an English Tory to his Friend in Town (printed for E. Snith, 1713). After The $/ m$ portance of Dankik Consider'd was published, he had a strang supporter in Abel Boyer in The Political. State (November) and in the anonymous pamphleteer who wrote Two Lellers Concerning the Atahor of the Examiner, which exposed and denounced Swift as the Tory journal's atuthor. Stesle was supported indisectly by those who wrote bn behalf of Whigr principles and in opposition to the Examiner. Sce, e.g, the two pamplulets by Samuel Croxall: An Original Canto of Spencel (printed for James Robets, predated 1714 but sold for 6d. by the end of November 1713); and The Examiner Examin'd (printed tor Roberts and distributed 23 December).

51. Swift's taunt appears in The First Ode of the Second Book of Horace Paraphras'd. The description of the reacling public of The Crisis is Swift's in The Publick Spirit of the Whigs (printed for Morphew and sold for 1s.), in Political Tracts 1713-1719, p, 33. The Crisis, printed by Samuel Buckley and sold by $\mathbf{F}$. Burlejgh, appears in Tracts and Pamphlets, pp. 129-81.

52. The Tory Remarks, an ambitious effort, was sold by B. Berrington, near Essex Street in the Strand, and E, Smith, ar the Royal Exchange in Corahill. The price was 6d. The Whig Remarks was printed for Bernard Lintot, at the Croskcys between the two Temple Gates in Flect. Mrs. Manley's Modent Fngniry was printed by Morphew. Cf. $A$ Letter to Mr. Steclc, concerning the Removal of the Pretender from Lotratin. occationed by the Crisis (this attack in doggerel is signed Tim. Tomkins and is undated); and Crisis upon Crists (printed in April for Morphew).

53. Printed for Morphew, A Letfer was actually written in and finished by November 1713. The remark about Stokbridge appenrs in Another Letter from a Connty-Whig. During February at least two other anti-Steele pamphlets appeared: by 6 February The Life of Cato the Censor (signed "Daniel Doggrel"); and Jack the Conterer's Ancuer to Dick the Englishmun's Close of the Paper so called (printed for E. Smith, 1714).

54. The Whig account of the trial comes from The Case of Richad Secle, Esq;. Printed by Rolserts, it sold probably in late March or carly April for 6d:; the same pamphlet also appearcel under another title: A Full Account of the Procedings in the last Session of Parliament, agaitust Richard Stecle, Esq. (printed for Roberts, 1714). The Tory version is best symthesized by The Miscrmige of the Whig.Ministry . . to which is added A true and exact list of those Members, who, to their great dishonour, voted against the exptlsion of Mr. Sicle (printed and sold for $3 d$. by the hooksellers of Westminster and London). For those papers demanding Steele's expulsion, sce, e.g., Examiner for 14-21 August 1713; Another Leter from a Country-Whig; and An Invitation fo Peace.

55. The Dedication to Mr. Sreale's Apology for Himself and hir Wrings (printed and sold by R. Burleigh), in Tracts and Pamphlets, p. 279. Quintilian, In.cistito Oratoria, tr. H. E. Butcer (Londop and Cambridge: William Heinemann and Harvard University Press, 1963), IV.i.89; Cicero, De Oralore, tr. E. W. Sutton and completed by H. Rackham (London and Cambridge: Willinm Heinemam and Harvard University Press, 1942), It, 184, 211.

56. Spectator No. 451. 


\section{"A Truly Elegant Work": \\ The Contemporary Reputation of \\ Hawkesworth's Adventurer}

\section{By Philip Mahone Griffith}

After almost a half-ccntury of imitations in the Tatler, Spectator, and Guardian tradition, a "second efflorescence" of the single essay periodical appeared during the seventeen-fifties." The most notable of these periodicals and the one "usually ranked as the first of the classical periodicals after the Guardian" was Samuel Johnson's Rambler (1750-52)." "The influence of the Rambler in purpose, in style, and notably in physical format was as certain as that of the Tatler. In November of 1752, for example, appeared the following advertisement: "The Rambler being finished, another periodical paper has appeared, called the Adventurer. It is printed after the manner of the Rambler, and sold also at Two-pence each number, published Tuesdays and Saturdays." The Adventurer, edited by Johnson's then intimate companion, John Hawkesworth, is, uncquivocably, the foster child of the Rambler. Indeed, Sir John Hawkins, who was in a position to know, stated: "The avowed end of the Adventurer, being the same with that of the Rambler, and the plan and conduct thereof so little different from it, the latter may be considered as a continuation of the former."

As proof of the immediate contemporaneity of at least some of the early issues, No. 3 (November 14) is a burlesque on the squabble between Garrick at the Drury Lane Theatre and Rich at Covent Garden which culminated in a concerted riot at the Drury Lane. On November 8 , in a revival of his pantomime, The Fair, Rich had alsured the Town to Covent Garden with a wire-dancer (Maddox from Sadler's Wells), some ostriches, and other animals from Bartholomew Fair. From November 9 to November 14 Garrick ridiculed the entertainment by presenting a divertissement of the same kind at Drury Lane; mock scenes were introduced into Henry Woodward's pantomime, Harlequin Ranger, in which Woodward played Harlequin. On the evening of November 9 a party favorable to Rich went to Drury Lane and one of their number, Richard Fitzpatrick, threw an apple at Woodward and hit him. A pitched battle followed between the Garrick and the Rich forces, and this in turn resulted in a renewal of the "Paper War." Dr. (or "Sir") John Hill, the "Inspector" of the London Daily Advertiser, defending the Covent Garden faction, attacked the combined forces of Henry Fielding in his Coventarden 
Journal, Bonnell Thornton in the Spring-Garden Journal, and Dr. John Kenתcdy in the Whipping Rods, each of whom, at this time, sided will Garrick. On the very day that Garrick withdrew his offensive burlesque, November 14, the Adventurer entered the fray. The third issue, signed by "LUN Tertius," describes a project for a pantomine called "E-Tarlequin Hercules" in which Harlequin should perform the twelve labors with all the fabulous theatrical resources available. The burlesque is a hilarious reductio al abstrdum of both the fad for more sensational pantomime and the recent squabble. ${ }^{5}$ The fact that a contributor to the Adventurer was willing to seize upon an event of such immediate Grub-Street notoriety and ridicule it so successfully indicates clearly that the "fraternity" had an eye to current popular inerest and was willing to gratify it in the airiest manner possible.

The Adventurer did not escape the whip of the Inspector's wrath; Hill attacked both Kennedy and the Alventurer on Friday, November 24 (in No. 533 of the "Inspector" series). His pretense at having read only the first issue of the Adventurer is obvious from his reference to Hercules:

That a shect and Half can be written without a single Thought, I mean a Thought that is either new or to the Purpose. I quote the whole Adventurer; be it always remembered, that in mentioning the Writer, I mean in his first paper, since I imagine nobody else has any more than myself look'd at a second. But cruel as this Censure upon the something and nothing, the somebody and nobody of that elaborate Writer may seem, let not any of his Brethren be discouraged by the Sentencc. Words may be pur together without Thoughts; and they shall sound as loud, as those which leave the Load of that unnatural appendage... I I am sorry to produce a Rival for the Author whom I have celebrated with so much Justice in the Beginning of this Paper; but surely as the Vatour of this Champion out-Hercules's Hercules, his Modesty out-Kennedies even Kennedy.

This kind of essay, in spite of Hill's denigration or perhaps because of it, with its currency and comic vitality, did much to make the Adventurer a success with the reading public. Hawkesworth and his friends were fortunate to have enlisted the services of the anonymous humorous writer "A," and the Genteman's Magaxine, edited by Edward Cove, a close friend and benefactor of both Johnson and Hawkesworth, quickly picked up humorous issues of the Adventurer for monthly publication. In the November issue Cave gave a summary account of the first four issues of the paper and reprinted the whole of No. 5 (November 21). In December he included among "Books publish'd" 
the sixteenth issue of the Adventurer and remarked: "...we designed to have given one of this month's Adventurers, finding that No. $\mathrm{V}$ inserted in our last was entertaining to all kinds of readers; but our book filled before we were aware, and therefore shall refer them, and several other pieces now omitted, to our supplement, which will be publish'd about January 20." It is difficult to believe that an astute and eminently successful editor like Cave, even though he was not a totally disinterested party (both Hawkesworth and Johnson were continuing contributors to the Gentleman's Magazine), would have reprinted so many isstes of the Adventurer if it had not from the first caught on with "all kinds of readers." This popularity in the early months of publication seems to have been well sustained.

Arthur Murphy, the editor of the Gray's-Inn lournal (October 21, 1752October 12, 1754), compared the Adventurer's reception in No. 53 (October 20,1753 ) with that of his own journal;

In the softer Climate of St. James's Air, I was told, that my Bays are likely to flourish, and I was particularly assured, by a Gentleman who frequents the Cocoa-tree in Pallmall, that Ranger ["Charles Ranger, Esq.," Murplyy's eidolon] has gained Admittance there notwithstanding their Attacliment to the ADVENTURER. ${ }^{8}$

The Adventurer, if Murphy's report is to be taken seriously, must have attracted a significant circle of readers in the more exclusive coffeehouse circle. Murphy's journal, though perhaps closer to the World and the Connoisseur in manner and matter, is near to the Adventurer in its serious papers of literary criticism; the two former papers iseat literature, like most other topics, as an aspect of manners.

Murphy seems to have been particularly aware of the rival claims of the Adventurer. Later an erninent dramatist himself, he devotes much attention to individual plays of Shakespeare. His critiques, like those of Joseph Warton, have real historical value in their emphasis on Shakespeare's preeminence through characterization rather than through plot. Murply ranked Lear as Shakespeare's masterpiece and participated in a controversy conerning Lear's madness. Warton had written in his final paper on Lear in the Adventurer:

Madness being occasioned by a close and continued attention of the mind to a single object, SHAKESPEARE judiciously represents the resignation of his crown to dauglters so cruel and unnatural, as the particular idea which has brought on the destruction of LEAR, and which perpetually recurs to his imagination and mixes itseif with all his ramblings. ${ }^{*}$ 
fore inclined to flatter myself, that my Expression has been natural and unambitious; and that my Arrangement has been grammatically just, unperplexed and clear, and that upon all Occasions I have written with some Degree of Purity.

Upon the whole, if I cannot boast of having produced edifying Strains of Morality, Dissertations of uncontrovertible Criticism, and Papers of exquisite Mirth and Humour, I hope, at least the whole Plan has been conducted with a strict Regard to Decency, and without any Offence against Virtue or good Manners. ${ }^{15}$

This is almost a resume of the three final summing-up papers in the Adventurer by Johnson, Warton, and Hawkesworth, and it is a telling commentary on the prose style of much of that journal. Murphy's allusions to the Adventurer, his self-consciousness about its popularity and its content, are the most significant that can be found in a prominent and contemporary periodical. These comments attest to the influence of the Adventurer on Murphy's own journal and its important rank among essay journals in the periodical press of the day.

The Advcnturer, like the World and the Connoissewr, also supplied copy for the magazines. Ralph Griffiths' Monthly Revies, for which Hawkesworth himself became a notable assistant, announced the Adventurer's appearance and inserted the fourth issue as a specimen of his execution. At the conclusion of the project, the Monthly Review also advertised the book edition of the Adventurer and reprinted the final issue. "The London Magazine chose more liberally, from thirteen issues, and in the year following its appearance this magazine published a letter attacking No. 88 of the Adventurer, Hawkesworth's paper on the fanatic Simon Browne, which was answered in the following issue. But the anonymous detractor began his letter with high praise: "I have lately been very agrecably entertained with a truly elegant work called the Adventurer." Cave's Gentleman's Magazine, for which both Hawkesworth and Johuson were important contributors, reprinted eighteen numbers of the Adventurer either in regular issues or in supplements, and as late as 1778 published an old letter written in 1755 refuting the ideas in one of Hawkesworth's Oriental tales, the story of Yamodin and Tamira in No. 91 ${ }_{1}^{18}$ A wide range of subjects was borrowed by these magazines; every major contributor was tepresented, with Hawkesworth's Oriental and sentimental fiction predominating. The critical judgment of the editors seems on the whole to hav been good. The Covent-Garden lotunal of Dublin, 1752-56, which ber principally as a piracy of Fielding's Covent-Garden Journal, also reprinted 1 terial from the Adventurer as well as from the World and other periodic 
This assertion, that Lear's madness had resulted from his loss of power, Murphy atteropted to refute by a close examination of the play, scene by scene, in Warton's own manner. He replied: "As this [filial ingratitude] is the Groundwork of the Play, I am surprised that any Critic slould impute the Madness of Lear to the Loss of Royalty. The Behaviour of his Children is always uppermost in his Thoughts, and we perceive it working upon his Passions, till at length his Mind settled into a fixed Attention to that single Object." the following week Murphy published a perceptive letter from an anonymous correspondent protesting both his criticism and that of Warton and suggesting a comparison:

The Critic in the Adventurer was somewhat wanting in Justice to the Poet, by mentioning the Loss of Royalty as the sole Cause of Lear's Madness, without taking Notice at the same Time of the forcible Idea he must have of the Ingratitude of his Two Daughters; and I think Mr. Ranger also wrong, in excluding intirely his Opinion. What I purpose here is, to point out both the ldeas working strongly in his Mind, and what the Author intended as conducive to the Moral of his Play."

Besides quickly picking up Warton's criticism of Lear in the Gray's-Inn lournal, Murphy had earlier praised Warton for his critical knowledge as the editor of Virgil. ${ }^{12}$ And in a dream visit he makes to the Houyhnlinms Murphy encounters the Master Houyhnhnm and answers further questions about the state of Europe, Great Britain, and the Yahoos. He identifres Gulliver for the Master as "Dr. Swift" and presents him "with that elegant Edition of Swift's Works lately published by Mr. Hawksworth [sic]." "Finding the worthy Houyhnhnm to be very much pleased with this Performance of Mr. Hawkes worth," he writes, "I made him a Present of the Adventurer in four Volumes, which he received with a seeming Avidity, and chancing to light upon the Eastern Story of Carazan, the Merchant of Bagdat, he confessed himself delighted with the Moral which it inculcates, and amazed at his Warmth and Sublimity of Imagination."

When Murply took leave of his readers in the last issue of the Gray's-Inn lourmal, he wrote what appears to be a final glancing reference to the Adventurer:

Besides, why may not a person rather chuse an Air of bold Negligence, than the obscure Diligence of Pedants, and Writers of affected Phraseology? For my Part, I have always thought an easy Stile more eligible than a pompous Diction, lifted up by Metaphor, amplified by Epithet, and dignified by too frequent Insertions of the Latin Idiom. I am there- 
Governor of South Carolina, Hawkesworth's Almoran and Hamet. But, "in truth," he writes, "I cannot think Dr. H. by any means a first rate writer. His tastc in writing seems defective. See his poor Task in regard to Fables in ye 18th adventurer vol. the First." ${ }^{\text {"26 }}$ This kind of unfavorable reception of the Adventurer appears to be the exception among an otherwise enthusiastic group

When the library of Laurence Sterne was offered for sale in August of 1768, the Adventurer in four duodecimo volumes appears in the catalogue alongside copies of the Tatler, Spretator, and Guardian. ${ }^{27}$ We have no evidence of Stcrne's feeling about the Adventurer although we know that he particularly admired the Spectator. In 1764 he wrote to his beloved daughter, Lydia: "I have sent you the Spectator and other books, particularly Metastasio; but I beg my girl to read the former, and only make the latter her amusement." ${ }^{\text {"s }}$ It is reasonable to think that Sterne would also have admired the instructive entertainment of the Adventurer, especjally the sentimental fiction.

Mrs. Hester Mulso Chapone, as one might expect from a contributor, recommended the Adventurer in her widely popular Letters on the Improvement of the Mind, Addressed to a Young Lady, which was published first in 1773. She writes:

For the present, there are works, which, without assuming the solemn air of philosophy, will enlighten your mind on these subjects, and introduce instructions in an early dress: of this sort are many of the moral essays that have appeared in periodical papers-which, when excellent in their kind-as are the Spectators, Guardians, Ramblers and Adventurers-are particularly useful to young people, as they comprehend a great variety of subjects--introduce many ideas and observations that are new to them-and lead to a habit of reflecting on the characters and events that come before them in real life, which 1 consider as the best exercise of the understanding. ${ }^{20}$

James Beattie, the poet of The Minstrel, alludes to the Adventurer in a letter to Mrs. Elizabeth Montagu in 1775. He protests, as does his Bluestocking correspondent, against Hawkesworth's skeptical attitude towards divine Providence in his general introduction to the Voyages of Byron, Wallis, Carteret, and Cook (1773) and reveals a good knowledge of Hawkesworth's literary production. Beattie writes: "From the theory of pity, which he has given us somewhere in the 'Adventurer,' one would suspect that he was no enemy to the philosophy of Hobbes. However, I am disposed to impute all this rather to a vague way of thinking, than to any perversity of heart or understanding." 
References to the Adventurer which occur in letters during the period of its weekly publication indicate that the literate public was pleased with the paper. Miss Catherine Talbot and "Mrs." Elizabeth Carcer, former enthusiasts of the Rambler, showed in their corrcspondence an active interest in the Adventurer, supporting it and searching out contributors, Miss Talbot first mentions the Adventurer in a letter to Mrs. Carter of December 17, 1752; she "hopes mucl from it."' ${ }^{20}$ On January 29, 1753, she writes to say: "I like the Adventurers; we all like them exceedingly; and I fancy they will soon become very generally fashionable. There was not a fault that the most captious found in the Rambler that is not obviated in these papers. They do not abound in hard words, they are varicd with a thousand amusing stories, they touch with humour on the daily follies and peculiarities of the times." "In July of 1753 she writes again: "The Adventurers go on incomparably whenever some pert letter of the alphabet does not intrude, and even they are better than the every day papers of the World."' Not knowing the editorial policy, she seems in March to feel that the Adventurer has ceased publication for want of encouragement. "In vain," she writes, "have I, in every company, done honour to the Adventurer, by naming numbers of the most acknowledged taste, even in the fine world, who constantly read and admire them. Mr. Dodsley [publisher of the World] prevails, and the Adventurer will soon cease his delightful instructions." ${ }^{\text {"2:3 }}$ And Mrs. Carter shares her friend's vexation and writes: "What an idea must it give one of the public taste, to find such a Paper sunk for want of encouragement. To be sure the fine folks of this world are as sagacious in finding out the formidable genius of instruction, however beautifully disguised, and run away from it with as much horror as good people do from a cloven foot. 1 have been equally suecessful in my preachings." "': The circle in which these ladies moved cvidently owed a divided allegiance to the World and the Adventurer.

of readers.

Horace Walpole, from whose voluminous correspondence we might expect some reference to the Adventwer, is naturally silent. In contrast to the solemn Bluestockings, he is prepossessed in favor of the lighthearted World, to which he himself contributed. Gilbert West, on the other hand, who received from Hawkesworth the first fourteen numbers of the Adventurer in an effort to enlist his support, liked both the Adventurer and the World "very well" and was responsible for sending Richard Jago's poem for inclusion in the new journal. ${ }^{25}$

William Shenstone, writing to Thomas Percy in July of 1761, announces that he has received as a gift from Mrs. William Lytletton, the wife of the 
impressive to find the Aduentuter achieving a place among this class of the literate public.

In contrast to Burns' enthusiasm, Charles James Fox, the statesman, was remembered by the minor poet, Samuel Rogers, to have considered the $A d$ venturer "very poor." He found the World "far superior, and he had read it with pleasure." But this kind of response is generally uncommon throughout the eighteenth century. The favorable comments on the Adventarer in contemporary correspondence are, on the contrary, full and impressive. It is possible to conclude from these leters that the Adventurer was commonly talked about by important people in almost every rank of life, that it had become part of the edifying literature recommended for young people, and that, through private reading societies and circulating libraries, it had established a prominent place for itself among that group of "classical essays" often reprinted during the latter part of the eighteenth century and into the nineteenth century.

\section{Notes}

1. Richmond P. Bond, ed., Studies in the Early English Periodical (Chapel Hill: University of North Garolina Press, 1957), pp. 19-20.

2. Hugh Waller, The English Essay and Essayists (London, 1915), p. 133.

3. The Monthly Revieu, VII (November, 1752), 373.

4. The Life of Samuel Jo/rnson (Londout, 1787), p. 310.

5. Gerard Edward Jensen, ed., The Covent-Gatden Jourmal (New Haven: Yale University Press, 1915), I, 84-88. "LUN" is John Rich's stage name. See also Mitchell P. Wells, "Pantomine and Spectacle on the London Stage, 1714-1761," unpublished Ph.D. dissertation, University of North Carolina, 1934, pp. 88-93.

6. London Daily Advertiser, Friday, November 24, 1752.

7. Gentleman's Magazine, XXII, 521-25; 587.

8. Gray's.Inn lotwrnal (London, 1756), II, 5. The Cocon Tree at 64 St. James's St, becond only to White's as London's oldest elub, fourished until 1932; it was, of course, like White's, originally a seventeenth-century coffee house. Addisun, Sir John Fielding, Fox, and Gibbon were among those on the list of members. See Aytoun Ellis, The Penny Utwitersities. A History of the Coffec-Hotses (London: Secker and Warburg, 1956), Pp. 226-27.

9. Adventurer No. 122 (January 5, 1754).

10. Gray's-Imn Journal No. 65 (January 12, 1754).

11. Ibid., No. 66 (January 19, 1754). This anonymous correspondent was Thomas Fitzpatrick, according to Jesse Foot, The Life of Arthur Murphy, Esg. (London, 1811), p. 68.

12. Ibid., No, 53 (October 20, 1753).

13. Ibid., No, 102 (September 28, 1754).

14. Ibid.

15. Ibid., No. 104 (October 12, 1754).

16. Walter Graham, English Literary Periodicals (New York: Nelson, 1930), p. 210; Monthly Review, VII (November, 1752), 373-76; X (Malrcir, 1754), $189-92$.

17. London Magazine: XXI (1752), 519-20; 558-60; XXII (1753), 132-34; 188; 321-23; $330-31 ; 369-71 ; 474-75 ; 519.20 ; 566-68 ;$ XXIII $(1754), 21-24 ; 70.72 ; 123$. The numbers of the Adventurer included are: $3,11,37,46,67,71,50,99,107,114,121,133,140$. The 
Beattie's sympathetic attitude towards Hawkesworth, in the midst of public disfavor, doubtiess stems from his own acquaintance with him in London.

Clara Reeve, like Mrs. Chapone, also recommends the Adventurer among "Books for Young Ladies" included in The Progress of Romance, published in 1785. She admonished parents thus:

The Author . . . does not presume to direct such Parents and Guardians in the choice of books for youth, as are qualified to sclect them; but only to offer to those, who have not thought much upon the subject themselves, and those who commit the charge of education to athers; a list of such books as may be put into the hands of children with safety, and also with advantage. This list is confined to books in our own language, and is intended chiefly for the fernale sex. a $^{\text {at }}$

Both Mrs. Chapone and Miss Reeve secured for the Adventurer a firm place among that array of edifying literanure towards the end of the century.

It is Robert Burns who best testifies to the popularity of the Adventurer in the closing decades of the eighteenth century. In 1788, alluding to the Book of Proverbs, he writes: "He [Solomon] may be looked on as the 'Spectator' or 'Adventurer' of his day: and it is, indeed, surprising what a sameness has ever been in human nature." ${ }^{32}$ In 1790 praising the Lownger written by his Scots compatriot, Henry Mackenzie, Burns remarks: "You know my national prejudices. I have often read and admired the Spectator, Adventurer, Rambler, and World; but still with a certain regret, that they were so thoroughly and entirely English." ${ }^{n g}$ In 1791 he writes to a bookseller for a copy of the Adventurer; he planned to add it to a collection in a circulating library which he had formed in bis county and for which he deserves the chief credit for organization and management. ${ }^{34}$ This library, according to Burns, was intended "to store the minds of the lower classes with useful knowledge," and was expected to be of "very great consequence, both to them as individuals, and to society at large." "Wh "When the little society of subscribers broke up a few years later, the books were sold by auction among the members themselves. They had collected about one hundred and fifty volumes, among which was the copy of the Adventurer. "A peasant," wrote Burns, "who can read, and enjoy such books, is certainly a much superior being to his neighbor, who, perhaps, stalks beside his team, very little removed, except in shape, from the brutes he drives." ${ }^{\text {"t }}$ Aside from testifying to the Adventurer's general appeal in Scotland, the evidence would seem to point to that rapidly growing audience who, unable to buy books, formed reading societies or subscribed to circulating libraries. It is 


\section{A Late-Century Spectatorial Essayist and His Personae}

BY EdWARD P. WILLEY

Oxford M.A, Ereshly in hand, William Roberts embarked at age twentythree on the Grand Tour, returning late the same year to establish himself as household tutor to a young gentleman at Hastings. During the tutorial tenure, broken off after two years in order to begin reading law in late 1793, Roberts' leisure time was partially devoted to writing and editing the Looker-On, the last eighteenth-century essay journal directly in the Spectator line to enjoy a degree of success, The Looker-On together with Roberts' introductory essay for the collected editions provides an interesting source for examining the theories and practices of a late-century Spectatorial essayist concerning the employment of personae.

Most essay journals of the late century such as the Looker-On are organs of generally conservative cast, their editors voicing dismay at the apparent abandonment of moral and aesthetic values by the more popular periodic media. These editors sought an audience in an age of great journalistic expansion, founding their hopes upon a medium that still adhered, almost rigidly, to a set of genre characteristics established some seventy-five years earlier. In midcentury the cssay journal eased into an enlarged physical format more pleasing to the eye, but little else was altered. ${ }^{2}$ The reader of the Mirror or Looker-On might have turned more pages and rubbed his eyes less often than did the followers of $\mathrm{Mr}$. Spectator, but he consurned indigenous matter. "A completely new or individual literary manner was the last wish of the authors of essayserials. If they were not Tatlers, Spectators, and Guardians, they were nothing at all."

William Roberts set his personal standards for imitation clearly:

Rules insensibly form themselves upon his [Addison's] model, and the design of the great projector must lead all subsequent attempts. It is the description indeed of a liberal, as distinguished from a servile imitation, that it is studious only of the principle and spirit of its model; and, without straining the resemblance to a mechanical conformity, raises a likeness not discernible in the detail, but stamped upon the generality of the whole. . . . Ignorance of these rules, or inability to follow them, has been one of the causes of the common failures of attempts to copy the graces and urbanity of the Spectator. 
attack on Adventurer No. 88 occurs in volume XXIV (Fobruary, 1755), 80; the reply ocetrs in valume XXIV (March, 1755), 119-21).

18. Gentteman's Magazine: XXII (1752), 521-22; supplement, 601-103; XXIII (1753), $34-36 ; 81-83 ; 124-26 ; 173-75 ; 231-34 ; 272-75 ; 328-30,376-78 ; 421-23 ; 474-76 ; 515-17 ; 572-$ 74 ; supplement, 610-12; XXIV (1754), 29-32; 76-78; 118-19. The numbers of the $A d$. ventwrer included are: $5,10,23,30,38,46,52,61,69,81,90,100,108,114,86,121,132$, 140. The attack on Adventurer No. 91 occurs in volume XLVIIJ (June, 1778), 263-60.

19. Jensen, ed, The Covent-Garden loumal, I, 122.

20. At Scries of Letiers from Mrs. Elizabeth Carter and Miss Catherine Talbos, ed. Montague Pennington (London, 1819), 11, 9.10.

21. libid, $I, 1-3$.

22. Ibid, II, $19-20$.

23. Ibid., II, 43-44.

24. Ibid., 11,46 .

25. Elizabeth Montagu, the Queen of the Bhte-Stockings: Her Correspondence from 1720 to 7761 , ed. Enily J. Climenson (Londan, 1906), 11. 25.

26. The Letters of William Shenstone, ed. Marjoric Williams (Oxford: Blackwell, 1939), p. 583.

27. A Facsinile Reproduction of a Unique Catalogue ol Laturtuce Sterne's Library with a preface by Challes Whibley (London: James Trcgaskis, 1930), p. 59.

28. The Letters of Lautence Sterne, ed. R. Brimley Johnson (Landon: John Lane, 1927), p. 40.

29. Leters on the Improvement of the Mind (Philadelphia, 1786), pp. 124-25.

30. An Account of the Lite and Writings of James Beattie, ed. William Forbes (New York, 1806), p. 265. Beattie alludes to Adventarer No. 110. $101-4$.

31. The Progress of Romance, Facsimile Text Society, scries I, IV (New York, 1930),

32. The Letters of Robert Burns, ed. F. DeLancey Ferguson (Oxford, 1931), I, 177.

33. Ibid., II, 18.

34. Ibid, II, 52 .

35. Ibid., II, 89.

36. Ibid, II, 90.

37. Recollections of the Table-Talk of Samuel Rogers, ed. Alexander Dyce (New York, 1856), p. 96. 
eccentric utterance grows tiresome. Failure of such a voice is failure of editorial insight. ${ }^{9}$ Judgments become more complex when the critic is confronted by more durable eidola. A major question concerns the degree of separation that exists between the voice of the eidolon and that of the essayist.

If the editor consciously designs his eidolon as insulation between himself and the reader, then there are indeed two voices. Steele claims this function when he observes in the final Tatler paper that Bickerstaff has been able to speak "with a Freedom of Spirit that would have lost both its Beauty and Efficacy, had it been pretended to by Mr. Steele." Such separation of voices, necessitating a distinct development of eidolon personality, is the norm for the genre. Exceptions to this practice exist. An editor may offer an eidolon who speaks in a voice almost indistinguishable from his own. Such, argues Richard B. Schwartz, is the case of Dr. Jolunson, who has been widely attacked for failure to make clear the distinction between $\mathrm{Mr}$. Rambler and himself. And though Schwartz rightfully demands that Johnson's practice be judged on its merits rather than labeled an "artistic lapse" because it doesn't fit a rigid notion of genre decorum, he does agree that Johnson's practice is an exceptional one.

Recognizing genre practice which establishes intentional separation of author-eidolon voices, there is yet a problem. The critic may respond too readily to the voice of the author's persona and allow it to drown out that of the author himself. The "author" may be, in the case of an essay journal, many authors, but the stamp of the editor and principal authors will be in the eidolon. In the case of the Looker-On, William Roberts is himself responsible for ninety percent of the content; his personal voice cannot be muted. Through his literary creations "a man defines-not hides-himself. By reading them, we are put in tourch with him, not with a series of intermediaries. The nature of his communication may be subtle; his manner, devious. Ultimately, however, he is telling us the truth." to the author/editor's truth or purpose.

"As affording room for a great diversity of topic and instruction, and as a powerful agent of moral culture, Mr. Olive-Branch adopted the plan of a periodic paper; and the public are to assign him his portion of credit in the conduct of it," writes William Roberts concerning his eidolon." The Reverend Simon Olive-Branch is described early for the readets of the Looker-On. ${ }^{12}$ No. 1 opens with the observation, "I am an old man, whose best years have been employed less in the service than the survey of my fellow-creatures." ${ }^{18}$ About sixty years old, a bachelor, living with his aging mother in Northamptonshire, Parson Simon certainly belies the mode lamented by a fellow journalist who says that eidola are usually described at the outset with the false objective of exciting 
He then writes of several characteristics of the Spectator worthy of imitation, but stresses one practice as the single necessary foundation for all successful essay journals: the establishment of unity through use of an eidolon. Whenever essayists have set out without observing this rule, according to Roberts, "they have miscarried."

A mere succession of essays, not connected by any common design, and conspiring to no general effect, is accordingly all that they have produced; and for want of that characteristic colouring, which in some instances has made this sort of publication the history of the mind of a thoughful individual, whose character, insinuated through the work, has fixed the regards of the reader, there is a total failure of that collateral interest which carries one forwards from subject to subject with a superadded curiosity and delight. Something to organise the parts into correspondence, and to constitute a whole; some common attraction to a general design; touches of moral painting that produce a sort of portrait of the writer, and clothes him with a conciliating parental character, ... are, I think, among the essential requisites of this kind of composition; and a loose compilation of essays, having no cement or lining of this sort, must consequently fail of producing all this satisfaction in the reader's mind."

Many essay journalists shared Roberts' view to one degree or another. Variety of content had long been recognized as the nature of Spectatorial papers. "The most frequent difficulty, by which the authors of these petty composition are distressed," observes Dr. Johnson, "arises from the perpetual demand of novelty and change." A means of establishing some sense of continuity amidst this diversity was discovered early, and in fact gave definition to the parent journal of the genre. Steele's editorial genius birthed the prime eidolon, Istac Bickerstaff, whose character "provided the essential unity and proved the focal center of the complete journal-without such a masterful creation the Tatler would bave been very, very different and, it is likely, incapable of its great achievement." A "very, very different" Tatler implies a very, very different progeny.

The decision to use an eidolon, then, which to Roberts seems basic, does indeed appear basic to the genre, and Roberts' scorn of those who ignore this device is understandable. The decision to use an eidolon is one thing; the cmployment of the particular is something else. In order to insure general unity via a spokesman whose character can be "insinuated through the work," the editor must endow his eidolon with an identifiable voice. A feeble or 
Though Roberts' Simon Olive-Branch was not born to shock, titillate erotically, or otherwise disturb a conservative status quo morality-no breaking of sacred icons here-neither was he to be forbiddingly severe. In his first essay Simon announces his design "to devote four sheets of paper a week, to such as can be amused without the sacrifice of decency," and he promises to deliver his lessons in their "most palatable forms."18 But as his lessons offer models and formulas ethically inspired, advance religion and controlled sensibility as the foundation of virtue, and counsel personal restraint through adherence to codes of moderation, refiection, and truth, the "palatable forms" are marked by "less frequent use of ... [Mr. Spectator's 'fine raillery'] than some of his predecessors" manage. ${ }^{10}$ The modern reader may agree with the "sensible young lady in the neighlworhood of Corpus Christi College" who enjoyed Simon's essays but indicated a desire for "another merry one or two." And though Roberts did not sacrifice his seriousness of purpose in response to such pleas, he was a university man in his twenties and a professed admirer of the urbanity of Addison and Steele, which he wished to perpetuate in an age that was, he felt, conspicuously lacking in such literary polish. Therefore though Simon was not without personal charm, his generally sober voice had to be occasionally tempered by others.

A traditional means of advancing multiple personae in the essay journals is through the use of the club device, a convention considerably worn by midcentury and not fuliy exploited even by those who established its reputation in the Spectator. ${ }^{21}$ Roberts, however, can not dissociate the club device from the essay journal tradition and introluces in the Looker-On two clubs which offer him moderate personae relief. In essay No. 3 a society of temperate men is described. ${ }^{22}$ This single issue describes well the tenor of the group together with many particulars concerning its policies and membership. Simon OliveBranch is "perpetual president" of the society which meets weekly in a special room where papers are real and conversation exchanged anong sixteen men dedicated to the banishment of all noise and quarreling from their midst. Membership is restricted to gentlemen above fifty years who agree to honor the written statutes and submit to prescribed penalties for transgressions. Such noxious habits as toasting, singing, betting, "abuse of superlatives," whistling, pretended zeal, and cracking of whips are all to be banished. The room itself returns an echo for any noise above a certain level, and to "rouse the echo" brings automatic penalty. Only two members achieve any individual development, but the club and its membership do serve to lighten the tone whenever introduced. The device is not so obtrusive as to become mechanically inhibiting, yet it is developed to a point of ready recognition. 
curiosity." Failure to promote an eccentric spokesman shows that Roberts understands the design which best serves his purpose. Studies of the gente have showr that the ideal eidolon "should not steal the show through an unnecessarily complex personality" but "should achieve a delicate compromise between the specific figure of an individual and the shaded outlinc of an idea."15 The persona requires no novel dimension to insure reader identification; "it need only be neutral enough not to discourage what amounts to a natural impulse," for the reader is ready to "sympathize with any speaker who sounds calm and well intentioned."1e

Other biographical information concerning Simon is introduced, but litle to cause the reader to revise his initial impression. Since the death of his father, Simon's mother, whose counsel and good opinion he constantly solicits, has served as his constant governess. After leaving Oxford at age twenty-one Simon devoted some years to reading and reflection. Finally at age forty-five he took orders to please his mother, "who loved tranquillity, but not jnoccupation." Ten years later his mother purchased the Northamptonshire living where be has been firmly implanted for six years. Additional individual and family traits only enlarge upon the general impression. Roberts does alter Simon's status radically when he closes the journal's run. In his final number he describes the death of Madam Olive-Branch, who expires only after she has extracted from her son a solemn vow that he will marry within a twelve-month. And certainly no reader could be so dull as to suggest that Simon Olive-Branch without a mother and in search of a wife was fit to continue his public admonitions.

Thus stands Roberts' eidolon, the product of a matriarchal environment, an. educated, conservative parson with a "cast of good-humour which flows from inward complacency of mind, and not the heyday of animal spirits." "This low-church country parson was calculated to appeal to British conscrvatives, wary of the climate of social revolution and ecclesiastical reform. Five years following the inception of his plan, in preparing his introduction for the fourth edition of the Looker-On, Roberts is gratifed to think "that there is yet a party in the country which can relish the formal cut of Mr. Olive-Branch's morality." The success of the Looker-On, modest but positive, was grounded upon a direct moralizing tendency. Roberts' statement in No. 2, "I give up all pretensions to please minds without religion, sense, or sensibility, for to such there is no access" is no idle moralistic puffing or flattery of audience. He formulated ant editorial policy demanding that a serious tone prevail, sketched in an appropriate eidolon, and went to work. Thus with the Looker-On we inherit another essay journal that clearly exemplifies the relationship between the periodical eidolon and its audience. ${ }^{17}$ 
enveloping parent essay, create self-contained letter-essays, use the material as points of departure for Olive-Branch's exercise of whimsy, establish points of continuity by references forward or backward, or employ the letter merely as undisguised filler, patching out an essay whose principal subject becomes prematurely worn or exhausted. The common denominator is editorial expediency, and as a rule there is a persona at work.

One use of a letter type device stands out above all others in the Looker-On, and in several respects stands out within the genre. "Letter device" is not technically accurate for the material introduced by Simon in No. 8: a young man, Eugenio, entrusted to me "a little packet, which I afterwards found to contain many passages of his life, and some letters to his dear Amelia, which in the course of my papers, I shall give to the public." Sometimes introduced as Eugenio's or Amelia's letters, sometimes as excerpts from Eugenio's 'reflections,' but always with strong personae, ever-strengthening in identity, the packet device affords material in fifteen different essays, forming the bulk of these numbers in ten cases. ${ }^{20}$

After introducing Engenio variously in four essays, Roberts has Simon inform his readers in No. 43; "But why should I thus piece out the history of my friend? ... I will therefore lay it before my readers, with the advantages of a regular narration." He then launches "one of the longest stories in any essay serial." ${ }^{\text {"30 }}$ Plotted around the trials of a true man of feeling, particularly his ill-fated love for Amelia, and narrated primarily in first person through the persona of Eugenio, the story is chiefly characterized by an overt sensibility. It is neither better nor worse than the popular periodic fiction of the era, fiction so extensive and "bloodless" that it serves as a "phenomenon in the history of taste. ${ }^{\text {"at }}$ Mayo comments on this persona strategy when he remarks that unlike the narrative fiction in most essay journals, narrations such as that of Eugenio utilize heroes in tune with the idols of the novel reading audience, heroes designed to counterbalance the "conventional lucubrations" of the eidola "and give the series a modish quality, and something of the interest of a novel." Roberts the editor was unwilling to ignore this mass audience potential, ${ }^{38}$ and even though it would not appear to be the same audience sought by Roberts the moralist, this persona departure does nothing to undermine Simon OliveBrancl's credibility. Eugenio is none other than a fictional embodiment of the concept of an ethical man of feeling that Roberts celebrates as his cultural hero throughout many of the journal's most serious essays.

In 1792 a young, educated man who wished to disseminate entertaining moral propaganda sclected as his medium the essay journal. His journal mirrors the position of patriotic, religious, conservatively conditioned English- 
The second club is even more limited in its use. Simon informs his readers in No. 5 that his mother presides over "a little levee of the young and old of her own sex," and though it does congeal into a regular society, it is never really described beyond outline form. ${ }^{28}$ The group is useful in discussing such 'fermale' things as gossip, clothing, and distaff education, but any real persona relief must be credited to its president alone. In addition to presiding and giving the society's generally bland nature the advantage of her more rounded literary development, Madam Olive-Branch is introduced many times independent of her salon. Simon frequently mentions his mother, and her emergent character accounts for a cumulative enlargement of the Olive-Branch image of both mother and son. Her opinions and reflections afford Roberts a prominent persona other than bis eidolon, even if not a distinctively differing voice. ${ }^{24}$

If Roberts is unwilling to abandon the club device altogether, he does, after introducing two such groups, carefully curtail their development. He then comes to seek personae dimension elsewhere, and he discovers a source where others had also-in the use of the letter. Addison in Spectator No. 542 lists various editorial strategies concerning the letter, one of which is personae relief: "It gave me an Opportunity of introducing a great variety of Characters into my Work, which could not have been done, had I always written in the Person of the Spectator." Scholars studying the genre have confirmed the success of this strategy among Addison, Steele, and their followers. ${ }^{\text {at }}$ What one scholar observes regarding the genre at large applies even more emphatically when directed toward the seriously intentioned Simon Olive-Branch: "For the unrelieved voice of the eidolon, however lively, could not have sustained by itself the lighter tone of the periodical essay without producing after a time the effect of the more formal treatise or sermon."

The Looker-On uses the letter to the editor to about the same degree as do Addison and Steele, again showing Roberts' sensitivity to the nature of his model. ${ }^{27}$ How many of these letters are of Roberts' manufacture is subject for speculation, but study of their nature and Roberts' own assertions would suggest that he is responsible for from $65 \%$ to $90 \%$. Personae are individually identifable in most letters, sometimes gaining identity from beyond the letterin-hand, For example, Peter Pry, who writes three letters, develops a personality, and there is a letter apiece from Madam Olive-Branch and her friend, Miranda, and one from an Olive-Branch ancestor. The frequent shift in persona makes possible sudden, justifiable shifts in subject, style, and tone. Roberts can momentarily suspend his eidolon's control, and be insipid as Paridel, clever as the Projector, gauche as Martha Muscle, ingenuous as Prince Lee $\mathrm{Boo}^{28}$ or sentimental as Amelia. He can treat of matters germane to the 
10. Irvin Elurcnpreis, "Personae," in Litcrary Meaning and Augustan Volues (Charlottesville: University Press of Virginia, 1974), p. 57. E'henpreis's eritical examination of the personae concept does not address the essay journal directly, but his critical arguments afford an interesting perspective for students of the genre.

11. "Introduction," [p. 6].

12. The chief description is in the initial number; other major characterizations occur in Nos. 2, 5, 12, and 15 .

13. The reader of Nu. 1 thus has no doube that the Speczator is the prime model. Not only are the titjes synonymous, but Simon's opening statement echoes Mr. Spectator's. "Thus I live in the World, rather as a Spectator of Mankind, than as onc of the Species," even to the point of key alliteration.

14. Coutnery Spectutor, No. 2.

15. For these and other characteristics of the ideal see Richmond P. Bond, The Tatler: The Making of a Literary loumal, pp. 166-67, and "lsaite Bickerstaft, Esi.s" in Restoration and Lightemth-Century Literature, ed. Carroll Canden (Chicago: University of Chicago Press, 1963), pp, 113-14.

16. Ehrenpreis, p. 58.

17. See Robert Donald Spector, "The 'Connorsseur': a Study of the Functions of a P'ersona," in English Writers of the Eighteenth Century, ed. John H. Middendorf (Now York: Columbia University Press, 1971), pp. 10y-21. Spector shows how the etdolon's tune can directly affect a journal's suceess. Because Colmatn and Thornton did not fully conform to the alietates of the clinute of opition surrounding the Connoissear, their cidolon's voice was eventually stilled.

18. No. 7.

19. "Introduction," [p. 7].

20. Quoted lron a letter (n.d.) written to Roberts by his friend and former tutor, Thomas Burgess, in Arthur Roberts, The Lite, Letters, and Opinions of William Roberts, Esq. (London, 1.850), p. 23.

21. See Donald F. Bond, "Introduction," The Spectator" (Oxford: Clatendon Press, 1965), I, xxxit-xxxiri.

22. The socicty plays a major role in Nos. 3, 24, 30, 34, 40,67, 73, and 74. Minor use is made in cight other papers.

23. The levee is used prominenty in but four papers: Nos. 5, 51, 66, and 89. Minor use occurs in five other papers.

24. Her chief contributions are in Nos, $6,9,18,40,54,58,75,81$, and 92 .

25. See the concise statement in Richmond P. Bond, Neal Letrers to the Tatler and Spectator (Austin: Unversity of Texas Press, 1959), pp. 12-13. For a comprehentsive and convincing view of the practice see Willian Alfred Bauer, "The Letter Device in the Early English Essay Jutrnal," unpubl. Diss. University of North Carolina, 1970.

26. Bauer, p. 604. Bauer demonstrates not juse the breadth of letter usage within the genre, bot the aterige follness of its use within the individual journal, and in the journals of Addison and Steele not just as foler, but as material artistically integrated into the very essence of the genre characteristics. Those who ignored the use "were constrained to find substitutes or seriously risked lapsing into rigidity and dullness or topicality and evanescence" (p. 513).

27. Bauer, p. 219, states that Ietters constitute $11 \%$ of the Tatler content, $25 \%$ of the Spectator through No. 555 , and $24 \%$ of the Guardian. The figure for the Looker-On is $23 \%$, being comprised of 51 letters in 35 different essay numbers.

28. Not, as it might appear, a facetious invention; Prince Lee $B$ oo, son of a native king of one of the Pelew Istands, died in London in 1784 of smallpox. Roberts makes use of him as citizen of the world,

29. Nos. $8,12,18,27,43-50,65,69$, and 80 .

30. Mayo, $\mathrm{p}$. 135. The story continues for eight issues and over twenty-four thousand 
men during a time marked by ecclesiastical, civil, literary, and moral reform. 'Time and again the author addresses himself to such issues as deism versus orthodoxy, the ailing church, political ferment and the current Paine controversy, the rights of women, class leveling, false lcaning, and the anemic condition of contemporary literature. One of the greatest compliments to be paid the editor is that despite his personal fervency and the endorsement of motally cogent topics the journal does not sink of its own weight. If Robcrts keeps a reformer's eye on society, he also keeps an editor's cye on his Spectator.

It is the judicions adoption of genre characteristics that saves the Looker-On as belles lettres. Principal among these characteristics in Robcrts' own mind is the use of the eidolon and other attendant personae. In his cidolon Ruberts finds a means of imparting unty to his disparate topics while maintaining a perspective consistent with the general persuasions of the journal. The LookerOn-its editorial bias and intended audience clearly stamped, its editor's use of eidolon, clubs, letters, and first person narrative fiction sustained throughout the run-offers a particularly interesting source for examining the function and design of the personae within the genre of the essay journal.

\section{Notes}

1. No. 1 (10 March 1792)-No. 86 (21 December 1793). Extended to 89 nos. in the 1794 collected edition, athl to 92 nos. in the 1795 edition. Subsequently published in America, 1796. London in 1797 and 1808, and included by Alexander Chilmets in his British Essayises begioning with the 1808 cdition.

2. George P. Winship, Jr, "The Printing History of the World," in Siudies in the Early English Pcriodichl, ed. Richmond P. Bond (Chapel Hill: University of North Carolina Press, 1957), pp. 185-86. Though the format was enlarged, the average length of the essay remained stable throughout the century: see Robert D. Mayo, The" English Novel in the Magatines: 1740-1815 (Evanston: Northwestern University Press, 1962), p. 74 .

3. Mryo, p. 73.

4. "Introduction," [p. 3]. Roberts' essay of introduction first appeared in the 1797 London edition. All references to the essiy are to Chalmers" British Essayists as the most accessible text. In Chalmers the essay prints out to sixteen pages.

5. "Introduction," [pp.4-5].

6. Ramble", No. 184. Roberts echues the complainc: "Ir is one of the hardest conditions of my undertaking, that I must bend my thoughts 50 many various ways for the entertainment of the public": Looker-On. No. 7. All references to the Looker-On are hased on the 1797 edition. The numbering sequence is that of the 1797 edition and subsequent editions. The essay sequence after No. 30 differs among the folio, 1794, and 1795 cditions.

7. Richmond P. Rond, The Tatler: The Making of a Literary lournal (Cambridge: Harvard University Press, 1971), p. 8.

8. These inferior voices caused George Saintsbury to state that the chief hindrance to the reader's pleasure is artributable to "the clumsy intrusions of those unlucky eidola whom convention required." The Peace of the Atrustan (Loudon, 1916), p. 18.

9. "Johnson's 'Mr. Rambler' and the Periodic Tradition," Genre, 7 (1974), 196-204. 
words. Printed in staggered sequence in folio, it appears uninterrupted in collected editions.

31. Mayo, p. 2. "It is largely the result," Mayo continues, "of the rapid growth of a new reading audience which was naive, sentimental, and eager for the airs of gentility."

32. P. 137. Mayo is referring to the Looker-On and the later imitative Literary Leisure (1799-1800).

33. The Eugenio story must have had some success with this audience, for it was serialized complete in two American periodicals: Massachusetts Magazine in seven parts (May 1796-November 1796); Philadelphia Minerva in fourteen parts (28 October 1797. 27 January 1798). It was also published in separate book format as the Story of Eugenio and Amelia: or, the Vicissitudes of Life (Worcester, Mass., 1798). 


\section{List of Contributors}

Giles Barler is Director of the Taylor Institution Library at Oxford.

Edward A. Bloom is Professor of English at Brown University; Lillian D. Bloom, his wife, is Professor of English at Rhode Island College. Both of them have published extensively, both independently and in collaboration. He has been a Fellow of the Huntington Library and a Guggenheim Fellow.

Fredson Bowers is Eneritus Linden Kent Prolessor of English at the University of Virginia. He is a distinguislyed scholar and critic, having published extensively in many areas including bibliography, textual criticism, and Shakespeare.

Oliver Ferguson is Professor and Head of the Department of English at Duke University. He has been a Cuggenheim Fellow and has published extensively, particularly on Jonathan Swift and Oliver Goldsinith.

James E. Gill, Associate Professor of English at the University of Tennessee, has been a Fellow of the Council of Southern Universities and has published several essays on theriophily and Jonathan Swift.

Philip Mahone Griffith is Professor of English at the Lniversity of Tulsa. His publications include studies of periodicals, eighteenth century Shakespearean criticism, Richardson, Johnson, Smollett, and Swift.

Robert Halsband, Professor of English at the University of Illinois-Urbana, is the author of numerous books and articles on a varicty of aspects of eighteenth century literature including biographies of Lord Hervey and Lady Mary Wortley Montagu and an edition of Lady Mary's letters.

Lodwick, Hartley, Professor Emeritus of English at North Carolina State University, has published numcrous books and articles including criticism, biography, and bibliography concerning such diverse figures as Laurence Sterne, William Cowper, and Katherine Anne Porter.

Matthew Hodgart is Professor of English, Concordia University, Montreal. He is the author of an important study of the eighth volume of the Spectator.

Annibel Jenkins, Associate Professor of English, Georgia Jnstitute of Technology, is the author of a book on Nicholas Rowe and of articles on Renaissance, Eighteenth Century, and Modern literature.

Wilmarth S. Lewis holds numerous honorary degrees including those from Yale University, Brown University, the University of Melbourne, and Cambridge University. He is internationally renowned as a collector of works associated with Horace Walpole and as editor or author of numerous works by or about Walpole.

Gilbert D. McEwen is Professor of English at Whittier College, California. He has hand research grants from the Danforth Foundation, the Huntington Library, and the American Pbilosophical Society and has published an inportant book-length study of John Dunton's Athenian Mercury.

Henry L. Snyder, Professor of History and Dean of Research at the University of Kanssas, is the author of numerous studies of the interrelationship of politics and the press in Augustin England. 
Robert B. White, Jr., is Professor and Assistant Head of the English Department at North Carolina State University. He has published studies of such diverse subjects as Chaucer's Canterbury Tales, Paradise Lost, and the periodic press.

Edward Willey is Assistant Professor of English at Clemson University in South Carolina.

Professors Gill, Griffith, Jenkins, White, and Willey were all graduate students under Professor Bond's direction. 


\section{LNIVERSITY OF KANSAS PUBLICATIONS Library Series \\ Editor. JAMTS HeLYar}

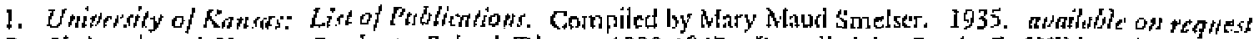

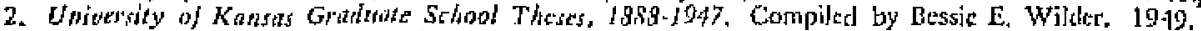

3. Two Anguston Bookseliers: Joht Dumon and Edmond Curli, by Peler Murray Hill. 1958. \$1.00

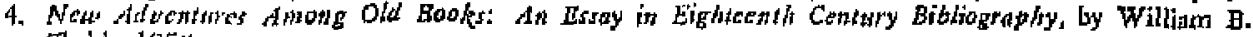
Tald. 1958.

5. Cutalogues of Rare Dooks: A Chapter in Bibliogrophicol History, hy Archer Taylor. 1958.

6. What Kitd of a Buriness is Thist Heminiscences of the Dook 7rade and Brok Collectors, by Jacob Zcitlin, 1959 .

7. The billiographical Way. by Fredson Buwers. 1959.

8. A Mibliography of English Imprists of Denmark, by P. M. Miccheld, 1969.

9. On we Ewrting of His Library and On Medical Travel, by Thomas Bartholin, translited by Charles D. O'Malley. igGl.

10. A Rikhograthy of the Frank $E$. Mcluin Collection of Nomphlat of the Fiench Resolution in the

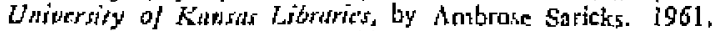

11. Observations on Patrer as Evidene, by Alen H. Senenson. 1961.

2 vols, 57,50

12. Unimersity of Kansas Gradante Schonl 7/esses, 1948-1958. Compited by Bessie E. Wilder. 1961. \$2.50

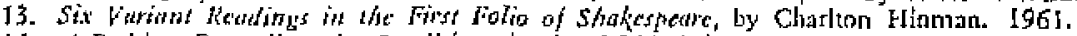

$\$ 1.50$

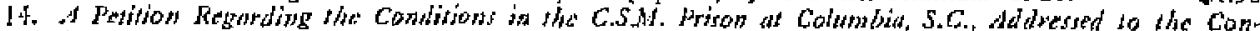

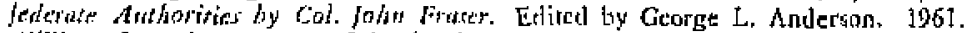

15. Tillion Dammial: Setman-Sciemist, by lostph C. Stipman. 1962.

$\$ 2.50$

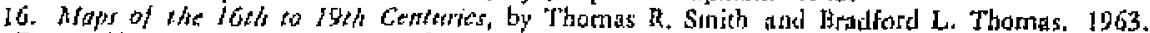

17. Loolinge at an Early Map, by R. A. Sticlion, 1965.

18. A Bibliogrotthy of lames jotce Sindits, by Robert H. Dening. 1963.

19. Nass of Corta Rica, by Albert 1H. Palmerice. 1965.

20. A Chechlist of Linneama, 1735-11355, by Terrence Willians, 1964.

$\$ 1.50$

21. Internationel Bibliograply of Verctovion Mass colited by Arnerica, 1965.

22. Fow Gemtwies of Shakespeare Pabliotrion, by Giles E. Dawson. 1964.

23. A Grile to the sist pu 'T'tung K'an, by Karl Lo. 1965.

25. Cenored: Books and heir Risht to Lite by Elmer Gertz. 1965.

26. Inesudtional bibliography of Vegtation Mapt, adied by A. W. Küchler. Volume 2: Eurape. 1966.


Thomes R. Burkemin. 1966.

29. A Biblography of t7h Centeres German th Holstern, compiled by P. M. Mitchefi. Volumes J-2, ighe.

30. Nitke's last yeur by Geose $C$ schoolfold 1909 .

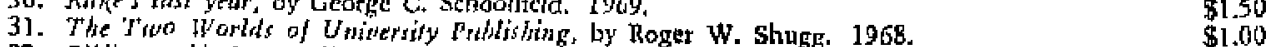

32. Eihiographioal Comithitions, 1. 1969 .

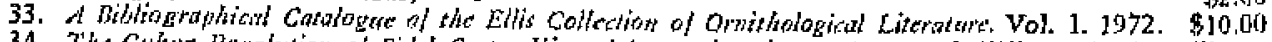

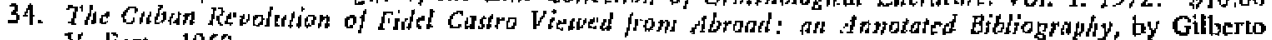
V. Fort. 1909.

35. Growh and Change int the Early English Press, by Richnond P. Hond. 1969.

$\$ 3.00$

36. Intermational Billiom Arnerica, and World Maps. 1970.

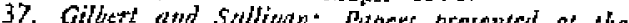

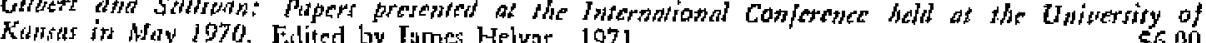

8. Wrathe Helited by James Hejyar. 1971.

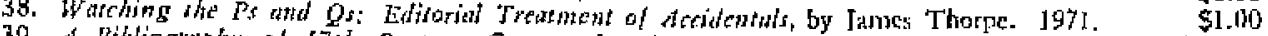

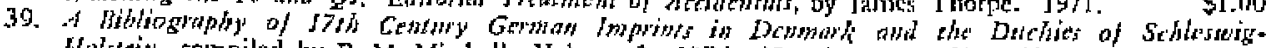
Holsetw, compiled by P. M. Mitcluell. Volume 3. 1976. (Supplement to No. 28)

40. Dibliamplisal Contributian., 2. 1976.

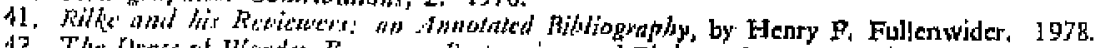

$\$ 2.00$

5,40


P. Bond. Eilited by Roberi ls. White, Jr, 1978.

$\$ 12,00$

13. A Crition Bibliography of Dr. Hewy Sachruerdl, by F. F. Madan. Edited ly W. A. Spedk. 1978.

$\$ 15.00$

- Titles narked will an asterisk are now in shert suphly, and are normally only avititble to com-

plete the files of justitutians maintaining exchange agreenents with Jue Univrtsily of Kanses Liloraries.

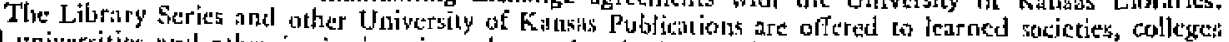

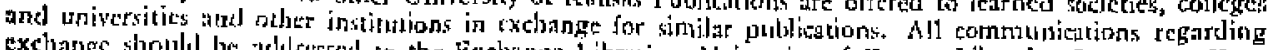

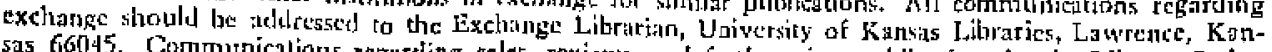
sas 66015. Communications regureding sales, reviçws, and fortheoming publications in the Liturary Series,

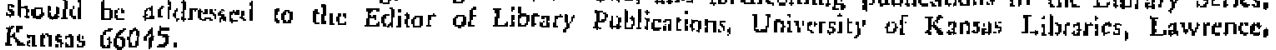

